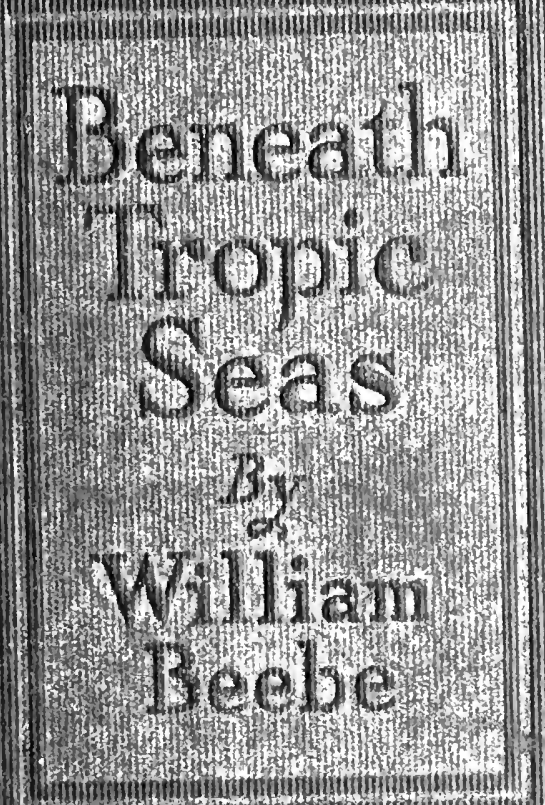



$1+1 /<$ 
$B$

$\bar{z}$

019 


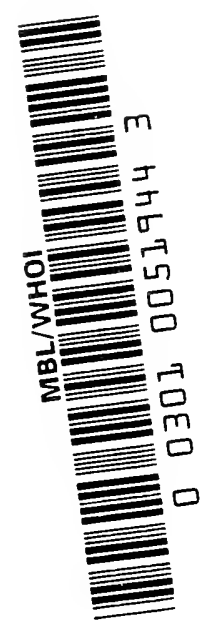

R/V Chraly LIBRARY 


BOOKS BY WILLIAM BEEBE

TWO BIRD-LOVERS IN MEXICO

Houghton, Mifflin Co.-

THE BIRD

Henry Holt and Co.-1906

THE LOG OF THE SUN

Henry Holt and Co.-rgob

OUR SEARCH FOR A WILDERNESS

Henry Holt and Co.- 1910

TROPICAL WILD LIFE

New York Zoological Society-I9I7

JUNGLE PEACE

Henry Holt and Co.-IgIS

EDGE OF THE JUNGLE

Henry Holt and Co.-192I

A MONOGRAPH OF THE PHEASANTS

H. F. Witherby and Co.-1918-1922

GALÁPAGOS: WORLD'S END

G. P. Putnam's Sons-rg24

JUNGLE DAYS

G. P. Putnam's Sons-1925

THE ARCTURUS ADVENTURE

G. P. Putnam's Sons- 1926

PHEASANTS: THEIR LIVES AND HOMES

Doubleday, Page E Co. -1926

PHEASANT JUNGLES

G. P. Putnam's Sons-1927

BENEATH TROPIC SEAS

G. P. Putnam's Sons-1928 


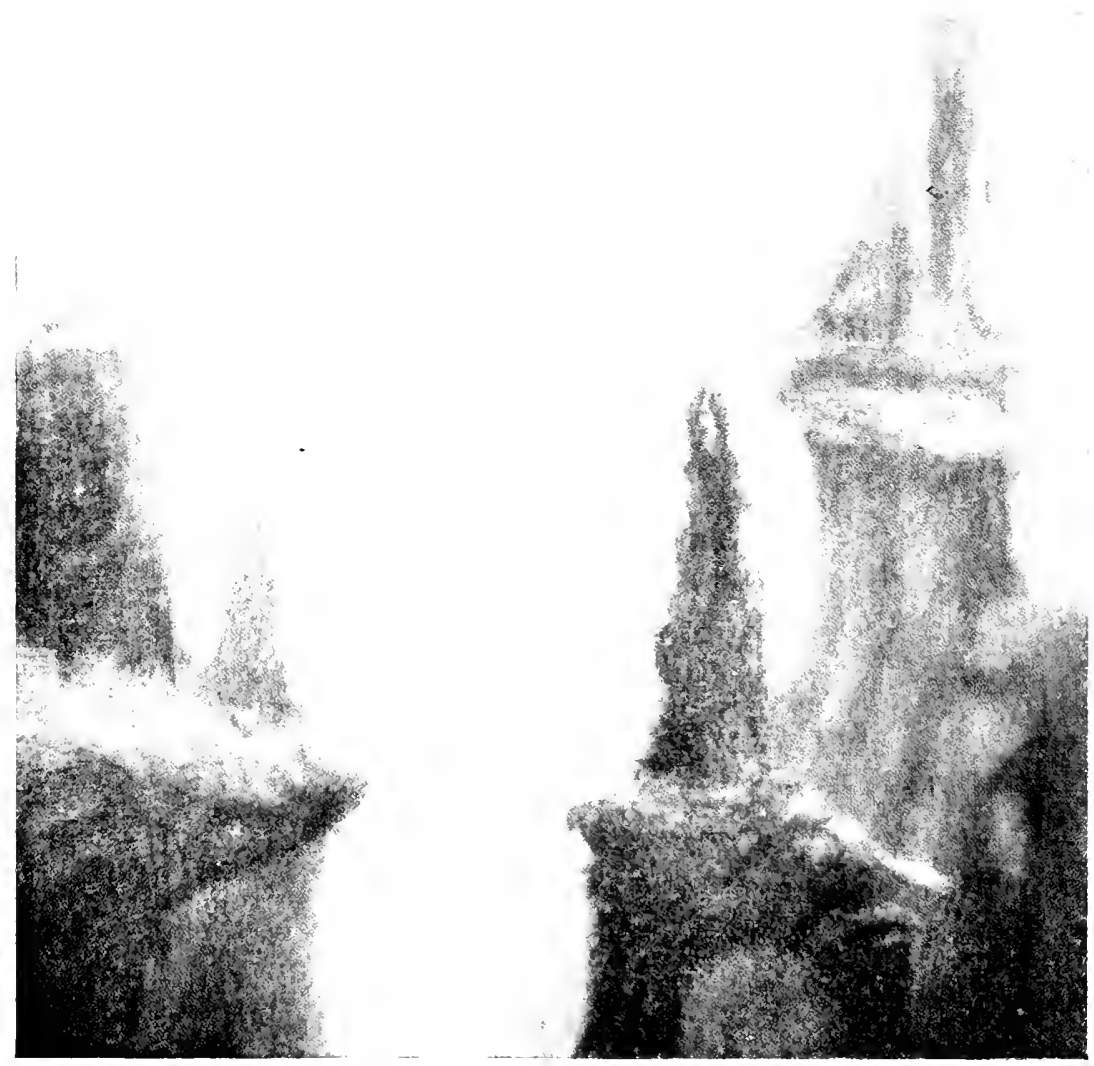


\section{No-Man`s-Land Five Fathoms Down}

Painted by Zarh Pritchard many feet beneath the water on a coral reef in the Lagoon of Maraa, Tahiti 


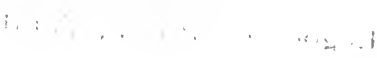

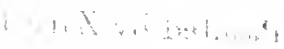

$\because 1, \cdots:$

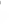




\title{
BENEATH TROPIC SEAS
}

A RECORD OF DIVING AMONG THE CORAL REEFS OF HAITI

\author{
BY \\ WILLIAM BEEBE, Sc.D. \\ Director of the Department of Tropical Research \\ of the New York Zoölogical Society
}

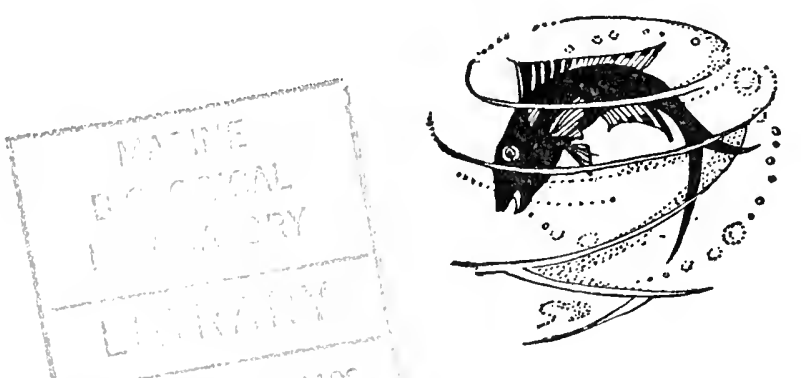

WITH SIXTY ILLUSTRATIONS

G. P. PUTNAM'S SONS

NEW YORK - LONDON

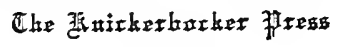

1928

R/V Cratani LIBRARY 


\section{BENEATH TROPIC SEAS}

Copyright, 1928

by

William Beebe

First printing, September, I 928

Second printing, September, 1928

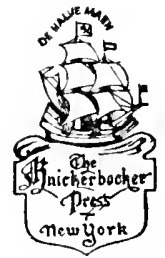

Made in the United States of America 
To

ELSWYTH THANE 


$$
\text { . }
$$




\section{PREFACE}

The Tenth Expedition of the Department of Tropical Research of the New York Zoölogical Society was made possible by generous contributions from members of the Society. Its work was carried on in the Bay of Port-au-Prince, Haiti, where we studied the coral reefs and the fishes.

The final results will materialize in a series of scientific papers, which, it is hoped, will add something to our knowledge of the life of the sea. These will hardly be read by the general public, hence I have chosen a few high-lights of the expedition and crystallized them into these thirteen chapters.

As far as the actual experiences are concerned, any reader of this volume may duplicate them. The diving helmet, hose and pump, with which all the research was done, are as inexpensive as they are simple in operation.

I have had so many inquiries as to the inception and cost and operation of a scientific expedition, that I have thought it worth while to add several appendices, giving, in brief form, the gist of this information.

W. B. 



\section{CONTENTS}

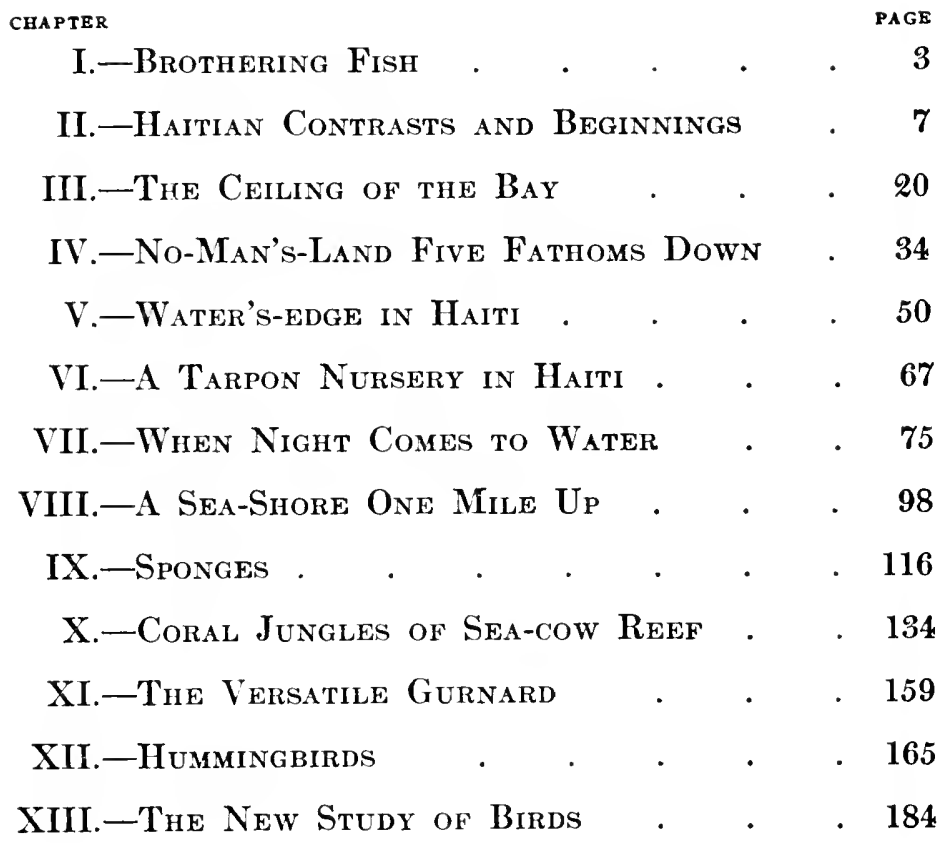

\section{APPENDICES}

A.-The Haitian Expedition $\quad$. $\quad$. $\quad 199$

B.-Outfit of the Haitian Expedition · 205

C.-Methods in Submarine Photography, by John Tee-Van . . . . . . 211 vii 


\section{CONTENTS}

PAGE

D. - List of Haitian Birds Observed • . 216

E.-Families and Number of Species of Haitian Fish Collected . . . 225

F.-Translation of "The Larva of the East Indian TARPON" .

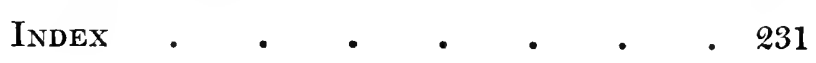

viii 


\section{ILLUSTRATIONS}

FACING
PAGE

No-Man's-Land Five Fationos Down Frontispiece

Painted by Zarh Pritchard many feet beneath the water on a coral reef in the Lagoon of Maraa, Tahiti.

Map of Haiti, Showing the Localities Mentioned

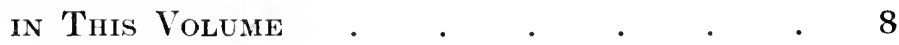

The Lieutenant and the Shore of Haiti from Five Hundred Feet Elevation . . . 14

Tents on the Deck of tie Lieutenant . . 15

Laboratory Tent on tile Schooner . . . 15

Our Schooner, the Lieutenant, Anciored Near the Shore Aт Bizoton . . . . . 22

A Swarm of Thimble Jellies, Linuche unguiculata 23

Five Sahald, Surface Jellies, Enlarged 7 Times 23

Puffers, Diodon hystrix, Inflated and Deflated 26

Elk-horn Coral near Surface. . . . 27

Enlargement from cinema film.

Giant Jelly-fish from the Side • . . 30

Giant Jelly-fish from Below, Showing Some of the Three Hundred and Fifty Fish Living INSIDE . . . . . . . . 30 ix 


\section{ILLUSTRATIONS}

Airplane View, One Mile Up, of the Lieutenant, Haitian Shore at Bizoton and the Coral Reefs

Sand Cay and Beacon from Motor Boat

Sand Cay as Seen from Airplane, One Mile Up

The Author on a Coral Reef, Writing on a Zinc Pad with lead Pencil ..$\quad$. $\quad . \quad$. 39

Tube-living Sea-worm . . . . . . 44

Yellow and Brown Sea-worms, Spirobranchus tricornis, Growing in Coral, Showing Motherof-pearl Trap-doors, Ready to be Closed Down

Coral Reef, Three Fathoms Down, Showing Corals and Gorgonias

Enlargement of cinema film.

Coral Reef, Four Fathoms Down, with Coral, Sea-plumes, Gorgonias and Wrasse . $\quad 58$ Enlargement of cinema film.

Water's Edge at Bizoton

Sand Anemones, Parent and Young, Asteractis

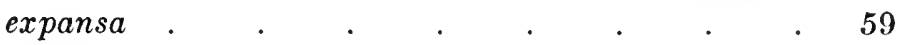

Seining in the Sulphur Lagoons of Source

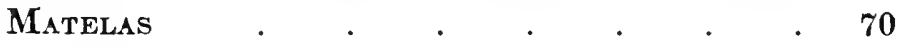

Young Tarpon Seined at Source Matelas • 71

Three-inch Tarpon in an Aquarium on the

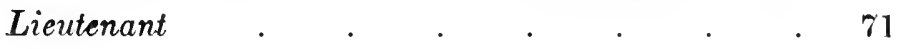

Forty Pound Tarpon Caught by Haitian Fishermen . . . . . . . . . . 74

Submerged Light at Gangway of the Schooner 75 


\section{ILLUSTRATIONS}

PACING

PAGE

Four-inch Quad Jelly-Fish, Tamoya haplonema, with Twelve Live Fish which Were Living INSIDE IT

86

Leptocephalus Stage of Bone-fish, Albula vulpes 87

Bregmaceros, a Deep-Sea Fish Caught at SubMERGED LIGHT

87

Young Batfisir, Halieutichthys, Taken at the Surface at Night . . . . . . . 94

Young Flounder which Floats on the Surface at Night by Curving its Body into a Cup-shape

Photograph of Plankton, Collected at 8 P.m. April 30, 1927, at Submerged Light . $\quad 95$

Christophe's Castle $\quad . \quad$. $\quad . \quad$. 114

Giant Sponge from Lamentin Reef . . . 115

Surface Grating of Giant Sponge • • . 115

Section of Giant Sponge Showing Snappingshrimps and Crabs Living in the Internal

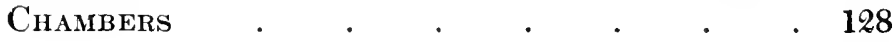

Snapping-shrmps from Giant Sponge • . 128

Cardinal Sponge-Fisit, Amia, in Bottom of

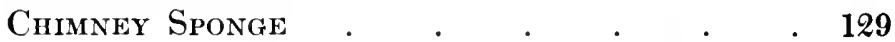

Cardinal Sponge-fisir, Showing Generalized Pigmentation, and Nocturnal Character of

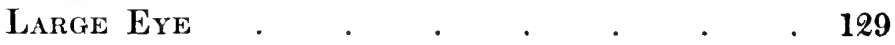

Williali Beebe after Ascent from Sixty-foot Dive at the Side of Schooner . . . 136

Reconstructed View of Soft Ooze and Seacucumbers Collected Ten Fathoms Down . 136 


\section{ILLUSTRATIONS}

Barracuda Swimming Past the Camera . . 137 Enlargement of cinema film.

Coral Cave Several Fathoms Down, Showing Purple Sea-fans, Gorgonias, Coral-heads, and Grey SNappers . . . . . . . 137 Enlargement of cinema film.

Slender Trigger-fish, Alutera . . . . 152

Tirree Aluteras Camouflaged as Blades of Thalassia Eel-grass . . . . . 152

Head of Rock-fish, Scorpcona. A Common Tenant of Haitian Coral Reefs . . . . 153

Front View of Batfish, Ogcocephalus, Showing Sensory Tentacle and Leg-like Fins . . 153

Horse-fish, Eques, which Lives in Coral Caves, and has a Most Remarkable Pattern . . 156

Hermit-crab, in a Living Cloak of Six Anemones 156

Calappa Crab, with Claws Dove-tailed Together in Front of the Body . . . . . 157

Calappa Crab, with the Claws Raised • • 157

Note their resemblance to the heads of fowl.

Young Flying Gurnard, Cephalacanthus volitans, Taken at Light, Showing the Ventral Fins Functioning as Legs . . . . . . 164

Flying Gurnard, Showing the Pectoral Fins Drvided into Two Parts, the Anterior Portion Used as Hands, the Posterior as Wings.

Brass Submarine Camera Box Open, Silowing Camera . . . . . . . . . 165 xii 


\section{ILLUSTRATIONS}

FACING

PAGE

Submarine Camera Box Closed, Ready for

SubMersion $. \quad . \quad . \quad . \quad . \quad . \quad . \quad 165$

Floyd Crosby Taking Motion Pictures of a Haitian Coral Reef . . . . . 214

Nesting Colony of Black-headed Weaver, Hyphanthornis c. cucullatus, Near the Flying Field, Port-au-Prince . . . . . 215

This bird has been imported from Africa.

Leptocephalus Larva of East Indan Tarpon, Megalops cyprinoides. a, Vent; $s$, Swmi-Bladder; $v$, Ventral Fins. (After van Kampen) . . 229

All photographs, unless otherwise noted, taken by Floyd Crosby; Frontispiece painted by Zarh Pritchard; lower illustration facing page 156 painted by Helen Tee-Van; illustrations facing pages 152 and 164 drawn by Edith Thane; Photographs facing pages 14, 31, lower 38, and 114 by Lieutenant Hayne Boyden; photograph facing page 95 by M. G. Schneckenberger under the direction of Dr. C. J. Fish; and illustrations facing pages 8,165 and 214 by John Tee-Van. 

. 


\section{BENEATH TROPIC SEAS}




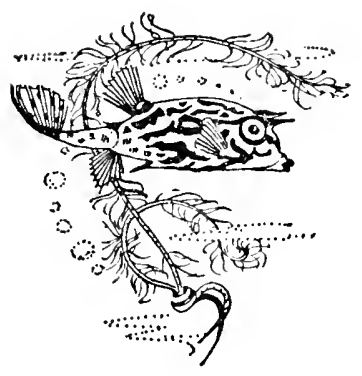




\section{Beneath Tropic Seas}

\section{CHAPTER I}

\section{BROTHERING FISH}

You are standing on a metal ladder in water up to your neck. Something round and heavy is slipped gently over your head, and a metal helmet rests upon your shoulders. Thus were the knights of old helmed by their squires for the grim business of war. Instead of a slotted vizor, however, you find two large frames of glass before your eyes. Turning your head you see emerald waves breaking upon the distant beach of ivory, backed by feathery palms waving in the sunlight against a sky of pure azure.

You wave good-by to your grinning friend at the pump, and slowly descend, climbing down step by step. For a brief space of time the palms and the beach show intermittently through waves which are now breaking over your very face. Then the world changes. There is no more harsh sunlight, but delicate blue-greens with a fluttering of shadows everywhere. Huge pink and orange growths rise on all sides-you know they are living corals, just as you know that the perfect clouds 


\section{BENEATH TROPIC SEAS}

in the sky visible in the earliest light of dawn from Darjeeling are not clouds, but the snow peaks of the distant Himalayas. The first little people of this strange realm greet you-a quartet of swimming rainbows-four, gorgeously tinted fish who rush up and peer in at you. You reach out for them, and they vanish.

Now your feet touch ground and you walk slowly about on the cleanest white sand in the world. An ostrich feather of a sea-plume as tall as yourself sweeps against you; it is royal purple and might well be some weird fern from Mars. On a mound of sand you gently seat yourself, sand-colored crabs and small fish skittering just out of the way. You lean against a fret-work of purest marble while at your elbow is a rounded table of lapis lazuli on which are blossoming three flowersflowers unearthly and which lean toward you of their own free will. Their petals are resplendent in hues of gold and malachite, and are fluted and fringed like some rare and unknown orchid. You reach forward to pluck one, and, faster than the eye can follow, the blossoms disappear beneath the fur of lapis velvet from which they seemed to sprout.

Dozens of fishes, all strange, all graceful and beautiful, play about you, nibbling at the coral, rushing toward the sponge which you have lifted from its place, hoping for some disturbed titbit. When you sit quietly they gather closer, and peer in through the glass at you again and again. Their absurd mouths forever open and close, and if you 


\section{BROTHERING FISH}

are a good lip-reader you cannot fail to decipher the syllables which seem to issue in watery waves. They say, "Oh! Oh! Brother! Brother! Oh! Oh!" And you answer them in kind, speaking from the safe, dry, airy room of your helmet. They are so friendly, so curious, so utterly unlike the nervous, useless-lived inmates of our aquariums.

Your attention swings from wonders to marvels and back again. You begin to say things to yourself, gasps of surprise, inarticulate sounds of awe, you are troubled with a terrible sense of loss that (as the case may be) twenty, thirty or fifty years of your life have passed and gone without your knowing of the ease of entry into this new world. Are you under water? There is no sense of wetness, the air you breathe is, if anything, better than that in the motor-boat rocking overhead. You hold up your hand and see little washerwoman's wrinkles on the soles of your fingers and you realize you are where you are. A great blue enameled fish glides past, then suddenly stands straight upon his head and mumbles something; a skein of fairy lace drifts against your helmet; to your friends in the boat it is merely a school of jelly-fish.

Only a moment has passed since you left the world overhead, or was it many hours? A gentle tug comes along the hose and you resent this reminder of an existence which you had almost forgotten. But you rise and half walk, half float to the swaying ladder, and regretfully mount it. 


\section{BENEATH TROPIC SEAS}

You find that you have been down forty minutes and another impatient adventurer is waiting to take your place. You had planned to tell the others all about it, but you suddenly find yourself wordless. You exclaim something bromidic which sounds like Marvellous! Great! Wonderful! then relapse futilely into silence and look helplessly into the distance where the emerald waves still break and the palms wave as if fairyland had not intervened in your life since you saw them last.

All I ask of each reader is this,-Don't die without having borrowed, stolen, purchased or made a helmet of sorts, to glimpse for yourself this new world. Books, aquaria and glass-bottomed boats are, to such an experience, only what a time-table is to an actual tour, or what a dried, dusty bit of coral in the what-not of the best parlor is to this unsuspected realm of gorgeous life and color existing with us today on the self-same planet Earth. 


\section{CHAPTER II}

\section{HAITIAN CONTRASTS AND BEGINNINGS}

For two weeks I have been doing advanced outpost duty in Haiti for the Tenth Expedition of the New York Zoölogical Society. Fish are the dominant reason for my choosing this part of the world for a winter of work, but my four-masted schooner, the Lieutenant, is still beating its way southward from New York with all my diving-helmets and nets, cameras and microscopes on board, so up to now my part has been that of the soldiers in Kim's dream who "go ahead to make all ready."

I have always felt that the chief joy in life is contrast, and here there is nothing else.

From the moment of my landing I have been the recipient of the most perfect hospitality at the home of the American High Commissioner, General John H. Russell, and Mrs. Russell. Here is the epitome of culture, of social grace, and the never ceasing consciousness of terrific responsibility in governing this great island,-tempering the fires of human volcanoes with justice, good humor, and restraint. Contrast demands that I ask you to picture my contentment and happiness in working in a paradise of a guest annex, with mangoes, cocoa- 


\section{BENEATH TROPIC SEAS}

nuts, oranges, and bread-fruit within reach from the verandah, with a lofty range of cloud-flecked mountains rising just at the back, and the great emerald and cobalt Gulf of Gonave before me; with books and swimming pools at hand, and all the other tools for the joy of mind and body.

And now let us walk down the rose-bordered path to the front gate and watch the unending stream of countryfolk coming into the city with their merchandise. Algernon Blackwood would enjoy them for they are centaurs of sorts-lowly ones, if you will-yet we cannot laugh at them for riding on asses - for that was the method of travel of a certain man of Galilee. If we wonder why there are only women centaurs the answer is, habit, for up to a year or two ago no countryman dared come to the city for fear of being shanghaied into the native army, without pay and with death imminent.

The first to pass is a finely-built woman, almost buried in great bundles of grass on her burro. Freed from her dirty calico gown, and with her facial character and carriage, she might be the wife of a Zulu chieftain. To her the alphabet is only hieroglyphics which unreasonably and endlessly besmirch good paper; politics, geography, styles, prohibition, worry, responsibility,-all these, to her mind, are not even nebulous. And yet it would be difficult for my excellent host or myself to match her in happiness and contentment. She has been two days and perhaps nights on the march; in the 


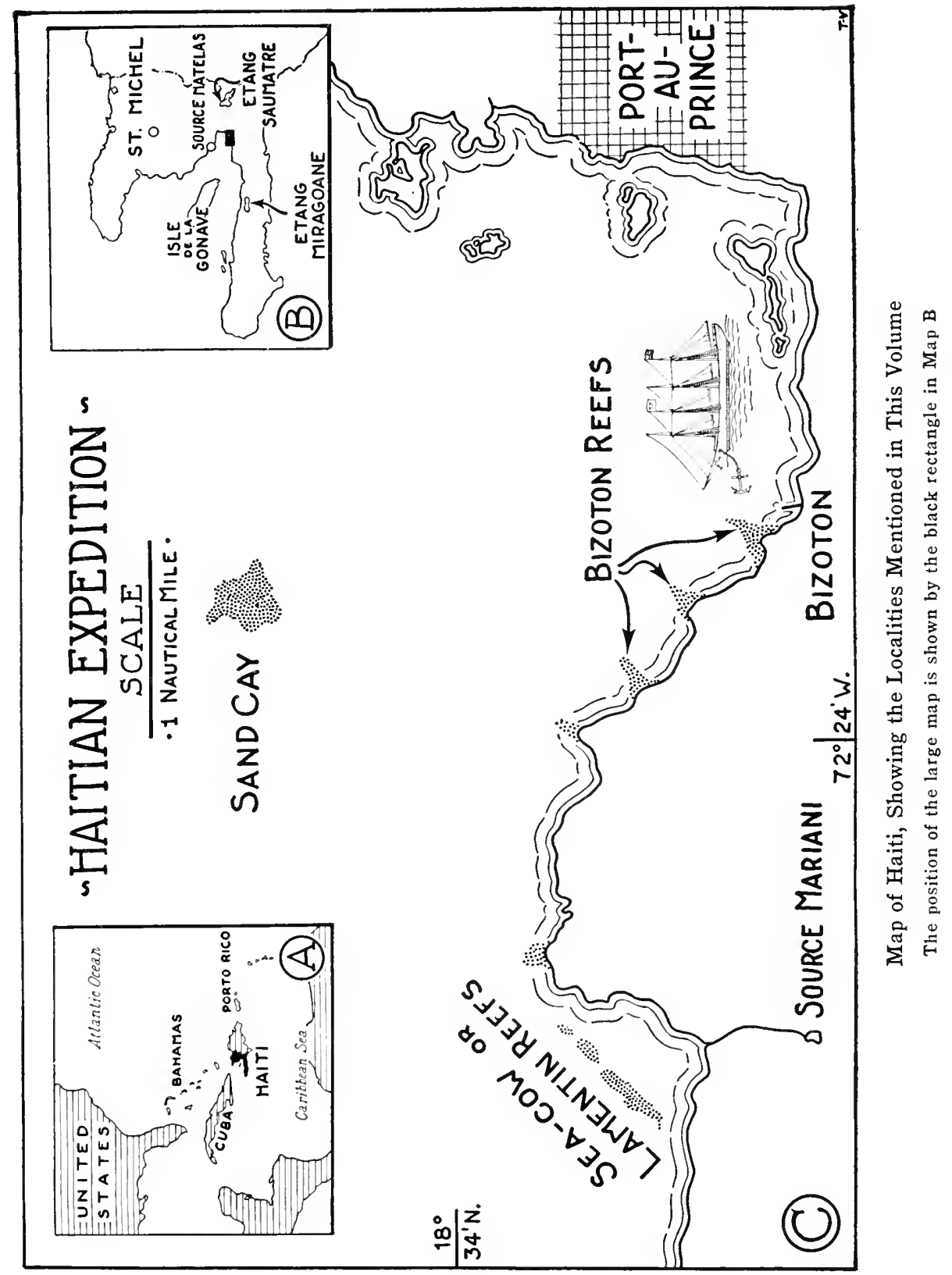





\section{HAITIAN CONTRASTS AND BEGINNINGS}

market she will sell her bundles of grass fodder for three gourdes, and with this sixty cents will return as leisurely as she came-the typical Haitian centaur on her way to her mountain home. But let this arouse no word of pity, for she has not come this incredible distance for the sixty cents. If you met her at the end of the first day and offered her three gourdes and a half she would probably refuse. Not for money would she forego the gossip and banter,-the joys of the nocturnal caravanserai, and the ultimate delights of strident barter in the great market-place itself,-with the joyful smells, and cries, and scenes which are so familiar to us all around the girdle of the globe. As she passes I greet her, "Bon jour, madame." And in the unexpectedness and courtesy of her reply she momentarily bridges all the differences between us. "Bon jour, monsieur; prend courage, mon cousin." And I return to my task with renewed courage born of the joy of contrast.

One afternoon I watched a game of polo, excellently played, between the Marines and officers of the Gendarmerie, and later talked philosophy at a sophisticated Colony Club. And that night the police handed in the following report of a voodoo dance three or four blocks away.

\section{"VOODOO DANCE AND SORTILEGE}

"Ten men, six women, and one gendarme, $\mathrm{E}-\mathrm{D} \longrightarrow$, 20th Co., were arrested at 11:00 P.M. 
6th., in connection with dance on Rue de Centre between the Tribunal of the First Instance and the Rue des Casernes. The dance took place in a court. Lt. C.— in making the arrest entered the court-forced as many as possible into a house and barred the house. The 17 arrested were in the house, but possibly 50 escaped. One man left his cutaway coat and black hat. A number of articles were seized—red coats with magic writing; a handkerchief with magic writing; banners; decorations; a music stand upon which was mounted a candle; stones; a number of bottles of ill-smelling oil; a box of sand which has an awful stench; a cane with a man's head cut upon it. This cane was wrapped in black cloth, and a pair of sun spectacles were tied to the head. Affair will be sent to tribunal today. Gendarme sent to his commanding officer."

As I finished reading this I remembered that at the Club a friend had refused to light a third cigarette with the same match, and many Americans had rapped on wood as they asserted that they had never had malaria. When I compared this with a handkerchief with magic writing I wondered if all my contrasts were as trenchant as they seemed at first sight.

The gods of expeditions have again been kind to me, and I can imagine no better place for a few months' work than Haiti. Owing probably to the brigands and danger from the natives up to very 


\section{HAITIAN CONTRASTS AND BEGINNINGS}

recently, there has been very little thorough investigation of the fauna of this island. Dr. Eckmann, who is here at present, has made a remarkable collection of plants. He has just returned from a 9,000 foot mountain with one hundred and fifty specimens, of which thirty-five are new to science. Dr. Noble has had good luck with reptiles, and Watson has collected butterflies. But since Cory, forty-two years ago, wrote of the birds, there have been no observations of their life histories and I am sure that thorough search would reveal more than one new species. ${ }^{\text {' }}$ There is not a single list of Haitian fresh-water or marine fish, so, although only five days from New York, in this respect the island is a virgin field.

Then there are the new ruins which have just been located by airplane; the strange Aztec-like clay heads of Cabrite, and the fossil-filled caves of Saint Michel, in which the barest beginnings of excavations have been made. My part thus far has been to check up all these interesting fields, to locate the best reefs, and the most convenient means of transportation and living.

Two hours of peering through a water bucket, only a mile from Port-au-Prince, revealed an undersea world peopled by the tiniest of fish and by giant sharks. I saw heads of coral as large as automobiles, and sea-fans waving gracefully sometimes many feet in height. Soon scores of scientists and

I Curiously enough, since this was written, Dr. Wetmore has confirmed my prophecy with $H$ aplocichla swalesi, a splendid new mountain thrush. 


\section{BENEATH TROPIC SEAS}

of laymen will be enjoying the delights of walking about the bottom of such reefs everywhere in the world, and the results in future years should bring joy to enforced city-dwellers, and hosts of new facts to the records of those of us who are ever trying to solve the ultimate mysteries of life and evolution on the earth.

After three weeks, at last I saw the topsails of my four-masted schooner, the Lieutenant, loom above the horizon of the Haitian sea. I thought of a queen ant spiralling slowly to earth, and in the light of succeeding events I could not consciously have chosen a better simile. On and on she came, the huge fore and mizzen sails wing and wing, straight in on the afternoon sea breeze, escorted by the tiny sheets of a flock of Haitian fishers.

I met her several miles out, with the Captain of the Port, and when we had boarded her he turned her sharply to starboard and by voice alone guided her in and out between ugly emerald water reefs, as deftly as a skater encircles airholes in spring ice. A few days before, $I$ had been wading in two feet of water in a reef just ahead. It seemed now as if nothing could prevent our nine hundred tons of wood and metal from barging into the coral, but at a low, gruff order and a twist of the wheel the enormous ship came up into the wind, slowed down, her hundreds of yards of canvas hung limp,out crashed the anchor chain and we all breathed again. It was a sight for ultra-modern engineers- 


\section{HAITIAN CONTRASTS AND BEGINNINGS}

this great craft with only the motive power of Columbus, manipulated amid narrow, crooked channels more skillfully than many a yacht impelled with electricity or steam.

The delicately graded stress of pulleys became a real thing to me this day as I watched a man lower a sail alone-a sail and gaff which would have crushed him flat had their weight not been distributed. Again the queen ant came to mind, for when she alights she too furls her wings, but it was not until a day or two later that the climax of the simile occurred, for then I watched the sailors untying rope after rope, rolling up the huge sails and dropping them into the dark hold; exactly as I have seen the queen, after her marriage flight, twist and bend and bite off her wings before beginning the shallow pit which in time will seethe with a million tenants.

At last the schooner stood bare, with her four masts rising up and up from the deck forever, like the slim, endless spires of French bayonets. She was stripped for action with a vengeance, and the action began at once. Out of the hold came Ford trucks, glass-bottomed and motor-boats, and tents, as well as five bags of tent-pegs. It then occurred to us that one does not drive pegs into the deck of a vessel, especially with the captain looking on. Up went the tents, and probably no stranger sight was ever seen on a schooner than the hatches and decks covered with a colony of these structures. We threw aside the tent-pegs, for lack of yielding 


\section{BENEATH TROPIC SEAS}

soil, and in their place developed a maze of crisscrossing ropes. A few days later when I flew over and, banking sharply, looked down, my vessel appeared like a giant spider-web adrift in the Bay.

It was a crazy, untried, landlubberish scheme which had given my friends much cause for mirth, but it actually worked, and now that we are in full swing we are as comfortable and as effectively equipped as we could wish. A large mess-tent is at one end, the laboratory at the other, and between are sleeping tents where one may lie under one or two blankets at night and never be too warm.

On the forecastle a diminutive engine mumbles to itself, and from it a wire winds in and out along the roofs of the tents like a slender jungle liana, only our wire-vine blossoms here and there into electric lights and revolving fans, or jiggles a little pump which sprays water into the aquariums. And finally it disappears into a great, white enamel affair and works mysteries in this tropical sunshine. Scores of tiny cups of water, under its power, become colder and colder and before long congeal into that strange thing ice, which without man's magic would never come to Haiti.

My tent door frames the high mountains which surround us, with their fringe of cocoanut and royal palms and the emerald water between. At six o'clock in the morning the valleys and crests turn to solid gold, and at six in the evening the shadows of the deepest gorges creep out and possess the 


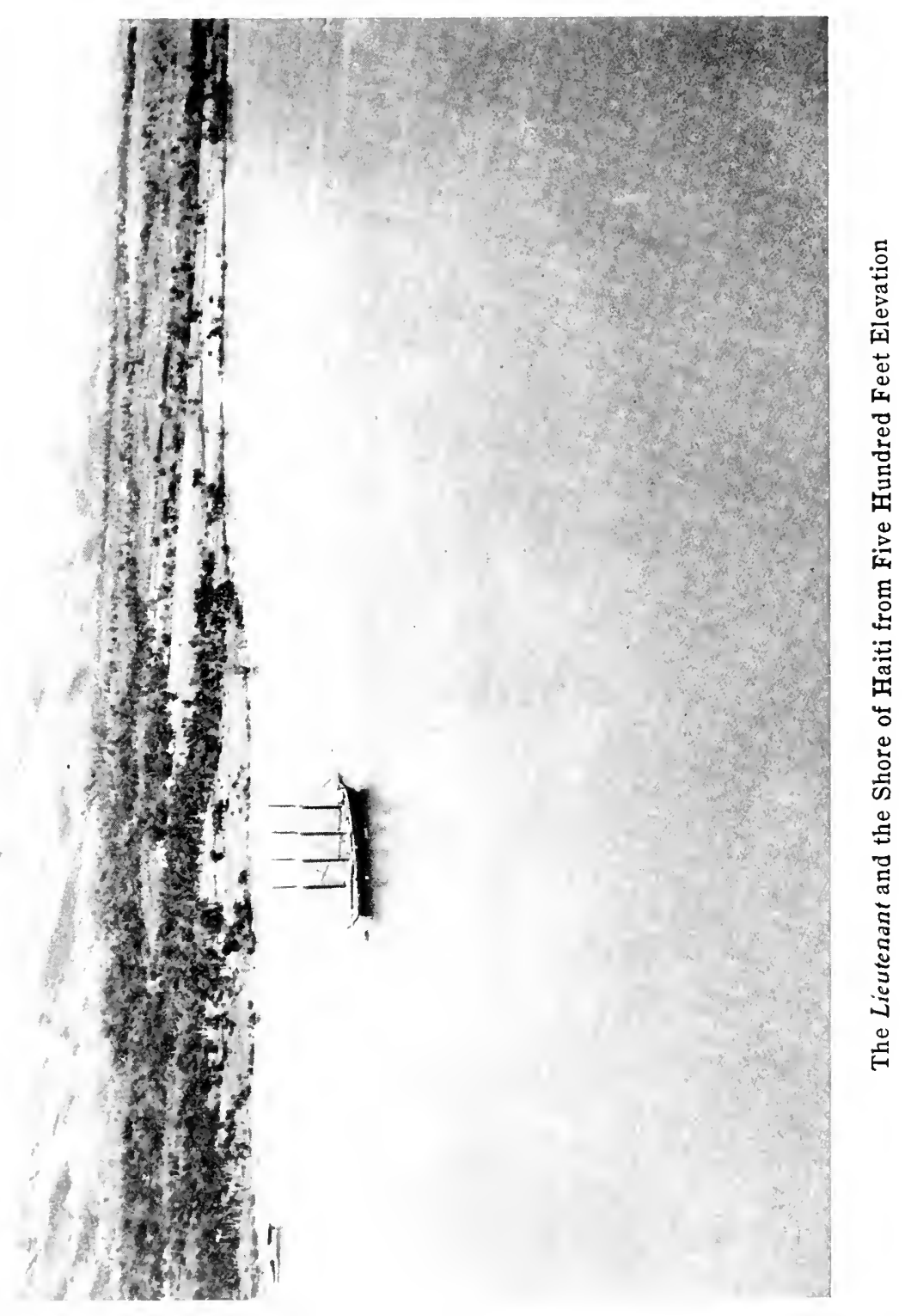




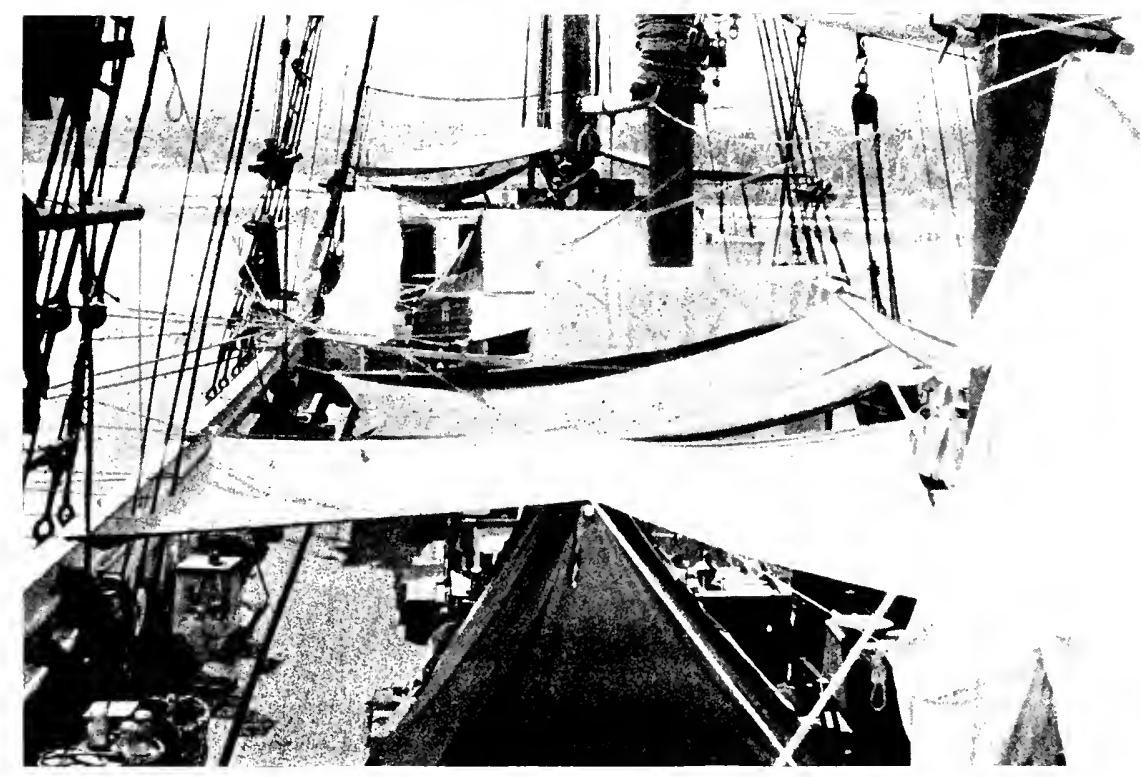

Tents on the Deck of the Lieutenant

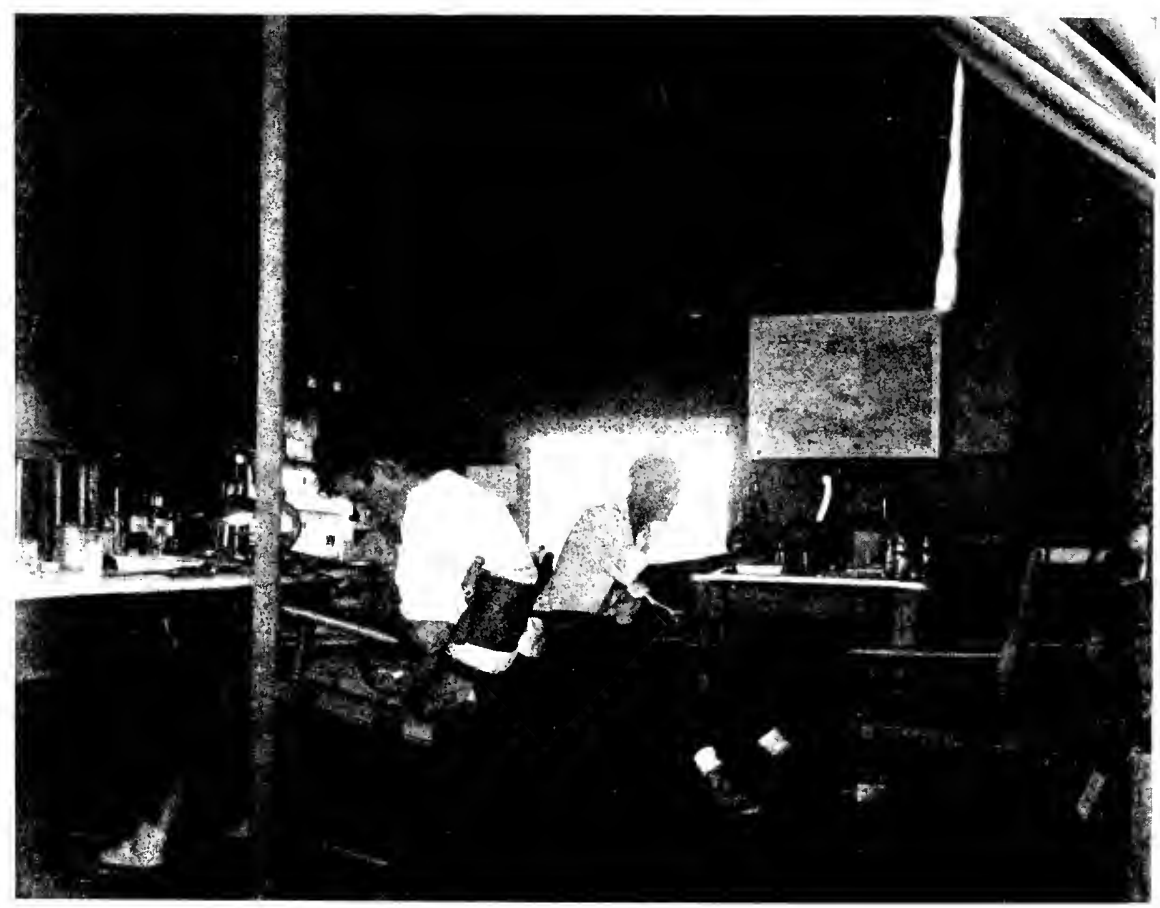

Laboratory Tent on the Schooner 


\section{HAITIAN CONTRASTS AND BEGINNINGS}

whole island. From this moment the sky is ablaze with starlight such as only the tropics know -Polaris low in the north and the Southern Cross lying quite on its side and just clearing the top of the mountains, half a mile above the bay. The minor constellation of Port-au-Prince emerges at dusk-a long row of scattered, twinkling lights along the distant shore.

Such is our new home in the tropics, isolated from all the troubles of life on shore, with never a mosquito from the marshes half a mile away, with no possibility of rain except an occasional shower at night, no storms to worry about, and a gentle current which carries past the gangway a most astonishing world of life. Long before I did any serious diving, I spent hours and days in careful reconnaissance. From five hundred feet in the air I spotted an atoll-like reef in the center of the bay with a ring of mighty coral and sea-fans deepening gradually into invisibility, and at one side I caught sight of six sharks milling slowly about something.

This place is Sand Cay, three miles straight out from the schooner and this I proposed to explore. One day I chugged out and through a water bucket verified the luxuriance of submarine growths. I observed only one incident but this was unforgettable. Three tall, round, hollow sponges stood close together like weird parodies of factory chimneys, but instead of ugly bricks they were fashioned of soft, velvety olive with orange mouths. As I looked, a flock of small, slim fish darted past 


\section{BENEATH TROPIC SEAS}

and with a single turn dived into the top of one of the sponges. Why they did this I could not then tell. After a month of watching I learned,-as I already knew why swifts similarly dive into our earthly chimneys.

Every sporadic trip showed what wonders awaited us. The shallow little reef a few yards away from the schooner looked rather barren under the clear sunshine. Almost all life sheltered from the heat and sun beneath the small corals and sponges which have rooted too near shore to develop fully. But a single trip by moonlight showed great crayfish half a yard in length, creeping about, and here and there sinister moray eels twined and twisted through the seaweeds in their search for unwary fish.

The marine corps telephone on the naval wharf rang sharply one day - an automatic phone such as is usual in wild Haiti-and Flight Lieutenant Boyden wished to speak to Dr. Beebe. The immediate matter was the annual bombing, the ultimate was rare fish. It was another of the unexpected and surprising modes of help which come to a visiting scientist in this island. The time was seven-thirty the following morning, the place Lamentin Bay - the Bay of Manatees-and the number was twelve bombs dropped by six airplanes. Each would contain one hundred and sixty-five pounds of H.E. and the results might be interesting to an ichthyologist as well as to the observing Major of Aviation. 


\section{HAITIAN CONTRASTS AND BEGINNINGS}

Next day broke clear as every day of February does in Haiti and the last lights were hardly out in Port-au-Prince across the bay as we began breakfast in the mess-tent. We took the schooner's big jolly-boat and towed one of our own, loaded with a multitude of hand-nets and pails. Westward, across reefs and around headlands we went, drawing a disturbed wake through emerald and ultramarine in succession as we passed over shallows and deeps. The surface was smooth and rolling and in every direction there hung and vibrated great moons of jellies, while between them smaller jelly planetoids swam into our ken.

Beyond the lighthouse we saw a half dozen native boats over the reef, the owners pulling up traps or spearing trunk-fish and sea-urchins,the latter for bait. Half a mile away was the bright orange target triangle, and past us roared the observer, sending down a friendly goodmorning wave.

Something drew my eye upward to where a silver mote hung in mid-air. It seemed motionless, but as I watched, it edged slightly seaward to windward of the target, - the first plane had arrived on time. It was all as planned and I enjoyed it to the full. In an hour I would be collecting fishbut I had not calculated on one small thing-a sound. Without warning there came simultaneously a whine and a splash. The sound of the bomb a mile overhead came to my ears exactly as my eyes saw it strike the water, and from watchful 


\section{BENEATH TROPIC SEAS}

waiting I became very much afraid. My sanity told me this was only a practice bombing, but my memory rushed me headlong to Trafalgar Square, to the Place de la Concorde and to Verdun. I wanted very much to get under a seat in the boat or pull something over me, but I did not, and a fraction of a minute later the whole sea near the target rose in majestic volume, a super-fountain of silver spray which sank or floated off in mist. For a long time there was a mound on the horizon at that point.

The silver mote wheeled in a two-mile circle, and this time I listened uneasily but attentively to the sound. In past years I had never done this. Dunsany has written of the hyena-like snarl of certain shells. This began as a sound of twanged wire-wire stretched taut to the breaking point. Then there joined to this an angry, waspish hum, a sinister rise to the beginning of the hyena's shriek which, as suddenly, passed into inaudible waves and the end was absolute silence-a terrible waiting for the dull boom of the depth explosion with its deep resonance. It was not nice to hear the Haitians in their fishing boats jeer and mimic the sound. Its terrible significance for me admitted, rather unreasonably, no excuse even for their complete ignorance.

When the last plane had dropped its load, it grape-vined downward in steep side banks, waved "all clear" to us, and rushed across the bay. We started our engines full speed and soon caught 


\section{HAITIAN CONTRASTS AND BEGINNINGS}

sight of the white bellies of floating fish. Some were dead, many were only stunned and we reaped a harvest. Almost all were large and of widely differing species; great rosy red snappers-the best of pan-fish, many-colored angelfish, groupers, trigger-fish with their poisonous triggers set at full cock as futile protection against this unthinkable danger, trunkfish whose shelter within their armored box was of no avail.

There were porcupine fish who at the shock had valiantly inflated themselves behind their chevauxde-frise of spines and so died, and there were mackerel-masters of the bay-whose sharp teeth and wonderful speed aided them not at all against this holocaust of vibration. And finally, here and there, like variegated water-lilies, floated butterfly-fish in gay pigments and patterns, with the colored eye-spots at the far end of their bodies appearing more alert and perceptive than their real vacant orbs. I thought of the hundreds of fish which must have sunk to the bottom, and the unending lines of influence which spread and spread - the news somehow going abroad of the wonderful manna at hand. For days and weeks to come, strange, beautiful, ugly and weird beings would continue to swim or crawl or creep toward the dead things which had given up their lives to make a bombman's holiday. 


\section{CHAPTER III}

\section{THE CEILING OF THE BAY}

Sand Cay was three miles out from the schooner, and every time I dived there, I spent a full hour in the jolly-boat going and coming. The bow of any boat is always north to the needle of my mind, and from the very first trip I sat Buddha-fashion on the coiled painter, observing and capturing what I could. It was interesting, day by day, to see how one's eyesight and skill with the net improved. In two weeks I had gained a hundred per cent efficiency.

No two trips were ever alike. There were days of this and days of that, and Easter Sunday was a day of creatures in millions. For two full miles of our course the sea was filled with vibrating thimbles - jellyfish of exactly the size and shape of these homely articles, close to the surface, fairly bumping against the ceiling of the bay. Sometimes they were swimming a foot apart, and again for hundreds of yards they were pressed against one another. They were tawny-olive and they swam in a curious way, an alternate opening and closing of the umbrella, oppositely and at right angles, not circularly as in the big aurelia moons. In a 


\section{THE CEILING OF THE BAY}

square foot of surface I counted seventy-four, and lying with my face close to the water I could see them, as abundant as ever, far, far down. I dipped up a hundred in a single scoop of the net, and when I watched them in an aquarium I saw, under a hand lens, differences, tears in the jelly, slight disproportions of size and parts, which made of each an individual, - a jelly separate and apart, with its own endurance and weariness, its preferences, achievements and failures. All this too, without in any way embarrassing it with anthropomorphic characteristics or abilities.

Although classified as plankton, and, as such, at the mercy of wind and wave, yet in a small aquarium, they were very definite as regards food and adaptation to the strange environment of confinement. Not only did they paralyze and engulf some of the small fishes which I had been at pains to capture and unwisely placed in the same compartment, but they somehow chose only the more succulent portions, rejecting the heads and tails.

A century ago Johann Friedrich Eschscholtz gave them the name of finger-nail jellies-Linuche unguiculata, but thimble jellies will serve our present purpose.

Their submarine history before they came to my notice is far from ordinary. In fact, man's untrammelled imagination has been able to equal but not exceed its bare facts. The barnacle goose is so-called because mankind, in its pleasantly 


\section{BENEATH TROPIC SEAS}

credulous way, has believed for generations that the long-stemmed barnacles of the sea occasionally open their ivory, valve-like gates to permit one of these geese, full-fledged, to make its escape. Today we, of a scientific turn of mind, sneer at the evidence of such superstitious ignorance. Yet our same scientific acumen has discovered and vouches for the life story of the thimble jelly.

Here and there on the corals and sea-weed, fathoms under our keel, are pale growths less than a half-inch in height. In places they are so dense that they appear like a furry covering. The imaginative eye sees them as alga or an aquatic mildew of sorts. These are animal growths although they have no sex-in which they are lower than ferns-and they increase by a simple system of stolon-like roots, in which they may call the moss, brother. Swellings appear at intervals upon their stems and elongate into a strange sea-fruit. As each bud grows it becomes repeatedly constricted until, in the course of time, it resolves into a pile of saucers. One day the uppermost, which by now has curved into a cup, wriggles in a manner unknown to its vegetative golem-like parent, breaks away, turns upside down, and, using up the last of our threadbare similes-throbs gaily off as a thimble jelly. With free movement has come sex, and the jellylet is followed by brothers and sisters from its own and hosts of other saucer piles, until in their thousands they swim into my ken, and in scores into my aquarium. 


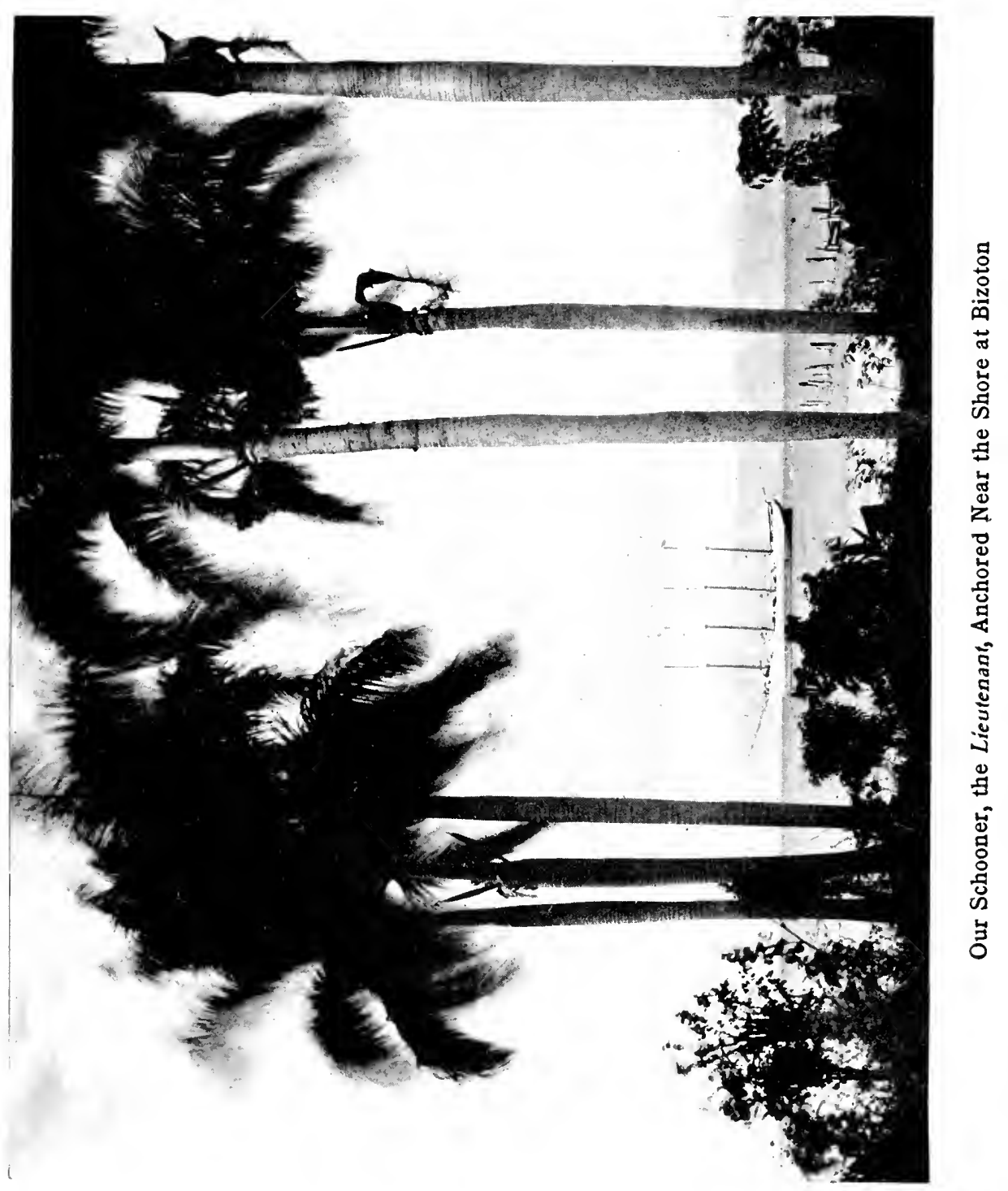




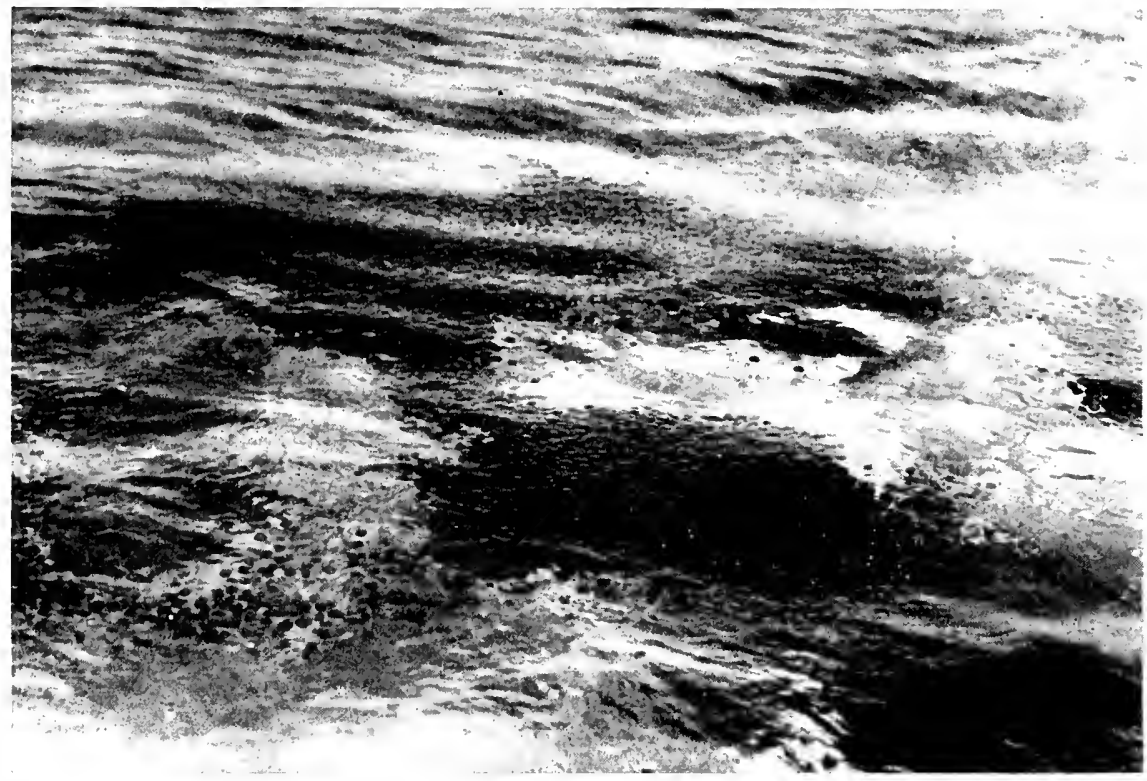

A Swarm of Thimble Jellies, Linuche unguiculata
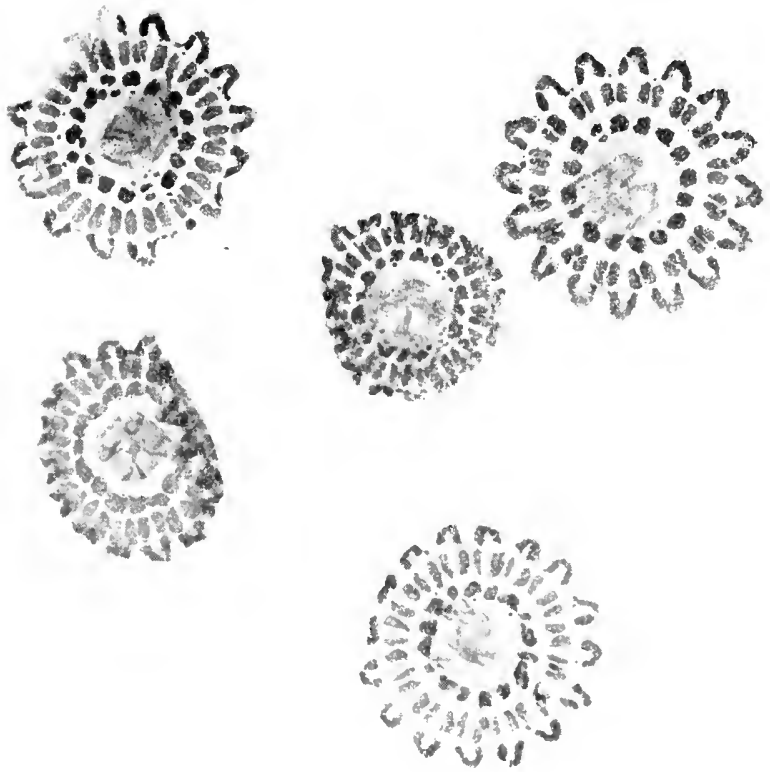

Five Small, Surface Jellies, Enlarged 7 Times 


\section{THE CEILING OF THE BAY}

After a few weeks the thimbles become mature, rise to the surface and discharge their eggs. This is said to be always at eight o'clock in the morning. When this is accomplished the innumerable host sinks dying into the depths; the great wheel of life has revolved a fraction of its arc; a million living beings have been snuffed out, and billions of new ones launched.

The day following the first appearance of the thimble jellies, they seemed more abundant than ever. They began a mile from the schooner and formed broad, brown ribbons in all the tidal lanes. While I was diving, the sea-breeze began, and tens of thousands were blown past. A pailful of water contained three solid quarts of them. When I hesitated on the ladder, helmet half under, the brown thimbles piled up in windrows against the glass in front of my face. Looking up from the bottom I could see every detail of their vibrating bodies.

They were so close together that they were pressed into regular honeycomb patterns hundreds in diameter. In several I could make out the bodies of tiny fish. They seemed to gather about any floating object, and when I began to retrace my path from the extreme length of the hose, I found its course marked by a solid band, two feet wide, of jellies, undulating and twisting with every wave.

Two days later, I saw only a single thimble jelly in the three miles of water. All the rest had vanished forever. 


\section{BENEATH TROPIC SEAS}

On several days great masses of sargassum weed drifted into the bay, and we had more than once to back out of solid fields and clear the propeller,- - an experience I have never had in the open Sargasso Sea. This weed was filled with the usual tenants, the absolutely bizarre sargassum fish, the weedcolored pipefish, crabs and shrimps, tiny banded Abudefdufs and the little trigger-fish, no whit different from the Joey of our Noma and Arcturus trips. Here too I found miniature triple-tails (Lobotes) looking like nothing in the world. We caught sight, now and then, of very small, brown, wriggling worm-like fish, and after many attempts caught one, and found it was a diminutive gar,short of beak, toothless, but active and fierce in anticipation of its voracious life when its great rows of needle teeth backed by five or six feet of solid muscle would make it a most formidable adversary.

The sight of the little gar cringing beneath a sheltering strand of weed, recalled a recent activity of one of its uncles or forefathers. Early one morning near the schooner we saw a disturbance in the water, and found it was made by about a hundred little puffers, all massed closely together and swimming steadily ahead. A flash of white, astern, sent them on faster and impelled them all to swell slightly. Then we saw the long, dark form of a four-foot gar drawing nearer. The timid puffers saw him too, inflated still more, and bunched together, swimming so inconceivably close that the school appeared like one large, round 


\section{THE CEILING OF THE BAY}

fish. The gar leaped at them and disturbed the mass, causing every outside puffer to bore inwards with all its little might. Immediately the gar turned and sounded swiftly without having caught a victim. The puffers went on, so pressed together that it seemed as if the fins of the outside layer must furnish all the propelling power. Like the hollow square of a herd of musk oxen with horns all pointed outward, the puffers presented to their foe a solid, chevaux-de-frise of prickly spine,- - a mass far too large to be swallowed whole.

Suddenly a single puffer separated itself and streaked away at right angles. When it had gone twenty feet I saw the gar after it, and a moment later the great jaws opened, snapped shut, and drew the unfortunate puffer down. To the human palate this titbit might be compared very precisely to a full grown chestnut burr.

No magician ever produced more from an empty hat than a single sweep of the net would often reveal under the barest bit of sargassum weed. From one scanty frond came a trio of small squids. They had made themselves of exactly the weed shade, and even after being lifted from the water they still clung pathetically to the hue which up to this moment had protected them from every foe. Then suddenly, in mid-air, all realized that they were a color behind their environment, and, as one squid, all promptly switched to white, the color of the net. I dumped them unceremoniously into a quart mason jar, and like triplet Tweedledees, all 


\section{BENEATH TROPIC SEAS}

lost their temper at once, and played their last card-shooting out an impenetrable smoke screen of sepia. Heartlessly I emptied and replaced the water, and after the third time their little fountain pens ran dry, and after a few futile skeins of palest diluted grey, they gave up and waited for whatever fate the god of squids might be pleased to mete out. If they were terrified it did not affect their appetite and each seized a tiny fish with eagerness, one of them putting a second under his arm, or one of his eight arms. They shot about and played at spectrum, shifting from greyish white to opaque brownish black, in this latter phase glittering with solid iridescence in the sun. Between times, they dressed up in pink or yellow or carmine, or, with one accord, draped three broad bands about their bodies.

While the squids were doing their stuff, an unexpected performance was suddenly staged in the jar of sargassum fish. There had been three, sized like the three bears, and after half an hour we found that an inverted magician's trick had been performed - to my astonishment, where there were three, was now but one-a Pterophryne very fat, and gulping uneasily. The awful truth gradually dawned upon us, but we never settled whether it was a case of the Japanese boxes-each within the other, or whether the big camnibal had in turn engulfed his spiny and much tentacled brethren. The same thing happened later, on the schooner in an aquarium, in the interval of focusing a camera 

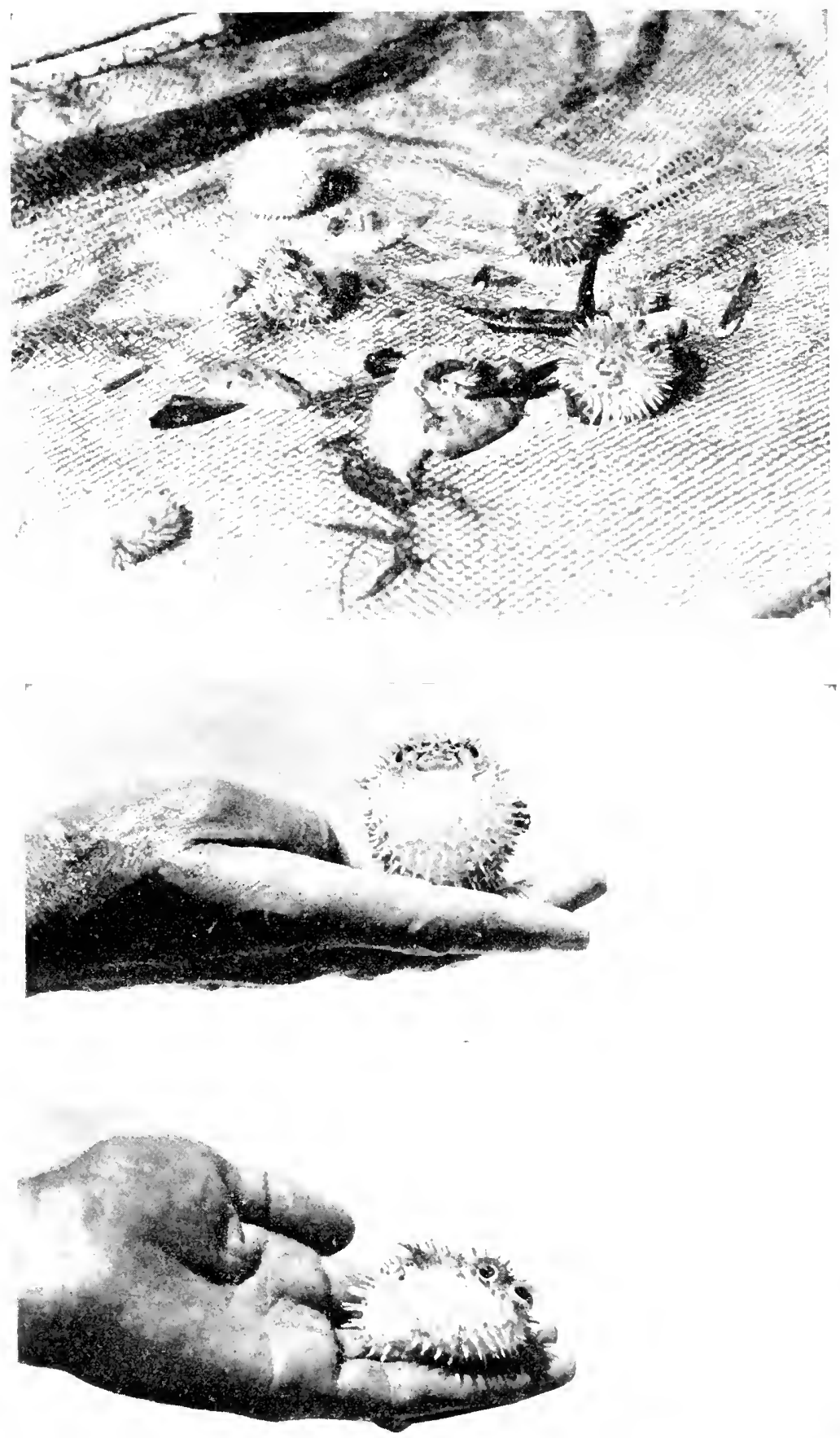

Puffers, Diodon hystrix, Inflated and Deflated 


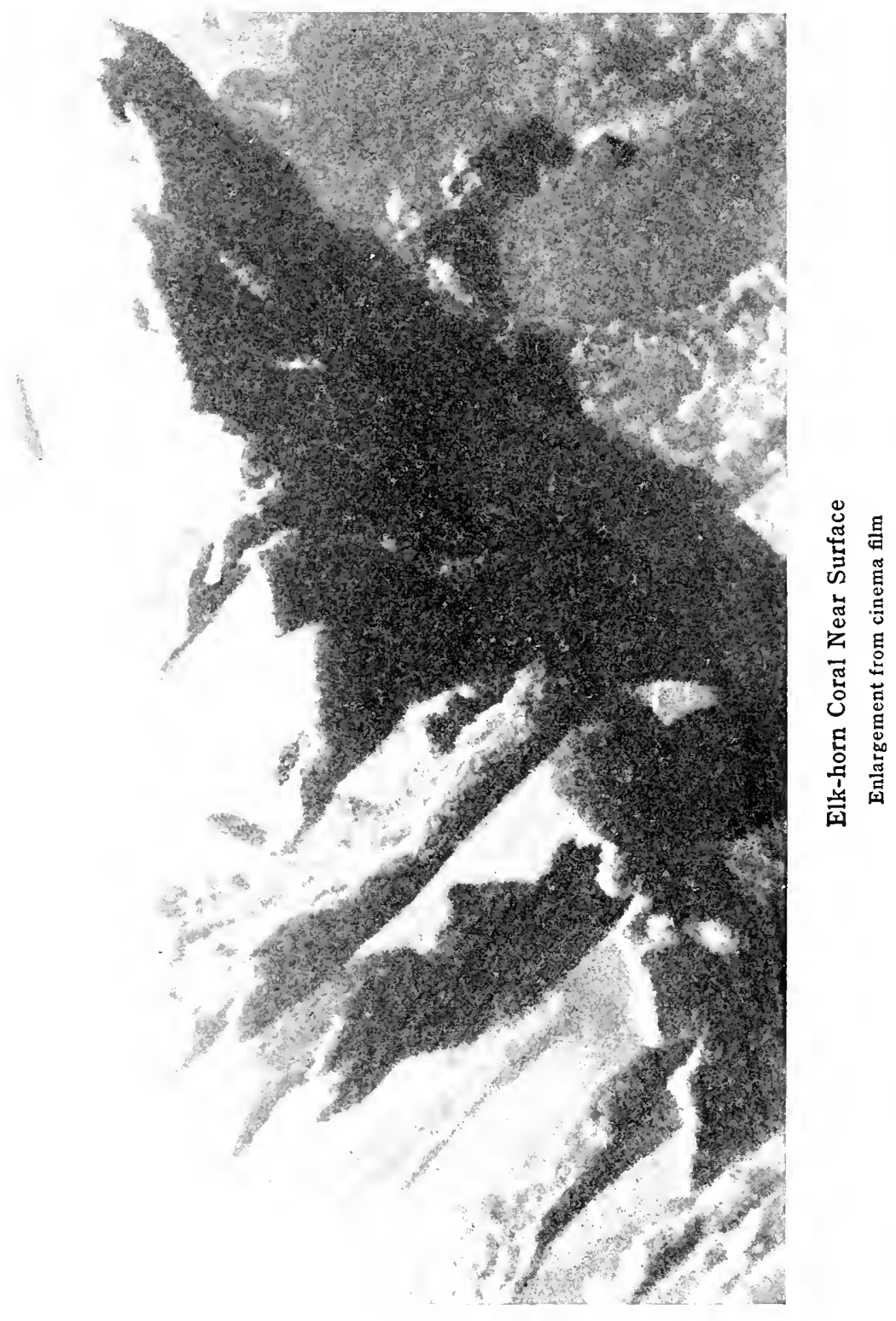




\section{THE CEILING OF THE BAY}

-now two, now one fish. Between cannibals and astonishingly voracious jellyfish I had trouble preserving any of my small captures.

On this same Easter Sunday as we neared the beacon marking Sand Cay, the narrow streak of turquoise of the reef gradually opened out into a great oval. We slowed down the engine the better to watch for the first faint slopes, deep, deep down, tangled with mighty corals and gorgonias, with sharks and huge groupers seeping slowly in and out of the shadowy gorges. The reef rapidly shoaled and in twelve or fifteen feet of water I anchored and prepared to dive. From directly ahead, a brown pelican flapped slowly along, wheeled suddenly and went into a nose dive. He struck the water with a crash, his great pouch swelling out to unbelievable proportions, then righted himself, and went through a series of swallowing motions, something like a person saying Ahhhh at the doctor's. On the instant of his strike, a wave arose from the calm surface-a living wave of thousands upon thousands of droplets of fishes, which sprang in an agony of fear from some great pursuing fish into the maws of our quintet of pelicans. For an hour or two this continued, sometimes five living waves being in sight at once, vibrating between the great yellow-tails and the birds.

When I submerged, the Easter theme, presaged by the jellyfish, held true, and trillions of the small fish drove past and back, swerved and milled until my eyes ached watching them. This watching 


\section{BENEATH TROPIC SEAS}

was the more difficult because it was intermittent, - there being several oblique angles at which the fish vanished from view altogether. This occurred most often when seen from a sharp angle below, whence, to the fish, invisibility would be of the greatest value. When once their silvery sides flashed out however, there was no need of any special observation on the part of the attacking fish,- they were in such tremendous numbers that any rush, however blind, in their direction must reach all that any hungry pursuer could swallow.

The technical part of my brain told me that these uncountable schools were Jenkinsia and Atherina,-herringlets and silversides. But after an hour or more of diving among them I began to cease thinking of them as individual fish. They became mere aquatic corpuscles, submarine atoms, whose structure was elemental, with movements governed by some mechanical interaction of cosmic influences. I secured one as I ascended the ladder, and examined it as I warmed up.

It was a silverside (Atherina), a female, and I later found that it contained one hundred and sixty-three eggs about to be laid, and four hundred of a later batch. Nothing atomic about this,it was an individual with a brain, eyes and muscles, and it had eighteen tiny crustaceans in its stomach; it had suffered adventure-a patch of scales and half a fin were missing; it had hopes of a mate, and expected to be able to deposit its eggs and leave 


\section{THE CEILING OF THE BAY}

offspring. And these considerations left me with a very confounded idea of the meaning of existence, as I saw its fellows in untold myriads leaping for their lives, with apparently only the choice of going to nourish either a fish or a bird.

During another 'tween dive and warming we shot a pelican and found sixty-five of the small herrings in its maw, all fresh and uninjured. Twice I saw a pursuing yellow-tail and a pelican collide, the one rising, the other diving, both keen to reach the heart of one of the living waves of fish.

Before I submerged in earnest, a new phase of live nursery presented itself. There floated slowly past an immense jellyfish, quadrangular, varnished with pale blue, with a wide purple fringe around the opening, while the body as a whole was deep, rich wine color. It was captured and inverted in a large water bucket which it overflowed. The outside was formed of great convex-surfaced, pillar-like scallops, covered sparsely with blunt thorns, and it weighed ten pounds. Later I identified it as belonging to the genus Chiropsalmus and probably to the species quadrumanus.

The amazing thing was that it was overflowing with small fish, all alive, all crowded into its interior. Many escaped while it was being salvaged, but I found that there still remained three hundred and three bumpers (Chloroscombrus chrysurus) measuring from one-half to two inches, 


\section{BENEATH TROPIC SEAS}

while there was a single small harvestfish (Peprilus paru). There must have been at least three hundred and fifty small fish in the heart of this mighty jelly when it was vibrating slowly along,a strange enough nursery for the most imaginative fairy tale, yet in full swing here in the light of day.

I began this chapter with the theme of creatures in myriads and now I shall return again to the vast schools of tiny fish at Sand Cay and my experience with them on one of my last dives.

We had set off two sticks of dynamite with the usual excellent results, and there remained in the locker half a stick. As this might be our last visit to the reef, the half portion was exploded and I dived at once.

I saw an astonishing sight. A few minutes before, as I came to the surface, tens of thousands of the fish motes had shot through the water about me in all directions, still striving with their utmost skill to evade both the voracious yellow-tails and the fatal gape of the pelicans. It seemed as if their whole life was a constant breaking through the water ceiling and the air floor.

Now, in the very spot I had left a few minutes before, the whole water was filled with silvery motes, gently scaling downward. The explosion had occurred in the midst of a rain of fleeing silversides and the water and the reef floor looked like the tinsel on a Christmas tree. I was stricken with regret for having ended so many lives at once, but my sorrow was ill-timed and quite premature. I 


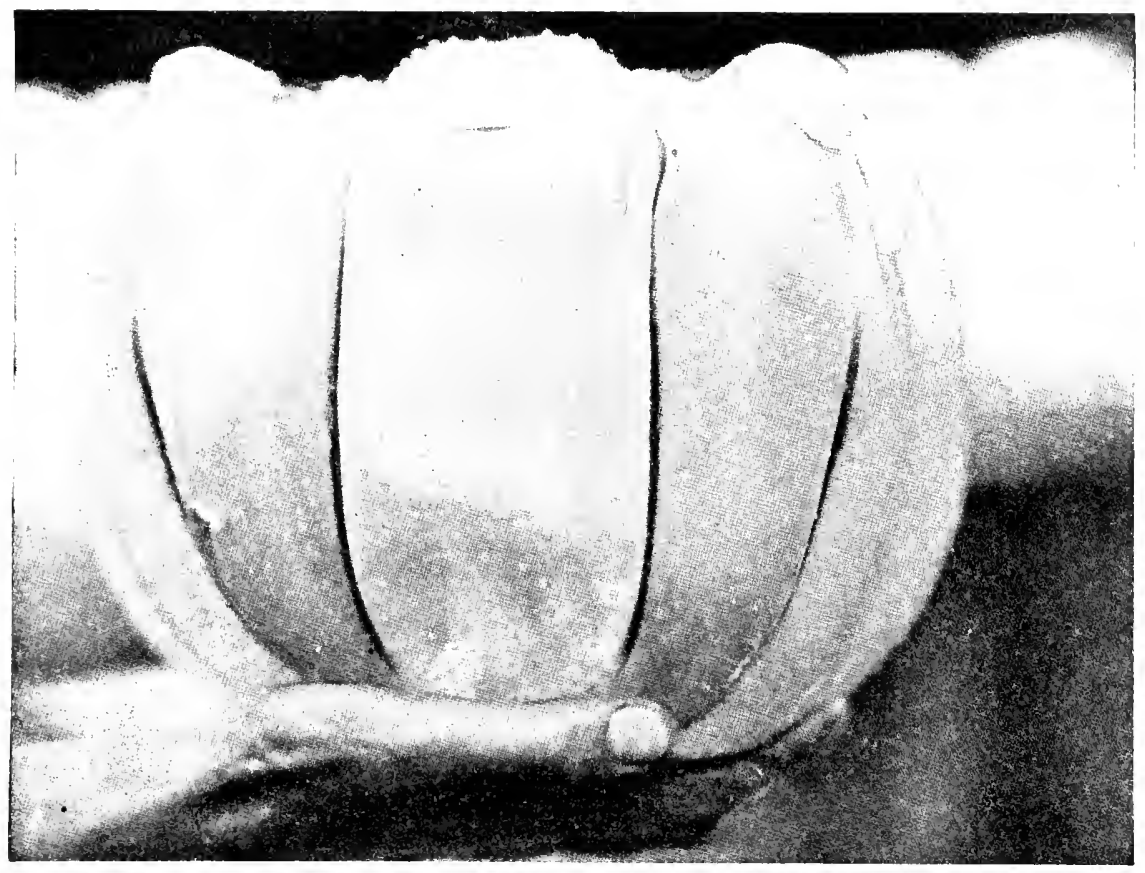

Giant Jelly-fish from the Side

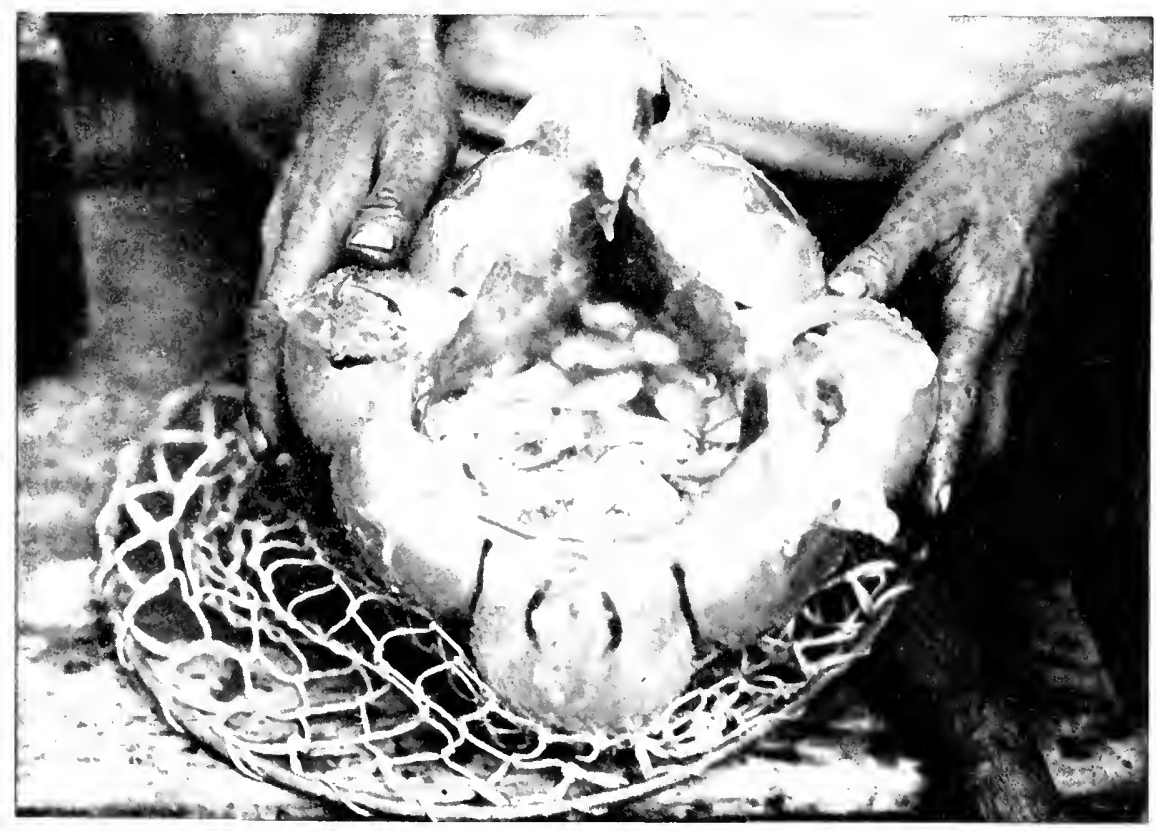

Giant Jelly-fish from Below, Showing Some of the Three Hundred and Fifty Fish Living Inside 


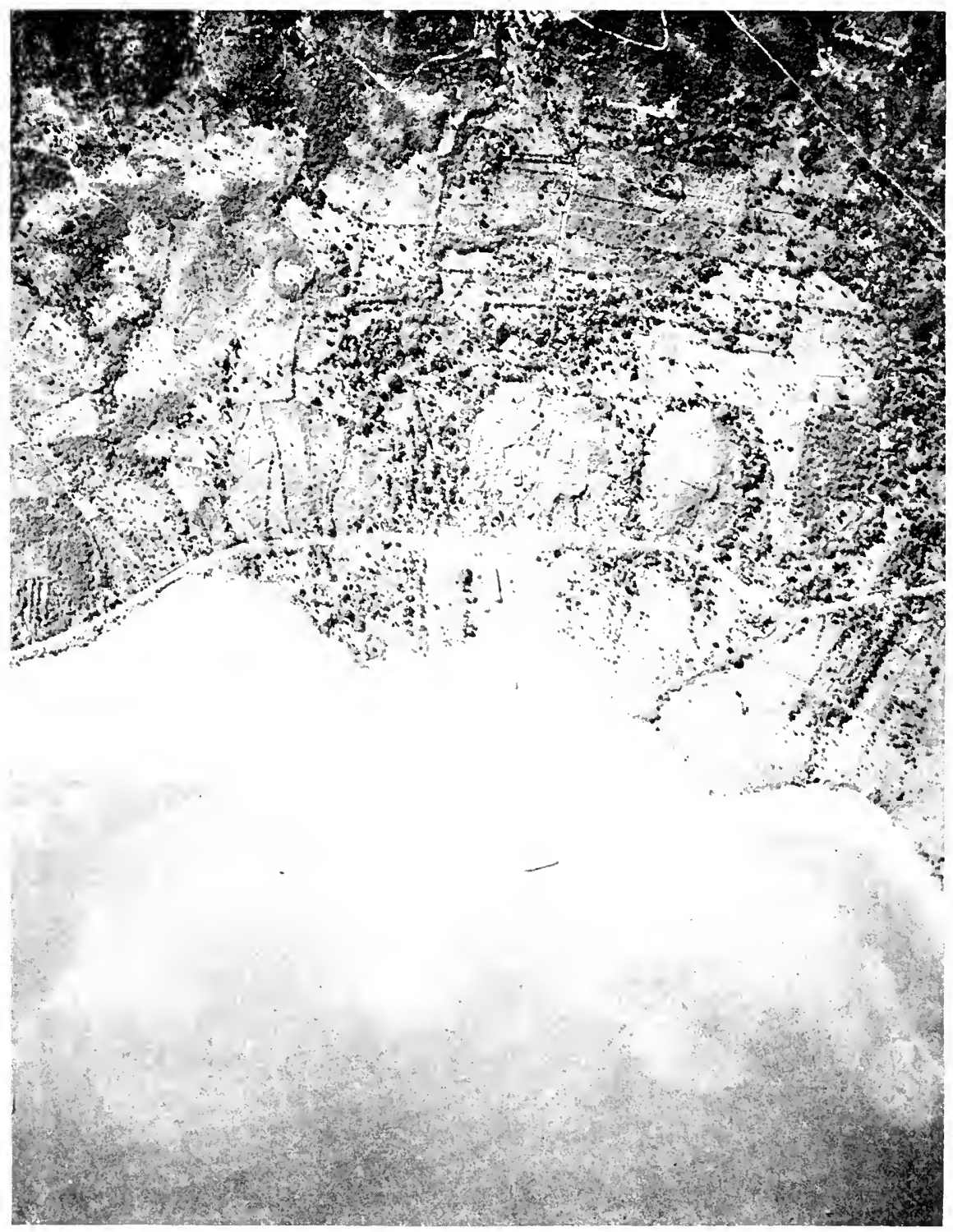

Airplane View, One Mile Up, of the Lieutenant, Haitian Shore at Bizoton and the Coral Reefs 


\section{THE CEILING OF THE BAY}

began searching for rare fish and found as usual that all kinds except wrasse had succumbed.

At last I climbed up, and, after an interval, again dived. Most of the tinsel fish had disappeared from the reef floor, not, as I first thought, all devoured by larger fish, but resurrected, gathered in dense masses in mid-water, swimming so closely together that each group was opaque. Three great mobs of fishlets were milling about, not only as regards the whole, but each individual slowly turning on its own axis, not very fast but rather regularly.

I approached and, to my surprise, found that they did not move away. I put my hand among them and touched many as it was moved to and fro. I caught several in my hand.

I climbed part way up the ladder and signalled for a net, and by moving it slowly back and forth, in three sweeps I captured one thousand and fiftythree of three species-silversides and herringlets. This made no impression whatever on the general numbers and I watched one very interesting event. This was the approach of two swarms-in their present condition they deserved no other name. The two came slowly together and partly coalesced, and then again separated. Each was made up of the same small species, but each was milling at different rates, and the two masses actually met and passed through one another without losing their individuality or general numbers or direction. It seemed as if the slight difference in reaction 


\section{BENEATH TROPIC SEAS}

to the explosion was a factor more potent than the recognition of one another, or the yielding to the usual spirit of the school,-a synchronized movement, speed and direction which seemed beyond the power of the individual to resist.

Before I reascended I again tried to approach the various masses, but the fish were recovering rapidly and although still revolving, yet they avoided me and I could not capture one. Eventually, all, except those actually injured or torn by the impact, recovered, to take up their more normal frantic fleeing from danger.

Toward the end of the dive I sat on white sand and watched the surface above me. The sea breeze had sprung up and it was fairly rough. The view from beneath was of green, wrinkled, translucent ceiling cloth, never still for a moment, crinkling and uncrinkling, waving and flapping as in a breeze, or rather cross breezes. It was decidedly green in comparison with the ever more blue distance,-turquoise green in the sunlight, changing toward greenish glaucous in shadow. As to the distance, I can never get away from the idea of the most diluted, ethereal ultramarine, and yet my mind knows that a dozen other colors are somehow in it.

As to the opacity of the ceiling, I thought it absolute until I threw my head back as far as I dared, and saw, almost directly overhead, facets of clarity, appearing and vanishing, showing me an instant's patch of sky, a momentary glimpse of 


\section{THE CEILING OF THE BAY}

friends or boat-of that world to which it seemed at this moment inconceivable that I belonged. But anywhere except straight above me, the ceiling of the bay was watered gauze. 


\section{CHAPTER IV}

NO-MAN'S-LAND FIVE FATHOMS DOWN

Human life is bounded by less than two hundred degrees of temperature, about five miles of altitude, and by the presence of a delicate mixture of gases called atmosphere. To win into a new phase of life outside these realms is to be born again in a new incarnation, and to relive the enthusiasm of far distant aquatic ancestors. Nearly four-fifths of the surface of the earth is covered with water, and although two-thirds of our body consists of the self-same fluid, yet we are so intolerant of this wonderful substance that we can breathe it only as gaseous clouds, paddle about on the surface of the liquid, and skate upon the solid. Five minutes immersion spells certain death.

I have been fortunate enough to go St. Peter one better, and to walk about on the bottom of the sea during this winter in Haiti. In the course of three hundred odd strolls, one of the most astounding things was the color of this new world. With constant use of the helmet and clear glass windows, there came after a while a forgetfulness of the new medium I had entered. High and low tide came to have no meaning; the shore, as a definite thing, became non-existent, and my mind completely 


\section{NO-MAN'S-LAND FIVE FATHOMS DOWN}

bridged the gap between the last view of the palms and mangroves, which blurred out as I submerged, and the first clear glimpse of the same littoral slope so forever wet that one never thought of it as even damp. A dew-drenched lawn is wetter by far than anything $I$ have ever sensed beneath the waves.

Color again!

When our first ancestors had temporary surcease from the worry of securing food and fighting off enemies, they began to take note of color. Some man was the first to bring flowers into his cave and stick them into a crevice. And when he found bright-colored stones he bored holes in them and tied them around his neck and fingers. Thus the first interior decorator was a cave-man. The flowers faded, so, like Lorelei, he came to prefer the stones until he learned to daub with pigments on the rocky walls of his home;

"Unusually clever he,
Unusually brave,

And he drew delightful Mammoths

On the borders of his cave."

Of all places in the world a coral reef is unquestionably the newest and the strangest from which to draw satiety in color.

When I first began going down beneath tropical waters in my diving helmet, I found myself re-living the cave-man's evolution. Whether the nearest 


\section{BENEATH TROPIC SEAS}

coral was warm buff or primuline yellow was quite subservient to the fact that it might shelter a lynx-eyed octopus, and until I learned to know better, the sight of an approaching shark sent messages to portions of my brain far other than the seat of appreciation of color and beauty. It was necessary to get used to the strange costume, the complete submergence under water and the excitement of a new world of unknown life.

In the course of time I have learned to tramp about coral reefs, twenty to thirty feet under water, so unconcernedly that I can pay attention to particular, definite things. But after all my silly fears have been allayed, even now, with eyes overflowing with surfeit of color, I am still almost inarticulate. We need a whole new vocabulary, new adjectives, adequately to describe the designs and colors of under sea.

The very medium of water prevents any garishness, its pastel perspective compels most exquisite harmony of tints. Filtered through its softness, the harshest, most gaudy parrotfish resolves into the delicacy of an old Chinese print, an age-mellowed tapestry. If one asks for modernist or futuristic designs, no opium dream can compare with a batfish or an angry octopus. The night overhead glories in a single moon; here, whole schools of silvery moonfish rise, pass and set before us, while at our feet rest constellations of star-fish-crimson, sepia and mauve.

An unreal, fairy fish of greens and blues and 


\section{NO-MAN'S-LAND FIVE FATHOMS DOWN}

purples appears in the distance, vanishes forever, yet the next moment is close to the glass of our helmet, peering in at us, mouthing soundless Ohs! We try to catch him, with the same success as snatching a sunbeam from the upper air. As he balances calmly, easily, in mid-water, we count the distinct colors on his scales, and stop at the fourteenth, for he has shifted slightly and every single tint and hue has altered.

I walk toward a coral palace in the distance and work more magic. It is of the most delicately tinted lavender, picked out with patches of orange. I lean closer to get the exact shade, when every particle of color vanishes-the feathery-headed worms whose tentacles covered the surface have withdrawn like lightning into their tubes, and I see that the orange was merely reflection and that the coral is actually salmon-pink. My hand now brushes the surface and between winks the thousands of minute polyps disappear within their stony home, revealing at last the beautiful clear ivory of the real coral. Bewildered after this three-ply palimpsest of color, I look aside just in time to see a fish, in brilliant shining blue with three broad, vertical bands of brown, swim slowly into a fairy cavern. A few minutes later the identical fish emerges clad in brilliant yellow, thickly covered with black polka-dots.

This spirit of astonishing happenings, of exquisite magic, of ineffable, colorful mystery is the theme of this watery world, and should be the chief 


\section{BENEATH TROPIC SEAS}

motif in any writing or painting inspired or influenced by it. For while the roses and peonies of our gardens may look differently in light and in shade, they certainly, when alarmed, do not dash into the ground, and when we see a tortoise-shell tabby disappear into an alley, we can be reasonably sure that it will emerge practically the same color.

One artist, Zarh Pritchard, has brought to canvas, evanescence of hue, tenuousness of tint eminently satisfying to the memory of the stroller among coral reefs. This is probably because he paints under water, seated among his subjects. No aquarium tank can ever show the pastel film of aquatic perspective. No glass-bottomed boat ever conveys the mystery and beauty of this underworld of color, for the same reason that an exhibit of pictures viewed from a gallery directly overhead can reveal nothing but frames and foreshortened canvases.

Time after time I have come out of the water with my mind crowded with color impressionsbut never primary, harsh reds or blues or greens. Now too, I realize the importance to an author of the ultimate connection between colors and their man-given names. Striving to fix and identify remembered hues of a coral grove, I lose faith in my memory when, in my color book, I find them listed as Russian blue or onion-skin pink. I know the exact shade of a certain feathery sea plume, but resent having to refer to it as zinc 


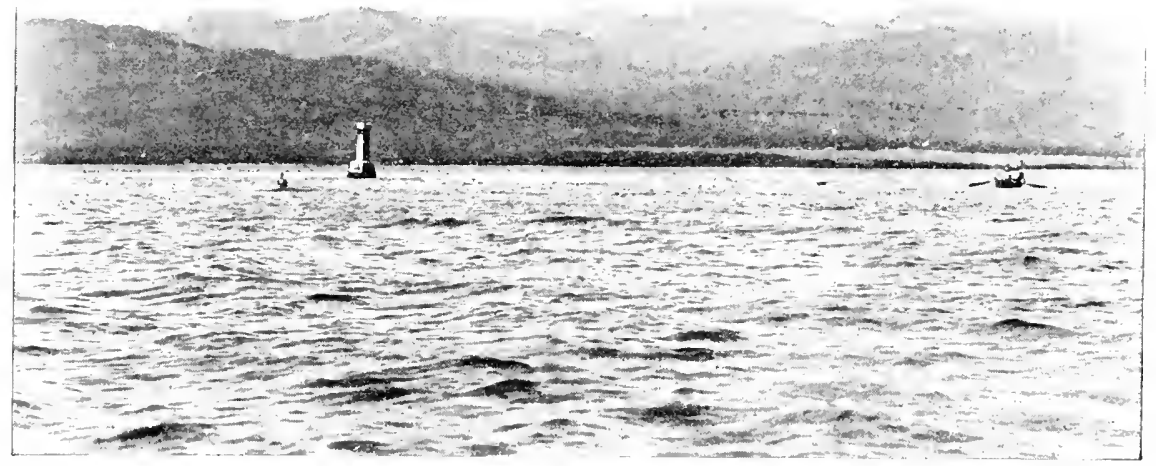

Sand Cay and Beacon from Motor Boat

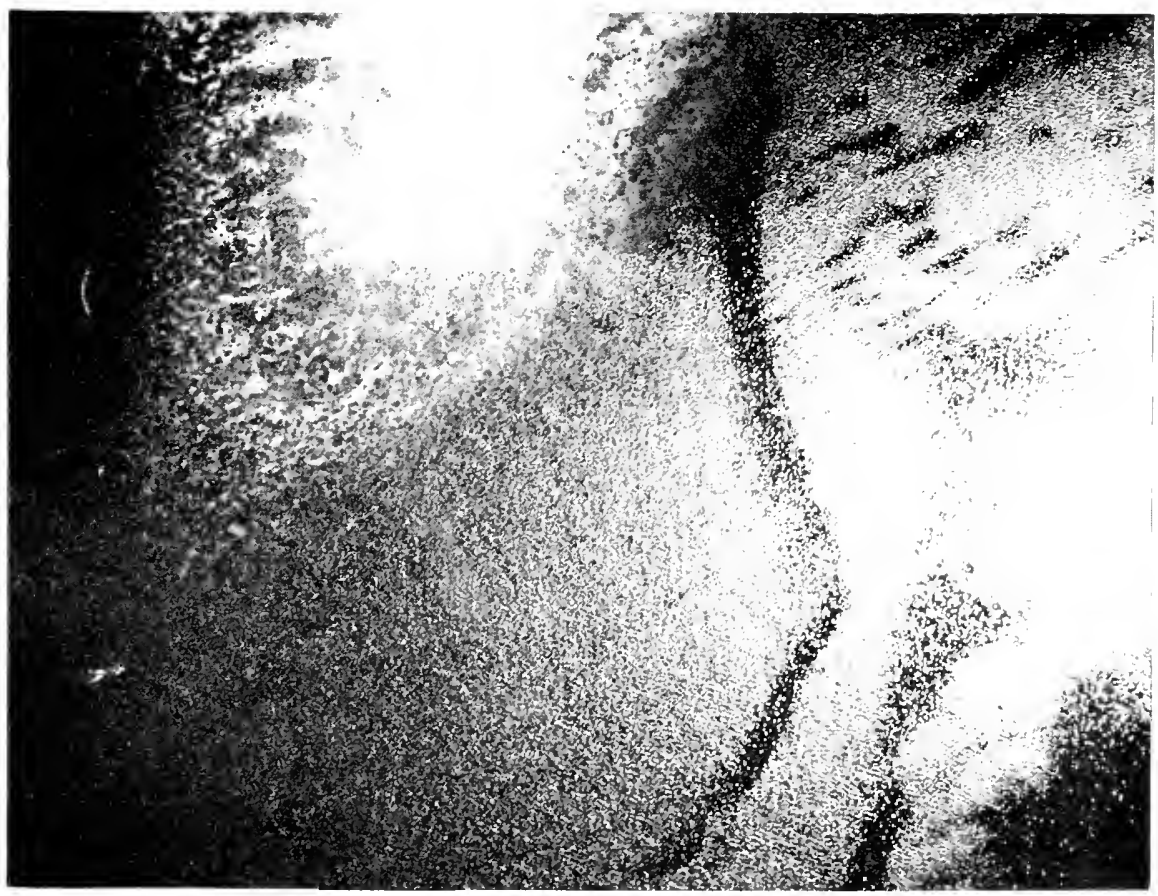

Sand Cay as Seen from Airplane, One Mile Up 


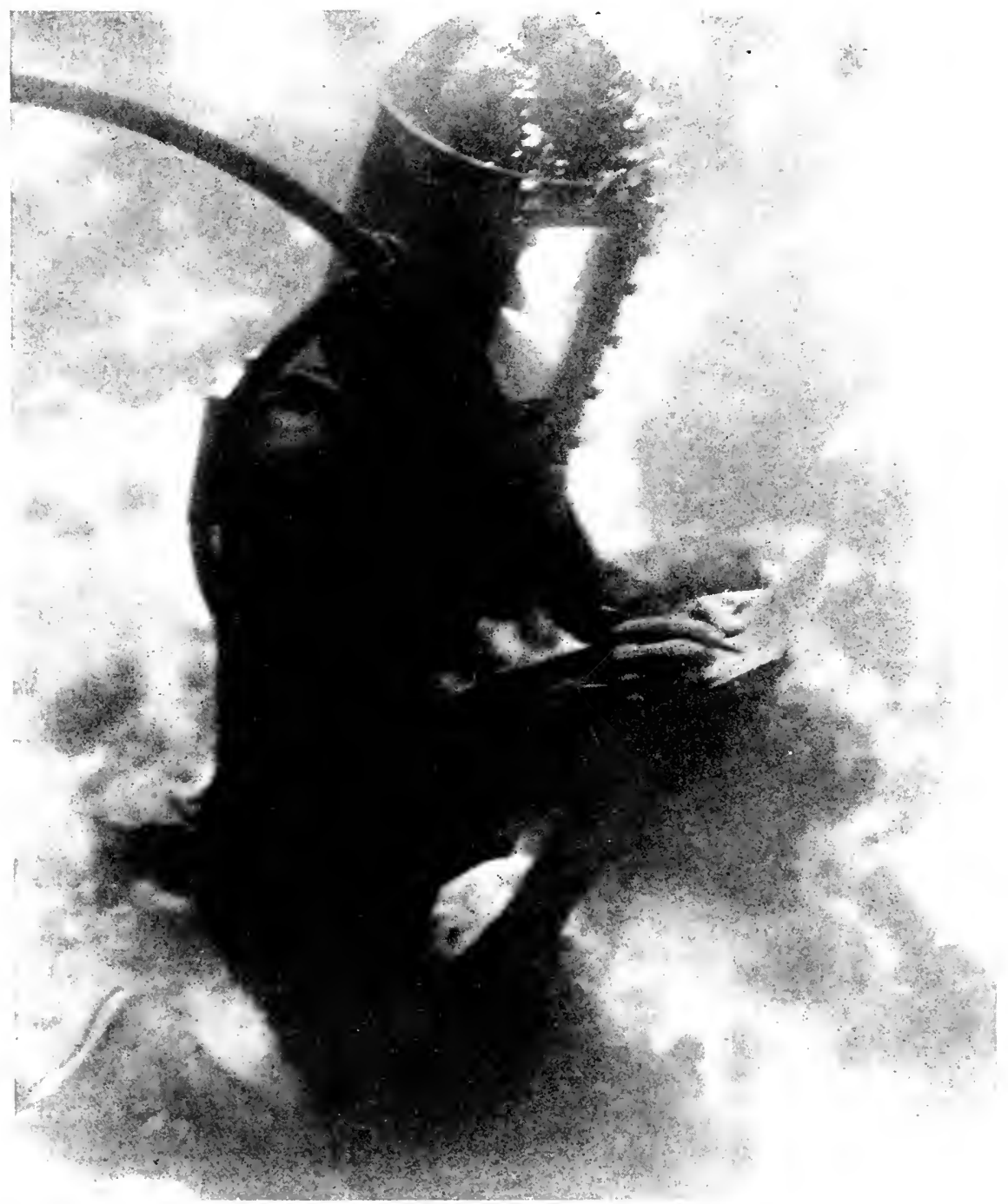

The Author on a Coral Reef, Writing on a Zinc Pad with Lead Pencil 
orange. Yet I am always pleased when I detect salmon, or pearl-grey or ultramarine. How I wish that the inventors of the names of colors had been imbued with the simplicity and the imagination of those who, through all the years, have acted as little Adams to the flowers.

Some day, when I can carry a color book in my helmet, I will be able to enumerate an exact color code of distance. Even in our colder, thinner atmosphere the green of mountain slopes softens to purple a long way off, but on the bottom of the sea, still greater changes take place within a few feet or yards. I have walked backward and seen a feathery-crowned sea-worm of dragon's blood alter, in my vision, within a few seconds and steps, to the palest of coral pink; while a sea-weed, deep olive-green when within reach, comes gently to the eye, when five yards away, as faintest glaucous.

An artist of great skill and patience can approximate the oxydized royal purple of a gorgonia, even the pink and ivory sunset of a conch shell,-but the vanishing point of distance beneath the water, where the coral reef ends and the mysteries of the unknown deeps begin - the illusion, too subtle for color, of submarine visual infinity - this is not to be whelmed by man-made brushes nor imprisoned on any terrestrial dimension.

It is the custom nowadays to "do" a city in a day, or a cathedral in an hour, or even to produce a volume of solemn critical comment after the 


\section{BENEATH TROPIC SEAS}

most frightfully superficial observation. The newcomer to a coral reef, the tourist diver, has, however, no Baedeker at hand from which to filch values and ideas. To remove one's helmet spells death, but in other ways the most blase observer must somehow feel and show the awe which is inspired by his first few descents.

I had dived many times in Cocos and Galápagos waters and there I found myself always in a background of somber, purgatorial aspect,-mighty masses of dark lava and volcanic outbursts setting off the procession of thousands of gorgeously colored fish. Here in Haiti, the surroundings were of equal brilliance with the living, moving inhabitants, and adventure and activity so omnipresent that hundreds of descents have still left me with ability only to present separate vignettes, individual mosaics, which future study will mould into more accurate appreciation of the life of the reef as a whole.

My favorite method of going down, when the bottom is only three or four fathoms away, is to discard the rope or ladder and, balancing carefully, to sink direct. It gives a delightfully terrifying effect of falling slowly - the realization of a nightmare dream which ends safely.

My first Easter dive landed me on a large mound of brain coral, cracked in the middle, not by frost but very likely by an earthquake. I revolved slowly, feet close together, like some weird representation of the North Pole on top of the worid. 


\section{NO-MAN'S-LAND FIVE FATHOMS DOWN}

The wall beyond visible distance precipitated a score of smudges which darkened and finally crystallized into a school of purple-finned surgeon fish, accompanied by three angels, quite new to me.

A great moon of jelly passed majestically, and its shadow, apparently of far denser substance than itself, swept across a sandy path beneath me, for a moment sending a starfish into total eclipse. Then a numberless school of tiny fish swam past and around like a swarm of twinkling cometlets. A mighty grouper sneered up, rolled his bulging eyes up at my stream of bubbles and backed away. Perfect quiet held for a time and then a spotted shark - the first one since Galápagosweaved around a maze of lacy millepores, saw me, hesitated, and went steadily on its way.

I slid to the sand and looked about, and as usual, it was borne upon me that no more imaginary Martian or prehistoric landscape could be imagined. Within sight were pebbles, boulders, cliffs, fields of heather, beds of ragweed and phlox, single plants in full bloom of chrysanthemums and forget-me-nots, as well as shrubs, giant ferns and mosses, and yet there was not a single strand of vegetation, of algæ even,-all were living animals. No change need be made in the most weird, most ultramodern of ballets, if the architecture and designs of undersea were copied closely; the only criticism being that of gross exaggeration.

I chose today to walk a few yards or half drift 


\section{BENEATH TROPIC SEAS}

slowly along, then sit quietly and watch a single sandy glade or coral castle for adventure. I selected a cushion of soft growth upon a coral stool and let my eye drown itself in the color all about. My attention kept going back again and again to a great font of a sponge. It was not especially striking in size nor of perfect symmetry, nor of unusual brilliance-a greyish violet as I remember, but it was satisfying, - a characteristic indefinite but very real, if only we will relax before things about us and let unimportantness fade away.

As I looked, my memory shifted forward and back and at last came to a rest upon the wonderful tale of the pursuit curve of the Greeks, the tractrix of which a great philosopher once told me. It was the ideal curve which had a definite beginning or start, but whose arc left no inkling of continuance or of exact radius. It was the pursuit curve, and to my joy as I thought of it in my waterburied, helmet chamber, I actually saw it enacted. A coral and a gorgonia had grown together almost at right angles and down the latticework swam slowly a small parrotfish. It traversed the side of the gorgonia and half the straight line of the coral, when there darted out from a diminutive cavern, just beyond, an infuriated butterflyfish. The latter was half the size of the other, but eight times larger emotionally, and, with sharp spines erect, it fairly flew in defence of its home. With a six-inch start the dusky parrot turned and 


\section{NO-MAN'S-LAND FIVE FATHOMS DOWN}

streaked for the most distant point in the world. But he was not versed in retreat and retraced his own wake to the very corner. The two little people of the sea were oblivious to everything except one another, but soon it dawned on the parrot that he was racing into a cul-de-sac, and putting his tail hard a-port he swung out, thus avoiding the sharp angle of the coral and gorgonia, and setting his course toward the center of the sea-fan. The butterflyfish, a short distance to the rear, at once followed suit and both soon vanished from sight, but not before, five fathoms deep, they had re-enacted the two soldiers fleeing along the walls of Troy. Here, in mid-water was drawn for me, the wonderful tractrix itself, and now my eye wandered back, and it seemed very reasonable that it was the lines of some similarly marvellous curve which gave solution to the eminent satisfactoriness of the great sponge font before me.

I was still in the canyon of brain corals and leaning upon one, I could look across at a half dozen others, appearing for all the world like a cluster of African huts in a tree-shadowed kraal. The wandering lines and paths of this well-named Mcandrina coral recalled the furrowed, rainworn gullies and terraced slopes of the western Himalayas. From the crevices between mounds sprouted tall, waving shrubs of horny coral, seaplumes, not only aping vegetation but reversing the manner of plants. One long branch which waved across my helmet-glass was deep furred 


\section{BENEATH TROPIC SEAS}

with thousands of dull, mouldy-brown polyps, aligned along the stem. At a touch from my hand all vanished and revealed the clear, bright purple of the bark and trunk. Sea-fans waved less pliantly, like starched portières, or like English fruit-trees broken away from their flat garden walls. Many of these showed parasitic growths among their branches, mistletoe-like, sponges and shells and tall stately hydroids.

Here and there on the brain coral mounds sprouted little, double-spiralled worm pagodas, and over the tan surface slipped small, blue-lined gobies. Unnamed monsters slid over the horizon, more bizarre than any dragon of old on ancient hillside of fable.

At my very elbow a pagoda worm expanded. On the rear side of the summit of the creature was an absurd bit of flat mother-of-pearl shell with several strands of sea-weed growing from it-a defect, a disease perhaps, or a bit of broken shell from some snail entangled in the tissues of the worm. Aside from this the gorgeous gills were perfect and symmetrical. The piece of extraneous matter annoyed me; it was as meaningless as the ruff of a sleeping golden pheasant, or an undeveloped photographic plate of the Taj Mahal.

In this land miracles can be worked with a shadow, and my hand passing between the sun and the worm sent the whole affair hurtling undercoral. The defect now became perfection. Nothing was visible to the onlooking eye but a 


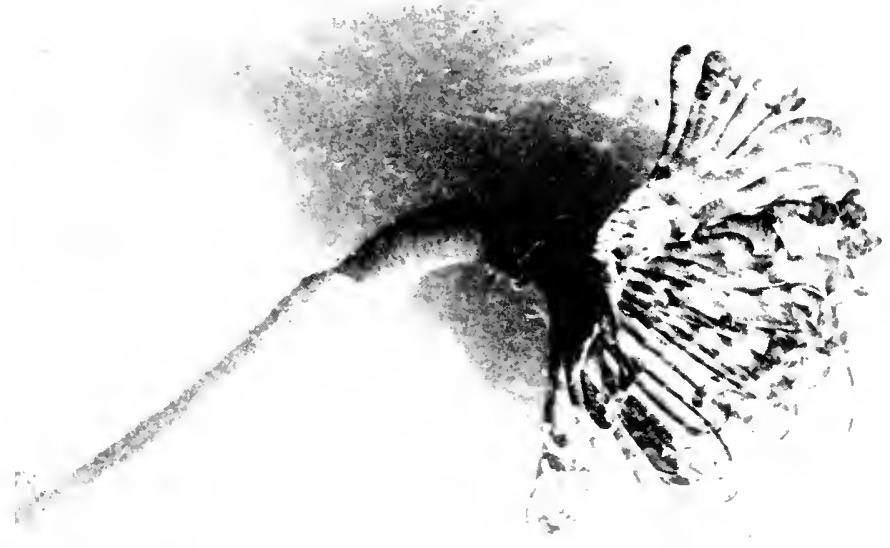

Tube-living Sea-worm

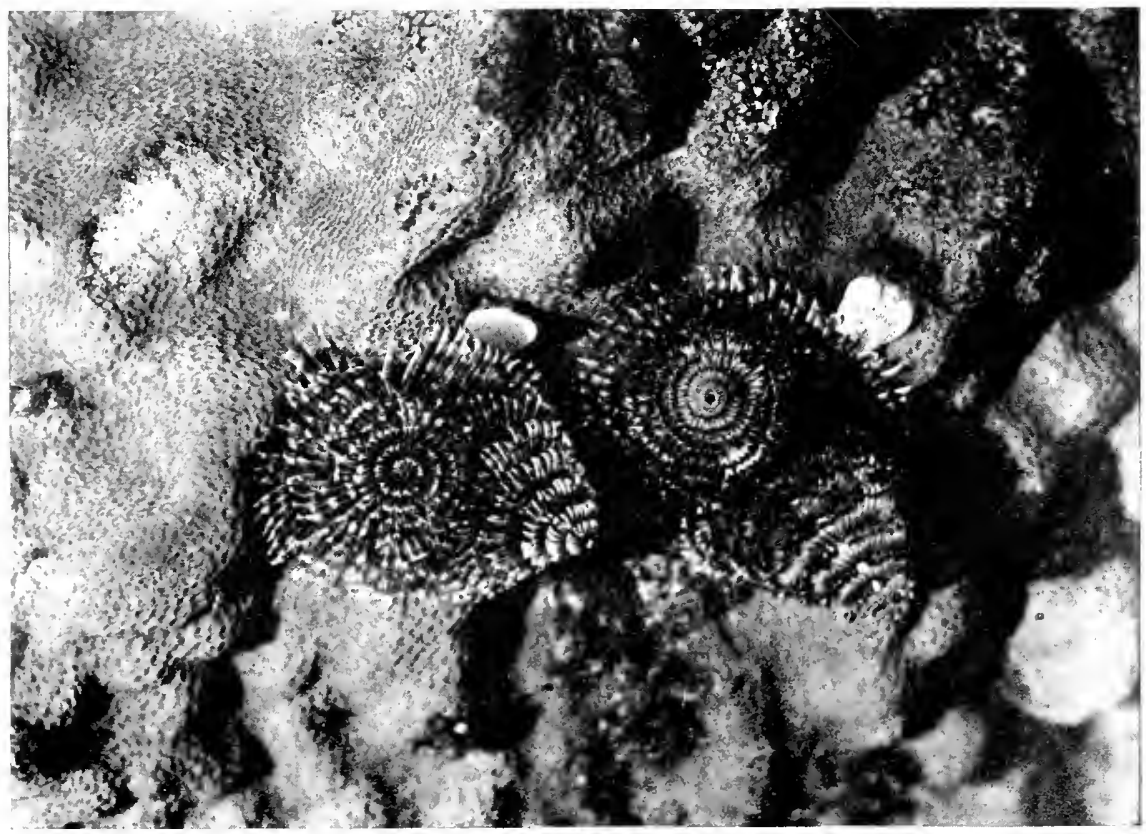

Yellow and Brown Sea-worms, Spirobranchus tricornis, Growing in Coral, Showing Mother-of-Pearl Trap-doors, Ready to be Closed Down 


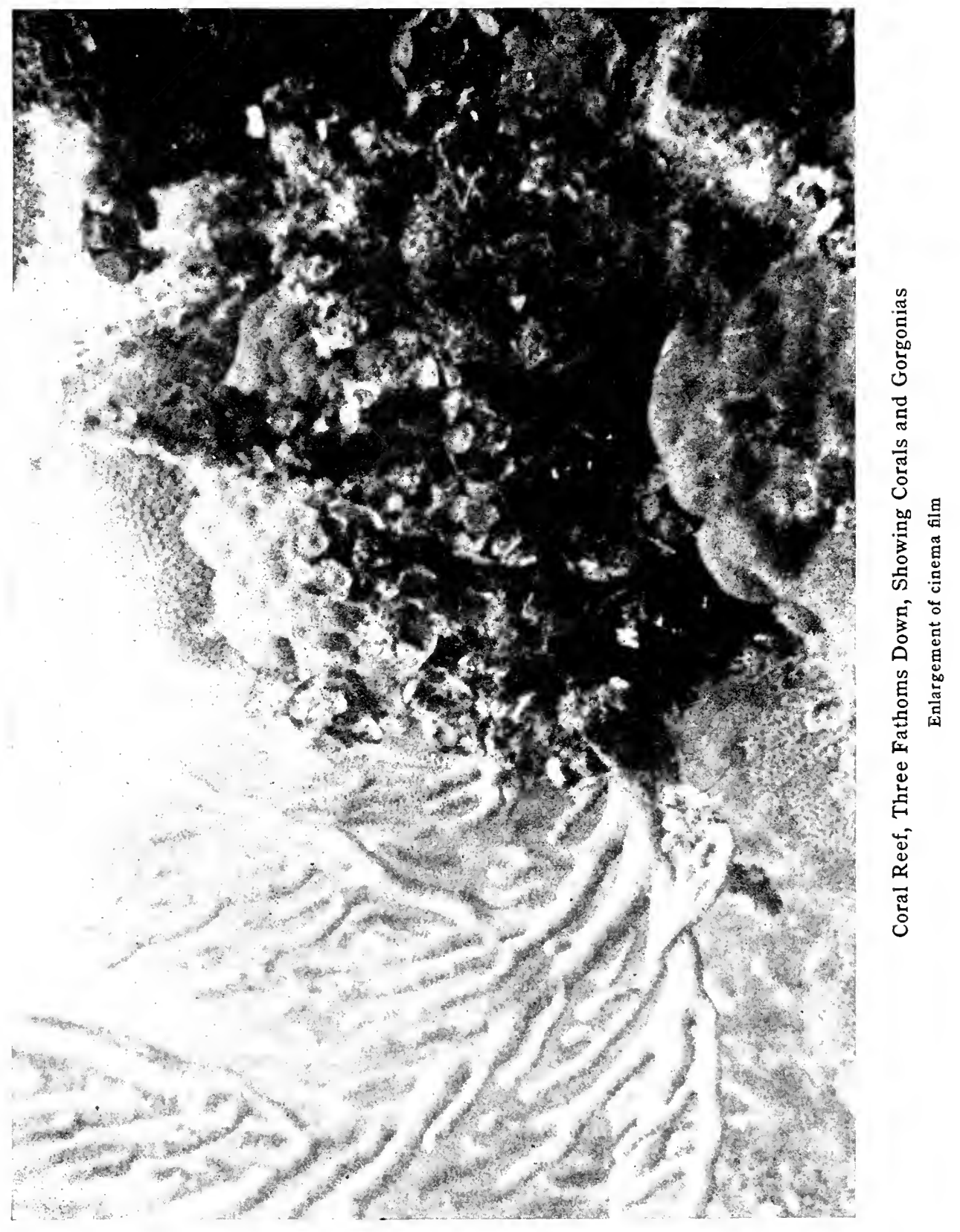


few casual strands of sea-weed, duplicated in a hundred neighboring places. The thin plate of nacre had been drawn with lightning swiftness after the vanishing worm, and dove-tailed exactly into the entrance of the narrow tunnel. We may now compare it more logically with the operculum of a snail or the trap-door of a spider's nest. Rather I chose to think of it as some secret entrance, where the cunning touch of a spring rolled away a boulder and displayed the silver stairway to a fairy palace. Here in the midst of the East End of Polypdom, typifying in their eternal monotony of meanderings the socialistic, standardized equality of the coral builders, was the winding palace tunnel with its silken-smooth lining of mother-of-pearl, and its aristocratic inhabitant of forget-me-not blue. The whole was only another under-sea "Exile's Club"; a submarine glimpse behind the looking-glass-this time of the flower going back within its stem. Lest this momentary flight of fancy should seem to dominate our vermiceous emotions I take occasion properly to introduce this worthy being as a member of the order of Polychate worms, branch Cryptocephala, sub-order Sabelliformia, family Serpulido, and species Spirobranchus tricornis. Its maroon and buff clusters of gills, which seem also to serve as sensory organs, are one of the commonest objects to be seen scattered over the surface of the great coral heads.

Leaving my comfortable cerebrum coral mound, 


\section{BENEATH TROPIC SEAS}

I moved slowly away toward an open field of tube sponges,--factory chimneys coming to mind with unpleasant vividness-and others which to my terrestrial eyesight, recalled vases, chalices, cups and ewers. I was impelled to engage in my favorite under-water sport of sponge stuffing.

Before diving I had tucked a large wad of absorbent cotton inside my belt and, with my knife loosened in its sheath, I now pushed through the water, leaning heavily as though against a strong wind. Soon I saw the black gaping mouths of a colony of sponges, and finding the leeward side of the current, I crept up slowly and shifted my helmet so that I looked out through one glass only. When I pulled out the cotton I was held for a moment by its beauty and the similes it brought up. Cotton in the air is heavy and gross. Tossed up, it drops to earth more directly than a leaf, but in water it becomes a thing of marvellous beauty. I involuntarily looked upward, but the ceiling of the troubled surface barred my view, and there was only the absurd keel of the motor boat rolling slowly about. What I looked for was a fleecy cloud, for that was the exact counterpart of my handful of cotton. I found another new characteristic of cotton in my watery element,cotton gravitation was almost suspended. I launched it in mid-water and there it stayed.

I tore off a bit and stuffed it into a finger-sized sponge, then reached for another, but the whole cloud had blown clear out of reach. Two seconds 
later the swell brought it back to my elbow and now I stuffed my sponges rhytlimically, one to each sway of the cotton. Once the swing was broken and to my dismay my cloud acquired a new rhythm of its own and sailed off with a myriad trailing strands. I pursued, caught it and found that a jeliyfish, so transparent that it had passed unseen close to my eyes and collided with my wad of cotton, pulsated deeply within its tissues,-when cotton cloud became mobile jeily forthwith. I shook the jelly free, leaving a host of tiny tufts adherent to its tentacles, to aid or impede its future path of life.

Returning to my work, I pricked my finger on an urchin's spine and involuntarily jerked my sponge bush, whereat a tiny, lithe fish darted out, up to my helmet, looked in, and slipped back into the sponge between my fingers-all in an instant of time. I rammed the cloud plug after him and gently began to pry the colony loose.

At this instant I saw a new thing - an absolutely new thing to me-something in which my years of study of ocean forms of life helped me not at all. It was floating in mid-water, oval in shape, surrounded by a band of waving fin, while hanging down in front were two strange appendages. I left my clump of sponges, slowly gathered up the cotton cloud and crept after this phantom. I gained on it, and saw two large eyes. Then it shifted its backward progress, swerving about a branch of coral and, from the side, my monster became the foreshortened body of a great squid. 


\section{BENEATH TROPIC SEAS}

With the magic of sea things, he was floating gently in mid-space, keeping just out of reach of my itching palms, and scarleting and palliding as nothing can in the world but a squid. I stood upright and looked down. All his arms stretched out for an instant in my direction, and out of the transparency of the waving fin there slowly grew two more eyes, eyes more terrible than his real staring orbs, because of their very unreality and brilliance. They seemed to gaze stolidly, unemotionally at me, until suddenly the apparition changed appallingly, and heavy, shaggy eyebrows appeared,--eyebrows meeting in mid-brow, where yet there was no brow, - scowling straight, unblinkingly. The lids and pupils - all were clear and distinct. After they had looked at me for a space of time which might have been a second or a week, they gradually faded away,- - no whit unlike Alice's cat, and the tail fin of the squid showed again, white and unmarked.

I pursued some way further, until the path was too becoraled and sea-urchined for careless walking, and then I returned to my sponges. The cotton had worked partly out, the loose ends floating and drifting, and the chimney simile was heightened by this flaring smoke pouring down current from the mouths. This time I allowed nothing to interfere with my securing of the colony and started back for the boat.

The way was obscured and the ladder had vanished from sight, so I looked for the floating hose by which to set my return course. Without 


\section{NO-MAN'S-LAND FIVE FATHOMS DOWN}

warning there fell at my feet a good sized anchor and, looking up, I saw the keel of the schooner's big jolly-boat. I knew of no reason why this should have followed us, and so prepared for a return signal along the hose. None came, so I went on and stumbled over another beautiful clump of sponges. No landscape gardner could have improved on the exquisite combination of colors and forms. There was a semi-circular border of stone-grey, soft-spined sponges, while within there rose three beautifully moulded vases, two tall and symmetrical, one shorter and gracefully bent, of the sheerest violet, the sponge tissue frosted over with a delicate mist of shining crystals. Two of the grey tubes had variegated flower worms blossoming in them-like glorious lilies in drab flower-pots, but while in the latter case we have living plant and dead clay, here it was animal and animal.

As I was following back my meandering hose, a tall human form passed over my head, swimming swiftly from one boat to another. With its head out of sight above the surface it offered insuperable difficulties to identification. Suddenly its face appeared below water and I recognized Dr. Alexander Wetmore, the head of the National Museum. I hastened up the ladder, for he had come at my invitation and I knew he was anxious to use the helmet, and to get at least a glimpse of this under-water world which is such an old story to penguins and ouzels. 


\section{CHAPTER V}

\section{WATER'S-EDGE IN HAITI}

I had dived deep beneath the waters of Haiti; I had climbed her mountains, horseback and afoot, but I had not stopped halfway and looked with any attention at the shore. I doubt if there is really any more dramatic place in the world than 'tween tides. We usually pass it by with a comment on high or low water, but if we will lie flat on our backs just above high tide (because of our unamphibian infirmity) we may see miracles.

I picked out a clump of trees above a white beach half a mile from the schooner and rowed thither. They were my old friends the mangroves-the red kind, Avicennia-whose roots by the thousand kept saying "thumbs up." Back of a sandy strip of beach I found an old boat sinking into the elements of all boats, and climbing in I waited. In five seconds a great cuckoo fell into my lap, thrashed out again, leaving two tail feathers, and flopped up into the branches overhead. Over all the world cuckoos are remarkable for two thingsthe astounding quality and diversity of their food and the difficulty they have in making their wings and tails behave. This was the great lizard-eating 


\section{WATER'S-EDGE IN HAITI}

cuckoo of Haiti and in his pursuit of saurians he was as regardless of direction and feathers and ultimate balance as his ebony cousins the black witch cuckoos, who, at this very moment "whaleeped" in an adjoining thicket. While he preened his remaining feathers I stuck my mementos in my helmet and waited for my next Haitian adventure.

Solitude is impossible in this human-ridden land and I could hear the soft French patois of blacks working in the sugar-cane behind, while on the reef before me two men bailed their leaky boats almost all the time, and in brief intervals of safety examined their wicker fish-traps and stabbed sea-urchin bait with nails on long poles.

The right of present possession and force of concentrated interest having made this my very own beach, I leaned back with a feeling of contented ownership and watched for all comers. The first was a slender beauty, a shadow-thin Louisiana heron which paced slowly past in the shallows, eyeing my boat with suspicion, but paying me the compliment of not distinguishing me from the surrounding rotting boards and lichened roots. Once he stopped and snatched a tiny, flickering fish and again pecked vainly at a dark spot which I knew was a live conch. Then he spread his wings and left my beach without sound or track. My next visitor was a trespasser, a IIaitian, halfclad in a garb of filthy rags, unwashed and unpleasant. Shining through these was the most beautiful copper mahogany skin, perfectly temp- 


\section{BENEATH TROPIC SEAS}

ered to this tropic sun and air, infinitely more modest and sane than his hopeless attempts at conventional dress. Clad as I was only in abbreviated swimming trunks, my fair skin would have been an offence beside his were it not that in two months of constant exposure I had attained the hue of a dark mulatto.

My Haitian also stopped at the conch shell, picked it up and, disentangling a rusty knife from his shreds of civilization he cut out a section of the mollusk and ate it. It was so natural a use of the beach and so skillfully done that I felt like withdrawing the stigma of trespasser and classing him with the native heron.

A mockingbird began to sing directly behind me and for many minutes drowned out the sound of human voices in the distance. My cuckoo croaked overhead and spat down berry pits into my landlocked boat. Then magic began in the boat itself. The bottom boards had long since rotted away and I sat on a mat of dry mangrove leaves. As if at a signal these leaves began to shift and lift and rub noisily against one another like recently crumpled papers in a waste basket. The morning breeze had not yet sprung up and I sat waiting for the elves which haunt old boats. In half a minute a dozen fiddler crabs bustled forth and, with one impulse, immediately vanished. I was comfortably frozen and had not frightened them, but the actual cause was as satisfying as the sight of the crabs themselves. A small green cockroach flew 


\section{WATER'S-EDGE IN HAITI}

into the farther end, and after it, pell-mell, two of my countryfolk, a parula warbler and a Maryland yellow-throat. They sensed me, and, in spite of our common nationality, fled headlong with only a single chirp between them.

The tide was going down my sloping sand and on the uppermost ten feet I could read in the deep ripple marks the record of the strong wind which had whistled around our schooner tents at midnight. When I reached the five o'clock zone of calm, the sand's surface was smooth as paper. Nothing in the world seemed more certain than that in a few hours the returning tide would wipe out every ripple mark, and yet I recalled many fossilized beaches, some over a mile above the present sea, where the tide had never returned, where by some velvet convulsion of Mother Earth the delicate furrows of shifting grains had become solid stone.

Everywhere on the smooth sand were records, as clear as tracks on snow, of watery beings who were compromising or pioneering in this ribbon kingdom of dual elements-forever fought for by water and by air. The fiddlers were high up shore, pretending that they were land folk, yet never daring wholly to desert the dampness.

On mid-beach a few fiddlers were working like fury, digging tunnels and throwing up breastworks, piling pellets of sand with as perfect confidence as the foolish man in the Bible. Below them were scores of parallel lines drawn by terrified, little black snails all of whose bravado about the 


\section{BENEATH TROPIC SEAS}

land had evaporated with the water, and who were following their ancestral element with all the speed of their tiny muscled feet. One giant, a half inch in length, ploughed the distance of his stature in half a minute, and had therefore covered the eight feet of his back trail in an hour and a half, hardly the speed of the retreating tide. These jet-black, handsome, beaded turrets, speeding over the sand, were only a few of their kind-those which had been caught in the blazing sun far from shelter. Wherever a depression promised dampness during low tide, or where the cool, mossy, mangrove rootlets raised their spikes, thousands of the ebony spires gathered, spun a moisture-proof varnish across their front vestibule, and slept or dreamed or thought, or, perhaps being merely mollusks, only existed until the returning water awoke them to the joys and sorrows of snail life.

If I had ventured to make a probable list of the sea creatures most likely to be found among the mangrove roots at low tide I would have completely failed. I should have favored sturdy, strong-housed snails and hermit crabs. But here instead, were the flabbiest bits of life,-unpleasant, wormy sea-cucumbers which, as seen half-dried in the sun, not even an enthusiastic Holothurologist could call attractive. Their claim upon our interest, as I have shown elsewhere, is quite another matter.

Here in the sandy mangrove zone I was surprised to find sea anemones. I came across a symmetrical 


\section{WATER'S-EDGE IN HAITI}

impression as if there had rested upon the sand a glass tumbler with base cut into an intricately scalloped pattern. As I stepped closer, the whole circular area sank a little and a touch identified it.

All around was the evidence of considerable wave action, sand ripples an inch in depth, and it was hard to understand how this bit of flaccid animal jelly could maintain its hold upon the shifting grains. With my penknife I began excavating on one side, going down and down until at last I located its foot on a horizontal mangrove root eight inches below the surface. When I dislodged it, a thick sheet of the red bark came along with it. I was reminded of the mixed character of this zone of life by a cohort of stinging ants which raced over the sand and occasionally nipped me as I dug. The type of mind which is thrilled by having picked oysters from trees could make an excellent Haitian yarn from the juxtaposition of anemones and ants. As I labored, a green and brown lizard dashed past in pursuit of the tiniest of fiddler infants. This astonishing race resulted in success for the aquatic kingdom when the crablet dived safely into its hole.

By the time I had freed my anemone it had contracted to two inches and looked like a sandy mushroom. At first glance there was little to choose in point of beauty between it and the nearby, stranded sea-cucumber, but washing worked wonders, and the cucumber changed to the semblance 


\section{BENEATH TROPIC SEAS}

of a rolling field all aglow with a dense crop of tansy in full bloom, and the moment I planted the anemone in an aquarium of sand, things beautiful began to happen.

Balanced on its contracted base, it gradually commenced to flatten and to grip the bottom with long, bulbous furrows. The summit opened slowly like the delayed motion picture of an expanding flower. Structure after structure came into view, none showing the brilliancy of those blossoming on the coral reef a hundred yards from shore, but very beautiful with the exquisitely subdued patterning of hen pheasants. First there uncurled a broad Elizabethan ruff of clove brown, revolving outward in an expanse of surface like lace spread over a ploughed field. Then, like rabbits and bouquets from a conjurer's hat, from no space at all, rose up rank after rank of long finger tentacles, until forty-eight were numbered. These were thick at the base, and pale misty olive with scars of whitish scattered down the inner side. Within the three circles of the ever-moving tentacles was a flat field of olive, marbled with reddish brown, guarding in its center the half-opened mouth, with still concealed, inner organs showing as four pearly spheres.

The first two anemones which I excavated had columns of pale pink, the exact shade of the bark of the submerged mangrove roots, but even the most violent protective colorite could derive no support from this pigmental by-product, for in 


\section{WATER'S-EDGE IN HAITI}

the next two anemones the long stalks were green.

Although they move and eat and are animals like ourselves, anemones, as personalities, pall after a time, and my interest was about to shift to other organisms when, in the lee of a small mangrove growing far down the sand, I saw a large individual with a brood of young alongside. There were eleven, and all clustered in a squarish space of about three inches. Their discs were tiny but the slender tentacles were bravely expanded to their widest extent.

Sea anemones are delightfully diversified in the matter of reproduction. The eggs may be fertilized in the water or be retained until they become good sized embryos. Some actinian mothers have special brood pouches like aquatic kangaroos. Or adventitious infants may suddenly develop like buds on the stalk of the parent; or the anemone herself may have a sudden longing for a double life, and slowly and gently split in twain, either horizontally or across.

It would almost seem as if the small family I had discovered had dropped off as buds, and instantly sunk their tiny, living shafts to bed-rock, or in this case bed-shell, for all reached down a full inch to a long buried wreck of a conch. To this they clung with a persistency resisting the movements both of sand and water, - which to them were, on the one hand avalanches of great boulders and on the other, the terrific pounding of huge breakers. 


\section{BENEATH TROPIC SEAS}

Thus did one family of Haitian sand anemones or more accurately, Asteractis expansa, start their lives on my beach.

About six o'clock one tropical winter evening, a disgruntled mother fiddler crab kicked several hundred of her offspring into the sea. Most of them soon died, some being eaten, others tangled up in the drifting sea-weed, or thrown ashore and thoroughly dried. One at least lived, and today on my beach, a year later, I watched him come out of his burrow near the bow of my dessicated boat. I state all this with assurance because it is the manner of birth of all fiddler crabs. For many days the mother crab carries dozens of bunches of eggs around with her. They are so heavy that she fears to leave her burrow except at dusk. She has little or no warmth of affection for them and only through instinct is moved nightly to wade into the treacherous shallows and flick her growing offspring about,-thus aërating them.

One evening, invariably about dusk, the young burst their shells and at every flick of their mother's body they are scattered by the thousand throumt the water. They bear exactly the same amoun of resemblance to their parent that a horned toad does to a pussy cat. The head and thorax part is enormous and is made up chiefly of two long spines and a pair of monstrous eyes. A slender string of five beads forms an abdomen of sorts, and two small oars project at the sides, whose blades are tufts of feathery hairs. Twenty- 


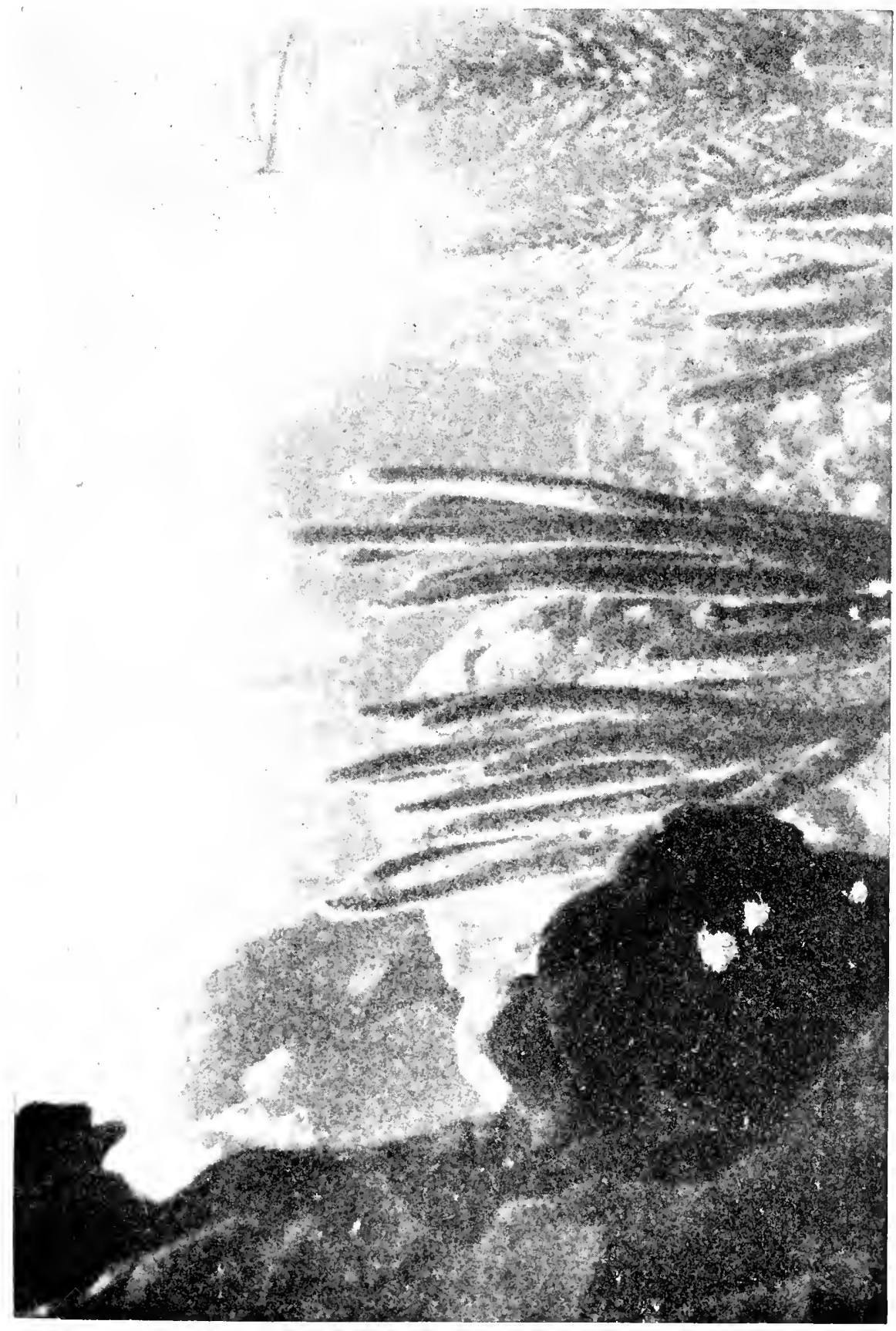

龒

ติ

㤘

음

胥

๗

సี

응

돈

焉

E

空

คำ

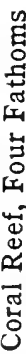




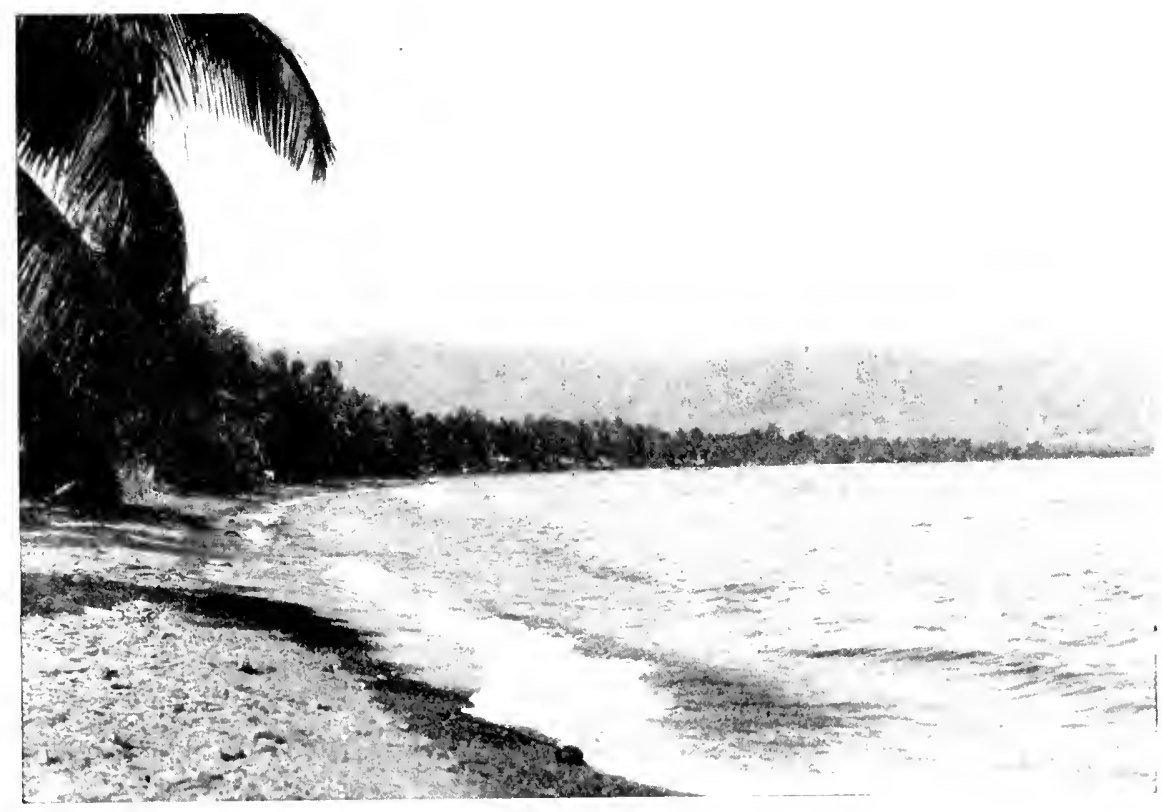

Water's Edge at Bizoton

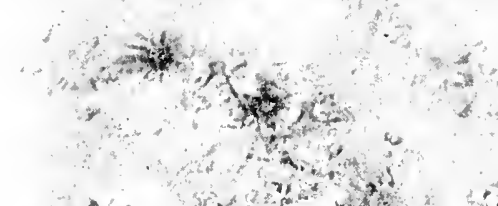

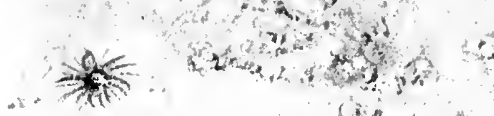

Sand Anemones, Parent and Young, Asteractis expansa 


\section{WATER'S-EDGE IN HAITI}

five of these uncomfortable, unreasonable little beings could line up upon a pin's length.

Our infant crab lives the simple life, in fact it is the simple life even to its name, Zoëa, which in Greek means Life. The whole object of Zoëa for many weeks is to row itself furiously along, onward and upward as near the surface and light as possible, and to clutch at creatures still smaller and devour them. It kicks itself along through a whole world of infantile life-all at the mercy of waves and tides and currents. There are seaworms, sea-urchins, snails, jelly and starfish, mossanimals, sea-eggs, larval fish and lobsters-all youthful, free-swimming, boiling with futile energy, kicking, snapping, wriggling and flapping their way through the water in preparation for the time when age shall force most of them to settle down to a life of crawling, creeping, winding or even vegetative existence on the bottom of the sea.

With and about and around all these tiny creatures drifts still another world of life-billions upon billions of one-celled animals and plants. And were we of sufficient lack of stature to observe these adequately, we would be hard put to it often to tell which was plant and which animal; such easy marks of difference as green coloring matter and lack of movement are meaningless here. We are in a strange cosmos where no second glance would be given to a geranium with wings or a puppy with roots. This third world furnishes an abundance of nourishment for the second which 


\section{BENEATH TROPIC SEAS}

is that of Zoëa. And Zoëa crumbs fall from banquet tables of the fish fraternity and so on.

In the matter of privacy the famous goldfish lives in an opaque seraglio in comparison with Zoëa. The latter is absolutely transparent, and nothing is hidden from friend or enemy,-the heart, beating sometimes fast, sometimes slow or stopping, the food going cheerfully on its way through the body, while we can see the muscles move as behind clear glass.

For a few weeks Zoëa succeeds in keeping near the surface, but as it molts again and again, its oars are blunted and it gets heavier, until it gives up and rolls about helplessly on the bottom. The fifth Zoëa now molts into a being somewhat awfully like a crab, but one misshapen and gone all wrong. It is as horrible in disposition as in bodily form. Megalops it is called, and it claws its way through the water, feeding voraciously. Its own brothers and lesser Zoëa nephews are especial titbits. Another month passes while the crab spirit grows stronger and for a week or more it clings to floating nuts or weed or bits of wood and at last crawls unsteadily out on land. Here it is probably devoured by its father, mother or relatives, for it is still only a twelfth of an inch in length. If however, it runs the gauntlet, it digs a tiny burrow and for the first time in its life has a short, safe breathing space.

When it molts into one-eighth inch of crab, it observes with interest (or should do so) that one of 


\section{WATER'S-EDGE IN HAITI}

its front pincers is larger than the other. It is easy for us to imagine how exciting it must be to watch one's figure alter after each molt; to hold up one's hands and see one of them growing larger and larger, while the other stays unchanged. It is fortunate that at least one remains unaltered, for the great claw is more in the way than it is useful. While the body of the crab is dark grey, exactly the color of damp sand, the enormous claw is of a conspicuous ivory-white.

If a man of average size and weight changed a pair of mittens every week, and developed along the lines of a male fiddler, his hand would finally measure ten feet in length and weigh sixty pounds. With such a handicap (no pun intended), he would surely have trouble at a lunch counter.

Day by day now, the growing fiddler leaves its burrow and follows the tide up and down the beach, feeding on all the flotsam and windrows of dead and living creatures and the algæ manna spread twice a day by some benignant god of fiddlers. If our crab is hungry, he must envy the lady fiddlers who shovel the food up with both hands, while he must lug the great claw about, and ply his single little spoon as best he may.

Our fiddler, whether right or left handed, is now finally started upon his way of life. Up to this time he has been the plaything of wind and wave, tossed and tumbled about, snatching at whatever bits of food fate sent him,-with as much conscious will and power of choice as a rolling stone. 


\section{BENEATH TROPIC SEAS}

Now he builds him a house and although it is founded upon or rather in the sand, yet for him henceforth, the stars revolve about the entrance to his burrow, the sun shines only upon it, the tide rises merely for the purpose periodically of dampening it. Then one day I appear-a most unimportant shapeless intrusion-harmless and disregarded if I am quiet, something to be avoided if $I$ move.

I can take no conceit for this, for all his cosmos is divided into two parts,-things harmless, and things unknown and therefore probably harmful. First are the darkness and the sunshine, the wind, the rain, the rising tide, and all quiescent things. A heron-a hungry carcinophagous (look it up, it's a good forthright sounding word) heron-who has the patience to imitate the immobility of his likeness on a Japanese screen,- such a heron is but a spindling bush, or is not at all, to the fiddler peering out of his burrow. But if the bulging eyes of the heron so much as wink, if the smallest muscle gives an anticipatory twitch, the spindling bush becomes what it is,-a cancrivorous (you may like this one better, if your forebears came from Rome instead of Athens) horror. It may then stand still till doomsday, and the crab will remain in his burrow until a few minutes after that time.

Immediately the morning sun has boomed down the Valley of the Cul-de-Sac and set fire to Portau-Prince and the waters of the great gulf, my fiddler peers out from behind his plug of earth- 


\section{WATER'S-EDGE IN HAITI}

his barricade against unknown and therefore imminent dangers of the night. He pushes it aside and stands aloft beside his burrow. The new day dawns for him alone as far as he knows, and three problems await him; he must avoid danger and death, he must seek and find food, and he must detect and secure a mate to insure future offspring. Not being a self-conscious "higher" animal, he may avoid none of these sacred responsibilities.

It was at this moment that I settled down to a comfortable position within my decayed and stranded craft and watched him over the crumbling stern-post. A small flock of blackbirds dashed past the mangrove tree over my head, and the fiddler dived side-ways into his hole. I stretched out my hand, rested the tips of all five fingers on the sand and waited. Soon the tip of an eye-stalk appeared and then all of it, and the fiddler was above ground again. He surprised me now, for after only a few seconds he walked on toe-tips to my thumb and gently nibbled it with his small claw, then strolled around and between my fingers. His sense of sight was apparently the dominant one, for the odor of my hand, and as I subsequently found, even the roar from a shotgun, conveyed nothing. It is difficult to study fiddlers seriously, they are so comical in their appearance and motions and so absurdly like human gnomes, and yet the slightest smile or laugh will send them headlong. Whenever my fiddler came out from his burrow 


\section{BENEATH TROPIC SEAS}

he cleaned himself carefully, wiping off every fleck of sand from eyes and whatever parts of himself he could reach.

A file of fiddler brethren passed and my crab raised aloft and brandished his great claw-broadsword, battle-ax, mammoth shears,-all similes fail. He was answered by every male in sight and a youngster ran up and made one or two passes at him. The ebbing tide was lapping a yard or two away and all the host gradually made its way down to the water. With eyes on high, the little chaps worked at feeding with might and main. They simply spooned the mud into their mouths and there made selection of edible morsels, or with the tiny forceps of the small claw picked up bits of seaweed. Once full retreat was sounded-a false alarm, for one crab had seen another frightened by some youngster down the beach who suddenly caught sight of a small hermit crab bumping along peacefully enough, and fled headlong-doing whatever crabs do instead of screaming.

My muscles rebelled at last and I sat up to ease them, and by the action sent every crab into its burrow. They even ran toward me in order to reach their holes. All was quiet for the space of two minutes and then the elves and hobgoblins appeared again. When the procession had fairly begun, I saw a new development. Every male in sight stiffened to attention, and lifted his great claw as high as he could reach. And down the line came a female fiddler. There were others 


\section{WATER'S-EDGE IN HAITI}

of her sex in sight, some larger, but this particular one worked magic. The frantic gesticulating and waving on all sides would have stirred any blasé movie queen to appreciation. Food and danger were forgotten. The only thing in the world was to get one's ivory-white claw noticed, and then gently to persuade Her to enter one's burrow. The action was that of a mighty gesticulation, a beckoning in five jerks, the last of which almost threw the crab over on its back. When all the male crabs in the colony were suddenly seized with this frenzy of persuasion, the distant view was exactly like that of a mob of cheering human beings, the simile being all the more remarkable because of the desperate and complete silence which clothed the emotional outbursts of these crustacean citizens.

The difference between this gesture of the right hand of passionate fellowship and that of shaking the fist in the face of any passing male, was hardly to be discerned. In the case of the courtship the fiddler would often freeze into a statuesque pose for three or four minutes at a time. And if any man sneers at fiddler crabs because they are inedible and hence unworthy of notice, let him try to hold a sixty-pound weight at arm's length. The crab's record is ten minutes.

My Haitian fiddler crabs were christened sixty years ago by a certain Dr. Smith, who called them Uca mordax-from Uca, a native Brazilian name, and a Roman's appreciation of their pinching 


\section{BENEATH TROPIC SEAS}

and biting ability. Although a crab's sand burrow is his castle, and the most savory morsel or the charmingest fiddler wench can tempt him hardly more than a yard or two away, yet his race is widespread. Many times in past centuries his ancestors must have clung fearfully but tenaciously to floating trees and other oceanic jetsam, and drifted far and wide, for his brethren are found today from the Bahamas throughout the West Indies, clear around the Gulf of Mexico and on south as far as Rio.

In the course of ten visits I observed a noticeable increase in an acceptance of me as something not wholly inimical. I should dearly love to identify myself in the fiddlers' notions, as a swaying mangrove for harmlessness. I believe I should find more than the three basic problems. The courtship I think would prove to be more complex, and actual uses more apparent and vital for the huge claw,-twice as long and nearly half as heavy as all the rest of its owner. 


\section{CHAPTER VI}

\section{A TARPON NURSERY IN HAITI}

About fifteen miles west of Port-au-Prince, Haiti, along the shore of the gulf itself, are two, interconnected land-locked lagoons known as Source Matelas. I visited them first with General John H. Russell on the thirteenth of January in the hope of getting a few brace of ducks. At the last minute I put a small seine in the car in case any fish might be procurable. We had bad luck as regards ducks for there was only a quartet of bluewinged teal, and these left before we got within shot. Willets, Louisiana herons and yellowlegs composed the remaining bird life of the lagoon. Grey kingbirds and mockingbirds called and sang in the tops of the low trees, and grassquits and migrating warblers hopped about the underbrush.

The more western of the lagoons was a rounded body of water about one hundred yards across, on a marshy promontory backed by low, rolling hills. These were covered with the usual semi-arid vegetation, consisting of cactus, cereus and acacias. From the waters of the gulf the lagoon is separated only by a narrow dyke built up apparently by the action of the storm waves at high water. 


\section{BENEATH TROPIC SEAS}

I walked into the ooze at the edge of the lagoon and out into the center. There I found half a foot of mud and about eighteen inches of water. This was green and muddy but not slimy. It was impregnated with sulphur and the odor of this element rose strongly from the disturbed bottom. A few miles away was a constantly flowing sulphur spring, used for bathing by the natives, and this lagoon has apparently some connection with the same source of supply. This unprepossessing liquid was filled with innumerable small insects which, upon examination, proved to be waterboatmen (Corixidoe), both adults with handsomely variegated, yellow elytra, and young which looked at first glance amazingly like copepods. These have been identified as Trichocorixa reticulata.

I saw no signs of fish and was about to return to shore when Dr. Jamieson who was with me, protested that he saw a fish jump. Then something, distinctly not a water-boatman, nipped our ankles. This happened again, and I called for the seine. We had hardly commenced to draw it when small fish began leaping high to escape it. Closing the net we examined our catch on the shore and I found thirty-six tarpon, Tarpon atlanticus, ranging from two to eight inches. When I recovered from my first astonishment at seeing these clean-scaled, virile fish living in this sulphurous, stagnant pool, I examined the smallest for any hint of the leptocephalus stage through which it is assumed they must pass early in life. 


\section{A TARPON NURSERY IN HAITI}

Neither this, nor a later, much more thorough examination showed in these young fish any hint of such phase-even the smallest was as normal and perfectly formed as any six-foot giant of the Florida waters. This may mean only that the leptocephalid characters disappear when the fish are still smaller.

The second lagoon was absolutely barren of fish life, and a haul made in the shallow gulf water just outside the dyke of the lagoon yielded nothing but thirteen small puffers, Diodon hystrix.

My next visit to Source Matelas was on January twenty-third. This time there were several hundred wading birds about the lagoons, including willets, greater yellowlegs, herons, stilts and several species of sandpipers. Dr. Jamieson and I made a haul with the seine in the same place and secured a heavy load of tarpon. Tee-Van and Crosby took good still and motion pictures of the process. When we counted our catch on shore, we found one hundred and fifty-four of the young fish, from three to seven inches in length. One individual measured thirteen inches. It was a pure culture of tarpon, except for three small snook, Centropomus undecimalis. Several times as many tarpon as we took escaped by leaping over the top of the seine as we were pulling it, some of them rising three feet clear of the surface. We threw back all but the few which we wished to keep as specimens.

My third visit was two months later, after heavy storms had set in, on the twenty-first of 


\section{BENEATH TROPIC SEAS}

March. Birds were abundant, including a pair of black-necked stilts which we shot for specimens, a flock of greater yellowlegs, two great blues, four Louisiana herons and a half dozen or more coots, while a flock of eight blue-winged teal got up as we approached.

I found the lagoon dyke broken through, and the tide pouring into a three-foot sluiceway. A thorough seining of the first lagoon netted six tarpon, measuring from four and a half to seven inches, together with a two-inch snook. Ultimate hauls failed to secure another fish of any kind. A seine haul in the second lagoon yielded four small mojarras, Eucinostomus californiensis, recent emigrants from the open water outside. The water-boatmen were as abundant, and the sulphur smell quite as strong as ever, in spite of the infiltration of the water from the gulf.

The most interesting development of this last haul of young tarpon was that when we examined five of the fish in aquariums on the schooner, we found that there was something the matter with their eyes-a grey, translucent film clouding the tissue of the lens or the humor behind it, the aspect being wholly unlike the appearance of the eyes of the fish taken two months before. They seemed to be quite blind. Whether this affliction was connected with their remaining in the lagoon after the hundreds or thousands of their fellows had escaped to the open gulf can only be surmised. It could hardly have interfered with their feeding, 


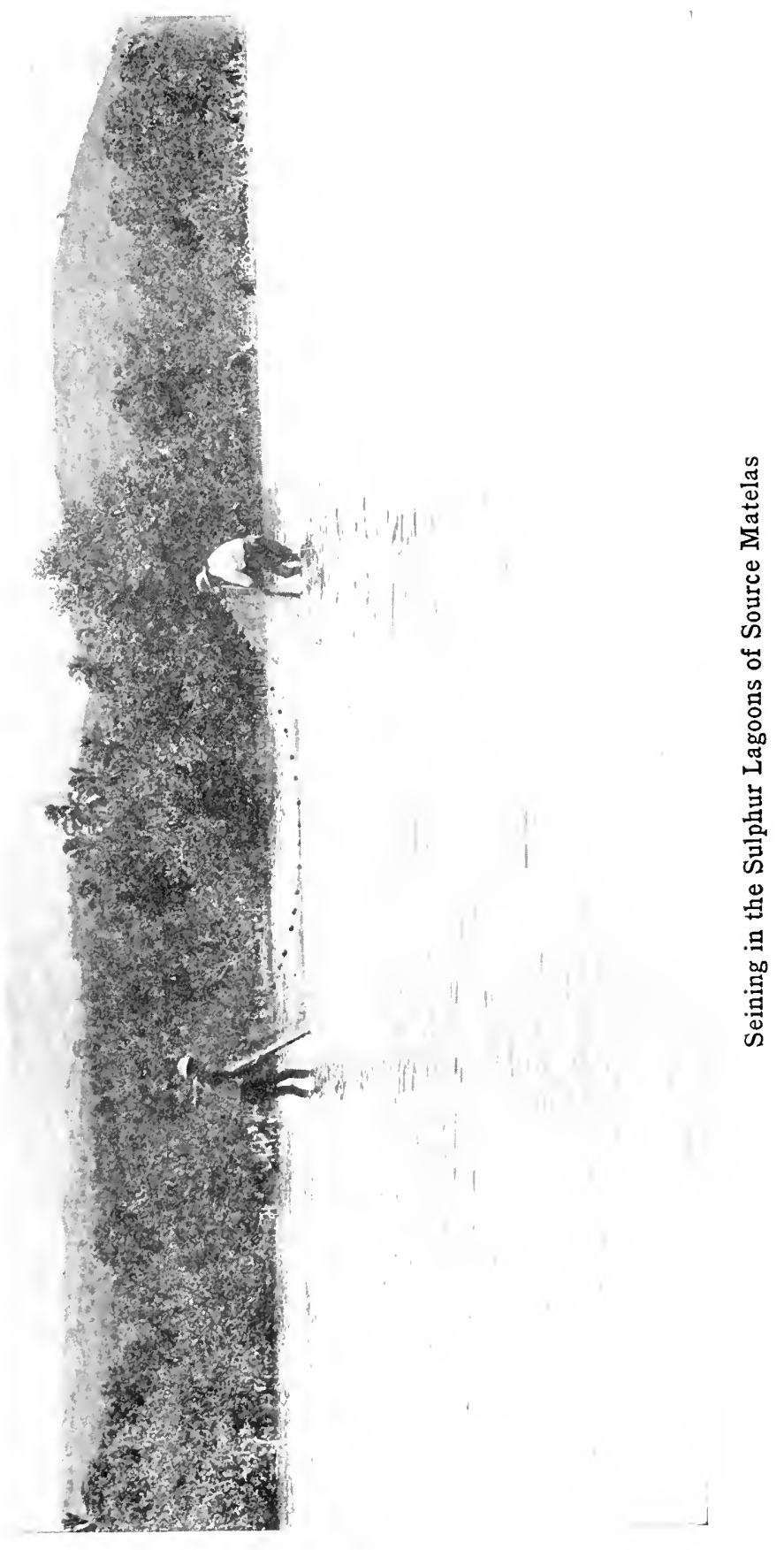




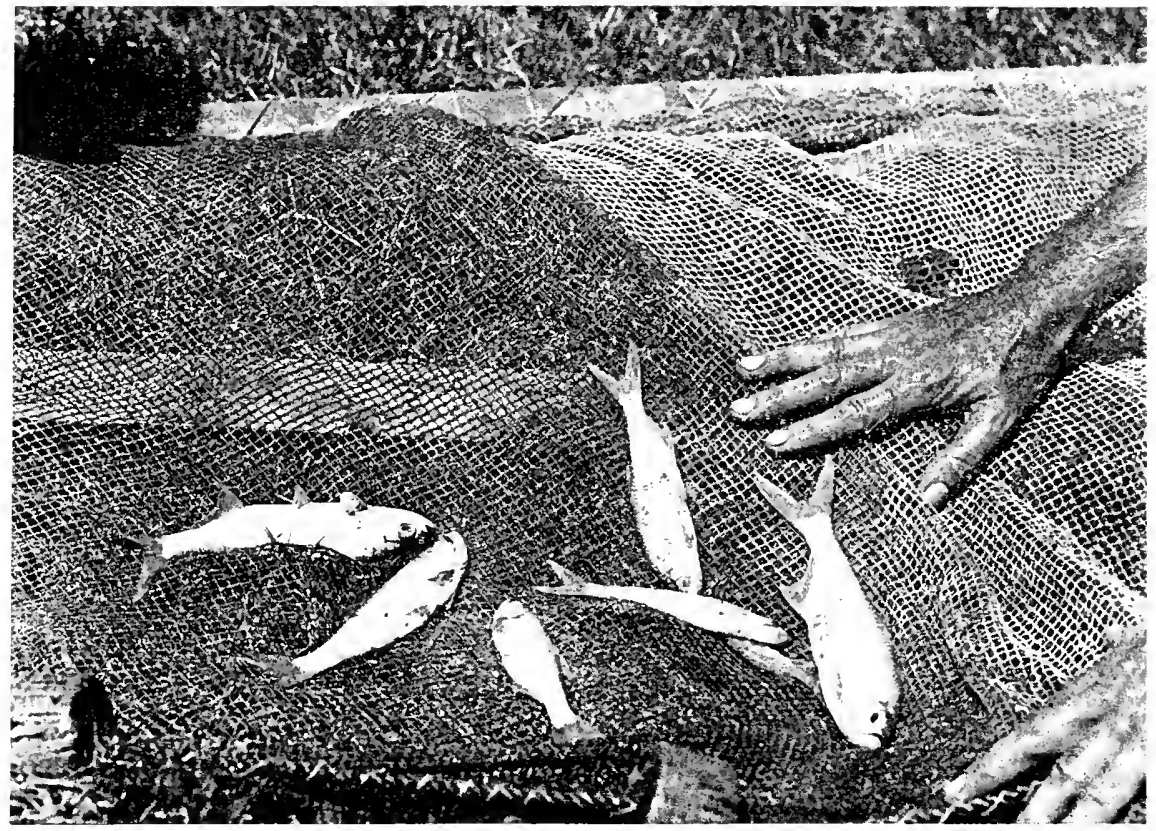

Young Tarpon Seined at Source Matelas

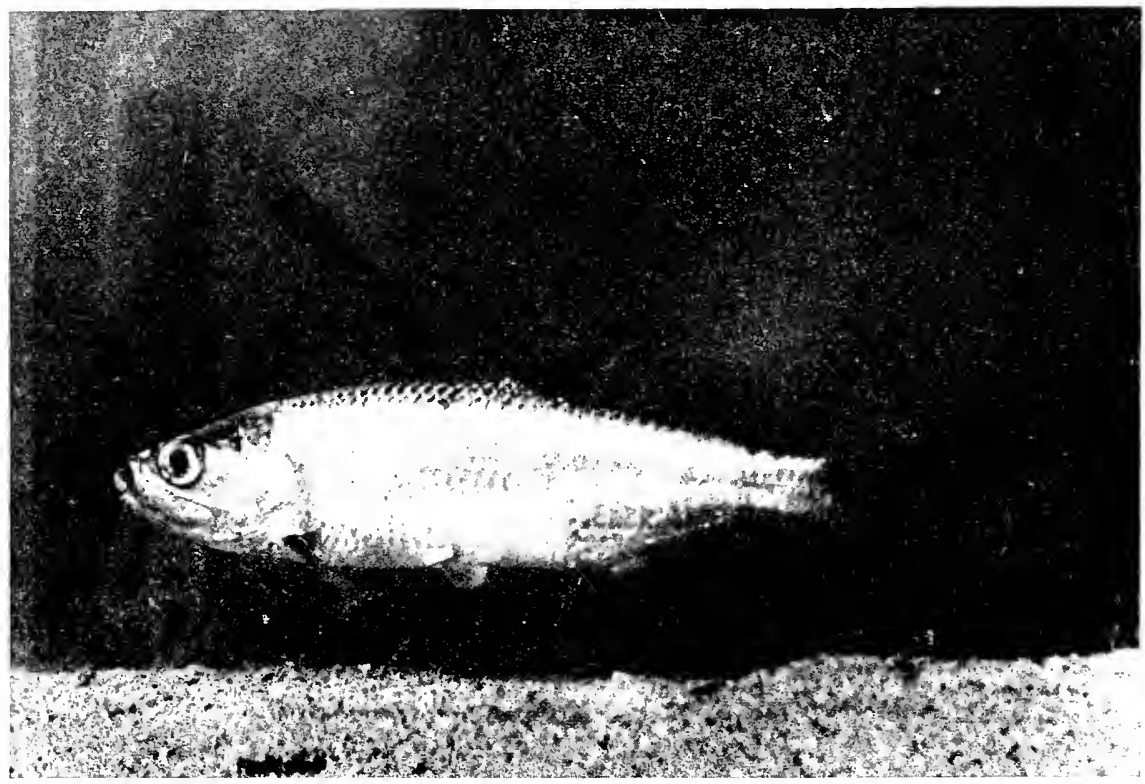

Three-inch Tarpon in an Aquarium on the Lieutenant 


\section{A TARPON NURSERY IN HAITI}

as the water-boatmen were present in uncounted millions, and a single scoop with a quart jar secured large numbers.

The only other mention of an actual nursery of tarpon is in Evermann and Marsh's Fishes of Porto Rico, where we find the following note: "Common about Porto Rico where it evidently breeds, as numerous immature individuals were taken at Hucares and Fajardo. The four examples from Hucares are from 7.5 to 11.5 inches long and were seined in a small brackish pool of dark-colored water, not over five feet deep, in the corner of a mangrove swamp, and at that time (February) entirely separated from the ocean by a narrow strip of land scarcely 25 feet wide. The thirteen others are nearly all very young, of 2.25 to 3.25 inches collected at Fajardo." A few tarpon, from six to eight inches long, have been taken on the north shore of the Gulf of Mexico in Florida, and Dr. Babcock in his excellent monograph of the tarpon, records a three-inch specimen taken in a cast net on the coast of Texas. He also gives the world's record tarpon as eight feet, with an estimated weight of three hundred and fifty pounds. This was taken in a net by a Florida fisherman.

My discovery of young tarpon in a land-locked lagoon in Haiti suggests that the Porto Rican record is not a casual accident, but a usual phenomenon in the life of these fish. On account of the shallowness and muddiness of the Haitian lagoon, it would be impossible for an adult tarpon of any 


\section{BENEATH TROPIC SEAS}

size to enter it and deposit her eggs. We can only surmise that the eggs are scattered out in the waters of the gulf, sink to the bottom and hatch, and that the young, either as leptocephalids or as very small larval fish, make their way into the lagoon before the season when it becomes cut off from the gulf. Here they live and thrive, with an abundance of food, sheltered from voracious fish and other dangers of the open sea, having to guard only against the keen eyes and sharp beaks of the larger herons, and such unthinkable catastrophes as visiting scientists.

Mr. Gray Griswold writes me that "There is a small lake on Den Island, San Carlos Bay, Florida west coast, that contains small tarpon. It is back of St. James City, has no inlet to the sea nor has the sea invaded it in the memory of man. It is supposed the spawn was dropped there by birds, or carried to the lake on the back of alligators. I have a specimen about seven inches long in a bottle. The posterior ray is fully developed on this fish as it was on a dead specimen I once picked up on the beach three inches long. I have taken them on a hook in Cuba not more than four inches long fully developed."

One of my Haitian fishermen took two goodsized tarpon in his seine not far off shore from Source Matelas. These were thirty-six pounders, more than forty-one inches in length.

When diving on Lamentin Reef, several miles across the gulf, I saw a large tarpon again and 


\section{A TARPON NURSERY IN IIAITI}

again. For a number of days in succession this great silver fish would swim toward me on my first submersion, and pass slowly within eight or ten feet, looking me over. When I learned that this would probably happen every time I went down, I devoted all my attention to estimating his exact length. Once he swam past two very tall tube sponges, and I could see distinctly that he overlapped the distance between them in actual body length, not including his tail. I measured this distance and found it six feet, three inches. So even ignoring the slight overlap, he was a full six feet in length of body. He showed no fear, only a gentle curiosity, rolling his great eye about as he passed. His scales reflected the light, even at a depth of twenty-five feet, as a dazzling sheet of bluish silver.

I could learn of no tarpon being caught on a hook in Haiti, although anglers have made many attempts. The native fishermen were familiar with them, and, as I have said, occasionally found them in their seines.

The food of the young tarpon consisted entirely of the aquatic hemiptera which filled the waters of the lagoon, a five-inch fish having the remains of sixty-eight of these insects in its stomach. The relative increase in various body measurements from a three-inch, through an eight-inch, to a fortyinch individual, is remarkably uniform, the average of the characters of length, depth, head and eye being $9.6 \%$, and $19.8 \%$, as compared with an 


\section{BENEATH TROPIC SEAS}

arbitrary $100 \%$ of the largest fish. The elongated, thread-like posterior ray of the dorsal fin is developed relatively late in life, the percentages of this character in the same three individuals being $2.7 \%, 14.6 \%$ and $100 \%$. In weight, the relations between the three sizes of fish are tremendously disproportionate. The actual weights are as follows: the three-inch fish, five grams; the eight-inch fish, sixty-five grams; and the forty-inch fish, thirty-six pounds. This makes the percentages:

Five-inch $=.00031 \%$ or $\frac{1}{32} \frac{1}{6}$ of the large fish.

Eight-inch $=.4 \%$ or $\frac{1}{2} 50$ of the large fish.

All my inquiries in regard to tarpon breeding in Florida have been answered vaguely. There seems to be a general agreement that the young are hatched or live up the rivers or in ponds of fresh or brackish water. Not only would it be of great interest to have definite information concerning the breeding, eggs and young of tarpon, but it would clear up the matter of their near relationship to those fishes which pass through a larval or leptocephalus stage. ${ }^{\text {}}$

For the sake of helping in the identification of this most interesting phase, I have translated an article by Dr. van Kampen on the suspected larva of the East Indian tarpon. Together with the drawing of the larva itself, this will be found in Appendix $\mathrm{F}$ of the present volume.

${ }^{\mathrm{I}}$ See note at end of Appendix F. 


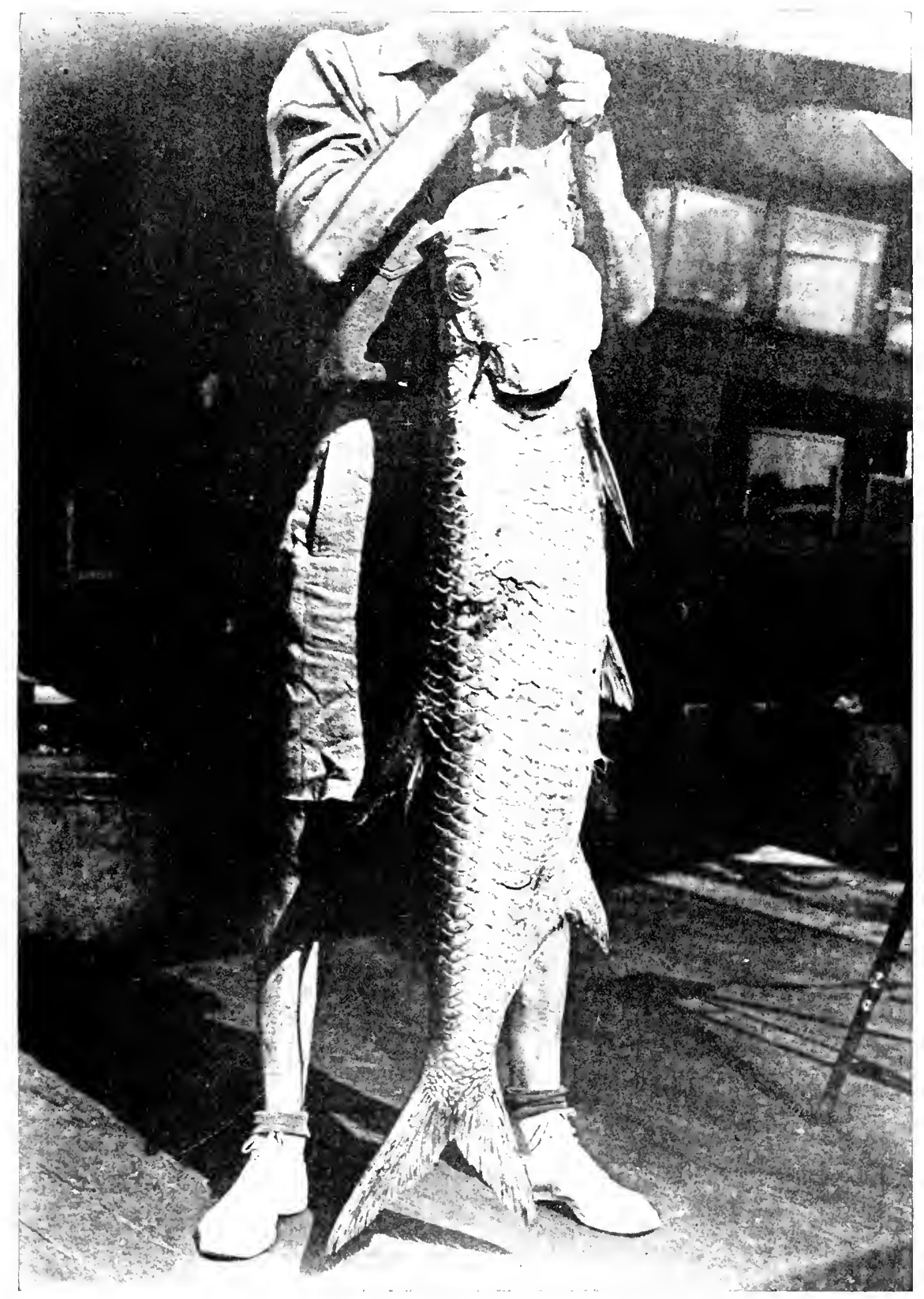

Forty-Pound Tarpon Caught by Haitian Fishermen 


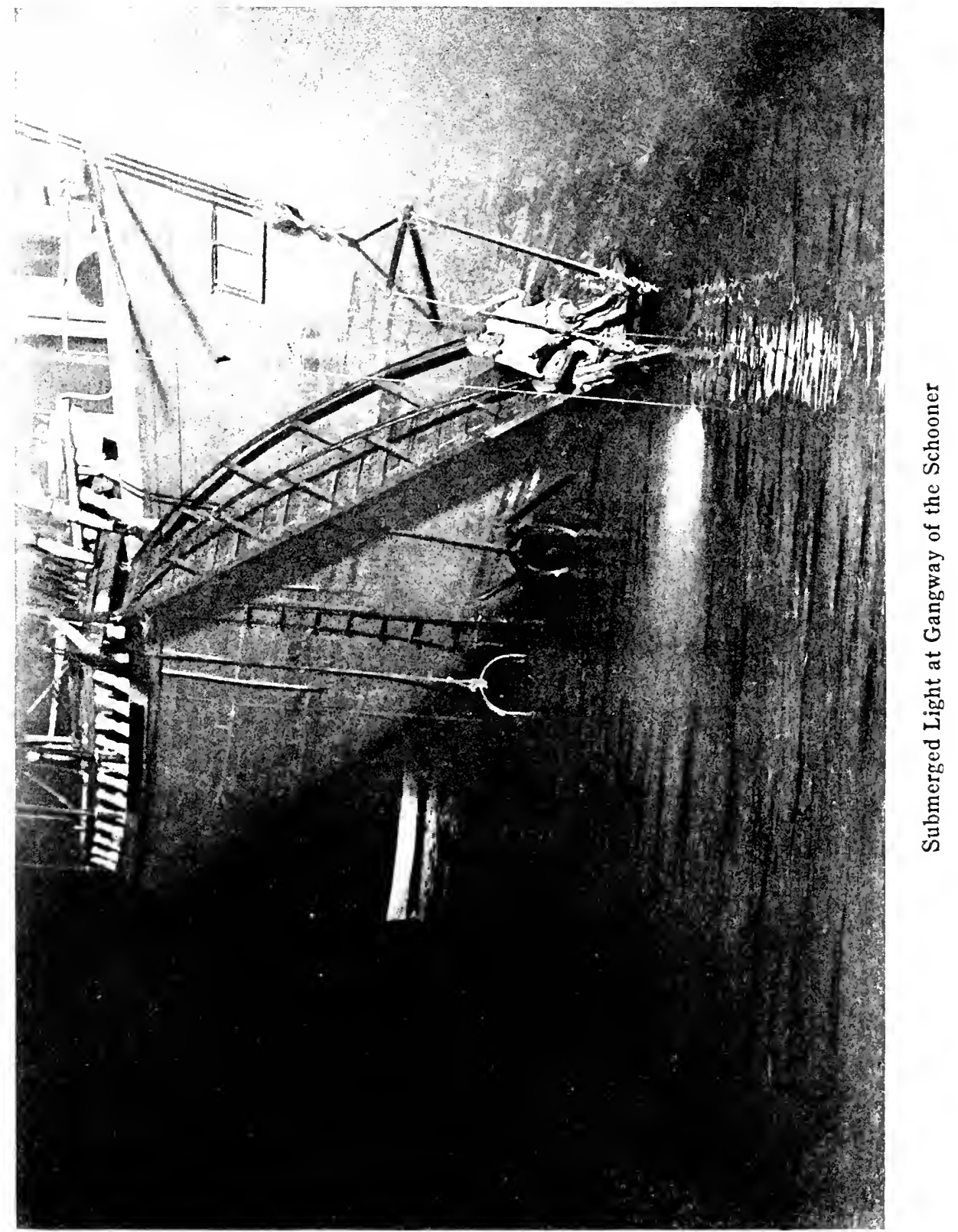




\section{CHAPTER VII}

WHEN NIGHT COMES TO WATER

In the late afternoon of the first day of May I leaned on the rail of my schooner and watched the dusk shift quietly into darkness. Before the last hint of afterglow faded I worked out an idle calculation with a pencil stub on the rough wood beneath my hand and found that one hundred and fifty thousand, eight hundred and thirty days ago Christopher Columbus had watched the Haitian sun go down over these same waters. On that day his men "caught many fish like those in Castile, dace, salmon, hake, doree, pampano, mullet, conger eels, shrimp and they saw sardines," -all perhaps the Nth great-grandparents of the fish who had come this very day to my hooks and seines.

The earth's horizon along whose farthest rim early rays were at this moment causing Bornean cocks to crow and sleepy Dyak savages to stir, rolled steadily upward from the edge of the glowing path of the great sun. This newest night, which had come to me as I stood alone on the deck of my schooner, was dark and moonless, half cloudy, half brilliant starlight. Before long I 


\section{BENEATH TROPIC SEAS}

noticed that the leg of the gang-way was brilliantly illuminated,- - the tide clashing into vision the latent phosphorescent cymbals of the great world of water life. Into the jet blackness of the water I threw a piece of coral,- - which, bomb-like, burst into a starry radiance of sparks, outside of which was a wide black area, then a broad bright ring of flame, which gradually grew larger and fainter. The lump of dead coral could be seen slowly sinking, clad in a renewed glory of its youth as it slipped down towards its old home.

The gorgeousness of the phosphorescence drew and held my attention and I began to experiment. I sent for a shotgun and fired into the water, and in so doing I started, on downward orbit, an incandescent comet whose head was a mass of glowing shot, which drew behind a sweeping train of trembling paleness. I then threw out a bit of bent wire and reproduced for an instant the glowing filaments within an electric bulb. Finally I dropped a pin, head-first, and from my post, fifteen feet above the surface, I distinctly saw the impact - a momentary flash-a single brilliant spark which died in the very moment of birth. So abundant and omnipresent were the hosts of tiny light-giving creatures, that the blow of a pin's head was sufficient to kindle an instant's blaze.

One of those supreme five minutes followed, which at rare intervals are granted me, and leave me gasping. My eye was drawn from the tiny 


\section{WHEN NIGHT COMES TO WATER}

star of a pin-prick, up to where a great tropical firefly was zooming steadily over the water, giving out a light as even and as brilliant as those borne by the deep-sea fish, a half-mile below the water of the open sea. With a last upward curve the flying beetle vanished and left my eyes, almost without a change of focus, fixed on the head of Scorpio, outlined against the velvety blackness of the sky. As I looked from Akrab to Antares and back again, a startling flash of lightning stabbed jaggedly across the stars from a rain cloud bearing down on us from the black mouth of the Valley of the Cul-de-Sac. And last of all, my eyes dropped to the thin, nicely evened line of the constellation of Port-au-Prince City along the distant horizon.

Never in my life have I seen such a succession of glorious illuminants crowded into an equal number of minutes,-the phosphorescence of life itself -the water for uncounted miles teeming with swarming hosts-all swimming dull and unseen, until some stimulus, bringing perhaps death to thousands, stirs them to momentary glory; the glowing body of the winged insect; the eternal patterns of the tropic stars; the majesty of the lightning; and the lights of the man-made cityman's handiwork seen at its best, illumined and at a distance.

Light-in-Darkness is a very wonderful theme and susceptible of endless elaboration. The fire and sun worshippers of olden times have more 


\section{BENEATH TROPIC SEAS}

followers today than we imagine. The house that lacks a fire-place is like a hypnotist without his shining jewel. The man who sits with his back to a camp-fire is not normal. Incendiaries are more abundant than revivalists. Jack-light hunting is the easy sport of cowards. A candle in the window is a loadstone to more than the signalled traitor. One electric Broadway sign is worth fifty daytime advertisements. Even the three wise men were assembled and directed on their way by a single point of light.

In the glare of high noon or at any time in full daylight, when I towed a net along the surface of Port-au-Prince Bay I would snare only a scattering of organisms. Fish appeared at the surface in numbers or leaped out mostly at times of stress or danger. The real abundance of life began a few fathoms down. On dark nights I would capture much more life in my tow-net, hundreds of small beings where by day there were tens. In the moonlight there was very slim picking, the cold rays seeming to press the swimmers down to where the deeper waters sieved out the sinister lunar power.

Desirous of using every available bit of time during the four months of our stay in this wonderland of waters, I had brought with me two mighty submarine lights, of one hundred and fifty and of two thousand candle-power. The larger was so powerful that it could not be burned in the air, but had to be sunk before we dared turn on the switch. 


\section{WHEN NIGHT COMES TO WATER}

For thirty-four nights, scattered through March and April, we kept vigil with one or the other of our lights, and watched and caught the creatures which came.

The light would be swung out gently from the deck and lowered about two feet beneath the surface. Then the great glow flashed out and with jars and nets I would walk down the gangway ramp, and drape myself close to the water on the small platform at the foot.

There was something-some uncanny attraction -which kept me squatting on the gang-way long after the ship had gone to bed, withstanding cramps and ignoring the green moons which danced before my eyes after staring for hours toward the blazing light. As far as I could make out, the fascination was the illimitable sporting chance of new and astounding visitors. My patch of watery light was connected aquatically with the ends of the earth and the deepest depths. From my hand dabbling in the water there was direct $\mathrm{H}_{2} \mathrm{O}$ communication with the Barrier Reef of Australia and the farthest open leads off northern Greenland,with the jungle-stained fluid thousands of miles up the Amazon, and with the crushing blackness of the Nares Deep, five miles straight down, and only three hundred miles from where I watched. This geographical poetic flight would be that and nothing more if my long, patient waits were not occasionally leavened with actual amazing and unbelievable people of the sea. 


\section{BENEATH TROPIC SEAS}

When I started down the side of the schooner there was nothing overside but a world of blackness. The only sound was the lazy tide gurgling now and then around the leg of the gangway. It took several minutes for my eyes to become accustomed to the sudden glare which tore through the dark like actual fire. I revolved the cable of the great searchlight and guyed it fast so it pointed outward. It dissolved not only the night but the water as well; as far as its rays penetrated the liquid was turned to air; the several jellyfish in sight were drifting balloons; an occasional fish did not swim but flew on its way; when my eye caught sight of the keels of the motor boats, they appeared absurd things-suspended in mid-air, and unaccountably heaving and settling.

On succeeding nights I realized the unusual value of the first few minutes of observation, for it was then that I saw things as they normally were on the surface, in the heart of the night's darkness. I was reminded of my greatest desire - that of being able in May or September suddenly to flood the sky with an unthinkably powerful searchlight and so to see the hosts upon hosts of migrating birdsmillions upon millions of them, as once I saw thousands roaring like a hail of golden bees past the torch of the Statue of Liberty. Perched on my platform I found it advisable to stare at my pocket search-light for a time, so that the instant the great flare was illumined my eyes would function. I had to look quickly, for almost at once the 


\section{WHEN NIGHT COMES TO WATER}

light would begin to exercise its transcendant power.

The little zone of radiance of which $I$ was the huddled hub became a nebula in space; the schooner was but an idea, I, merely an invisible onlooker. In the pale luminescent green ether surrounding the magic circle lay all the possibilities which ever cluster just beyond our sensory perceptions: I was one great eye.

The tide was flowing gently seaward. I could count ten large, parachute-like jellies-Aurelias they were-vibrating heedlessly here and there, all drifting slowly along on the current magic of the invisible moon. This aimlessness, this passive indirectness marked them as Plankton, $\pi \lambda \alpha v \varkappa \tau o ́ s$ or Wanderers, as the Greeks have it, in sharp distinction to Nekton-the fishes who have a will of their own, a directional intention which can take them across or against tides and currents.

A glance around showed that the color of the water near the light had changed; instead of pale transparent emerald it lad cooled to moonstore greyness. The heart of the nebula which had been without form and void was beginning to quicken into a nucleus. The visual magnetism had commenced its sorcery, and where only a drifting jelly or a casual fish roamed, was now the core of a veritable cosmos. What the sun and the moon could not achieve in surface life, my little light was doing. 


\section{BENEATH TROPIC SEAS}

More jellies came sailing down tide like an endless procession of pale moons. When they reached the light they almost vanished, so close was their body hue to that of the water. More and more gathered, and to my surprise these Wanderers, these merest Plankton, threw off their vegetative helplessness and suddenly began to assert themselves as Nekton. My light gave them character and will power so that when carried past they actually turned up-current and umbrellaed their way as close to the light as possible. Dozens of others came slowly, ghostily, up from the deeps and in less than a half hour the light was at the heart of a solid, heaving mass of life. It might have been some single, strange amorphous, breathing being of the sea, rolling about at the side of the schooner, even sending out an uncanny arm toward one of the bobbing boats. There was now no chance for any other kind of life about the light, so I scooped up a pailful of the Aurelia jellies and got thirty-one of good size. I took them up to the laboratory table and switched off the searchlight. My nucleus had grown too solid, too quickly.

An hour later I again went on watch. Only two Aurelias were in sight and these passed out to sea without stopping. About the light the hosts of tiny people of the sea began to color the water with such delicate subtlety that the increase in density might have been governed by an hour hand's movement,--from clarity to mistiness, from 


\section{WHEN NIGHT COMES TO WATER}

mistiness to translucence, finally to foggy opacity.

From now on, each evening and each night, there evolved a sequence of life about the light, impressive and dramatic to the highest degree, yet only dimly understandable by my dense mind and tremendous ignorance. If an observer could explain all that happened in the first hour about a searchlight such as this, he would possess the key to the populating of islands and continents, to the acute life and death struggles resulting, at one time, in an astonishing abundance of an apparently weak creature, and again in the sudden wiping out of some strong and sturdy form.

As in a hay infusion, there was definite sequence and irrevocable shift and change. After days and weeks of peering with my coarse human sight and insight I began to detect a hint of the wheels within wheels. Most of the forms first to appearcopepods and other minute crustacea-were attracted by the sheer impelling force of the light. They were like the lovers of open fires, and of electric signs, and of "Things that gleam and draw." But when the water became milky with these, then the secondary line of visitors appeared. They were camp-followers like the vultures and eagles which wing close upon the heels of flocks and herds. To them the charm of the light was less than the urge for food.

While every one of the great phyla of animal 


\section{BENEATH TROPIC SEAS}

life came, at one time or another, to my light, yet as I look back on the whole experience, there were three which dominated in numbers and conspicuousness,-jellies, worms and fish.

Whenever the slowly vibrating hosts of pale, blue-white Aurelias were about, more delicate jellies came lightward, little quadrangular oblong boxes trailing four medusa tentacles behind. The first time I saw them, a trio came surging toward me. The water was clear and very little life had collected. They moved with sudden vigorous jerks more fitting bone and muscle than flabby jelly and they bumped against the wire mesh of the guard of the searchlight. Suddenly a trick was performed. No fish had swum within sight and yet there were two fish before me. I swung my net at them and both might have dissolved into tle transparent liquid as far as results and my vision were concerned. I thought that the glare had overstrained my eyes and then I caught a momentary glimpse of a jellyfish in silhouette against the light,-I saw a small, curled-up object in the heart of its body and there stared out at me, dimly through the filmy tissues, an open silvery eye. I had resolved the trick and with one dip of a big glass jar I gently maelstromed the jelly into my possession. In the laboratory light I saw plainly the two fish within,-one pressed tightly against the wall of its padded compartment, the other turning slowly on its own axis.

How such a habit could ever have been inaugu- 


\section{WHEN NIGHT COMES TO WATER}

rated and established is inconceivable, yet it proved to be one of the commonest phenomena of the ensuing nights about my sunken light.

The jelly is the one known as Tamoya haplonema and has no common name, and we know nothing of its life-history. The fish is the well known Bumper or Chloroscombrus chrysurus. Night after night, the little balloons with their strange cargo would come and go. These jellies were made of well-knit stuff, four-sided, so that I called them the Quads, and they had four sets of six eyes-if that name is deserved by a series of convex lens which do little more than sort out light from darkness. Their creamy-white forms sailed along singly, or in twos and threes. On rare nights twenty would be in sight together, and about one in every four had fish for passengers. The size of these was very accurately adapted to their jelly transport,-small Quads had half-inchers, while big, four-inch jellies might carry a few two-inch fish, or as many as twelve of the smaller size. Twisting and wriggling about in the wake of the jellyfish were four, slender, pink tentacles, ready at a touch to shoot one's hand full of nettles. It was exciting to see the fish manœuvre for a few seconds before they dashed in to safety between the tentacles. It was like rumning into an open door before which was suspended a cluster of swaying, twisting live wires. I saw four of these fish which were killed by the nettle lariats, three of them already drawn well inside the mouth. 


\section{BENEATH TROPIC SEAS}

The fourth I saw caught, and after a terrific jerking it managed to snap free, but sank dying in the water.

Much has been written concerning the mutual advantages of such a relationship, but there seems little doubt to me that the jelly,-which is very close to the bottom of the evolutionary tree,knows nothing whatever of the affair. Between its stomach and egg pouches, within its umbrella, is a generous space open to the water, and this the fish uses as sanctuary from the host of dangers which ever threaten.

The Quad probably does not even know of the fishes' presence until one of them ineptly bumps against the hair-trigger of its nettle batteries, and affords it a hearty meal. The fish, on their side, have received, as part of their heritage, an instinctive knowledge of this balloon home. The first time an infant Bumper sees a Quad it is probably as natural for him to dodge the tentacles and dart within as it is for an incubator chick to peck at a bit of food. All this we can coldly analyze and apprehend, but when from a Quad measuring two by four inches, there pours forth no fewer than a dozen healthy little fish which must have been packed together like sardines in a tin, we must stop to give an incredulous, unscientific gasp of wonder.

On one of the early days of the expedition I was called to look at a huge Cyanea jelly drifting past. Armed with a pail I rowed after it in a boat, 


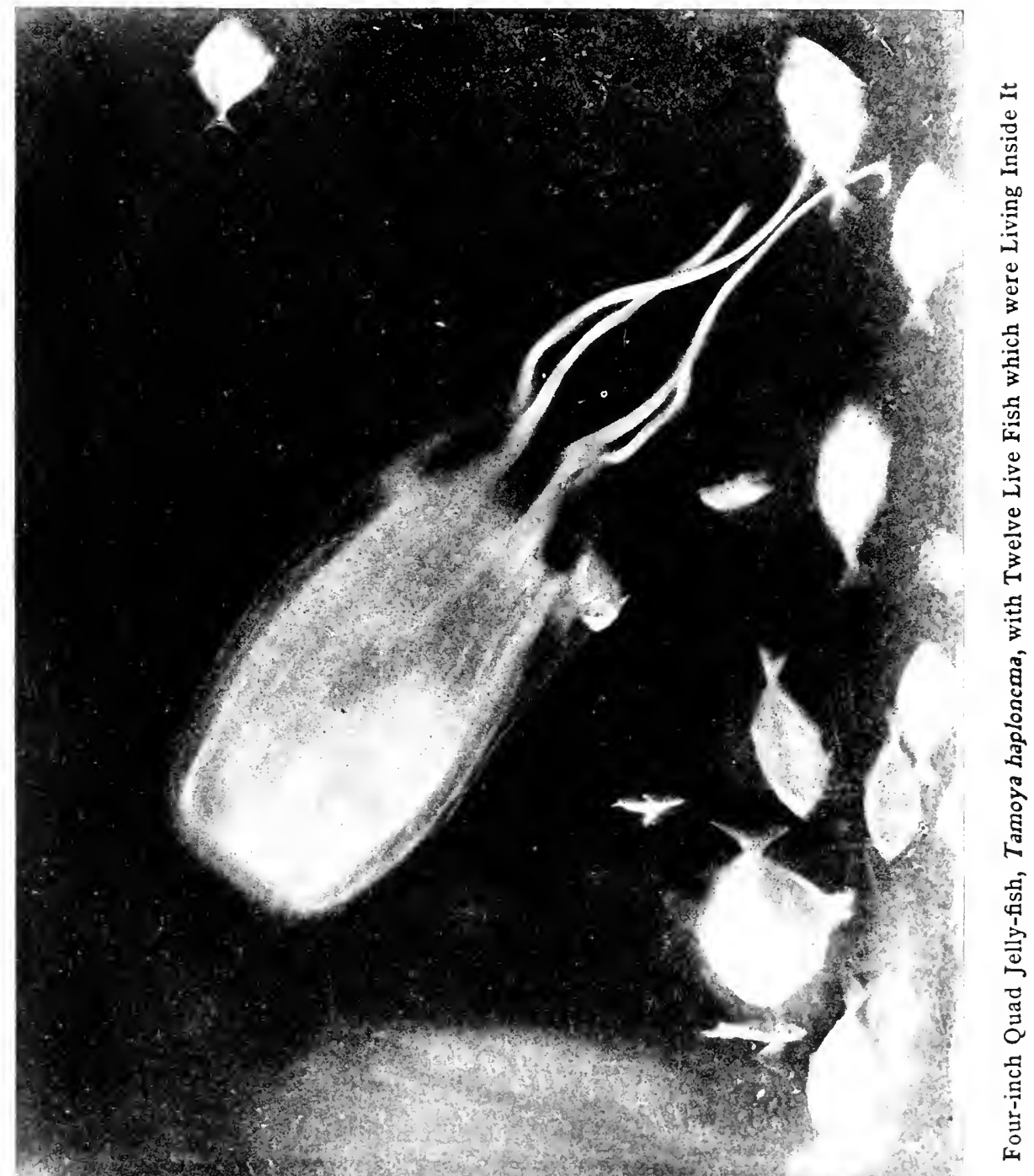




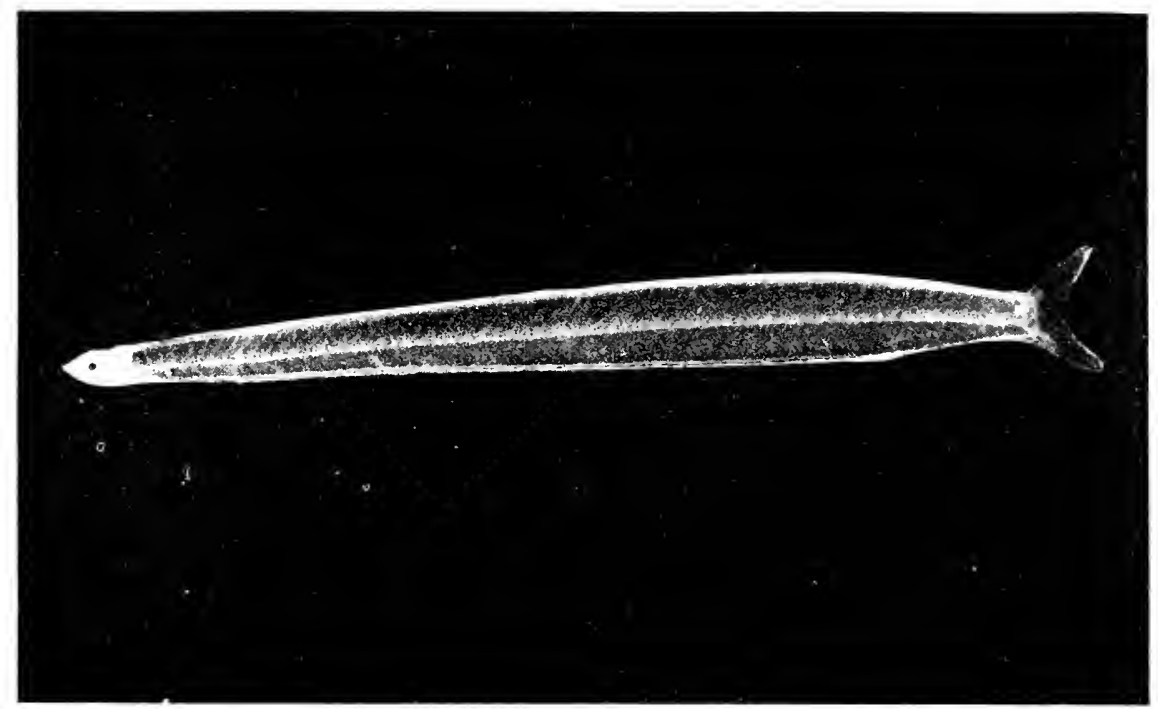

Leptocephalus Stage of Bone-fish, Albula vulpes

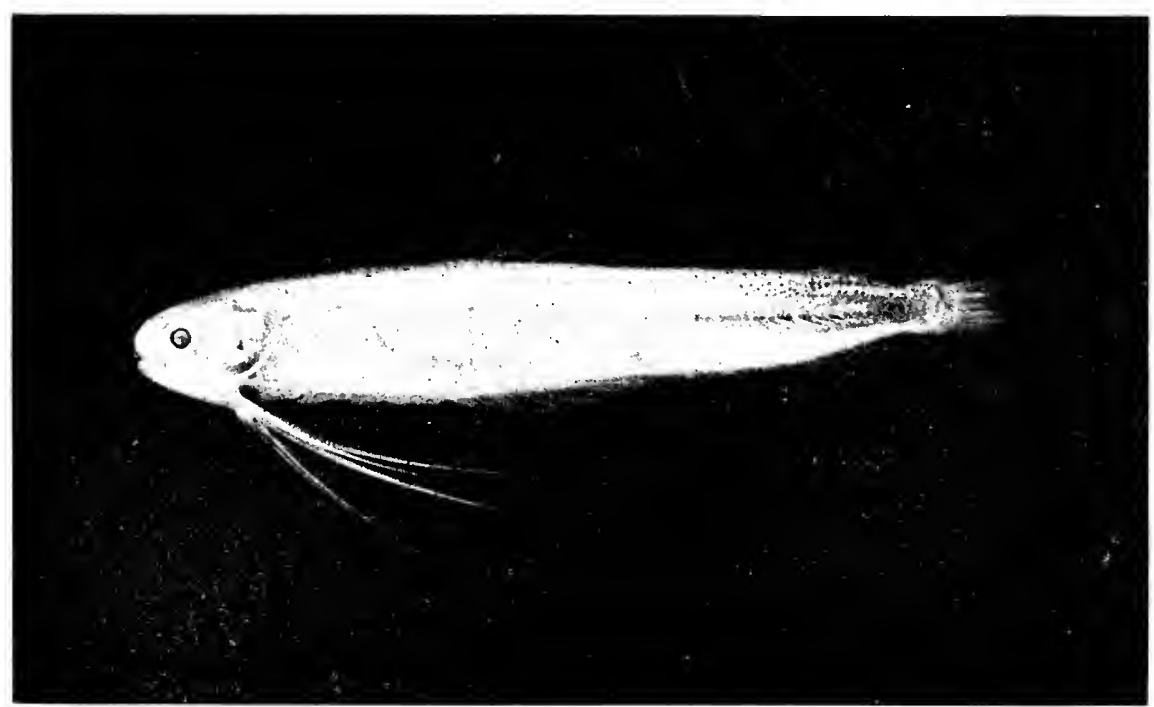

Bregmaceros, a Deep-sea Fish Caught at Submerged Light 


\section{WHEN NIGHT COMES TO WATER}

but was helpless to do more than ladle it about. It was several feet in diameter and quite too enormous to dip up more than a fraction at a time. I secured many small Bumpers and lost so many, that I estimated that there must have been several hundred at least.

Every night I caught sight of other jellyfish, waving their exquisite little transparent umbrellas, and there were ctenophores, shaped exactly like fourth of July paper balloons, with rows of shining cilia,-all appearing more solid and weighty in their shadows than in themselves.

Free-swimming sea-worms have never carried as deep an appeal for me as have other groups of animals. Many of them sting rather badly, and they do not enjoy being studied quietly in aquariums. Whatever interesting habits they may have are usually confined to their tunnels and burrows. But here at my light I had to pay attention to worms or shut off the light. They never failed to come; sometimes, as on the night of March thirtyfirst, in many thousands. Some were pink with white heads, others had a series of green scales down the sides; tiny threadlike chaps sent out an astonishingly powerful green phosphorescent light, and a grey worm with a black cap was one of the fastest swimming creatures I have ever seen-a veritable vermiform electron. Some moved so straight and steadily that they might have been propelled by a tiny turbine, but most travelled by frantic wiggling. The energy developed before my 


\section{BENEATH TROPIC SEAS}

eyes every night in transforming this host of worms into futile activity, would, if laid end to end-but complete it yourself. Besides, it was far from futile for the worms; it was the most important evening of their whole existence.

The most abundant form was pink, two to four inches in length, and bears the name of Nereis glandulata. Its numbers sometimes formed a maze of wriggling color about the light. I found that the paler pink individuals were females. Late on the twenty-seventh of April when other forms of life were scarce I picked out an unusally large female worm, and watched her. Up from the depths she came, and then worked in from the outer ring of darkness, forging steadily along, rowed by bunched oars, so small and swift that they seemed like a narrow hazy band down each side of the body. When she reached the light she shot past, then turned and returned, and moved in and out among the mass of fish and worms, small jellies and shrimps. Soon she began to describe large circles several feet across, swimming now fast, now slow, then came close to my seat on the gangway and threw a fit; at least no less vulgar, more accurate term came to mind at the moment. She stopped her headlong course and circled dizzily around and around in her own length.

At once the water of her little whirlpool became cloudy, then milky, then the worm swam a foot or two farther along, and, like a smoke-writing plane in the sky, established a new zone of pale- 


\section{WHEN NIGHT COMES TO WATER}

ness, and repeated this a third time. Meanwhile two worms of a lighter pink had shot in their erratic orbits across the first area. A shock of electricity could have been no more instantaneous, and if we estimated the egg-laying speed and energy of the female at Five, we must rate the gyrations and whirlings of the male dervish worms at Twenty. The cloud they scattered was less noticeable, but they went from one to the other of the spawn zones in a fine frenzy of fertilization, the female being still busy with a fourth area, but moving with diminished speed. She soon passed out of sight forever.

With empty mason jar I dipped up as much as possible of the first cloud, together with one of the males, and cached it safely beside me. The other male had just discovered the third ovarian cloud, and showed no slackening of his activity, when there came a swift finale. A small Quad jelly swam directly through the mist of worm eggs and the male in a blind rush collided fairly with a coiling tentacle. As abruptly as the presence of the eggs had affected him to frenzy of movement, so this casual touch brought complete paralysis. A third male who had just sensed the eggs swam in his very first circling against another tentacle, and off went the unconscious Quad dragging with infinite difficulty the heavy, dangling bodies of the pink worms. So much of a burden were they that for several minutes the jelly could make no headway and only jerked about in irregular circles. 


\section{BENEATH TROPIC SEAS}

At the end of the evening I went up to the laboratory and spent an hour or two watching what, to me, is one of the most dramatic things in the world-whether in the ovum of frog or worm. This is the slow, almost eclipse-like creeping across the face of the fertilized egg, of the crease marking the first division into two cells, then four, eight, sixteen and so on. And I was sorry I had spoken in a derogatory way of sea-worms, for they had taken me wholly outside myself for an hour and permitted me to witness life, birth and death, and a concentration of energy and enthusiasm which put to shame any of my half-hearted attempts at mere description.

We have a literary catch-phrase,-- "he was transfigured with emotion" - which may be applied most literally to these nereid worms of the sea. I sent a bottle of several to an eminent authority and he said at first it was quite impossible to identify them for they were in full breeding conditionknown as the heteronereis phase. To a non-annelidist, it sounded like being unable to recognize a peacock because it had a train, or a tanager when it assumed its scarlet body plumage. Eventually, with consummate skill, by dissecting out the jaws, the professor to whom I had applied was able to call it Nereis glandulata. It is an astonishing fact that when full-grown but still living in crevices or tubes on the sea-bottom, these worms have many generalized characters by which they can easily be recognized, but at the approach of the free- 


\section{WHEN NIGHT COMES TO WATER}

swimming, breeding season, structure after structure changes,- -appendages, skin covering, tentacles, eyes-everything except the concealed jaws.

I think the most constant feature of fish life about the light was youngsters of many species travelling singly. The surface of the water in the darkness of night and in the open bay, must offer many advantages and relatively few dangers to fish of the nursery age. From one-third of an inch up to two inches was the general size of the orphans and the total list of species would be a long one. They came slowly, but increased in numbers steadily throughout the duration of illumination. Many left after a brief circling, or a period of motionless balancing, staring head-on at the glare. Diminutive triggerfish treaded water with their bodies curled up, the tail fin pointing almost forward. Both shore and reef fish were represented, but half-beaks, puffers and triggers shared equally in abundance.

Within the first hour of observation I saw and captured several of the strange, transparent fish larvæ called Leptocephalids. I have told elsewhere ${ }^{\mathrm{r}}$ the remarkable history of the leptocephalus of the common eel, and in this volume ${ }^{2}$ of the probable larvæ of tarpons. Every night I caught and studied as many as possible, a total of several hundred. Many showed characters relating them to unknown species of eels, but others were un-

I The Areturus Adventure, pp. 22-25.

2 Appendix F. 


\section{BENEATH TROPIC SEAS}

questionably the young of ladyfish, Albula vulpes. There were none of the common eel, nor of the tarpons. I was interested in a six-spotted, rather rounded, opaque type of larvæ and found that it was an undeveloped lizardfish, Synodus foetens. Closely resembling this was a small species of anchovy which was usually seen singly, but on the night of March twenty-eighth appeared in several schools of five to eight thousand. Their whole actions and manner were totally unlike the isolated individuals. They moved with perfect synchronization, although raked again and again by marauding herring and voracious jacks. Often the school drew out into an oval, but usually the formation was an almost perfect sphere, moving swiftly forward until those in front touched the light, when the thousands would turn as one fish and roll away.

Close upon the arrival of the small fish each night, came the larger predaceous forms, schools of herrings which kept well down, flashing up now and then to seize a victim. By the fifth night I had to fight for my specimens. A school of eleven big-eyed jacks, Caranx latus, had established itself beneath the hull of the schooner, and as soon as the submerged light was turned on, they hunted along that side from stem to stern. The third night they had become so bold that they got fish long before I could reach them with the scoop net. I threw them a hook, caught one, and all the rest vanished. So this was my procedure every 


\section{WHEN NIGHT COMES TO WATER}

night; the moment they appeared I hooked one, and let him dash about madly, lifting him and dropping him back, until the fright was thoroughly imparted to the school, when all its fellows promptly disappeared. When the original eleven had dwindled, night by night, to six, I examined the food of one I caught and found thirty-three fish,fourteen anchovies, six lizardfish, six triggers, two puffers, five bumpers and one Bregmaceros. It was curious to observe that none of the predatory fish ever touched a worm or a true leptocephalus larva; these had only the tentacles of the jellyfish to fear.

The Bregmaceros was one of the rare visitors from the open or the deep sea, whose presence was wholly unexpected. I had taken it on the Arcturus at a depth of three-quarters of a mile, and yet here came a half dozen to the surface and scarcely a hundred yards from shore.

We have only begun to learn something of this strange world and can never foretell what the next moment will reveal. Three times I saw very small flounders come to the light, all of which I caught. The first was a young turbot, Syacium micrurum, absolutely transparent except for the tin-foil backing of the eyes and a few red-blood pigment cells in the gills. The others were fully pigmented when they first appeared. In the light one of them lost all color except for a greenish border. It undulated to the surface, curved down into a saucer or cup-shape with the circular fin rays above 


\section{BENEATH TROPIC SEAS}

the water, and floated until I captured it. It later repeated this in an aquarium, floating quietly for an hour. The fully expanded fins apparently made such intimate contact with the surface film that, like a vacuum cup, it remained suspended.

Equally unexpected visitors, which, like the flounders, seem wholly adapted for bottom living, were little sea-bats, Halieutichthys. They came up from the black depths with turquoise blue fins wide spread, and the only organ of propulsion the tail. With the slightest lateral movement they kept balanced in one spot or forged ahead, and thus remained at the surface with the least possible expenditure of energy.

The lesser people of the night - the true plankton - need a volume to themselves. Night after night I watched the minute swimming hosts collect about the light-month after month indeed, turning the water to a pale soup of vitality. I had given little thought to their real mission in life. As I have narrated, I had observed battle and sudden death, feeding and being fed upon, courtship and mating. And then I would put out the lights and lower the curtain upon human perception of all this maelstrom of activity. One day I made a deep record dive from the gangway, full ten fathoms down. It was an experience of tremendous interest, but as usual, in many of my efforts, one of the most startling things was as unexpected as it was obvious,- - the shaggy growths upon the hull of the schooner. The Captain I 


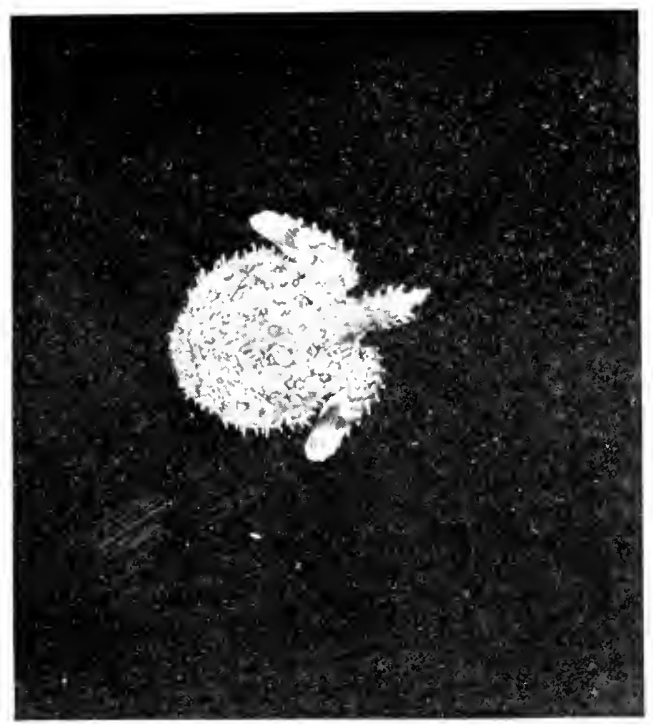

Young Batfish, Halicutichthys, taken at the Surface at Night

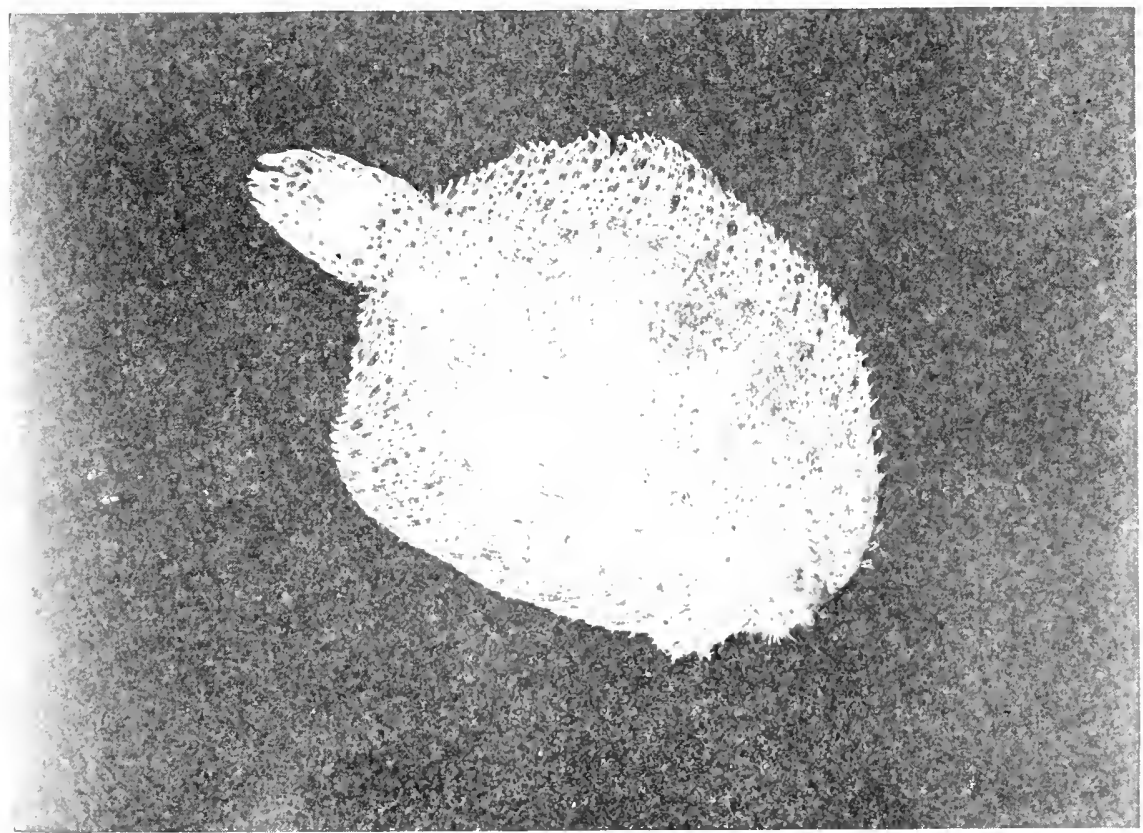

Young Flounder which Floats on the Surface at Night by Curving Its Body into a Cup-shape 


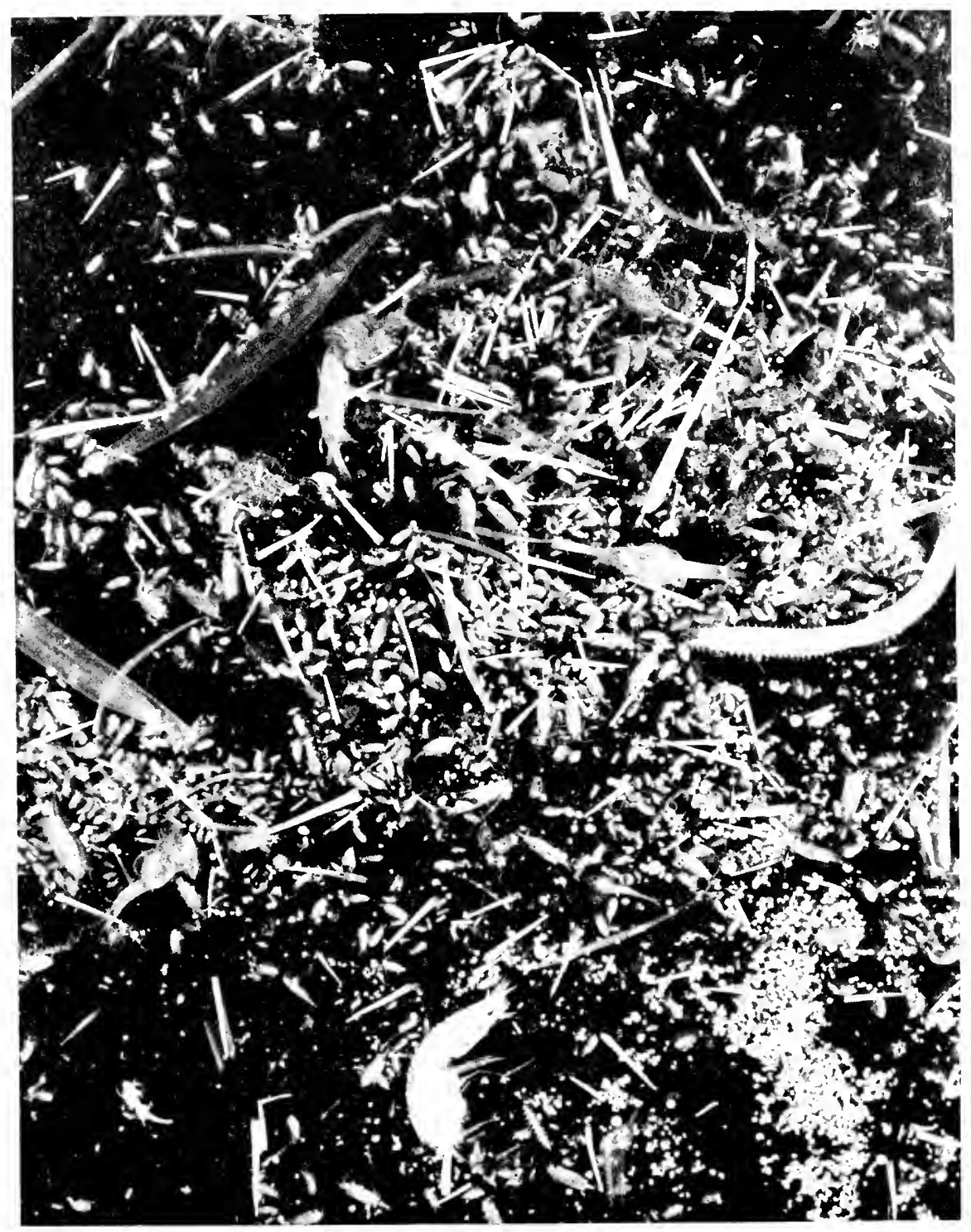


Photograph of Plankton, Collected at 8 P.M., April 30, 1927, at Submerged Ligbt In this picture are the following organisms:

FISH

$\begin{array}{lllllllll}\text { Larval Fish } & - & - & - & - & - & - & - & \text { Few } \\ \text { Fish Eggs } & - & - & - & - & - & - & - & \text { Few }\end{array}$

TUNICATES,-SEA-SQUIRTS, SALPA

Doliolum - $\quad-\quad-\quad-\quad-\quad-\quad-\quad-$ Few

Appendicularia - $\quad-\quad-\quad-\quad-$ Few

ECHINODERMS,-STAR-FISH, SEA-URCHINS

Larvæ, unidentified - $\quad$ - $\quad$ - $\quad$ - Few

MOLLUSKS, -SNAILS, CLAMS, SLUGS, SEA-HARES

Gastropod larvæ,-snails - - - - - Abundant

Pelecypod larvæ,-bivalves - - - - - Common

Crescís acicula,--Pteropod - - - - Common

CRUSTACEANS,-CRABS, LOBSTERS, SHRIMPS

COPEPODS

Eucalanus sp.

Corycaeus sp

Oithona brevirostris

Microsetella sp.

Small calanids
Copepod nauplii

CIRRIPEDIA,-BARN ACLES

Balanus nauplii - $\quad-\quad-\quad-\quad-\quad-\quad$ - Few

AMPHIPODS

Virbilia sp. - $\quad-\quad-\quad-\quad-\quad-\quad$ - One

ISOPODS

Bopyrid isopods (parasitic)

Few

Few

Common

- Few

- One

- Many

- Many

SCHIZOPODS

Heteromysis sp.

CUMACEANS

Cumacea sp.

MACRURANS

Lucifer-like macruran - - - - - - - One

Macruran larvæ

ANOMURA,-HER MIT-CRABS

Porcellana zoëa $\quad-\quad-\quad-\quad-\quad-\quad$ - Few

MISCELLANEOUS CRUSTACEA

Zoëans

ANNELIDA,-ANNELID WORMS

Syllidæ, (adult) - $\quad-\quad+\quad-\quad-\quad-\quad$ - One

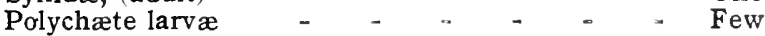

CHETOGNATHA,-ARROW-W,ORMS

Sagitta

CELENTERATA,-JELLY-FISH, ETC.

Hydromedusæ - $\quad$ - $\quad$ - - - - - - Two

Siphonophores - _ - + . - - One 


\section{WHEN NIGHT COMES TO WATER}

learned, knew all about it and considered it as unpleasant as we found it exciting.

This growth below the water line was much less dense on the port side beneath the gangway, than on the starboard. The Captain explained this as due to the fact that when lying at dock in New York City the ice jammed and scraped against the port side, removing much of the protecting copper paint. Two additional reasons, it seemed to me, were that the starboard was usually the lee side, and also got more sunlight.

At any rate, near the gangway there were several inches of sea-weed, and forests of hydroids, with here and there flattish, deep-red organisms, colonies of Botryllus-like ascidians, each individual delicately outlined with bluish-white.

On the other side of the schooner there was much red, hairy algæ and scattered through it, like partridges in tall grass, a diversity of creatures; jet black tunicates, Phallinia nigra, and others deeply tinged with rose, some of them three inches in height; occasional goose barnacles with deep red stems, white shells picked out with pale yellow and deep purple appendages. Here I found geranium-red tunicate colonies, sessile barnacles, and a host of winged, pecten-like bivalves. Walking about were numerous sponge crabs, mostly covered with hairy, red algæe, and clinging very tightly to whatever they walked upon.

Whenever we felt the need of a humorous touch in science, it sufficed to pry loose several of these 


\section{BENEATH TROPIC SEAS}

crabs and put them on view in an aquarium. Within a few seconds after regaining their balance they would cling together as closely as the proverbial burr or tar baby, and would begin to filch sea-weed from one another and landscape garden themselves. With eyes comically raised they would reach out with their claws, feel among the growths on the back of one of their fellows and pluck a bit of weed. The broken end was then placed in their mouth, probably to moisten it with a sticky secretion, and it was then solemnly planted on some shady portion of their anatomy where the crop was not doing so well. The comedy of it was only enhanced by the seriousness of the operation, - creatures with no means of defence endeavoring to efface themselves by transplanting sea-weed, sponges, sea-anemones, anything which they could move and which would take root on the hard, rough surface of their body.

A few weeks before, I had seen the swimming host of these self-same barnacles, tunicates and crabs scuttling about the submerged light, and now they had staked their all of life by settling down on this ready-made surface in mid-water. Here was a fascinating halfway house between the eggs and the larvæ and young in various freeswimming stages, and the centuries-old permanent coral reef itself, fathoms down, on the bottom of the bay.

I have material for a half dozen technical papers on the ecology of these relationships. In this 


\section{WHEN NIGHT COMES TO WATER}

chapter I have tried to present only a few highlights, which, after all, are almost wholly dimmed by the vast shadows of ignorance.

The last night of my stay I worked and watched on the gangway until I could drive my muscles and eyes no longer, then switched off the light and went to my tent. At midnight, in the blackest darkness, I turned on the light again for a single instant, and there were the multitudes still milling about,-searching, fleeing, fighting, mating. And I tried to imagine the centuries and millenniums that this had been going on before Haiti ever rose above the waters; and my mind went ahead to the ages when it would still be in full sway, eons after the last human being had completed his span of life, and I gave it all up. But I knew that as long as I could strive to take in the sweep and swing, the warp and woof of things, cosmically and universally, I need fear no touch of conceit for anything I might ever achieve. 


\section{CHAPTER VIII}

A SEASHORE ONE MLE UP

Like all American specialists in Haiti, the geologists have done their work well. The island shows signs of great volcanic activity, in full swing perhaps one hundred million years ago. Actual outbreaks of lava, although isolated and local, have been identified with Upper Cretaceous and Middle Eocene, say sixty millions of years before I write these words. At this same period a shallow sea covered part of the republic, and in the Late Eocene it was greater in extent, showing remains of one-celled animals and corals rather closely related to former Mediterranean species. Around thirty millions of years back, there was a shallow sea so extensive that it covered most of the island,-a Miocene sea with mighty coral reefs and snails of groups still living in these West Indian waters. This covered the Cul-de-Sac Valley and Port-auPrince and lasted until comparatively recent times, perhaps within a million years of 1928 .

Toward the end of the Miocene, only a score of million years ago, occurred the lifting, crumpling and folding of the Haitian Mountains which outline the chief modern features. It was during this 


\section{A SEASHORE ONE MILE UP}

period, or a little before, that the West Indies were much more extensive, and connected with either South or Central America, more probably the latter. During this time, strange prehistoric animals roamed freely over Haiti, leaving as proofs today their skeletons in the caves of St. Michel and other places.

The final elevation of Haitian mountains, begun twenty millenniums ago, is still going on with exceeding slowness, and the occurrence of frequent earthquakes show that Mother Earth is far from satisfied with the present subterranean conditions.

While my work was primarily under-sea and with fish, yet my atavistic ornithological impulses are as strong as ever, and I knew that nothing could curb my interest in Haiti and its fauna as a whole.

I was very anxious to visit the caves at St. Michel which had yielded fossil bones of birds and animals of great interest. So in mid-April I started with one of the aviator marines from the flying field in Port-au-Prince. Added to the joy of flying over this rugged island was the fact that I did not have to pilot, and so for once could give my whole attention to observation.

We climbed to a mile and then streaked straight across Cul-de-Sac to a pass in the mountains, over three successive ranges, and across the snaky Artibonite River to St. Nichel.

The landing field at St. Michel was such chiefly in name, and we fully expected to find that the natives had casually ploughed up some portion of 


\section{BENEATH TROPIC SEAS}

it. Instead, however, there were only horses grazing on it. We had to circle three times and almost clip the horses' ears before the crowd of onlooking Haitians got it into their heads that we would like to have the animals driven off. Finally we landed, bumpily, and were slowing easily when an oblique ditch materialized just ahead. My hands went like a flash to the duplicate controlsnot from any lack of confidence but sheer reflexbut my pilot did the only possible thing, turning straight up the shallow ditch, and we anchored safely with only the hint of a wing slide.

The manager of the plantation near the caves was waiting for me, and I made all arrangements to come up the following week with shovels and picks. This I never did, for when I returned to Port-au-Prince I found that Dr. Wetmore had arrived from Washington, and among other things had planned to visit and study the caves, and as no one in the world is better equipped for such work than he, I gladly gave up my intention, and concentrated on reef work.

We had to take off down wind and rose heavily but cleanly, slapping a branch as we soared, and went northeast toward Gonaives where I was ready to drop a mail pouch, but we were able to land.

While I had nothing to do but look down and scribble in my note book $I$ found it difficult to crystallize my thoughts. I have piloted so many times, with the constant responsibility of being 


\section{A SEASHORE ONE MULE UP}

ready for swift action, that $I$ found now the difficulty of transcribing scenes which in general had become too intimate and well-known for the perspective of description.

It was interesting to see, as we climbed, how soon man and his works dwindled and vanished. A village became a unicolor of brown husks, one of which had burst and scattered its seeds over a little area-this being the open market with several score of people and burros. Then the houses went. Horse-grinding sugar mills at this height became fairy rings, such as the wind-blown tips of grass-blades describe in snow or sand. Pigs could be seen long after human beings, for their bodies were low-hung, near the ground, and cast a solid shadow. With the long distance visibility of pigs still in mind it was interesting to notice that on the flat country near the shore, from two thousand feet, the most conspicuous and beautiful thing was the mirror-like sheen on an occasional mud-puddle. Soon my last thought of man went and I realized that I was looking down at Earth Herself, from space. No such feeling ever comes from the edge of the most lofty precipice; this is cosmic. I have flown hundreds of times and yet the feeling is always new.

Higher and higher we climbed, and now the great folded mountains dwindled, the lakes diminished to puddles, the shore to a colored string. Up to now, we had been concerned only with Haitithe island,--between other islands, in the sea and 


\section{BENEATH TROPIC SEAS}

from now on the thought shifts to maps, and the curved earth as a whole. Nothing matters above half a mile but physical geography. At this point I always-and please God I always shall-look quickly up to see if the sun or possible stars are not larger than they were before. No one who is bored with flying or diving has any business to return to dry land,- -he should be made into an angel or some other flying futurist at once, or dropped well underground into a deep grave to remain there forever.

My regret at having to begin the descent is always poignant. It is mitigated only by the unfolding of beauties perceived as if for the first time, after their synthesis by elevation. I mean no pun when I say that it is nothing short of an unearthly joy at having the colored string I have mentioned resolve itself into a three-fold spectrum, -the warm rich brown of the sun-baked soil, and the deepest of deep ultramarines, united by a narrow ribbon of breathless turquoise surf. Then the mountain wrinkles iron out into mighty cliffs and shadowful ravines, which might hold something of mystery if it were not Haiti; and the glistening slopes spread out into old, old beaches which have lost their turquoise, and whose stony corals and fishes and shells are washed now only by phantom breakers of cloud tossed at them on the waves of air. A glistening patch of white catches and holds the eye, and is soon surrounded by a medley of smudges which are not caused by 


\section{A SEASHORE ONE MILE UP}

wind and wave, or grown by sun and rain, and I know that the first hint of man is a great glistening mass of grave-stones, in the midst of the somber habitations.

The memory of one other flight must suffice. I wanted to examine some hidden, hanging valleys for possible new upland beaches, so at seven one glorious morning in mid-May, Major Geiger and I buckled on our parachutes and climbed aboard. Twice in my life I have made parachute jumpsonce for practice and once from necessity, and I should have disliked the third time to be among Haitian mountains. It is one thing to jump in open, or even flat-roofed country, but with ten thousand spires of pine trees on the upper slopes all sticking jaggedly upward, the prospect is not nice. From a height of even three miles one may drift safely downward for the first 15,820 feet, only to be crippled for life by falling the last 20 .

Major Geiger is said to be the best flyer in his branch of the service and I believe it. Also he prefers three instead of five thousand for steady going, and with me, skimming has always been a practice to the point of obsession. As we went over the swamps and open marshy flats just beyond the city I saw a dozen white egrets and a compact flock of some score of sandpipers. These latter would have been quite invisible had it not been for their massed, composite shadow moving beneath them, as they flew over the tan-colored mud flats. 


\section{BENEATH TROPIC SEAS}

At a half mile elevation we flattened out and took the first gap in the mountains at a gentle angle, much as a thoroughbred rises to a threebarred gate. Scattered wisps of cloud began tearing past when we were near enough to see the pines, and reminded me of the bits of floating cotton which I use in sponge plugging. We just brushed over the ridges, putting on extra speed as we took off, so to speak.

The whole trip was punctuated with air pockets and we bumped and careened gloriously at the will of the wind. Especially when we dived over one ridge into a breathlessly deep valley, side currents and unexpected eddies had great fun with us. The clouds were of all colors-the thin skeins cottony white, the more dense ones duskier and browner, and the high ones spectrum painted.

Shooting upward on the spout of air which geysered over the farther rim of one sharp saddle, I leaned far out and looked back and down, just in time to catch three disjointed scraps of rainbow in the auras of as many pillars of water pouring straight down into dark depths from the same knife edge.

At each ridge I enjoyed a sensation which has come probably to many of my passengers, but not to me when piloting. It was looking steadily at the silhouetted pines on the crest, ahead and somewhat higher than my eyes, to see them grown larger and larger, rushing headlong at us-seemingly with no alternative than to crash-and 


\section{A SEASHORE ONE MILE UP}

finally, as I picked out the particular branch into which I should be immediately catapulted, to have the whole sink slowly (never the sensation of our rising to clear them), and then marvellously to rush past just beneath. Never have I had this experience before.

Trees seen from above-not too high up-must be learned all over again, especially if the sun is not out. Cocoanut palms look like crinoids, sugarcane like moss. The higher one goes, the more important do shadows become in elucidating shapes and heights; Dunsany's shadow-land begins at one thousand feet. Ascent means optical devolution, whereby cows become pigs, and human beings chickens.

We swung down the winding valley of the Grande Riviére, with towns scattered here and there along the banks of the muddy creek, like casual knots of washed-up flotsam. I was watching a red-tailed hawk soaring high above the pines and equally far beneath me, when I followed a pointing finger, and there on a distant ridge, was the citadel of Christophe.

It was like nothing so much as a great ship, just appearing over the top of the mountainous crest, and a second glance recalled all the photographs I had ever seen of the temple at Lhasa.

Now and then Geiger passed me back a word or two of information on a bit of paper. Once I read, crumpled it, and threw it overboard and watched. It fell horizontally as far back as I 


\section{BENEATH TROPIC SEAS}

could see, and I did not lose it until it had become the tiniest of white motes against the green distance.

Cap Haitien came into sight suddenly and we made a great circle over the harbor, seeing the log wharf which, after an earthquake, sank evenly but wholly beneath the surface. There were no real reefs to be seen, and little shelter from the open sea. The shore appeared to be chiefly white sand. Halfway across the landing field, we discovered that the rest was damp or wet sand, and the Major turned almost in his tracks, a close enough shave to a turnover.

After five minutes, up we got and went for the citadel. On the way we passed over Sans Souci, and then followed the winding ribbon of road, twisting up from the plain to the great structure. First we circled slowly, at a distance, then, banking until we were all but vertical, we swept around again so close that it seemed as if I could reach out and snatch a bit of moss from the stones. I am glad that this has been my only sight, for I shall not think of it as a ruin. The view from the air, running as we were at eighty miles an hour, and yet circling, so that the building and ourselves maintained the same relative positions, revealed it as it must have been when weathered but in its prime. I did not register the fallen roofs or the rust on the cannon. The prow of the great Citadel was the unforgettable thing.

We were swinging homewards, through the heat 


\section{A SEASHORE ONE MILE UP}

of Haiti, when I sent forward a chit asking in what direction were Hayne Boyden's ruins. The Major's answer was to slip sideways off the face of a sheer mountain, shoot westward and skirt a steep range stretching far ahead to the very gulf itself. Over and along the entire ridge a dark phalanx of cloud was pouring, now down one side valley, now another. Dashing in twice, between wisps, we caught glimpses of the great manor house ruins, all that was left of the glory of the French colony of the 1770's.

Then we dashed into a pass, beneath a dense cloud whose drops struck our faces horizontally and as sharp as hail. Now followed an exciting fifteen minutes, twisting up a tortured valley, flattening against Mt. Terrible, with its sheer cliff of even-beached strata and gaping end-views of cloud-washed layers of shells and corals. Then, squeezing between a level, hanging valley and an oncoming cloud, we snatched a glimpse of great human-made walls, circular basins and long terraces which once were new and beautiful.

The Major's hand was pointing out the last and greatest of these ruins when the bottom dropped out of everything. We had already had several vacuums beneath us, and in France I had dropped more feet than I like to remember, with only time to gasp and go on. But here in this valley we struck a hole of what felt like naked ether and simply dropped-evenly but wholly. It felt like a mile. We grinned rather sickly at each other- 


\section{BENEATH TROPIC SEAS}

the plane took hold with its canvas feathers again and we went on as before. A last chit came, "Too damned cloudy." I nodded more heartily than I ever remember to have done at any news in my life, and we stuck the nose of D.H. 202 up toward a tiny shaft of blue struggling down between the mists. With only two side dips and a waggle at the summit she climbed steeply and reached the necessary level, and set her course over land and gulf straight for her hangar nest.

Having located some of the large inland lakes during my various flights, I paid visits to some of them-enough to collect the more abundant fish and to realize what an untouched field of research is offered by the ecology of these remarkable bodies of water. Étang de Miragôane is fifty-five miles west of Port-au-Prince and so completely surrounded by reeds and unfathomed mud that it is exceedingly difficult to reach open water. We had to be content with but a meagre showing of fish, but the marshes were a veritable open-air aviary. Glossy ibis got up and scaled over the reeds, herons - little blue, Louisiana, green and night, and both egrets-were scattered about. Jacanas were in family groups, stepping over the lily-pads, while curlew and yellow-legs waded and fed. Grebes of two species, noisy coots and clouds of tiny sandpipers made this an unusual sight in Haiti.

The great inland salt lakes of the Cul-de-Sac, especially Etang Saumatre would repay a six 


\section{A SEASHORE ONE MILE UP}

month's study. It is a dying lake and has retreated half a mile in eight years.

We got in an old leaky boat and were pushed by three husky boys for several miles through the shallow water. Here and there in the distance the eyes and snouts of crocodiles appeared. These reptiles would swim toward us for a time, then turn and dive. A scarlet cloud, far off on the shore, became more compact as we drew near, and soon rose and spread out into a wonderful undulating line-and one and twenty flamingos completely circled our boat, all gorgeously scarlet save the last three grey youngsters which had some difficulty in keeping up with the rest.

The water is brackish and it is surprising, so far from the sea, to find gobies and small gars. Here and there along shore, fresh-water springs well up and flow between pebbles into the lake, and within the sphere of influence of this fresh water thousands upon thousands of small minnows live. How they got there or how they can find sufficient food in such small, fan-shaped areas I cannot imagine. Yet they were thriving, as completely set off from the rest of the lake as though the barrier had been a mountain and not an invisible salt solution.

On the way across the lake I noticed holes scattered about in the bottom mud and when I inquired of our youthful turbines, one of the boys sank down on his knees, reached deep in with both hands and presently came to the surface holding 


\section{BENEATH TROPIC SEAS}

a good-sized wriggling fish. This novel method of fishing yielded us half a dozen of an interesting member of the genus Cichlasoma. These belong to the family Cichlide which are found only in the fresh waters of the tropics. They seem to be excellent parents and one species which I studied at Kartabo in British Guiana was always found in pairs. Whenever danger threatened, the brood of fifty to a hundred young would dash into the mouths of the parents, where they would be kept until it was safe for them to swim or be spat out. Near this Haitian lake I saw, in a stream, one of these burrowing Cichlasoma's with a dense cloud of young about it. As I started to wade in its direction, the young vanished with amazing celerity, so it may be that here too the same sanctuary is in use.

After learning what I could of the fish in the lowland lakes I hoped to find something exciting in the streams of the uplands. On the eighth of March, led by the indomitable wife of General Russell, we motored to Pétionville, and there mounted horses for a long ride up into the mountains. Our steeds were small in stature, but great in emotion-stallions all-who neighed shrilly all the way, pranced with excitement at the sight of every cow and goat along the trail, and reared on their hind legs and pawed and bit one another at every opportunity.

The first few miles we rode beneath great trees, draped with grey moss, among the foliage of which 


\section{A SEASHORE ONE MILE UP}

woodpeckers hammered and todies creaked while two big hawks hung aloft and watched our slow progress. The valley of the Cul-de-Sac stretched out more and more and at last the great salt lakes came into view. The road wound and wound about, always zigzagging, always up.

Martins appeared, a hawk rushed past, screaming as it went. The road tipped over the rim of the world and the whole hemisphere and zone shifted and I was riding the trail to Mussoorietoward the gateway of the Himalayas. In all my flying over Haiti I got no such sudden shift-such complete translation from the tropics behind, of a West Indian island, to the absolute threshold of the Hills themselves! As we went on and up, there opened out an inconceivably steep canyon with a dry torrent bed at the bottom; huge boulders, moss-covered, jutted out from the sides, bignonias bloomed on the trail, and instead of the hot, moist air of Port-au-Prince there came to my nostrils a breath from the snows. I sat straight up in my saddle, breathed deep and thought of Kim's red Lama who strode out across the country when he sniffed the air of the Hills.

With the last glimpse of the gulf and the Cul-deSac, all hint of the tropics vanished, and we were in a land of pines. Swallows swooped across the trail and criss-crossed the sky; the banks on the mountain side of the trail were padded with giant eagle brakes, and tree-ferns came into view. I stopped at the edge of a sheer precipice, and the 


\section{BENEATH TROPIC SEAS}

wind, cool and bracing, ran up the valley beneath me, laden with the scent of pines which were growing still higher and as yet invisible. Junonia butterflies fluttered under my horse's hoofs, no different, as far as I could see, from those of Sandukphu, warming themselves on the rocks in full view of Everest. We pushed past tall blackberries and flaming cardinal flowers.

Our objective, the gendarmerie at Furcy, was on an outjutting ledge, the land dropping steeply away in every direction except the saddle of the trail. As I rested on the verandah grackles clacked in the distance and great doves cooed from the pines.

I walked far down to a stream in the bottom valley, a tiny stream meandering among an outcropping of volcanic rocks, which formed jolly swimming holes and tinkling waterfalls. A northern water-thrush dipped here and there. Everywhere were the same eagle ferns which I had seen in China, India, in the woods of New Jersey and in the Malay States. As regards fish my trip was a complete failure, for not a minnow swam here, but I forgot this in the next second in the strange familiarity of my surroundings. Beetles, striders and water boatmen there were in abundance and many small aquatic snails.

Before dimner time we were glad to have logs roaring in the fireplace, and when we walked in the cold wind of early evening we needed all the sweaters and coats which, with such reluctance, we had strapped to our saddles. 


\section{A SEASHORE ONE MILE UP}

We watched the sun vanish-a red ball in grey mist, with the jagged ranges all around, valley after valley closing its doors to the day and drawing within its cloak of shadows.

This very day I had stood in my stirrups and pried loose the shells of huge oysters from their bed in the cliff overhead, and curious bivalved mollusks and the twisted forms of worms and branches of coral which had flourished when Haiti and the world was young. Once then, all this region had been below the level of the sea-first to be thrown up by volcanic outbursts and then built upon and added to, throughout the ages, by the patient labor of corals. Of the fish of these times we shall never know more than the impressions of their bones, but in the failing light of this dying day my imagination worked swiftly and wrought a realistic vision of those early years.

I looked away toward a distant ridge beyond which lay MIt. Terrible and its tangle of slopes and ridges among which $I$ had flown. Even in the brief glimpse allowed me I had caught sight of dark-mouthed caverns and deep-cut crevices. And I thought of the time, millenniums ago when any evening among these same mountains would echo the call of the giant owls whose bones now lie in the cavern débris. And I visualized these mighty eagle-like owls pouncing upon the equally great rodents who browsed upon the prehistoric foliage; and then came to my mind's eye the strange, unwieldy ground sloths which we know lived here. 


\section{BENEATH TROPIC SEAS}

What would I not give in exchange for five minutes of coexistence with them!

As the sun went down on this very newest of the world's days, one of the valleys could not join its fellows in their darkening twilight-a valley whose slopes some dark-minded native had put to the torch. Some negro wished to burn the brush on his miserable garden ledge so that he could more easily plant his next crop. The fire did his bidding, and then he turned and closed his door and in his air-tight hut of thatch and clay snored through the night. But the fire knew no sleep, and looking up, saw with joy new realms above, and on and on it leaped, and when the sun sank it had spread so that it could pretend to be a constellation-the first of the night stars. In the darkness across two valleys I could see every limb outlined as the flames licked up the pitch trunks and roared through the resinous needles. Yesterday the slope had been densely covered with splendid trees. They had stood patiently for a century or longer, drawing to themselves largesse of earth and sun and rain, and fashioning this into splendor of trunk and root and needle. Now, at the scratch of a match, a goodly fraction of the horizon was wickedly wrecked; the morning would show only smoking ruins.

At midnight $I$ rose and walked for a time in the moonlight. My path lay a mile above the tropical sea-all invisible to me but stretching away from Haiti in every direction. As soon as 


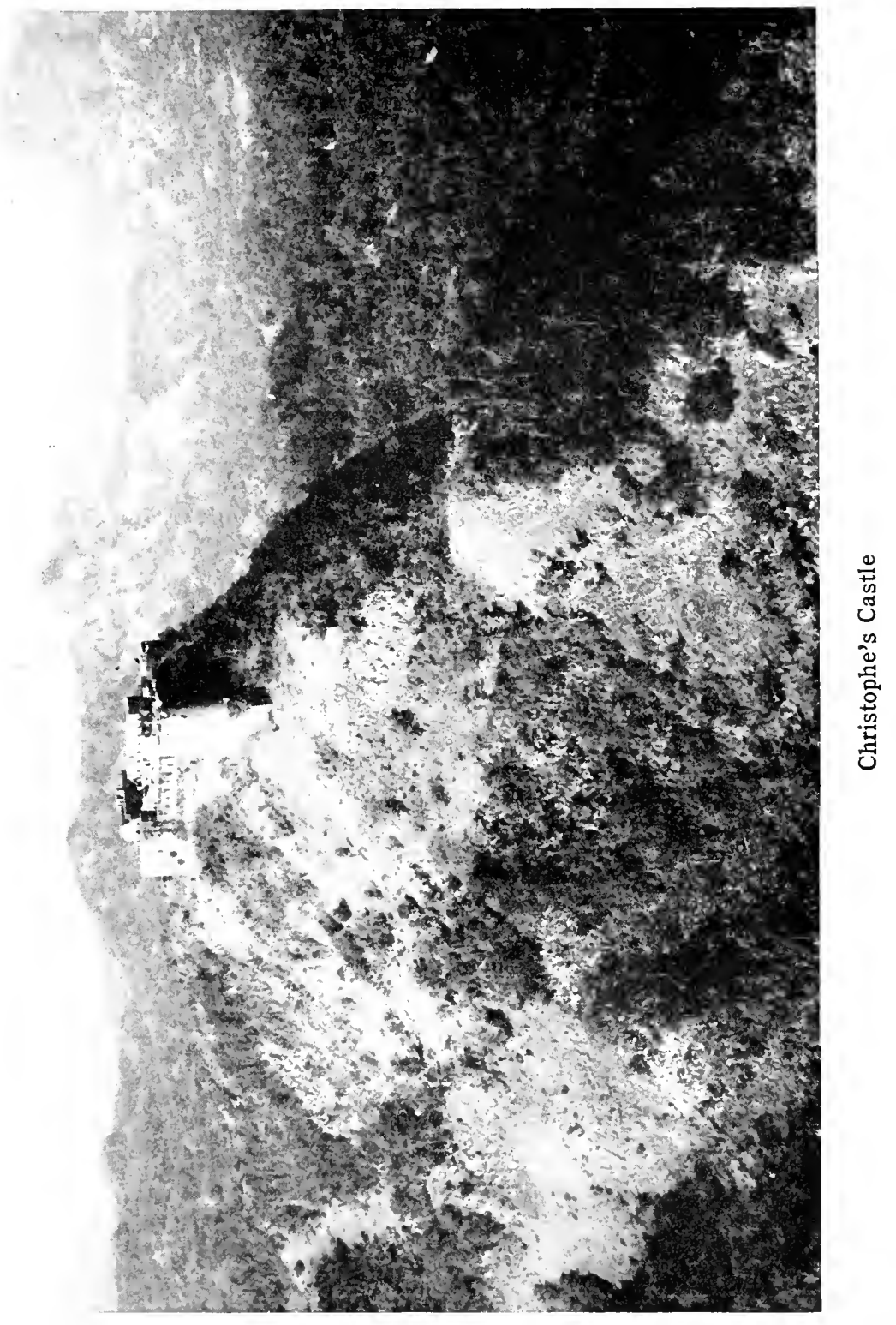




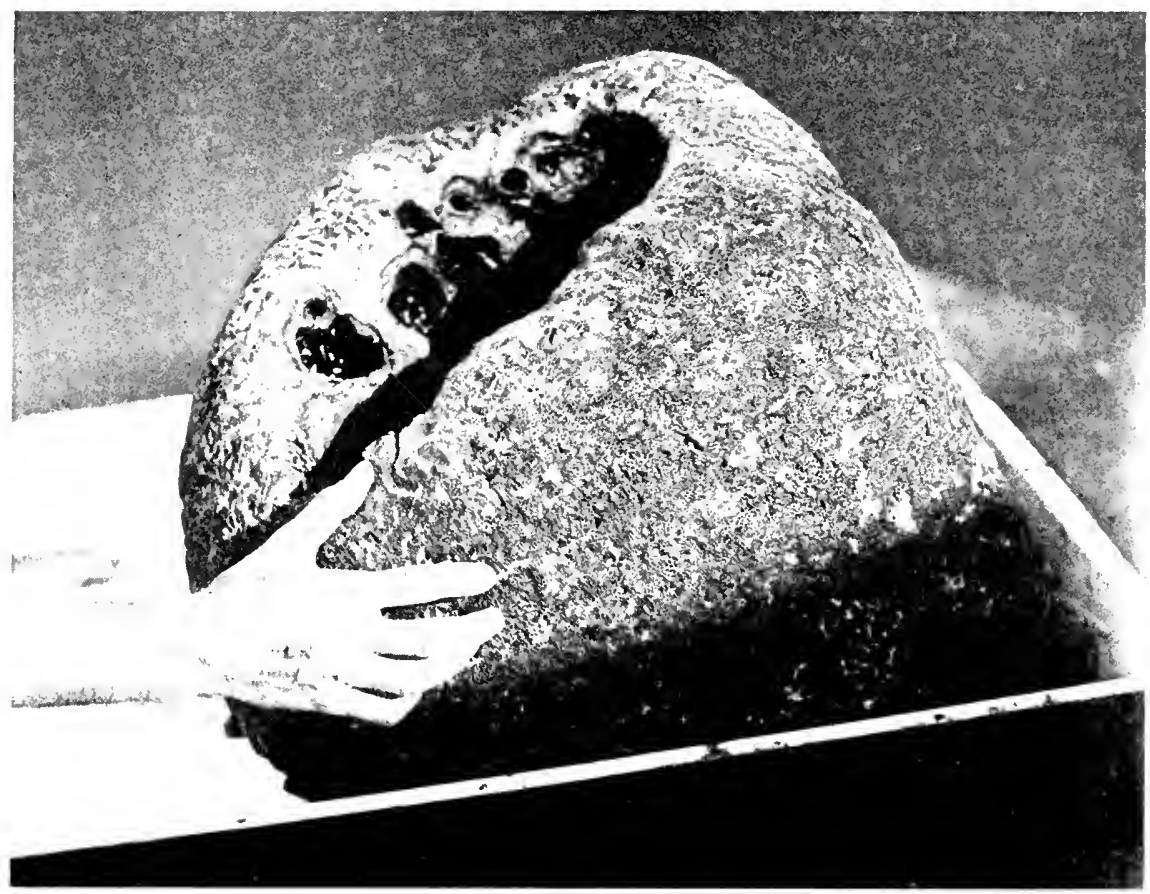

Giant Sponge from Lamentin Reef

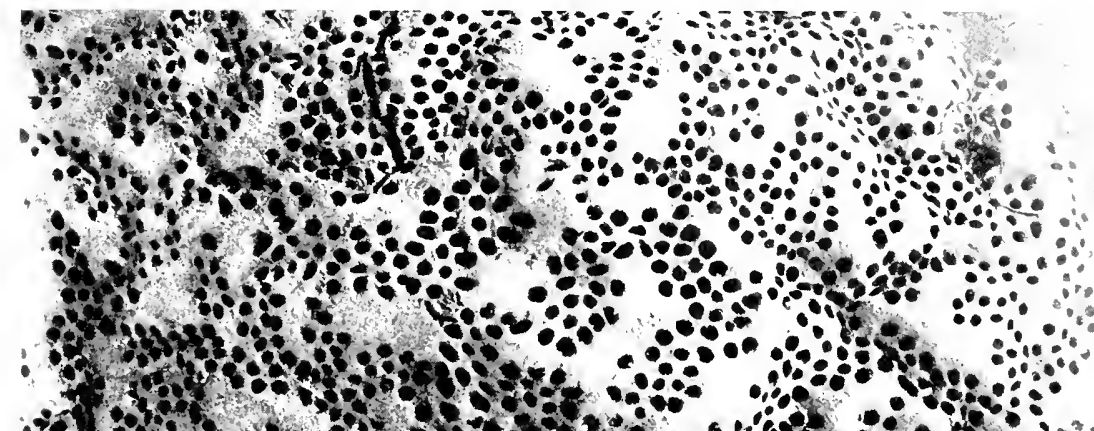

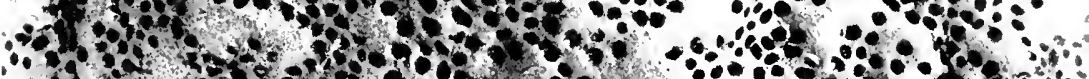

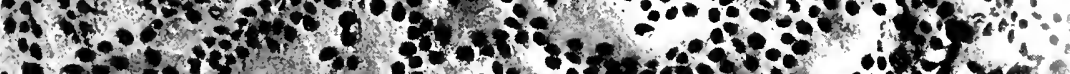

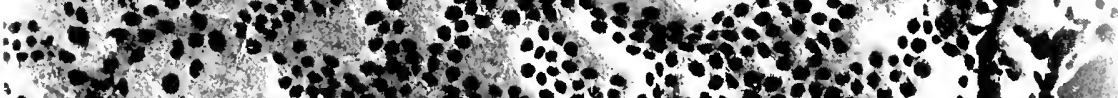
ind

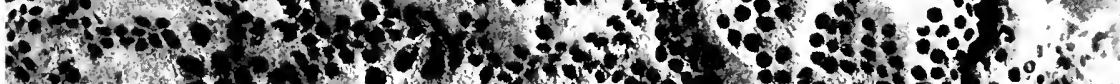

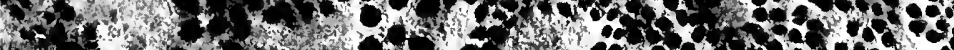

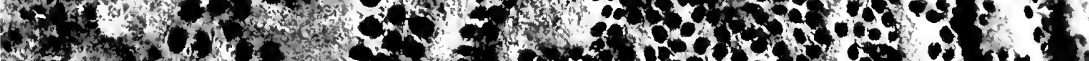

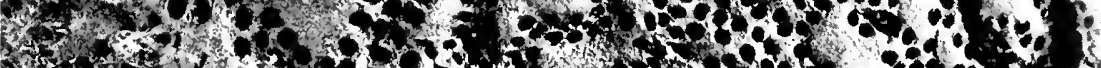

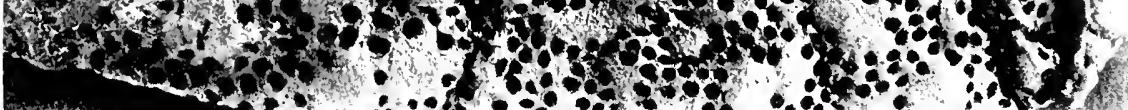

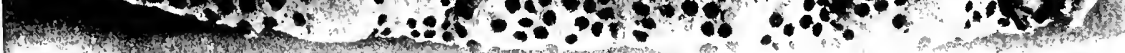




\section{A SEASHORE ONE MILE UP}

I dropped below the ridge the chill air was quiet, while overhead the wind soughed mournfully through the needles about the gendarmerie, with the self-same sound as it used about the dâks in Sikhim close to the snow line. A man passed quickly with his head tied up-as the Tibetans, not the Haitians, do.

I went on and on, unconsciously listening for the call of a tragopan, or the snarl of a snow leopard. But nothing came but the rasping snores from this hut, then, before I had quite got beyond ear range, the groans of a mother in childbirth, then more snoring from another isolated hut, and I returned, disillusioned, and the soughing took on an ironical strain. The gods of memory were laughing at me and, as Dunsany says, the laughter of the gods is always ironical laughter. 


\section{CHAPTER IX}

SPONGES

Aristotle took sponge baths. He also knew that sponges were animals, and when, in the Iliad, Homer described a sponge as "full of holes," he expressed about all the knowledge which mankind has possessed until comparatively recent times.

When a human being, especially a product of intensive civilization, steps out of his life rut, the narrowness of his knowledge becomes terribly apparent: what seemed ultra-sophistication turns into provincialism, and instead of a man-of-theworld we have a puzzled child often striving to conceal its ignorance in facetiousness. When the glory of coral reef sponges first comes to the eye of such a person, he exclaims, "Sponges! Bathroom sponges!" He visualizes a dish of cabbage when a royal palm stretches its majestic bole up and up into the sky, he misses the beauty of castor-oil foliage and ignores the deep wine-hued grace of banana blossoms. If we should go into a great gallery, slit up its priceless canvases, cleanse them of paint and put them to some drab, prosaic use, vandalism would be a quite inadequate term. Yet (permitting ourselves to wallow in sentimentality 


\section{SPONGES}

for a moment) this is very much like what we do in the sponge world. Having admitted and forgotten it, let us now seek to acquire merit by making our bath sponge quicken our mind with the splendors of the living beings themselves.

Sponges hold no mean position in the kingdom of animals, for they comprise a group equal to that which includes all back-boned creatures from sharks to ourselves, and they have the honor of being the lowest living animals whose bodies consist of more than one cell. I am always fascinated by the astonishing skill of a man who plays six or eight instruments at once; and under the microscope an amøba fills me with the same admiration, when I see it move and eat, choose and reject, live, reproduce and die. But, as in the case of the solitary human orchestra, the single-celled animal soon palls, and I turn to other, more complex organisms.

Let us enter the realm of sponges. With helmet, hose and pump in order, I slip off the port gangway. With a last Blop! of air I submerge on my slim rope, and slide gently down past the schooner's hull. The waves are high and the water is filled with powdered lime, and down and down I go through the heart of a liquid column of chalk-my uttermost horizon less than five feet away. A smudge at last appears beneath and, in our present anchorage, at seven fathoms my feet touch bottom. I suddenly realize that on the way down I have revolved slowly and that somewhere above me the 


\section{BENEATH TROPIC SEAS}

hose has become entangled with the rope, and my consequent hurried respiration does not help the air supply. I lean slightly over and the water in my helmet rises and splashes in my face. My muscles, for a moment of panic, start me nervously up the rope, then sanity resumes charge and I turn back to secure some evidence of my having reached bottom. I squat down, breathing as quietly as possible, and through the lime-filled murk I make out a scraggy sponge crag. I loosen it with my foot, and then, reaching down, tear it off and tuck it inside my belt, for I must have both hands free to climb, and to untwist the hose. Before I dehelm I hold up the sponge for safe keeping and as soon as I reach the deck, submerge it in an aquarium.

The afternoon sun was pouring into my deck laboratory window when I placed a tiny bit of the black sponge under my microscope, and lost myself. There, stretching before me, lay slope after slope of brown downs, occasionally rising into a small, sharp hillock, and everywhere pitted with holes. If it had been ploughed and gashed, it would have been the terrible volcanic wastes of Albermarle, but here instead, were mountain slopes collandered with innumerable gopher holes. Within my field of view were two oblong caves, etched deeply into the hills, and from these the perforated expanses swept downward into the awful gulfs of out-of-focusness. Having surveyed my pennywide landscape, my eye settled to details, and 


\section{SPONGES}

suddenly I rerealized what I had known in the first place but had forgotten in the vividness of the mountain vision-that the whole landscape was alive, animal, sponge. One of the cave mouths abruptly drew its lips together and blew forth a current of water, this being made visible by the smoke-like motes floating in it. I should not have been surprised to see the pensive, lonely eyes of the last "reluctant dragon" appear, looking wistfully about for his small boy friend. Scientifically, the sight of the cave mouth pursing its lips is an observation of considerable interest, for muscles of any kind in the integument of sponges are practically unknown.

I scattered a pinch of carmine dust upon the water and all the inner activities of my hillside were revealed-each little pothole frantically sucking in its mead of food-laden water, while now and then the accumulated flood was washed out of the communal channel.

In a book of ancient yarns, written over six centuries ago, somewhere about 1300 , a Spaniard offers a prescription of toasted sponge for use in troubles of the throat. And again and again through the middle ages chirurgeons prescribed the bath sponge as a cure for croup. In one of the most modern and authoritative medical volumes, we read:

"Before the discovery of iodine, roasted or burnt sponge was generally used in the treatment of goiter and also croup, with excellent results in 


\section{BENEATH TROPIC SEAS}

appropriate cases. It is now altogether superceded by preparations of iodine."

So when in diving helmet we walk on reefs, and pluck sponges of all colors and sizes, and come to the surface with our fingers black and brown with iodine, we remember the old specific. Sea-weeds which are counted rich in iodine contain only about one and a half per cent, while some of our sponges possess as much as fourteen per cent, or almost oneseventh of their entire being. The big sage-green, chimney sponges begin to turn black and to darken the water as soon as they are put in an aquarium.

As we have seen, an active, excited sponge has, in the matter of movement, little advantage over a bit of moss, and yet an infant sponge, swirled out upon the current of the parent cave-mouth may found a new colony half a thousand miles away.

The eggs begin their development deep within the jelly-like tissues of the parent sponge, and one day, in company with unnumbered hosts of its fellow brood, an embryo works itself free, whirls around and around, and shoots out of the exhalent pore into the world of ocean. It looks like an infant balloon, the upper half of large, smooth cells, while those of the lower half each bear a long tail or flagellum which beats frantically upon the water. There is no unison or rhythm,- - each lash whips out at its own sweet will, but they do manage to beat more strongly in a backward direction, and thus the balloon forges ahead. The light 


\section{SPONGES}

attracts it, so it drifts along near the surface, its own power of propulsion being nothing in comparison with the force of winds and currents. In the course of time it acquires a distaste for the light, and thereupon heads downward, and sooner or later bumps against the bottom. Here it sticks,-the chance of striking a favorable spot for growth being probably about one in a million. The larger cells increase rapidly and form an outer covering, the locomotor cells disappear within, and thereafter are of use in making their own private currents, whose eddies bear oxygen and particles of food to what is now a sponge.

No human being would hesitate if compelled to choose between being a seal and a sea-weed. Yet there are some advantages in being rooted to one spot. The seal has to go after its meals and flee from its enemies, while a sea-weed and a sponge simply sit and let the currents bring food to them.

Now and then a certain type of lucky spongelet alights on the back of a hermit crab's shell, and like a burr on a dog's coat, gets a free ride. In the case of the sponge this is for life, for it speedily dissolves the shell and forms an elastic and evergrowing coat for the fortunate crab. From now on, sponge and crab live amicably together.

The relation of a sponge to itself is a most intricate problem. It is so plant-like that if one be chopped up into small pieces, each cutting, in the course of seven or eight years, will form a bath sponge of commercial size. My hundred-and- 


\section{BENEATH TROPIC SEAS}

fifty-pound capture was a sponge, but each of the many groups of lashing-cell canals had its own private exit canal, and might perfectly well be considered a separate organism. In some ways the schism between these groups is greater than between some organisms wholly separated, such as individual army and leaf-cutting ants. Some day, very wonderful discoveries will be made of the binding power of relationships too intangible to be perceived by either sight or touch. Meantime, not further to confuse my sanity, I propose to call my giant of the reef, a single sponge.

While no sponge has a skeleton comparable with our bones or even with a grasshopper's armor, yet the whole body mass of horny or jelly-like tissues is supported by a maze of stony spicules. In shape they are like rods, bows, anchors, pick-axes, arrows, snow-crystals, stars, crosses, prongs, boomerangs, forks, triangles and needles. They are sometimes arranged in beautiful order, or again scrambled regardlessly through the sponge like piles of jackstraws. They may be made of silica or lime, or as in the case of bath sponges, replaced by a framework of horny consistency.

Consider, for a moment, the amount of silica in seawater, less than two parts in every hundred thousand. And yet the tangle of spicules in sponges is derived from this infinitesimal amount. To form a single ounce of silicious spicules the patient sponge has to swallow a ton of water. We know nothing of the process; we can imagine only 


\section{SPONGES}

some of the magic of chemistry, working with a formula of sea-water and time, stirred with a mysterious life process which was in perfect working order five hundred millions of years ago, when the complex spicules of Cambrian sponges were manufactured. In past ages sponge spicules have been responsible for considerable geologic deposits, and more recently they played a part in the battles which were waged between our grandparent pioneers and the red Indians, - the flints of the arrowheads and the flints which struck sparks from the triggers of the muzzle-loading guns.

One day in April when I had dived until I could stand it no longer, I drifted closer to the main reef of Lamentin, and anchored just over a giant sponge. I had already made its acquaintance, and named an adjoining coral road "Sponge Alley". I had watched the life in and about it from a distance, had squatted beside it, observing it at close range, and finally sat upon it to rest, and to transcribe these notes with pencil upon a plate of zinc. It was larger than a half barrel and canted slightly to one side. I sent down one man who prized and cut it loose, and tied a rope around it. It was so heary that he could barely lift it free of the bottom, to make the rope slip beneath. IVe drew it to the surface, but once out of water the combined efforts of four of us failed to get it over the gunwale. So down it went again, and when several hundred pounds of coral had been chopped out of its base, we had another try. This time, dealing 


\section{BENEATH TROPIC SEAS}

with the pure culture of sponge, we were successful. After it had been in the boat for two hours, and all the superfluous water had drained off, its weight was a little over one hundred and fifty pounds.

On every reef there are from two to six of these giant black sponges, growing at depths varying from twenty to thirty feet, and in the history of their inception and growth is concealed a marvellous tale. The adventures of the tiny swimming embryo, favored by some inconceivably slight chance over the uncounted host of its fellows; its random selection of just the right bit of coral upon which to grow; the accidents which did not quite come off to blot out its existence; its ultimate victory over the myriad dangers of the undersea,all this would make an aquatic epic. I feel as if I had only handled the uncut, untranslated volumes of such a tale, in my discovery of the sponge in its native haunts, my intimacy with it as it still rested quietly in position on the sea bottom, and my subsequent excited search among the heart of its canals for whatever secrets might be vouchsafed. I can only guess at its age, but many years, perhaps centuries must have passed since the all but invisible young sponge settled down, exchanging its winged frill for an everlasting, grasping root.

There was some superficial thing, some animal nettle, on my sponge which fought for its host by shooting a myriad harpoons into the hands of the first of my men to touch it. But the sting soon 


\section{SPONGES}

died out, and the sponge itself was as innocuous as a mushroom. Before we disturbed it I saw that two fish called it home. First, an elegant, scarlet-banded squirrel-fish which now and then peered out from the deep hollow beneath the body of the sponge. Its great eyes were darkened like those of a Spanish dancer, and the red on the gillcovers came and went with the blush rhythm of its emotions. And secondly, a pugnacious little demoiselle, clad in sombre brown, picked out with azure stars, had taken possession of the open center of the sponge itself, and relinquished its tenancy of this round, living patio only when the sponge began to rock on its very foundations. When the floors of some old house have been torn up, I have seen a crowd of little boys run in and excitedly search the ruins for any lost things of old-coins or buttons or baubles - which might be brought to light. In the case of the sponge, hardly had the great organism been rolled over, when a score or more of greedy wrasse rushed in and gleaned among the débris.

I hoped for parasites and for tenants but not until I began to pull the sponge apart, did I realize the multitude of pulsating lives in these hidden catacombs. After a few experiments $I$ found the best way was to cut off slices, cake-like, from the sponge, and tap them gently into dishes. From each slice, about four by four, by one inch thick, I secured an average of twenty shrimps, with rarely now and then a crab. There was no dim- 


\section{BENEATH TROPIC SEAS}

inution of numbers even in the very heart of the sponge, and no matter in what direction we cut, the pale whitish bodies of the shrimps would appear.

When I thought that most of the inside news of the sponge was used up, we came across two tiny fish, and the enormous mass took on renewed interest. Two slim gobies, less than an inch long they were, pale below, with a series of ten large blotches along the back, but the moment I put them under the microscope I saw that they fairly bristled with remarkable characters, adapting themselves to life in the narrow byways and winding mazes of the sponge. I found five of these fish altogether, their bodies of an even diameter, which would enable them to go in and out of all but the smallest holes in the sponge surface. So these, unlike some of the shrimps, were not prisoners, but could wriggle out at will. Only one was found more than six inches from the surface, and in this case, three shrimps were in the way, who must be passed before the outside grating could be reached. The head was remarkably small, and the eyes tucked away well toward the top of the head. Both the long pectorals and the united ventral fins were extremely worn and torn, the webs not frayed, but the tips of the rays themselves broken and lost. This was plain evidence of the change of function of fins in these little fish, from swimming to climbing about the roughened sponge channels. Most astonishing of all, however, was the devel- 


\section{SPONGES}

opment of specialized digging or climbing scales. On the body as a whole the scales were absent or so slightly developed as to be quite invisible under a lens of low power. Yet, abruptly along the lower posterior line of the sides, there appeared two series of about ten large scales, the edges of which were developed into long, strong, brown spines. There were ten on each side, well separated, and four on the midline behind the anal fin, and no more perfect climbing battery could be imagined. It was difficult to see how this sponge goby could ever go backward, for every wriggle must mean an advance. So like a worm or eel was its form, however, it could probably turn in its own width. Every time I examined this strange fossorial apparatus, I was reminded vividly of some similar device I had seen elsewhere. At last it flashed into my mind,- - the marvellous digging hands of the white mole crickets of Kartabo. In color, shape and function the two were very close,-in structure and origin as far apart as the poles. While this goby was quite distinct, a new and as yet unnamed species, it is closely related to one which has been found in a sponge off the coast of North Carolina of the genus Garmannia.

When I pressed on any portion of the sponge, and then relaxed, a weird little chorus arose. At first I thought it might be the water and air fighting for possession of the cells, but the metallic quality of the clicks soon told me that a host of little snapping shrimps were protesting at the dis- 


\section{BENEATH TROPIC SEAS}

tortion of their homes. I cut off a generous cube, placed it under water, and listened to it about midnight when the water was so still that there was not even a ripple at the bow of the schooner. Even with my ear against the surface of the sponge, then of the water in the aquarium, and finally against the glass itself, I could hear nothing. I took the piece of sponge out, and within five minutes, while the water drained slowly from it, I heard seventeen distinct clicks. Two were of different timbre, even to my coarse hearing, but I could make no distinction between the others. When isolated in a small glass of water, these shrimps produce a snap which is so penetrating that it can be heard fifty feet away. If a piece of sponge is dropped into a dish of formaline the dismayed chorus sounds like several bunches of tiny Chinese firecrackers going off at once. I was never fortunate enough to detect any variation in a single individual of this monotonous method of communication.

There was no question of the decided character of the emotions of the small folk, when the water began draining away in earnest from their chambers. Click, click-click, came sharply from some suite in this astonishing apartment house. Click, click, click, echoed the answer, "Our plumbing'sgone-wrong-too" from a neighbor.

I kept tally of fifty shrimps, and found that in eighteen cases there was a male and female in the same chamber, nine males seemed to be living 


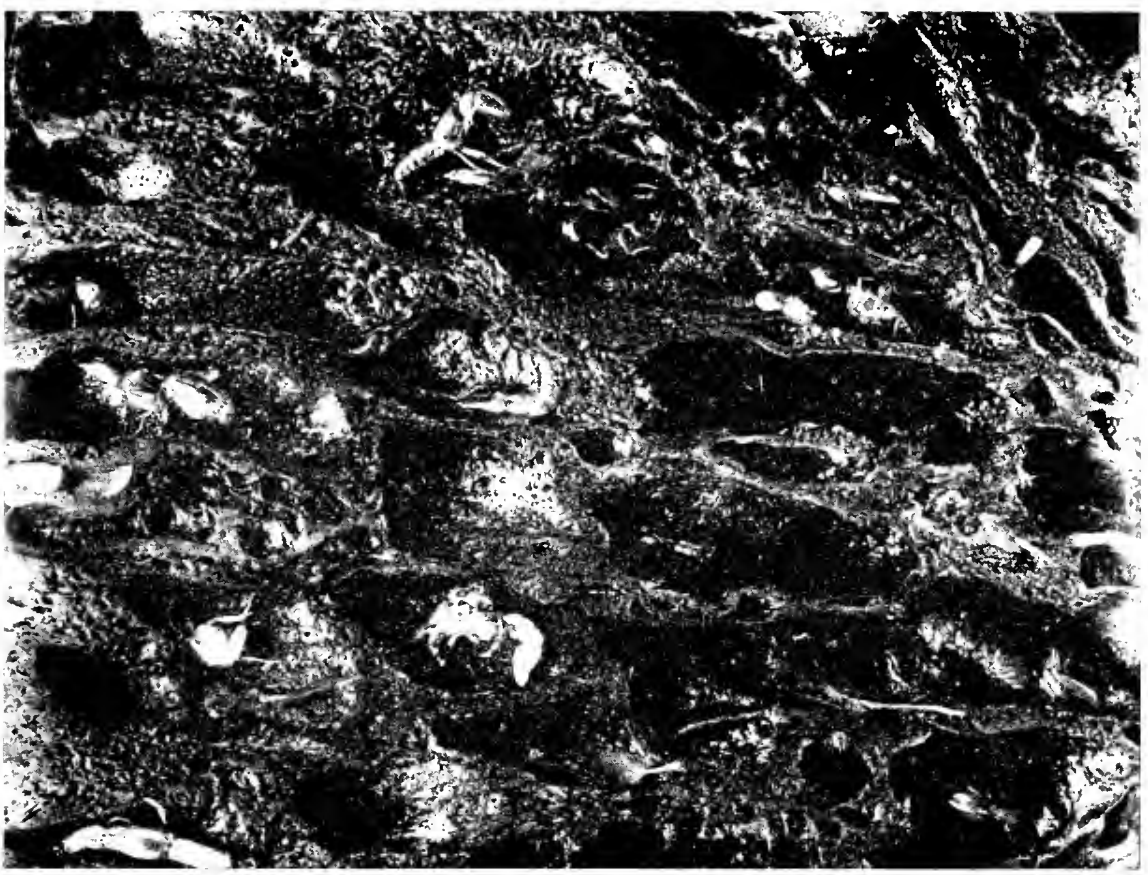

Section of Giant Sponge Showing Snapping-shrimps and Crabs Living in the Internal Chambers

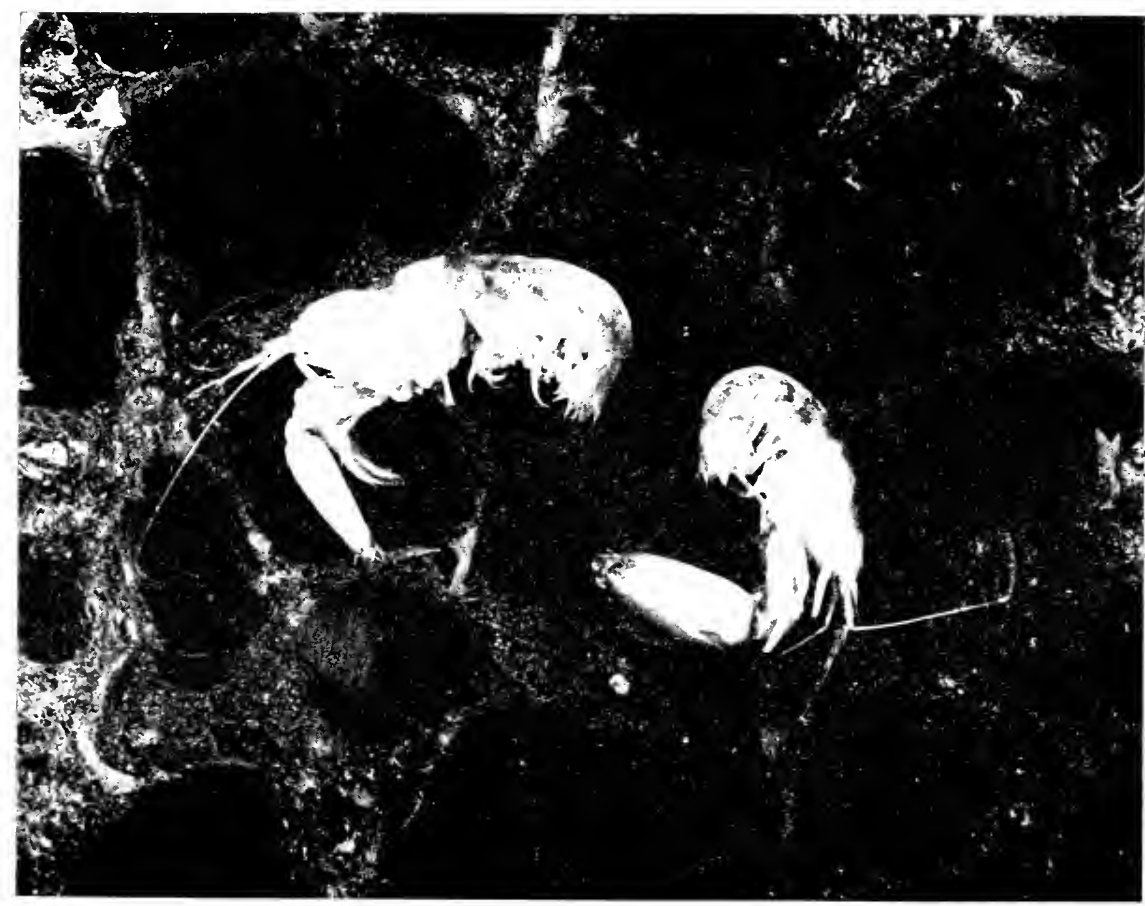




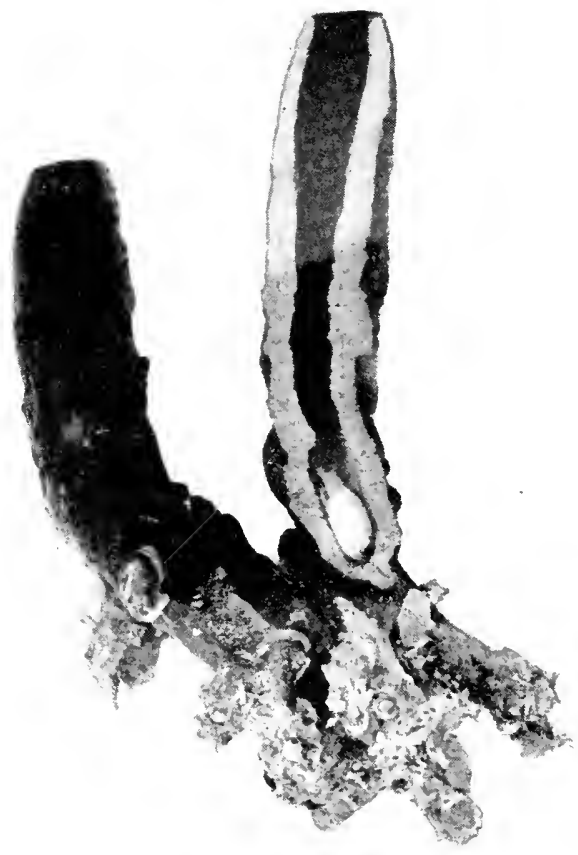

Cardinal Sponge-Fish, Amia, in Bottom of Chimney Sponge

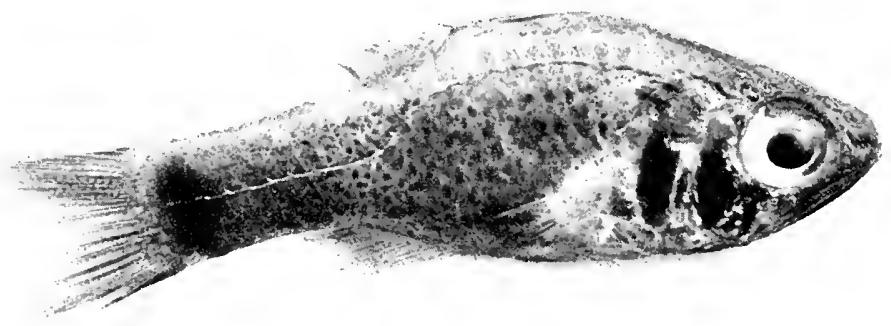

Cardinal Sponge-fish, Showing Generalized Pigmentation, and Nocturnal Character of Large Eye 


\section{SPONGES}

bachelor lives, three females dwelt in solitary maiden state, while two male shrimps were each in a large compartment with a jolly, little, ruggedarmed, red-and-white crab. The evidence is against the old maid snapping shrimps however, for all three of these solitary females had a pocket of welladvanced eggs.

When a piece of the sponge surface was left undisturbed in an aquarium, the pale inmates could be observed, after a while, creeping slowly up to a group of small holes at the end of each internal canal, apparently looking out, exactly as the occupants of prisons and asylums may be seen peering through the bars. A sudden movement on my part, even some distance away, sent the shrimps scurrying down their dark alleys out of sight.

I placed three pairs of shrimps under water, undisturbed, in their original homes, and then annoyed them, and my respect for this race of little beings rose when, in each case, I saw the males advance to attack me, the fact of my being millions of times larger and stronger restraining them not at all. One crustacean gallant scrambled over the body of his spouse so roughly in his efforts to reach and rend me, that he rolled two of his offspring out of their protective covering. The eggs are a most beautiful pale green, the youngsters showing through the translucent film as greenish white.

There are many species of these snapping 129 


\section{BENEATH TROPIC SEAS}

shrimps, and they are happy in their generic name of Alpheus, - the river-god who was the son of Oceanus. Only one of their claws is developed into the great snapping affair, some being right, others left handed. When taken out of their spongy homes, they are shy, and not until I watched them, late at night, in a dull red light, did they assume it dark and safe enough to become active and reveal their true characters. I placed a half dozen, both males and females, in a small dish, and found that I had started a battle royal. The snapping, it seems, is only one use of the great hands. I watched two male shrimps approach one another, warily, with now and then a mutual retreat. The big claws were held straight out in front, and first one, then the other, would open fire with the trigger finger, spreading it wide and suddenly snapping it shut upon the stony thumb with the usual loud click. This kept up for some time, the blank cartridges doing no harm, recalling the old Chinese battle methods of beating tin cans and making faces.

At close quarters the dud clicks ceased, and a sudden mêlée ensued, too quick for the eye to follow. An instant later, the left-handed warrior turned swiftly, struck sideways with the sharp edge of his huge hand, and actually severed the claw arm of his opponent. The latter held his ground, and continued for a few seconds violently to wriggle the stump, seemingly unaware that his weapon had been shorn away, then fled headlong. 


\section{SPONGES}

I had to leave them at this point and in the morning four of the right-handed shrimps were dead, the fifth quite disabled, while the left-handed inchling d'Artagnan was triumphantly waiting to attack me if I came too close. He had lost one of his second pair of legs, although he did not appear to know it. The snapping is thus but an empty threat or a challenge while the sabre swing of the whole claw is a most efficient gesture of offence.

Most of the clan of Alpheus live their lives in crevices of coral or under sea-weed, and are clad in brilliant colors, while their brethren in the black catacombs of the sponge have shed their useless Joseph's coats, and are garbed in pale lemon or ivory-white with only rags of rosy trimmings and claw decorations as hints of former glories. In still more important ways they have become adapted to their new environment. I have captured a blue and violet female snapping shrimp on coral, only a few feet away from the giant sponge, which had nearly five hundred eggs in her pouch. These hatch into tiny, swimming larvæ, the first stages, as in the fiddlers, known as zoëa, and the later ones as megalops. After considerable time spent in swimming, day and night, carried perhaps far away on tidal currents, they settle down to adult snapping-shrimphood, adjusting themselves to almost any kind of reef bottom. But in the sponge shrimps, the females never carry more than twenty eggs, sometimes only seven, all large. In 


\section{BENEATH TROPIC SEAS}

these the young pass through much of the swimming stage, with swimmerets developed, but functioning only in ancestral memory. When at last they are swept out of the sponge mouths, the shrimplets are able to swim only for a brief period and a short distance, and every atom of their energy is directed toward finding a new, habitable sponge. Death is the only alternative. Their abbreviated youth ensures at least their continuing in the vicinity where sponges presumably thrive.

The odds of the game of fate and chance are followed closely by the gods of the little shrimps, and the play is to the limit. We can be fairly certain that the difference between twenty, and five hundred eggs expresses very exactly the ratio between the dangers of a free-swimming life, and the possibility, during a brief search, of finding and diving into a life-long sponge sanctuary. If we assume for argument, that in a single brood, the annual increase of shrimps over the deaths is a single individual, we know that at the most critical time of life, four hundred and ninety-nine of the free-swimming, snapping shrimps must succumb, while of the sponge livers only nineteen fall by the wayside.

We can tramp about the sponges on the floor of the ocean, and excavate their inhabitants; we can watch these shrimps for a time in aquaria, and can dissect their bodies, but it is only by such hints as the difference in the size and number of eggs, and the length or brevity of their youth, that we 


\section{SPONGES}

may hope for light, even though indirect, upon the vicissitudes of their lives from birth to death. When once we grasp the vital meaning of such facts, we are on the track of a law which holds good, not only for infant snapping shrimps, but on up the ladder of life to the topmost rung, to which we find ourselves clinging precariously during our few years of consciousness upon this planet.

After this solemn, sonorous apodixis let the word sponge bring to mind, not only the pleasantly squeezable accompaniments of our bath, but the wonderfully colorful race of living creatures dotting the coral reefs of the world, much as elumps of violets and marigolds brighten our terrestrial gardens. 


\section{CHAPTER $\mathrm{X}$}

CORAL JUNGLES OF SEA-COW REEF

Early on a Wednesday in March I prepared for an exploring visit to Lamentin Reef, but as I went down the gangway I found that I could see the bottom of the bay in our new anchorage, sixty feet beneath the schooner. It was a faint reflection and no clear details were visible. I decided to make a record dive and improve on my descent of forty feet in the Galápagos.

A rope, with a weight on the end, was lowered from the gangway platform, and with two lengths of hose joined together and a husky man at the pump, I was helmed and slid slowly down the line. The great hull of the Lieutenant curving away into dimness was all covered with a dense growth of sea-weed and various reef animals. A great school of Aurelia jellies brushed slowly past, but as the hull faded to a dull shadow I fixed my mind on the mass of water below. At my last upward glance, part of the black shadow swerved outward toward me, detaching itself and fashioning into a twenty-five foot shark. To be sure, when I scrummaged into a ball on my slender rope and looked carefully, the oncoming selacian dwindled 


\section{CORAL JUNGLES OF SEA-COW REEF}

to about a third of my first estimate, and two young ones showed more curiosity about me than she did. They soon melted again into the schooner shadow and I was alone. Then my rope twisted slightly and I found myself gazing at a huge bit of shark bait on a hook and line dangling from the aft deck. In my present pose, crouched into a ball on my own rope, there was altogether too much resemblance to the object in front of me, so I promptly unrolled and slid down.

The shark bait proved to be my last touch with the upper world. Slowly I slipped down and down, and, for all definite feelings, I might have been just one additional translucent aurelia floating in the turquoise ether. Now and then a tiny but active jellylet brushed against the glass of my helmet, and I involuntarily swept it away as one would a cobweb or a gnat in the upper air. Then, without warning, I was aware of having less adaptable organs of sense than the casual jellies, and a needle-sharp pain shot through my right ear-my old airplane ear. I scrambled up a yard or two and began to swallow and wobble my neck about. Then I opened my mouth, depressed my tongue and said $A h-h-h-h-h$ as I do for a tonsilinterested doctor. Soon there came the reassuring little squeak of equalizing air in the Eustachian tube or somewhere in my head; the pain vanished and I went on. I slid more slowly now and did not have to delay again, except when my pet school of Caranx latus swept past-seven left of 


\section{BENEATH TROPIC SEAS}

the eleven which had first made our keel their happy hunting ground. Three times they repassed, and circled once before vanishing.

On and on I went, with only the slowly ascending hemp spiral to make real the passage of space. I felt I was taking an unconscionable amount of time, and had descended only a few yards beneath the schooner, when my feet struck the three-link weight which hung at the end of the rope. The thrill which marks the unexpected arrival at a goal was mine, and did something to my ears, so, like a monkey on a stick, I shot up again. In a few seconds I was hanging from the last link, my feet sinking in soft, age-old ooze. Even throu $\mathrm{h}_{1}$ my rubber sneakers I could feel the silky, almost oily smoothness. The light was surprisingly good, my ears were quite normal, and I sensed my position vividly. I kneeled down and found I was in a chamber of visibility about ten feet square. In the surface of the slime were many small craters sheltering unknown occupants. At my feet and scattered liere and there, appeared great maggots of holothurians, worthy tenants of this world of ooze. Each had a pattern and to prove my goal, I selected the most colorful and squeezing it into dumb-bell shape I caught it netsuke-fashion in my belt. Climbing slowly, and swallowing as I went, I made good time and at last lifted my seacucumber prize aloft above the water-an echinodermic Excaliber. My next goal will be one hundred feet. 


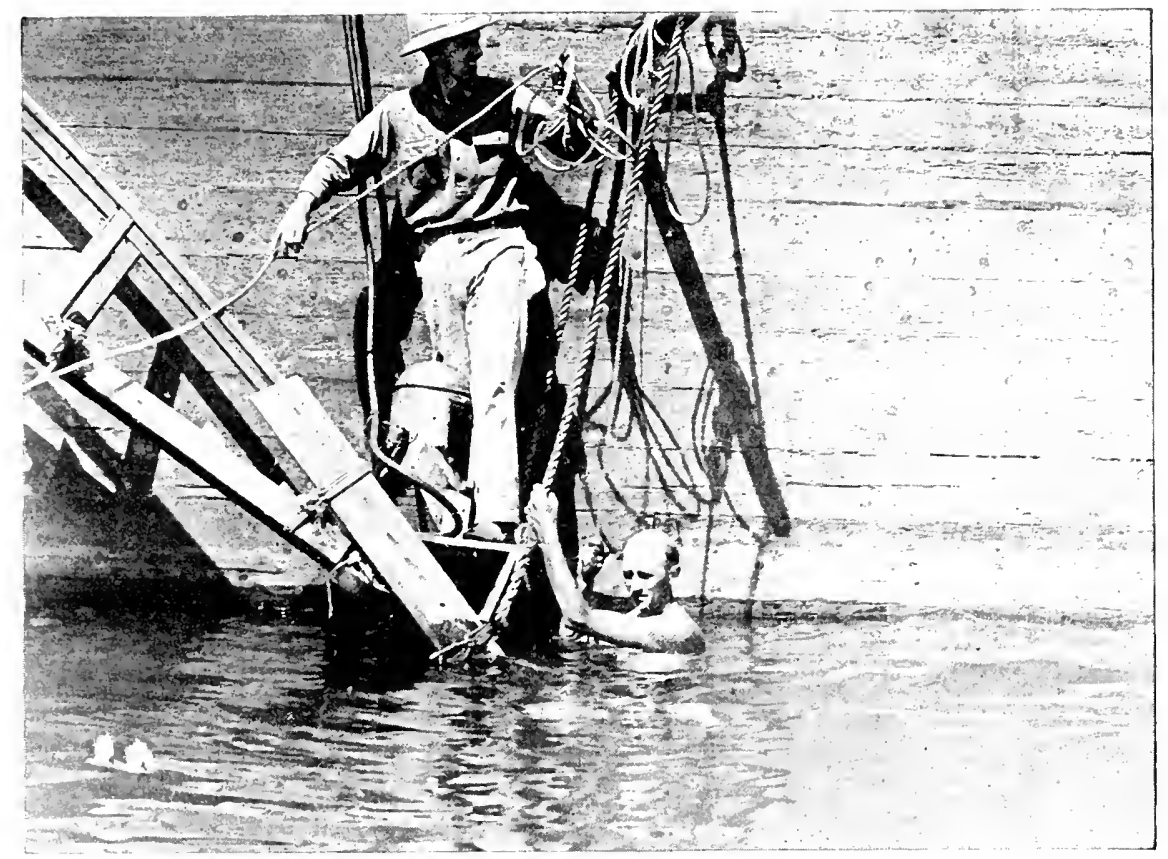

William Beebe after Ascent from Sixty-foot Dive at the Side of Schooner
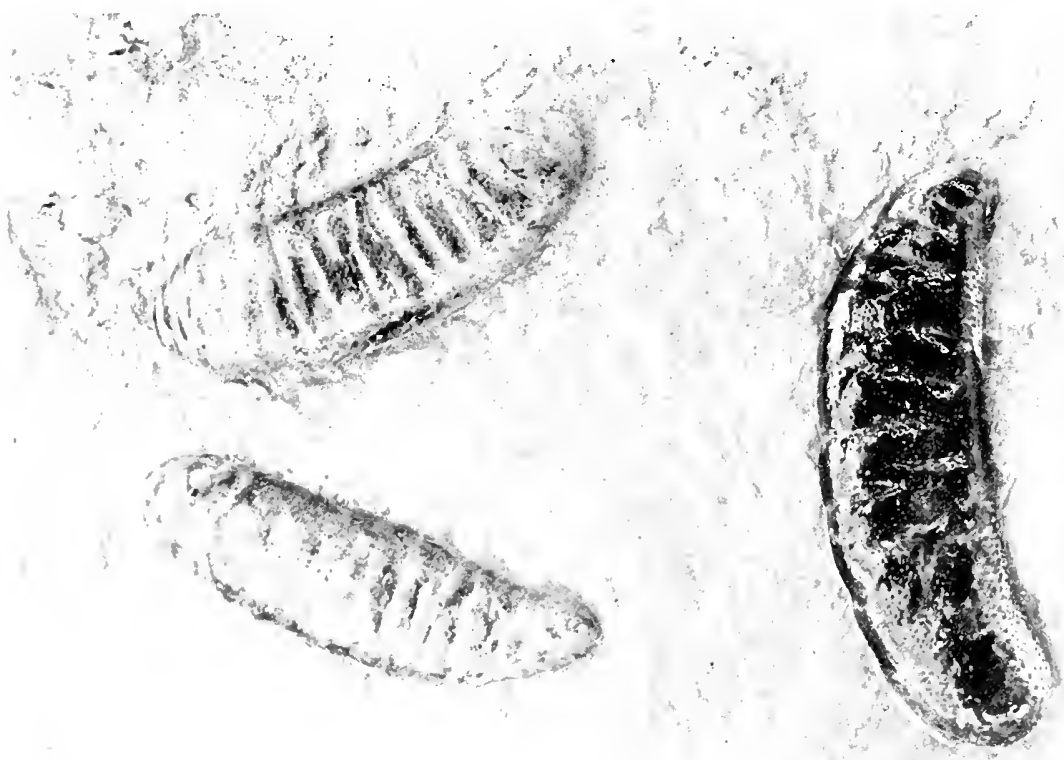

Reconstructed View of Soft Ooze and Sea-cucumbers Collected Ten Fathoms Down 


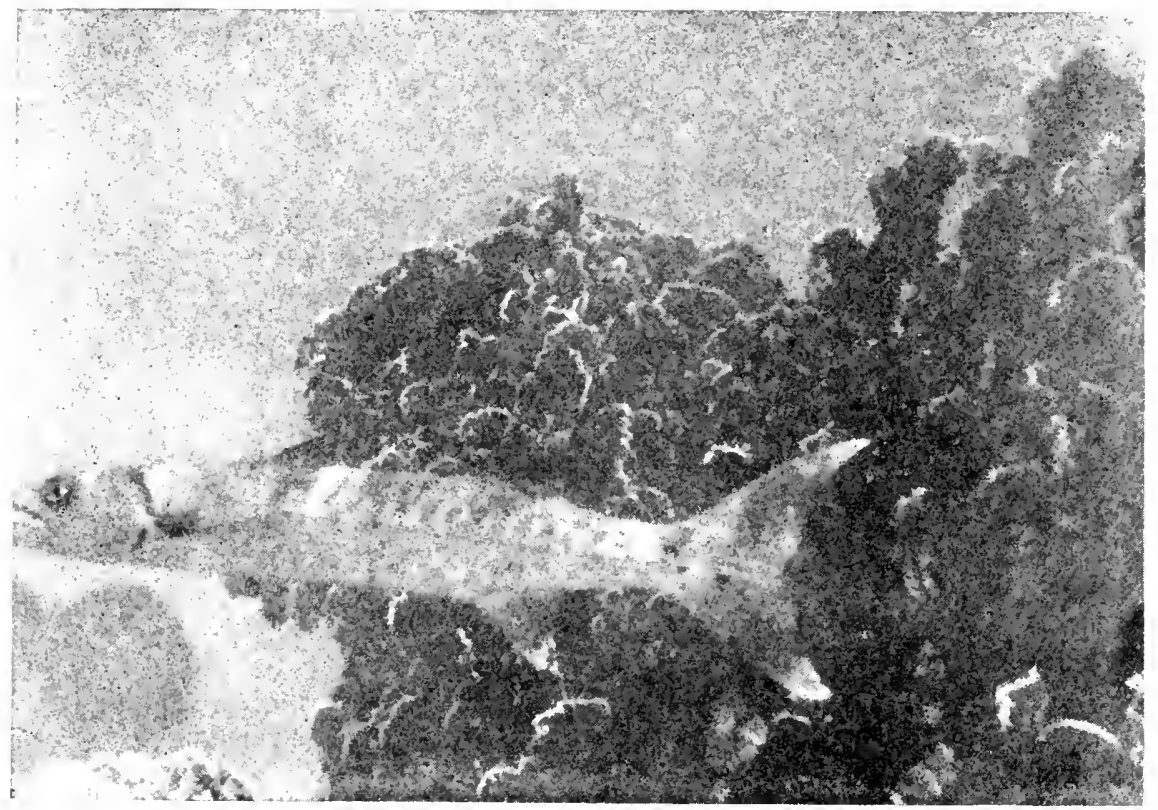

Barracuda Swimming Past the Camera

Enlargement of cinema film

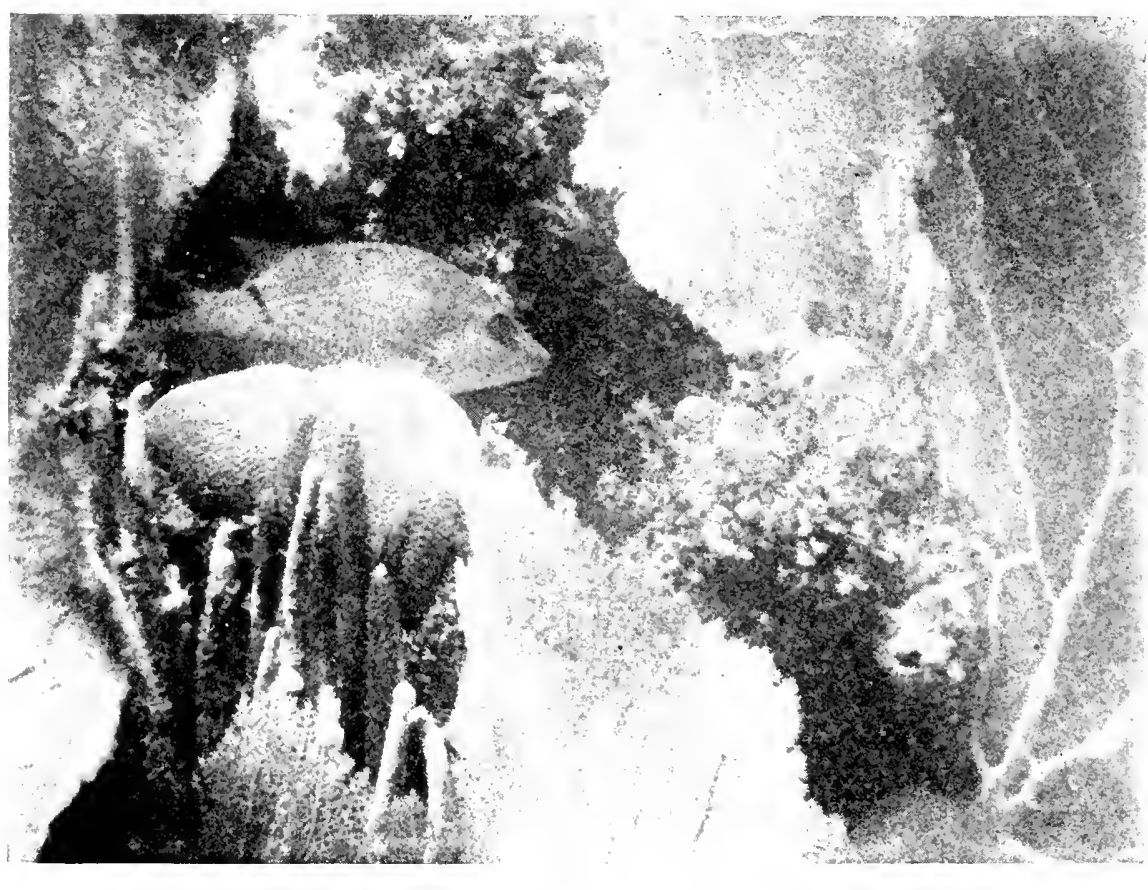

Coral Cave Several Fathoms Down, Showing Purple Sea-fans, Gorgonias, Coral-heads and Grey Snappers 


\section{CORAL JUNGLES OF SEA-COW REEF}

When my sea-cucumber and I had rested from our unusual experience, I examined him more attentively. I got out a key to West Indian seacucumbers and from the fact that he was over a foot in length, lived in the mud, was olive-buff dotted thickly with clove-brown, and the happy possessor of twenty tentacles, and with hundreds of tube feet arranged in three series, I was able to call him by his correct scientific name, Stichopus mobii. For an organism which, in the bloom of perfect health resembles a giant maggot, the euphony of this binomial is not amiss.

A new lot of fish was calling for my attention, but I neglected them for a few minutes longer. I took a lens and surveyed more carefully my fellow tenant of ten fathoms down. His skin was knobby and thorny and olive and brown, and in a hundred places I saw tiny stems supporting circles of delicate tentacles. At first I thought of these as some minute structure of the holothurian itself. Then I took a pair of forceps and, almost at a touch, off came the hydra. More and more and more hydras were found-lowly cousins of sea anemones, living happily on this great creature, as gnats might perch upon an elephant. I placed four hydras under my microscope, and the very first one I looked at had a bulging parasite near the middle of a tentacle. "And so ad infinitum" I chanted, then turned the cucumber over to my preparateur, and began on my fish.

One windy day we took the motor boat and went 


\section{BENEATH TROPIC SEAS}

a few miles down shore. The water was choppy and, to an unaided eye, quite opaque. The lighthouse passed astern and a big bay opened out before us. Several natives were fishing and a flock of pelicans watched and dived and rose again. We put a water bucket overboard, threw up the blinds of the wave-marred surface, and discovered Lamentin or Sea-cow Reef. Unlike Sand Cay it was of a barrier or shore fringing type, and lay parallel with the land, about four miles west of our schooner. Also, unlike Sand Cay, its sea-fans and gorgonias were subordinate to its corals-massive brain mounds as big as automobiles, and elkhorn forests twelve and fifteen feet high.

We found a beautifully graded transition from land to deep water, and took elaborate notes for future technical papers. The cocoanut palms gave place to a fringe of mangroves with their toes wet by the high tides. Then came a sandy beach reaching beyond low tide, next a zone of short, hair-like grass, and a wide area of Thalassia or eel-grass. Rather abruptly this merged into the reef. The inner side of the reef was level and shallow, wadable at low water. Small heads of coral grew here-nubbin, branched and millepores.

I found life in great abundance, and many forms that did not occur farther out. Under every bit of coral swarmed starfish-black, red, pied, grey, orange and purple. Sea-urchins vied with them in numbers,--long, needle-spined chaps, short, stubby club-spined ones, and others fashioned like 


\section{CORAL JUNGLES OF SEA-COW REEF}

chestnut burrs. With these were hosts of hermit crabs, small worms, infant fish and octopi.

Farther out, there came an abrupt drop to several fathoms, the barrier wall being tall growths of elkhorn coral, down which, with care, we could clamber to the general reef floor. It did not do to attempt this in any but a calm sea, for every helpless toss against the stone-thorned branches revealed the pitifully thin-skinned defence of our bodies.

It always seemed that in the places most difficult of access were to be found the greatest prizes. The Isopora or branched corals, grew in a ghostly tangle of cylindrical, white thickets fathoms down, quite impenetrable. As they neared the surface the branches flattened into the moose-antlered type, and grew less closely together. I ventured, more than once, to creep down into these tangles of coral branches, testing each before I put my weight on it, and striving to keep my hose free from being jammed and perhaps torn in a crotch. In the open reef, no matter what happened, one could always lift off the helmet and swim up, but here there was a cruel, interlaced, cobweb of sharp-edged ivory overhead, and escape was possible only by slow deliberate choice of passage. As I painfully made my way down nearer the level of the ground corals, I encountered portières of the stinging millepores. When I reached these I unslung the hammer at my back and pounded off the outer layers, and there, like jewels in a geode, 


\section{BENEATH TROPIC SEAS}

were occasionally to be found tiny trees, an inch or two in height, of the exquisite and rare pink coral. I do not remember anything in my undersea experience which gave me more sheer æsthetic joy than spying out these beautiful bits of colorlooking like the diminutive wind-blown pines of Fujiyama.

Again and again on these reefs, although the general effects are all on a big scale, as I sit on a bit of sand between great animal forests, I see Japanese gardens. When I walk through terrestrial gardens, whether old-fashioned or overlandscaped, it is man's height masses of color which form the character of the garden and the pride of the owner. Has no one, I wonder, ever cared to have literally a squatter's garden, one which has to be knelt to, in order to discern the tiny blossoms, or detect the evanescent odors? My pink coral trees made such a thing real and very desirable.

When clouds prevented photography, and a swell made. climbing too hazardous and bloodletting an enjoyment, I would break off and send up great branches and heads of half-dead coral from the débris of the reef floor. From where I sat, where there was not sufficient nourishment or protection for the coral to grow luxuriantly, the aspect would be characterized by sombreness-browns, dull purples, sage greens.

But when we began to break open the coral débris sent up to the boat, Aladdin's caves were 


\section{CORAL JUNGLES OF SEA-COW REEF}

everywhere, and our eyes were flooded with imprisoned rainbows and spectrums. The flower worms, buried deep in the stony lime, glowed with hues from red to violet, their clustered gills revealing concentric rings of color like those of our grandmother's bouquets; the sea shells, dirty white outside, when opened glowed with sunset pink and opalescence; crabs were hiding in filched shells, which in turn were in coral chambers from which there was no escape, and the colors of their legs and eyes defied human names; mantis-shrimps imprisoned behind zenana-like windows of the sponge gratings, reflected, from antennæ tips to telson edge, all the subtle shades and hues which dodge in and out between the primary and secondary colors of the earth.

On Sea-cow Reef where the corals thin out, there appeared in force the more pliant ferns and nets, fans and plumes of gorgonias. Tall, slender clumps had exactly the manner of growth of candelabra cactus, but covered with a dense polyp fur of clove brown. Some of the fluffiest stung at a touch, and, at the same touch, withdrew every polyp, leaving bare the rich purple trunk and branches, - an emotional autumn of fear which swept over the full-blown foliage swiftly as a shadow. Indeed, a shadow alone will work magic with supersensitive polyp tentacles, and the animal forests shaded by the hull of my boat floating overhead, were, judged by the foliage of terrestrial plants, a month behind their fellows in the sun. 


\section{BENEATH TROPIC SEAS}

The fretwork gorgonia fans were frequently abraded, or showed great holes torn or worn in their substance. To my delight I found that these were used as scratching places by passing fish; the parrots especially enjoyed oozing slowly through these tears and rubbing back and forth against the broken ivory strands. I shall never forget looking up at a great sheet of purple grill stretching across my path, and seeing the head and pectoral fins of a blazing parrotfish projecting from a jagged hole. It watched me calmly from its perch, and backed out reluctantly only when I approached it too closely.

After the fish had left I continued to watch the gorgonia, pondering on its resemblance to vegetable growth. I was astonished to see the tips of some rather thick branches suddenly blossom into a field of white star-flowers. I now saw that these branches did not originate from the main stem, but began abruptly in mid-network, gaining strength and rotundity, and shooting out beyond the limits of the fan. As a jungle tree throws branches about some fatal parasite which is irrevocably covering it, so the gorgonia polyps had bravely grown their purple bark about the encircling tubes, but these pink and white worms thrived apace, shooting ahead in their tubes like slow motion sky-rockets, finally, high above their host, to burst into a blaze of snowy tentacles.

One of my favorite diving places on Sea-cow was along the outer edge, where the reef dipped into 


\section{CORAL JUNGLES OF SEA-COW REEF}

the breathless mystery of deep water. Here, in five to seven fathoms I would submerge until I was blue and shaking, then come up cursing my bodily limitations.

It was the most Galápagos-like place I had seen. But the walking was terrible, almost like clinkerglass lava, over sharp, up-ended coral, which would break off sufficiently to let one's bare legs slip down and be gashed on the razor edges. Here and there were small sand patches, deep hidden between staghorn branches, and the whitest of nubbin coral, which, like beds of sweet alyssum or candytuft, carpeted every vacant spot. Underneath was the fallen débris of years,- -rotting coral branches broken off high overhead by mighty storms, overgrown with lichen-algæ, sponges and mock-moss. On the animal hillsides blossomed great variegated worm blooms, more delicate than any orchid, while lesser flowers-mauve, pink and scarletmarked the trap-door worms, which far outdo the spiders of the earth, for these doors are part and parcel of the worms, and close automatically.

I climbed six feet up a coral mountain and crouched behind a chevaux-de-frise of fret-work panels, hewn out of sheer ivory, and as I well knew, not-to-be-touched, because of glass edges and stinging cells. I now looked down and down from the visible reef rim, down into the void of the sea,-into that absolute blueness which leads the eye on forever, yet conceals everything. It was like night reversed, that sky darkness which 


\section{BENEATH TROPIC SEAS}

seems impenetrable at arm's length, and yet suddenly reveals the moon and distant stars.

As I climbed I dislodged several coral boulders which fell slowly past me. An avalanche undersea could only be described in slow motion terms. Small fish, like vultures about a fallen chamois, gather at once, but unlike even the swiftest vulture, they are around and under and atop of the rolling coral heads long before the latter have come to rest.

For the next many minutes I used very little of the oxygen from the air faithful Serge was pumping down to me, for I sat quiet, barely breathing. Out of the blueness, blurred forms came, small and large. I was reminded of the time I was caught at early dusk in a salt plain in south Ceylon, and crouched, watching several foggy forms, hoping they were boars, fearful of their being wild buffalo. Only now I did not fear, I simply watched with the same absolute concentration and joy which every entrance into this no-man's-land filled me. Before long, I saw more clearly, and a mob of huge parrotfish came into full view, working slowly toward me, feeding and idly wandering about as they came. They drifted around a coral spur, but before the last straggler vanished, the vanguard appeared again out of the distant brilliance, and now their numbers were augmented. I counted up to one hundred and thirty-nine, and then realized that three hundred would be within reason. None were less than a foot, while most 


\section{CORAL JUNGLES OF SEA-COW REEF}

were more than two feet in length, and at least twenty measured a full yard. They were chiefly of one species-a Pseudoscarus, known at any distance by the great, green, parrot-beak teeth.

They reminded me of the surgeonfish of Galápagos, with apparently nothing to fear, and they sauntered, with absolute casualness, back and forth, working, however, steadily ahead. Twice they circled me and I was impressed with the strange details of this strange world. Never before had I realized the chameleon character of the parrotfishes' eyes. When several of the huge bodied creatures had passed me, and when there was presented only an extremely foreshortened rear view, I could see that they were still watching me. It was most uncanny and only in wooden dolls could such a thing be thought possible. The whole eyeball rotated so far back that only a portion of the pupil projected from the socket.

The strength which these fish exerted in wrenching off a head of coral was astonishing, and every time, a swirl of lime débris would ascend like a dust cloud. In and out among the fish dashed a school of wrasse, intent on securing the crumbs. But most amusing were the attacks made on even the largest whenever they stopped to feed, by tiny demoiselles who feared nothing that swam when it came to defending their homes. To see a threeinch black and yellow fury driving full force against the side of these blue enameled giants was to see courage at its height. And when the great fish 


\section{BENEATH TROPIC SEAS}

had torn off its titbit, it good humoredly allowed itself to be butted aside, the general effect being of a single tiny tug striving to nose the Île de France into mid-stream. Although I have seen such fish as gar and barracuda thus attacked, I have never seen them turn upon their midget assailants and swallow them at a gulp as they could do so easily.

In the midst of one of these encounters, while several score of the green-beaked parrots were gathered about me, I saw the blue distance give up another great form, and a six-foot tarpon,the king of the reef,-grew into solidity, swam ioward me, passed unnoticed through the school of parrots, and almost immediately dissolved again.

More than ever before I was impressed with the difference between the world of fishes and my own. We both possess three dimensions, but in comparison with theirs, ours is a realm of but two and a quarter. The great enameled forms before me rose and fell, circled, approached and receded, all with equal ease. We likewise can run to and fro, but for the rest must leap and climb laboriously, or fall with danger to life and limb.

Within a few minutes of sighting the first of the school I was completely puzzled by a remarkable habit. A parrot would scull slowly up to a small head or branch of coral, deliberately take it in his mouth, and by some invisible muscular turbine movement break it off. Moving away a few feet, 


\section{CORAL JUNGLES OF SEA-COW REEF}

the great fish would then upend,- -head up, tail straight down in mid-water, and hang there. I watched carefully and saw no movement of the jaws although the mouth was open. For several minutes it would remain suspended and then move off to another coral titbit. Many times I have seen these fish push with the pectoral fins, leverlike, against adjacent coral to give them greater wrenching force in breaking it off. During the period of verticality, and internal mastication, if such it was, a school of little wrasse darted out and thoroughly cleaned cheeks, lips, teeth and scales of all particles of organic coral débris, the parrotfish remaining quite motionless all the while. It was an aquatic parallel of crocodile and plover, cattle and egret, rhino and tick-bird.

When we have watched and watched, when we have fished with every imaginable bait and hook, when we have netted and dredged, lured with light and shot with tiny harpoons, then, when finally we still see strange and beautiful fish quite unknown to us, we stoop to pothunter's methods,securing sticks of dynamite and detonating caps.

On one of my dives I discovered a coral castle of marvellous beauty. The simile was more than an empty phrase, for in outline, in castellated battlements, in turrets and an astonishing mimicry of a draw-bridge the comparison was irresistible. Even more exciting were the tenants, for in addition to the usual demoiselles, butterfly-fish and gobies, there was a school of most exquisite beings. 


\section{BENEATH TROPIC SEAS}

They were only two inches in length. Although resembling the demoiselles in general appearance, we found later that they were actually diminutive sea-basses belonging to the genus Gramma. The anterior two-thirds of the body was rhodamine purple, the head, jaws, scales and fins being equally deep colored. Abruptly, the remaining third changed to glowing cadmium yellow. But all this detailed description is forgotten, when we see the living fish, and we feel only an inarticulate appreciation of the fairy-like beauty, as we watch the school swimming in and out of their coral castle.

By guiding signs on shore, a cocoanut palm just below a notch in the second range of mountains, and one native hut lined up with another, I was able to return to this wonderful castle of coral and to study it throughout many dives. Again I went down and squatted and watched, and again I saw the paradise fish-evanescent, long-finned, with pigments so beautiful they will never desert the memory. Six of them floated slowly back and forth across the mouth of a great half-open cave beneath the castle's crags. At my feet was a wire trap baited with over-ripe bananas, soggy bread and succulent sea-urchins. Around it swarmedon land we would say buzzed-a maze of wrasse, exquisitely colored, gracefully formed, all excited and pushing to get inside. But the fairy basses were not to be lured by such sordid bait.

In my palm I held a length of shoe thread, with the tiniest hook in the world on the end, and a nice, 


\section{CORAL JUNGLES OF SEA-COW REEF}

wine-colored worm wriggling on the hook. I held it close for fear of the parti-colored wrasse which swam about me and watched every movement. When near the coral dome I floated out the thread and let the worm descend slowly toward one of the new fisl. The fairy bass cocked up its eye, a single fan of a fin drove it closer, then it deliberately turned its back and nibbled at nothing-as far as I could see-in the water. As I was watching the basslet, a garnet wrasse rushed my hook and swallowed it, and I had great trouble hauling in and freeing it,-a fish which, in its turn, would have thrilled most fishermen and all artists with its uneartlly beauty. I backed away and my eye wandered for a moment to a clump of beautiful worm flowers. At the same instant one of my purple and gold fishlets rushed across my field of vision, and like some horrid, exaggerated shadow a small barracuda dashed after. It cut the gold half clean off, then, with a twist, seized the entire fish and vanished. Not ten seconds later the same infant barracuda took a small demoiselle near by. This settled any scruples I might have had left. I went swiftly up my rope, and soon an innocent looking white sausage of a dynamite stick was lowered close to the great cavern of millepores. We rowed off a short distance, then down went the plunger and the explosion jarred the boat as if we had rammed a rock.

I descended at once and found an immense cone of impenetrable cloud where the coral had been. 


\section{BENEATH TROPIC SEAS}

I skirted it, now and then pushing in when I caught sight of a silvery upturned belly. But these were all common parrotfish or demoiselles and I knew that I must bore straight in. It was a weird sensation to lose oneself completely in this submarine smoke and, except for less than a foot away, vision was useless in every direction. I felt and crept, peered and crawled, twice stumbling so that the water flooded my face, and several times reached far down and unmercifully scraped off skin on sharp coral when I caught a glimpse of purple, only to find it was a bit of sponge or seafan. I had scrambled along for some time and began to look for clear water on the farther side of the explosion, but the water seemed as opaque as ever. It then occurred to me that the current might be carrying the cloud with me, so I turned off at right angles. My air got rather bad, and the water rose to my mouth, and I composed several pertinent sentences to recite to my slacking pumper when I should get within speaking distance. Then I forgot my bruised limbs and my labored breathing, for there, dimly silhouetted through the murk, balanced delicately as a feather in the crotches of two broken coral twigs, rested my purple and gold little bass. I grasped at it so quickly that it shot out from between my fingers into the hopeless cloud. I feared that it had vanished forever, for beneath me was a tangle of broken branches through which I could never force my way. Sprawling quickly after it, I again saw 


\section{CORAL JUNGLES OF SEA-COW REEF}

that glorious glint and this time cupped it in both hands.

It was too thick to try for more fish and I was gasping myself like a fish on land, so I gave up and started back, suddenly to be jerked almost off my feet by the unexpected tautening of the hose. This might mean danger, so I climbed the highest crag in sight and saw that I had become completely confused in the limey fog, and, headed straight out to the open sea, had abruptly reached the end of my tether.

An hour later I returned to the scene of desolation, and found shambles of coral, all covered thickly with gray dust. As I clambered over the wreckage, extracting a fish here and there, I suddenly realized an unexpected limitation of the explosive-not a single worm was injured. Fish succumbed, but even close to the heart of the damage, great blooms of beauty raised their heads at all sorts of unexpected angles from the débris. They probably found good feeding in the coral dust. One great piece of coral weighing hundreds of pounds had been blown over on its side, and apparently from beneath the mass itself several feathery, mauve and white heads protruded. What poppies in Flanders took months to do, hundreds of these worm blossoms had accomplished in an hour.

In the course of our dynamiting, we obtained some very interesting results. On the fourth of May I let off two sticks at Sea-cow Reef and got 


\section{BENEATH TROPIC SEAS}

seventy-one fish. The fallacy of generalization was well shown by an entry in my field note-book. Looking down at the lot of fish, I wrote "the seventy odd taken today are exceedingly brilliant, most of them glowing with every color of the spectrum."

Later, I analyzed them, one by one, and found that the brilliant and the dull were about equal in numbers of individuals, thirty-seven to thirtyfour. The species showed a less even result, sixteen being decidedly bright colored and seven dull. The details were as follows,-

Brilliant

Red.........Amia

Holocentrus (3)

Blue....... Chromis (4)

Purple and

Yellow.....Gramma

Red-spotted . (4)

Yellow........Apodus

Parti-colored . Scarus (4)

Sparisoma

Hypoplectrus (4)

Thallasoma

Thallasoma (5)

Caranx (3)

Chloroscombrus

Lactophrys
Dull

Black and white . Eques

Scarus

Scarus (9)

Odontoscion (4)

Atherina

Brown......... Chromis (3)

Eupomocentrus (15)

After the first of these shots, I saw a large fish disturb the surface as it snapped at a floating victim. I went down with John Tee-Van to collect fish and to gather some pink coral I had located 
Slender Trigger-fish, Alutera

Three Aluteras Camouflaged as Blades of Thalassia Eel-grass 


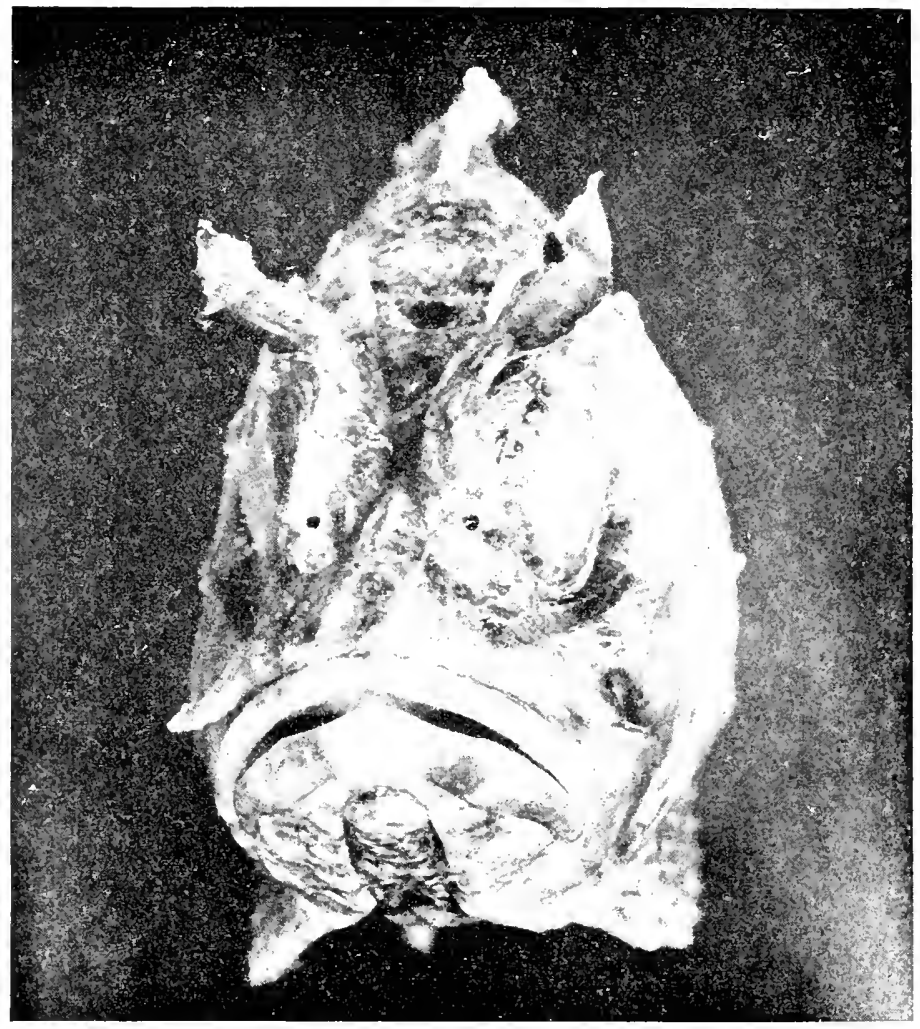

Head of Rock-fish, Scorpacna. A Common Tenant of Haitian Coral Reefs

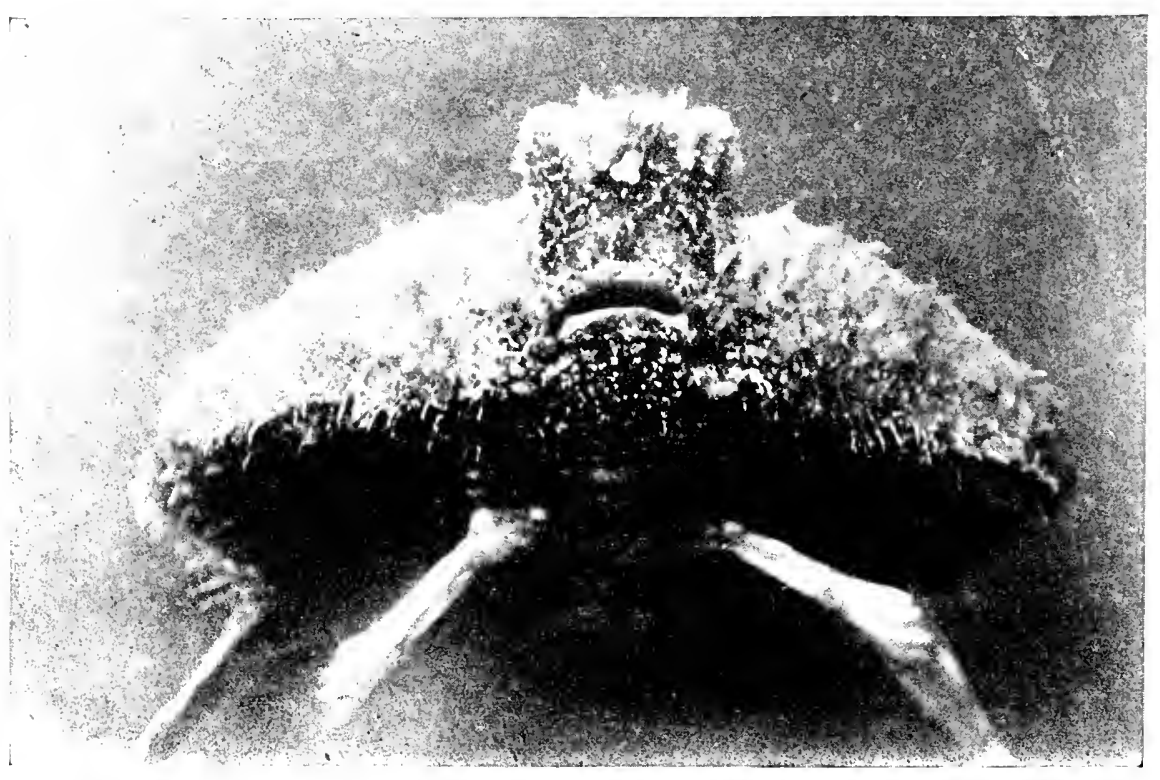

Front View of Batfish, Ogcocephalus, Showing Sensory Tentacle and Leg-like Fins 


\section{CORAL JUNGLES OF SEA-COW REEF}

behind a veil of millepores. On our way, as we clambered over some bad going, I saw a dead Eques in a deep cavern, and to reach it I had to lie as flat as my helmet permitted. As I straightened up, I saw an enormous fish just ahead-a grouper. He showed no signs of fear, and in fact came still closer to examine us. He was of a monochrome elephant's-breath color, with darker fins, deep and heavy body almost as long as ourselves, and bulging yeliow eyes. The great mouth was filled with irregular teeth, an inch or more of many being visible. From these and other characters we identified him as a large jewfish, Garrupa. He swam slowly and majestically out from the shelter of a coral crag, and, turning slowly and gently head down, almost at our feet, the great fish skilfully picked up and swallowed a dead parrot. As we watched, fascinated by the hulk of the big fellow, ready with my crowbar as I was uncertain of his mood, I saw a twelve-inch shark sucker, Echeneis, slipping over his body. It was hardly ever quiet, but kept slithering about like a skater on ice, over body, head, back almost to the tail and once even over the eyes. When the jewfish moved, the sucker took up a position on the nape and lay along the slope in front of the dorsal fin.

In the wake of the giant there followed a dozen blue-lined jacks, swimming slowly a few feet behind their great baron. When he came to rest, they gathered in a huddled group, a little distance away, like whispering courtiers in an anteroom. 


\section{BENEATH TROPIC SEAS}

Not far from this part of the reef was a small projection of the shallow shore zone, and I found I could climb up the sides of a great globe of brain coral until my face was on a level with this upper floor-the attic of the reef, so to speak. One defect of the open helmet is that it cannot be tipped very far forward without flooding, so it is impossible to assume my favorite jungle attitude of observation-a worm's eye view. But here I found I could lean comfortably outstretched with my eyes on a level with the smaller coral, gorgonias, and a scattering of Thalassia or tropical eel-grass.

One of my first observations had to do with a common triggerfish, Alutera, of which I had taken many specimens, but had no clue to the cause of its shape and color. The solution came quickly as I watched, for one of these triggerfish swam toward me, and turned head downward when he reached a small clump of eel-grass.

He took hold of a bit of coral with his sucker mouth and immediately set both vertical fins in gentle, undulatory motion, the other fins, especially the Jong caudal, being furled, so that the general body shape was tapering, which, together with the mottled green color, transformed it into a sea-weed frond or eel-grass blade. Now and then the fish revolved on its base without letting go. The trigger spine, slightly elevated, conveyed the impression of a bit of shredded tissue. An additional aid in the deception was the considerable variation of color in these fish, shifting from plain 


\section{CORAL JUNGLES OF SEA-COW REEF}

dark cedar green to a mottled greyish or greenish white.

In an aquarium on the schooner I had at one time a baby seahorse, or seapony, in the same aquarium with an Alutera, and it was an amusing tribute to the success of the regetative camouflage for the seahorse to anchor itself by curling its tail about the inverted triggerfish, much to the discomfort of the latter. The change from a healthy member of the class of fishes to a short, ragged, and somewhat mildewed bit of eel-grass was indeed rapid and convincing.

Carrying out my occupational classification of reef fishes which I began in the Galápagos, ${ }^{x}$ I found new types on these reefs. My last census is as follows,--

\begin{tabular}{|c|c|c|}
\hline FREE NOMADS & VILLAGERS & SAND CRAWLERS \\
\hline Sharks & Demoiselles & Skates \\
\hline Eagle Rays & Butterflyfish & Flounders \\
\hline Carangids & Gramma & Batfish \\
\hline \multicolumn{3}{|l|}{ Tarpon } \\
\hline Cornetfish & BALLOONISTS & \\
\hline Mackerels & Young Bumpers & \\
\hline \multicolumn{3}{|l|}{ Groupers } \\
\hline Gars & AERONAUTS & \\
\hline Barracudas & Sargasso-fish & \\
\hline Puffers & Young Triggers & \\
\hline \multirow[t]{4}{*}{ Dolphinfish } & Pipefishes & \\
\hline & Seahorses & \\
\hline & Abudefdufs & \\
\hline & Triple-tails & \\
\hline
\end{tabular}




\section{BENEATH TROPIC SEAS}

$\begin{array}{lc}\text { GRAZERS } & \text { SURFACE MOBS } \\ \text { Parrotfish } & \text { Anchovia } \\ \text { Triggers } & \text { Silversides } \\ \text { Surgeons } & \\ \text { Angelfish } & \text { FLYERS } \\ & \text { Flyingfish } \\ \text { PERCOLATERS } & \text { Halfbeaks } \\ \text { Snappers } & \text { Gurnards } \\ \text { Wrasse } & \\ & \text { SPONGE PEOPLE } \\ \text { SQUATTERs } & \text { Amias } \\ \text { Gobies } & \text { Blue-lined blennies } \\ \text { Blennies } & \text { Garmannia } \\ \text { Morays } & \\ \text { Eques } & \end{array}$

This list hints of the fascinating future of research in this under-sea field. Even after scores of descents, and the enduring of lacerations from coral, and the inevitable teeth-chattering chill which forces one up after a too-long submersion, one's observations are of the most superficial character. To the casual observer there seems nothing but terror for the small fish in schools, and, on the other hand, few or no dangers for medium or larger sized ones. These go about their business unconcernedly and with no appearance of being constantly on the lookout. The carnivorous wrasse dog one's footsteps and all but dash in between fingers when a head of coral is disturbed. The parrots paddle about, and solemnly browse, and as solemnly up-end and let the food fall down their throats. Yet an examination of stomachs 


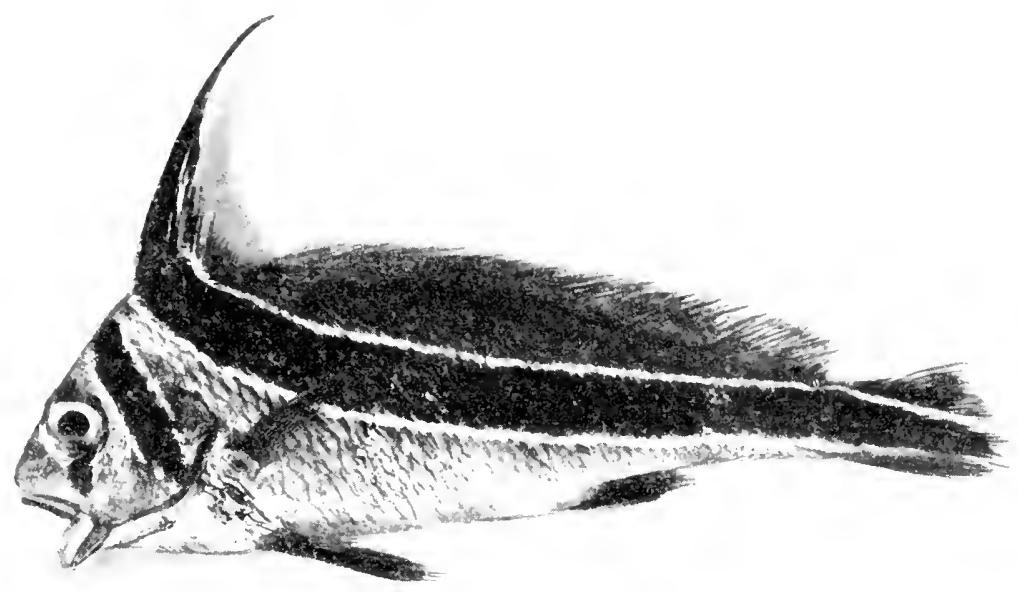

Horse-fish, Eques, which Lives in Coral Caves, and has a Most Remarkable Pattern

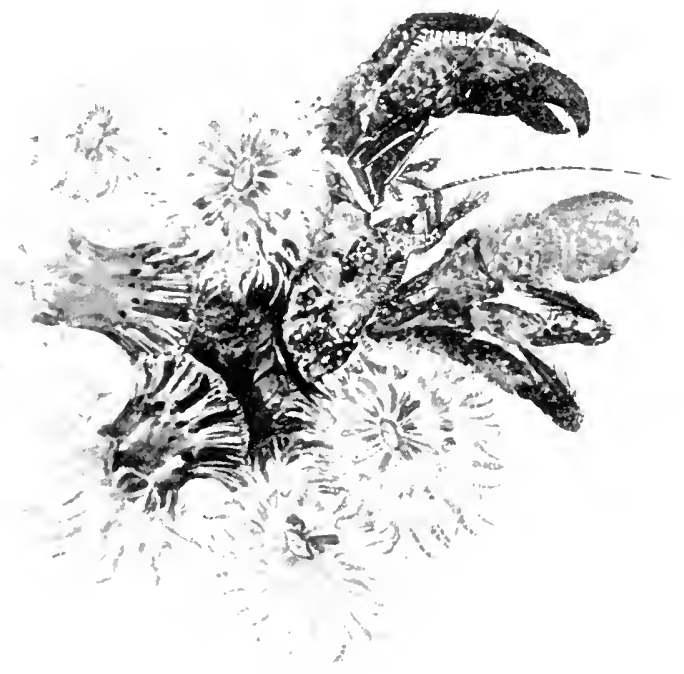

Hermit-crab, in a Living Cloak of Six Anemones 


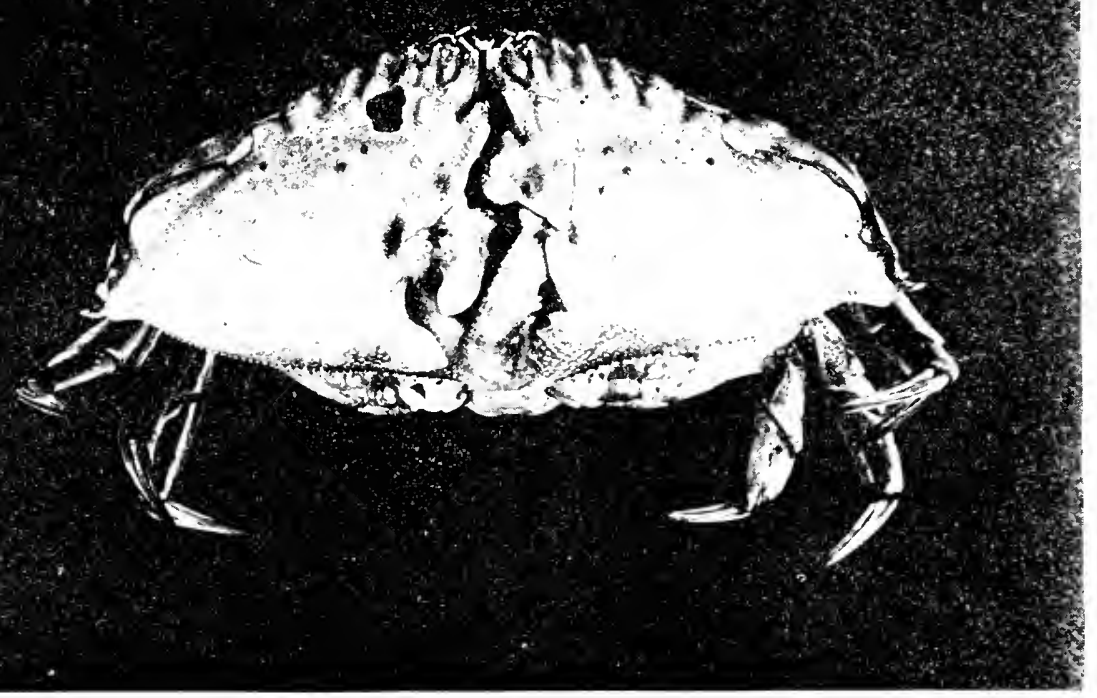

Calappa Crab, with Claws Dove-tailed Together in Front of the Body

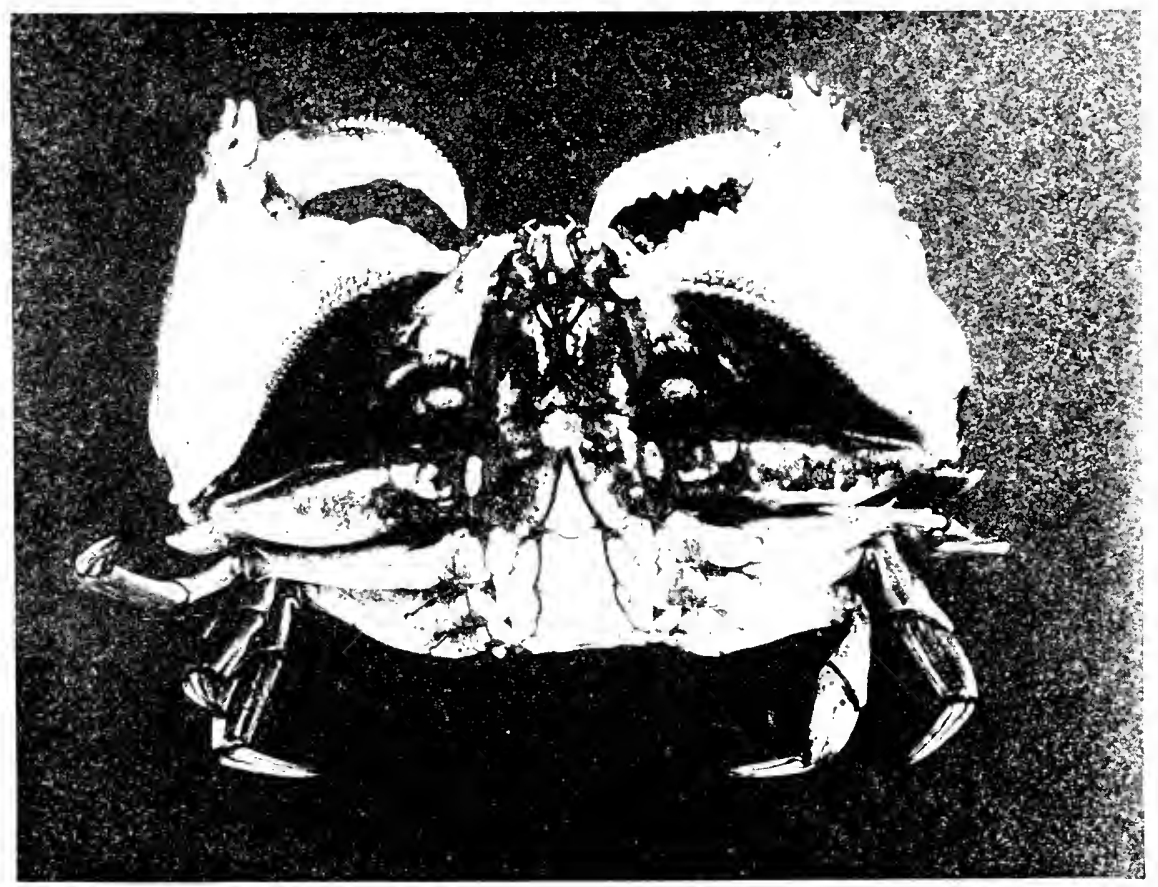

Calappa Crab, with the Claws Raised

Note their resemblance to the heads of Fowl 


\section{CORAL JUNGLES OF SEA-COW REEF}

shows tragedies unnumbered, and tells of pursuits and captures, even fish within fish within fish,the realities of which will come to our note-books only after months of watching.

One of my last days at Sea-cow Reef was rough and I made no attempt to select a favorable spot, but working the motor boat well to the eastward, I dropped anchor and slid over at a venture. It looked like a rather poor location and I was about to ascend, when I let the tide drift me some way along a narrow path of soft sand. In the distance I caught sight of an enormous wall of coral. I went back, picked up the anchor and shouldering it, towed the boat nearer. When I again went on I found a narrow gorge between two mighty coral masses, and passing through, I came to one of the most diversified and beautiful places I have ever been in under water.

The narrow gorge opened up into a large circular arena of sand, planted here and there with seaplumes, while the surrounding, lofty walls were covered with all imaginable shapes and shades of reef life, living tapestries which waved and nodded with every pulsation of the water. Large fish were abundant, a school of two-foot silver snappers appearing from some concealed cavern and milling with curiosity around and around me. Near the sand were purple surgeons and golden-lined hæmulons, both revealing their passing emotions by the ebb and flow of dark bands across the scales. I sat quietly at the entrance of a side valley and 


\section{BENEATH TROPIC SEAS}

watched the scene shift and change. Two sharks looked in from opposite sides, and a third followed my trail from the boat.

With the first were three barracudas, passing quietly, with the supercilious expression which their projecting under lips always give. Finally a procession of two hundred and six blue surgeons made a circuit of the whole arena, examining the coral walls several feet up, and most vividly recalling to my mind the waters of Galápagos. One of the barracudas was wholly eclipsed by a dense mass of jellyfish which passed in front of his suspended form. As I made my way out, I saw my old friend the six-foot tarpon just turning past the anchor rope. He had two scales missing from beneath the mid-side, and this was the ninth time I had seen him. He was apparently the only one of his kind at this reef, and, as I have already said, time after time when I dived, he would swim over, and pass slowly within ten feet.

It was a worthy farewell to Lamentin Reef, and the last look I took around before I ascended, fixed in my mind a seascape, most noble, most beautiful, and filled with unsolved problems of such compelling interest that my life overhead threatened in comparison to be drab and uneventful. 


\title{
CHAPTER XI
}

\author{
THE VERSATILE GURNARD
}

A flying gurnard, from the point of view of limb function, finds its nearest allies among bats and angels, its fins functioning distinctly as hands, feet and wings. As regards the scope of its life activities it is almost in a class by itself, for while angels and bats have conquered only two elements, a flying gurnard is at home not only in water and air but is able to trot easily about on solid earth bottom. In fact the latter mode of progression seems to be its favorite.

I have seen gurnards rise and scale away from the path of a vessel, and I have had a school of half grown ones slap against the side of a rowboat. In the young fish the fins are too short for flight, but even a two-incher will leap out and spread his diminutive, batlike wings, only to flop back at once. At best they are less skillful aviateurs than the true flying fish. This is reflected in many body characters such as wing support, the tips of the pectoral rays being simple and not multiplebranched. The head of the gurnard is encased in solid, heavy armor. To offset this excess of weight anteriorly there is a monoplane arrangement 


\section{BENEATH TROPIC SEAS}

placed far forward, the expanse of actual flight membrane being considerably greater than in the more familiar synentognathous flying fishes. Gurnards may be said to have great muzzle velocity but comparatively little trajectory or range. One of these fishes has been known to knock a sailor senseless by a head-on blow between the eyes, as the man stood at the wheel of a schooner.

A secondary use for the great wing expanse is as a float. Several times, in widely separated oceanic areas, I have seen gurnards, either singly or in a school, sunning themselves at the very surface, with the wings widely spread, floating buoyantly with only occasional flicks of the caudal fin.

I see no reason why a flying gurnard, whose pukka name is Cephalacanthus volitans, should fear any enemy or need the power of flight for anything except pursuit of food or pleasure, for it is one of the thorniest, least edible objects of the sea. The enormous opercular spines are movable laterally, carrying outward with them the gills and the exceedingly spiny maxillary. When thus spread out sideways, the fish is all but unswallowable by any enemy. To the rear of the cephalic armor and spines the body is covered with ivoryhard, razor-ridged, thorny scales, which increase posteriorly until at the base of the tail they culminate in four scales of great size. These are slightly movable and almost all keel, the bases having become contracted, and the scales twisted 


\section{THE VERSATILE GURNARD}

to form dangerous kokri-like knives, which, at a sweep of the tail, must be as effective weapons as the sheathed scalpels of the surgeon-fish.

In the Bay of Port-au-Prince, I found young gurnards coming occasionally to the submerged light at night, swimming slowly along with half spread pectorals. They allowed themselves to be caught with ease. One evening, while visiting Mr. H. H. Rogers' yacht not far from our anchorage, I won eternal fame as a fish charmer by leaning over the gangway platform and allowing a small gurnard to swim straight into my hand-my astonishment being quite as great as that of the captured fish.

When wearing a diving-helmet and sitting quietly on the bottom of a coral reef three or four fathoms down, I have seen small gurnards, individuals measuring from two to four inches in length. These swam slowly, and frequently alighted gently on a sprig of coral or on a sponge, examined it carefully, and then took off again. Specialized as these little beings are, they are no recent innovation, and from the moment when I was making notes about them on my zinc plate at the bottom of the sea, back to the time when the earliest flying gurnard flew over and walked in Eocene seas,-all this is a matter of not less than fifty million years.

In large aquariums on my schooner, I watched these fish at leisure and was astonished at their peripatetic facility. Every movement brought to 


\section{BENEATH TROPIC SEAS}

mind a strange, half-]iving airplane. A gurnard volplanes swiftly downward from the surface, wings tightly folded, and when close to the bottom turns slightly upward, partly spreads its pectorals and, stretching out the long, thin ventral fins, alights gently, and at once trots off, scampering here and there, now and then actually holding up one leg-fin, as the fish pivots slightly and looks about. When it walks forward rapidly the body is kept almost horizontal, with the tail clear, but when it slows down and begins taxiing across the floor of the aquarium, the caudal fin drops and the lower rays drag, like the tail stick of an airplane. The ventral, leglike fins work alternately, one after the other, and each step is effective, sometimes directly ahead, or again to one side or backward. These fins are remarkably long, the fish standing very high; when in action they are constricted, appearing slender and perfectly straight, only the very tips of the rays bending back and functioning as feet. Every now and then the anterior free portions of the pectorals stretch out and down, fumbling about as though searching for something.

In front of the first dorsal fin are two free rays, long, slender, and knobby at the tips, and for their entire length quite separate from the rest. Except at their very base these two anterior rays have lost all fore-and-aft alignment, and by a most ingenious asymmetrical arrangement appear to lie completely side by side. They fit in a groove 


\section{THE VERSATILE GURNARD}

alongside the four spines of the first dorsal fin. When the fish begins walking, these two rays separate laterally and act as balancers, one on each side, forming an angle of about forty-five degrees. If the gurnard turns quickly or trips up, one of the two rays dips down on the corrective side, exactly as a person's outstretched arms assist in regaining lost balance. The motion pictures which we were able to secure of the walking gurnard show all of these unpiscine refinements.

When Professor Moseley went on the classic Challenger expedition, he took his trout rod with him, and in the Cape Verde Islands he found flying "gurnats," as he called them, abundant. He writes:

"I hooked one, however, near the surface, when fishing with a rod and tackle for small mackerel and silver fish. This was quite a novel experience in fishing. The flying fish darted about like a trout and then took a good long fly in the air, and in an instant was down in the water again and out again into the air, and being beyond my skill in playing with such light tackle, soon shook itself loose and got free."

As I dived day after day, and walked about the coral reefs of Haiti, I was ever more deeply impressed with the astonishing uses to which the fins of fish are put. I saw a dozen or more species which actually, and not as a mere figure of speech, deserve the term walking, while in as many more I watched the pectoral fins being used to turn 


\section{BENEATH TROPIC SEAS}

over bits of coral or to fan loose strands of seaweed away from some edible morsel. Even in this first season's brief study of reef life I saw the occupation and sturdy defense of definite homes, I noted curious sleeping postures and quarters, and extremes of emotion which were reflected not only in bodily actions and in the motives of the fish, but in the instantaneous shift of individual pattern and color beyond anything which I have ever considered possible.

All this serves to bring closer together the lives of the lowly vertebrates and those of our more familiar terrestrial two- and four-footed fellow creatures, who share with us today this little whirling ball of earth and water. 


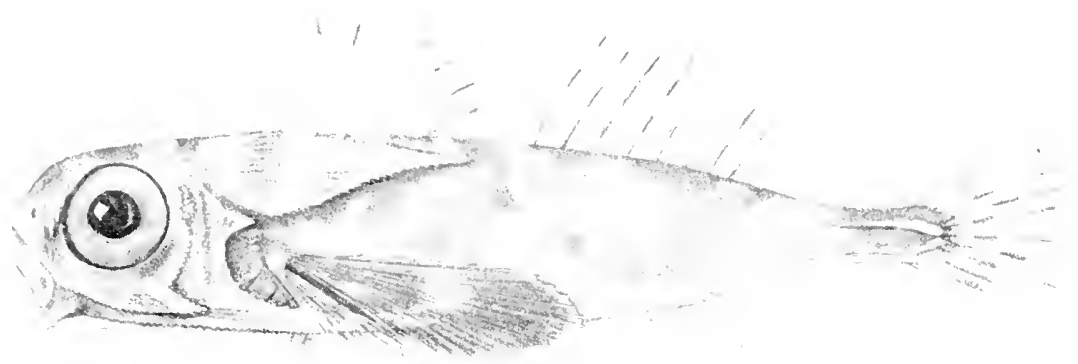

Young Flying Gurnard, Cephalacanthus volitans, taken at Light, Showing the Ventral Fins Functioning as Legs

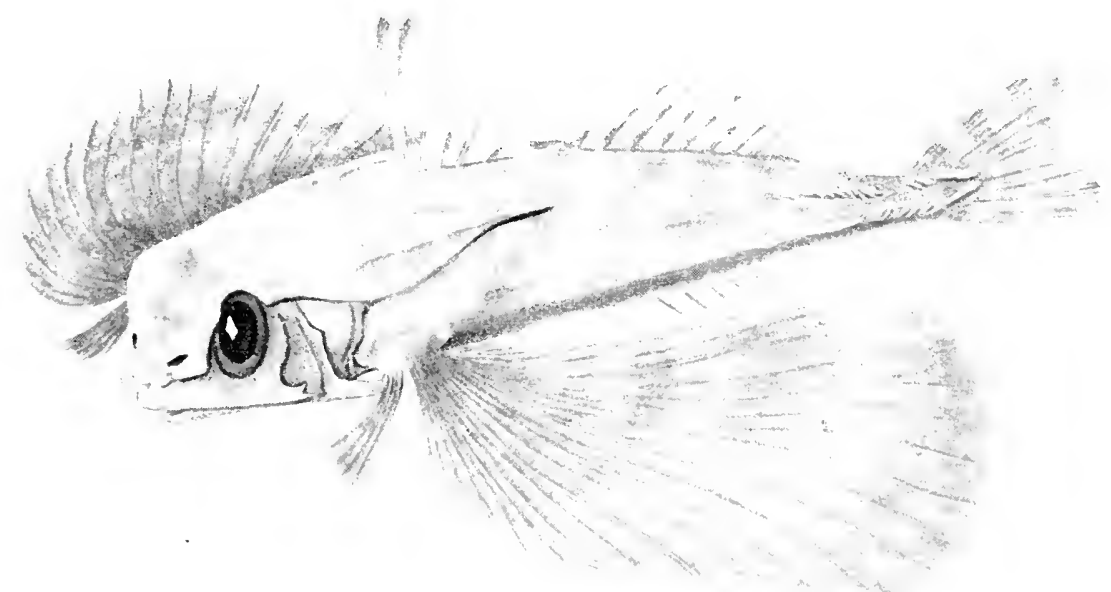

Flying Gurnard, Showing the Pectoral Fins Divided into Two Parts, the Anterior Portion used as Hands, the Posterior as Wings 


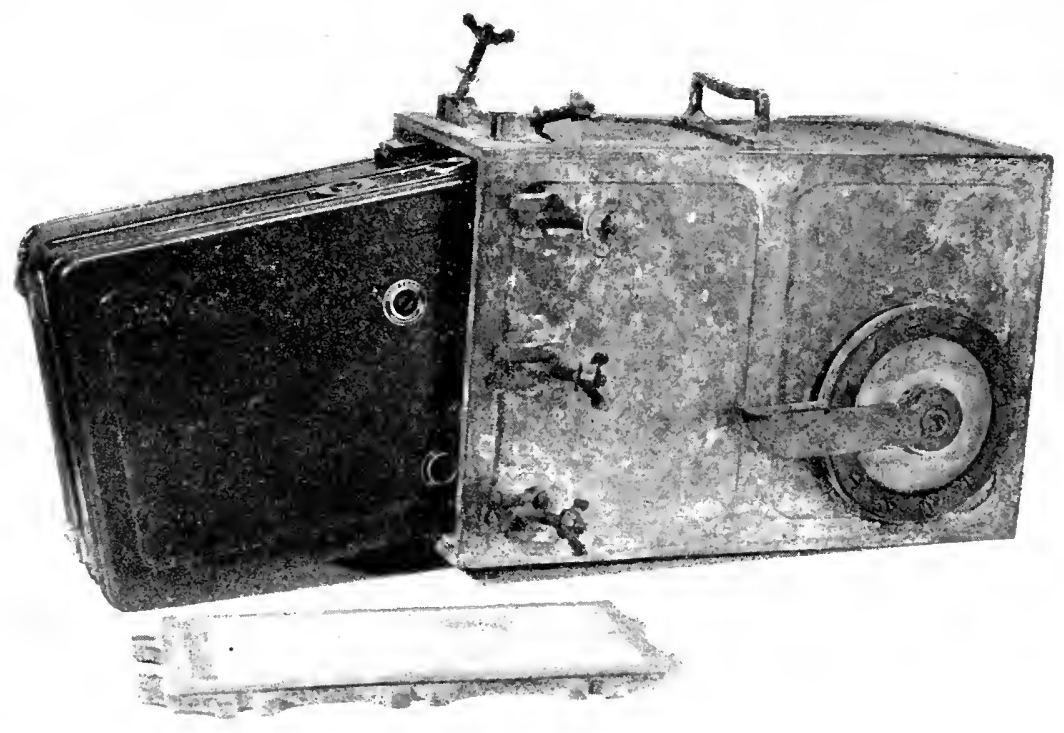

Brass Submarine Camera Box Open, Showing Camera

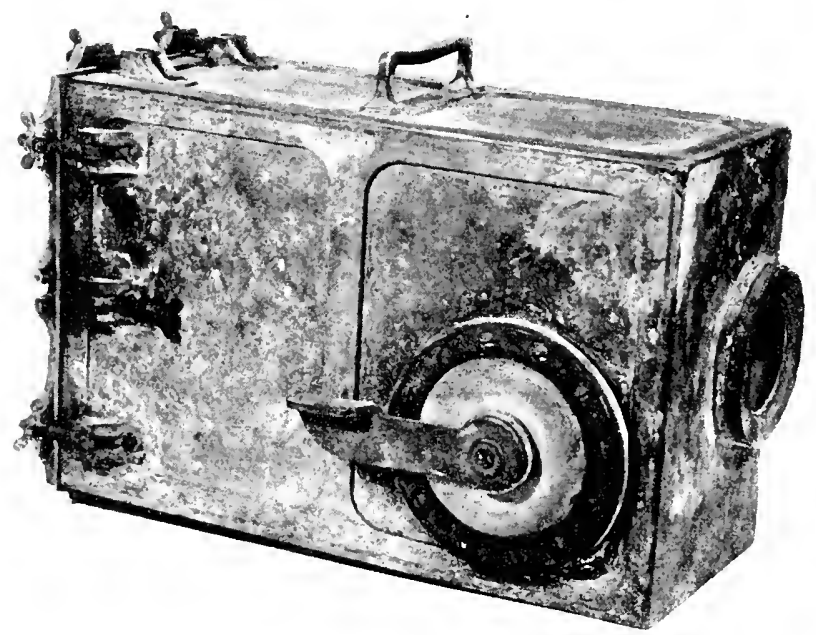

Submarine Camera Box Closed, Ready for Submersion 


\section{CHAPTER XII}

\section{HUMMINGBIRDS}

No one should quite believe in hummingbirds until he has seen one. Only recently have I become convinced of active volcanos and the home life of coral reefs, but I am still skeptical as to the rings of Saturn and not wholly persuaded that mammoths are to be found frozen in the ice of glaciers. While I have a passionate interest in these, so far, unseen things, yet by leavening this with a small secret doubt, I keep at fever heat the desire to see them for myself-making of such personal contact a future necessity.

It is, I find, eminently satisfying to cultivate an opinion of equal confidence in fairies and in Eskimos-thus insuring perpetual interest in Pook's Hill, Greenland and Mluna. Many people who scoff at such a credo, voice their unconscious allegiance in exclamations such as "It is too wonderful to believe!"-which is only what I am trying to say of a hummingbird.

You and I are very wonderful beings, yet we (or at least you) would be complete failures if featured in a side show of a circus. We should have to be terribly stout, or frightfully emaciated, or inconceivably dwarfed to be allowed to sit 


\section{BENEATH TROPIC SEAS}

before the public and sell our photographs and, now and then, amble slowly in procession around the velvety tan bark. Hummingbirds, merely as birds, do not exert as strong an attraction on our mind as when we think of them as the smallest of birds. But this is not enough. If we are to get the utmost out of a half hour's consideration of these marvellous little beings, we must visualize them from all sorts of unexpected angles. I for one am mighty glad to be living on the earth at the same time with them. It is more important to me to be able to see a hummingbird next year than to cross the ocean in two days instead of six. The present epoch might well be called the age of man and hummingbirds, for both are at the maximum of their evolution. What the latter lack in actual size they make up in number of species, for there are full five hundred different kinds. If we allow only ten hummingbirds to a square mile throughout even a small portion of their range, there must. be living with us today at least fifty millions.

If I am to fill my tale with superlatives, let me register at once a super-superlative-amazement at their vitality. A hummingbird's life is one burst of enthusiasm - not an unreasoning round of sleepless labor like the life of an ant, but an existence guided by intelligence and individual adaptation worthy of the class of beings to which it belongs. John the Baptist found all the necessary vitamins in a diet of orthoptera and the stored-up provender of other insects, but no greater miracle has ever 


\section{HUMMINGBIRDS}

been wrought than the alchemy which can translate spiders and wild nectar into a living atom of a feathered dynamo, hurl it hither and yon through hundreds of days and thousands of miles, and endow it with a frenzy of courtship and a depth of passion sufficient to woo and win an unwilling female ostrich, instead of merely a susceptible, thimble-sized mate.

Picture, if you please, a "comfortable, clucking hen," walking toward us, with an ostrich on one side and a hummingbird on the other. This is improbable, but helpful. If we liken them to men of corresponding height and weight, the human trio would then present on the one side a giant twenty-seven feet tall, weighing eleven tons, and on the other a midget of nine inches, weighing in at two ounces.

The smallest bird in the world is Calypso's Cuban Hummingbird, a mite whose length from beak to tail-tip is barely two inches. Ulysses would have had more chances of perpetual happiness and youth if he had devoted to the study of ornithology the seven years of feeble resistance to the blandishments of this original nymph. Still there were compensations which leave this a moot question. Calypso's hummingbird weighs, all told, a matter of something less than a gram, which, stated more intelligibly, means that thirty or forty of him could be sent for two-cents letter postage.

One day as I was rowing lazily over a coral reef close to the sand beach of Bizoton, I heard a 


\section{BENEATH TROPIC SEAS}

sharp whirr of wings directly behind me, and a moment later a ruby-throated hummingbird alighted on the end of a long net handle which stuck up over the stern-post. I rested on my oars and watched for a full minute while the perfect plumaged mite preened and arranged some feathers too small for my coarse eyesight. This was not any of the Haitian hummers, some of which were larger and one much smaller, but my own familiar countryman of northern honeysuckles. When he had finished his toilet, he wiped his beak, rose gently, hung in front of my face for a moment, and then, with a single upward curve, set a course northward, directly across the wide expanse of water.

Early this year-as in the past for who can say how many hundreds of centuries - a strange restlessness will seize upon a host of these rubythroated hummingbirds scattered over mountains and jungle from Panama and Costa Rica northward throughout Mexico and in the Bahamas, Cuba and here in Haiti. Feeding from the same blossoms are larger and smaller hummingbirds, some with sickle bills, others with long, waving tail plumes. To these, February brings no special message. But thousands upon thousands of rubythroats become gradually magnetized with the northward pulling of ancestral habit. No change in temperature or food impels them-the impulse comes from within. Day by day they drift along, borne on this impalpable wind of racial memory, 


\section{HUMMINGBIRDS}

until it becomes a hurricane of instinct too strong to resist and they are up and away-a great army of loumming immigrants, forging northward, through tropic latitudes, on to even the Arctic zone.

All this we know with a sort of vague certainty, as a composite of hundreds of records of birds seen and collected, but at best we can only faintly imagine the marvel of millions of living motes, sleeping each night upon millions of twigs, with millions of heads under millions of wings. Each morning the awakening-millions of sips of dew, followed by the capture of tens of millions of spiders who had thought that day to spin or leap or do whatever spiders would, before their paths crossed those of migrant hummingbirds.

No person of real worth ever forgets the first hummingbird he has ever seen, and if his fate has cast him in cities or deep in mines or other doleful hummerless places, then a certain cell in his brain should always hold the thought of hopes for hummingbirds.

Soon after landing, our New England ancestors found leisure for things other than Indians, furniture and religion, and as early as 1634, William Wood writes, "The Humbird is one of the wonders of the Countrey, being no bigger than a Hornet, yet hath all the dimensions of a Bird, as bill and wings, with quills, spider-like legges, small clawes: For color, she is as glorious as the Rainbow; as she flies, she makes a little humming noise like a 


\section{BENEATH TROPIC SEAS}

Humble bee: wherefore she is called the Humbird." As far back as 1697 Benjamin Buttivant kept one of these birds in captivity in Boston, and tells us, "The Humbird I have shot with sand, and had one some weeks in my keeping. I put a Straw for Perch into a Venice Glass Tumbler, ty'd over the Mouth with a Paper in which I cut holes for the Bird's Bill (about as long and as small as a Taylor's needle), and laying the Glass on one side, set a Drachm of honey by it, which it soon scented; and with its long Tongue put forth beyond its bill, fed daily; it muted the Honey pure, and was a prospect to many comers: it flew away at last."

If we walk through a northern garden this spring we may find the two hundred and thirtieth generation grandchild of Benjamin's humbird-first as a distant, indistinct murmur, rising immediately into an assured, definite hum, and before our face, resting easily in mid-air, is the wingless wonder of a ruby-throated hummingbird in flight. His head, his back are shining green, his breast and under parts dull dusky brown, but his throat is living color. At first sight it is coal black. Then as his bright, intelligent eyes examine us closely, he turns on his own axis, and the dull coal kindles and takes fire - a greenish flame which flickers into golden and this to brilliant, blazing, metallic red.

Nothing is easier than to wax sentimental over the slaying of a hummingbird. Results only will serve to justify it, and it is undeniable that for many reasons, a hummingbird in the hand is, 


\section{HUMMINGBIRDS}

intellectually speaking, worth many hovering on the wing. We learn, for instance, that all is not pigment that glitters, and that the glorious, rubygold gorget makes "a bit of flying rainbow" a scientific truism. A throat feather held up to the light is plain dull gray, but when the sun plays obliquely upon its surface it dazzles the eye. The dull feather is the background of cloud, the surface prism lines are drops of rain; the result in each case-storm or feather-is a rainbow. The tiny wing feathers are too useful to share the luxury of ornamentation; their mission is to beat upon the air, to throb so skilfully, leaning upon it with an exquisitely exact pressure of two grams, that a corresponding weight of flesh, bones and feathers is held aloft and stationary. When at rest the wings are folded away out of sight, when in use they vanish into an intangible blur.

The way of a hummingbird's wing in the air will end our anatomy, but the marvel of it is like a vista into an unknown country. The exact physiology and the mechanical formulæ are to be searched for in technical books, but the manner, the superficial why of it is very literally within arm's reach. Try-and fail most dismally-to wave your arms up and down fast enough to become a blur. Then attempt-and succeed-in shaking your hands to the vanishing point. Our upper arm, from elbow to shoulder is relatively long, our wrist bones exceedingly short, and on plucking a hummingbird's wing we find the upper 


\section{BENEATH TROPIC SEAS}

arm reduced to a wrist-like proportion. "And so, Best Beloved," we now know why an albatross can not hover, or a hummingbird soar.

The sight of the bare angular little arm reminds us that the hummingbird, although insective in size, is wholly bird. Even Everyman's eyes can detect the three remaining fingers, and a reading glass will probably show a claw. Indeed, if I were to select the type of life which, in character, most resembles these birds, I should choose the small, green lizards of the south. Their bright eyes, their fearlessness and the inconceivable speed they can attain are all hummingbird-like. This is not wholly fanciful, for the "spider-like legges", of the diminutive birds are clad in scales, persistent memories through all ages of some lizardy ancestor.

Due principally to their speed and small size, hummingbirds live in a world apart, a lilliputian dimension of their own. The garden ruby-throat hovers before us, a very definite bird within reach -an instant later he has vanished into thin air. But there is a way of outwitting him, an art which cuts straight through his defenses and brings him and all his life under observation. We look for the first of his kind in New York latitudes in early May, but long before this we must prepare the snares, the traps of sight and odor, which will tempt nim from his path. Plant and plant and plant his favorite flowers; bee-balm, petunias, bouncing-bet, trumpet-vine, nasturtiums, sweet peas, honey- 


\section{HUMMINGBIRDS}

suckle, tuberose, columbine and delphinium. Best of all is a background of horse chestnut and apple trees. Such a barrage of color and scent will certainly attain its object, and one of the first hummingbirds you see will probably not be a hummingbird at all. The closest examination will only add to the wonder of the sphinx moth which comes hovering in late afternoon, with coiled tongue masquerading as a beak, and an astonishing band of long hair functioning as tail. But there is no hum of wings, and the eyes are not intelligent and have to be helped out by antennæ.

This similarity on the wing between moth and bird is amazing, but the likeness ends there. W. H. Hudson was woefully wrong when he devoted an entire chapter to insectizing the hummingbird. We will stop to demolish only one false premise - the trait of fearlessness common to both groups. This may be due to several fundamental causes. In the Galápagos the birds and reptiles have no enemies, therefore no fears, and the appearance of a human being inspires no timidity. Insects and the hummingbirds about us have been familiar with man for generations and count him among the least of hostile beings. The hummingbirds of the deep tropical jungles, however, are exceedingly wary, for there any trust in creatures with hands fashioned like the quick-sensed monkeys would be fatal.

The female hummingbirds arrive soon after the 


\section{BENEATH TROPIC SEAS}

males. They discount his metallic green back by also possessing it, but the throat ruby is his alone. If we watch them day by day, the fears and hopes and achievements of these delightful little beings will, by discovery, become our own. We may see them bathe, either in the midst of a small waterfall, or actually wading into a pool whose depth can be sounded only by millimeters.

The first characteristic which we note is pugnacity. Hummingbirds drive moths, wasps, other hummingbirds and birds of larger size from their favorite flower beds. They have been seen actually to attack and put to flight crows, flycatchers and hawks, and their civil wars rage so fiercely that two birds will sometimes fall headlong to the ground, each gripping the other's bill. As to actual enemies, giant bees resent their impudence and will attack and repulse them, although no one has ever witnessed a casualty in these fairytale encounters. The elements are probably their worst hazard, with such lesser pitfalls as barbs of thistles, upon which I have found a hummingbird impaled.

While a female differs from the male chiefly in the plain greyish white of her throat, yet psychically she is his antithesis. If a season's emotional activity of the twain were diagrammed, that of the male would run along rather low and evenly, except for a brief period indicated by a tremendous peak in the graph-the abrupt, explosive rise of the fever of courtship. That of the female carries 


\section{HUMMINGBIRDS}

steadily on, always on a higher balanced line, showing no great rise or fall.

With squealing chirps and almost clicking song, with darts on high, and swooping rush of whistling wings, the male ruby-throat woos and wins. The female perches near, with no keen appraising eye or coy pretense, but, what is no less romantic, a sublime relaxing to the effects of pattern, color, sound and movement, until she accepts this blazing acrobat as mate.

The nest is begun at once, and the eggs deposited often while it is yet a mere saucer of yellow down. With the laying of the second egg-an oblong, alabaster pea-the male is banished. Our human judgment cries shame at the apparent unfairness - the male's part a summer's holiday of courtship and a moment's mating, and all responsibility for the continuance of the race of hummingbirds slips from him. The rest, for him, is solitary flights and feeding, and at the first crisp day of mid-October, to whir back to the tropics again.

The female has to watch and approve his useless antics, to accept him and dismiss him; then put her whole little soul into the gathering of down from fern and tree, and reel up yard upon yard of stout cobweb cable, with which to bind it fast to a twig or leaf. For spiders are to hummingbirds as coco-palms to savage islands-food and wherewithal for shelter. It is not sufficient that the nest be thick and firm, and fast bound to the twig, but it must be safe from every prying eye. 


\section{BENEATH TROPIC SEAS}

So, with all the other labor, she must find and tear off lichens,--a dozen, twenty, each to her as large as a barrel head to us, and with straps and bands of cobweb, glue them fast to the outside of the nest. And when we thus have noted the great need implied in this additional work, we recall that in California, the black-chinned hummingbird--blood sister to the ruby-throat-thrives and multiplies in nests, which, lichenless, appear like tiny yellow sponges on the tree. We cross out then our newfound law, confess our ignorance, and marvel all the more.

From the gathering of the first bit of down to the flight of the second nestling occupies about five weeks. The beautiful symmetry of the two pearly eggs is destroyed about the fourteenth day, when they are replaced by a pair of changelingstwo helpless blobs, two black and shriveled things which might well be awful maggots, horrors to be pitched out, twin Calabans come to curse the gentle mother for some dreadful pre-natal crime. She accepts the two awful beings for what they are, although if we watch closely, we see one day what appears to be crime compounded upon crime. She returns to the nest like a shooting spark from a rocket, and alights on the rim with the impact of a drifting thistledown. Before we realize her intention she raises her sword-like bill on high. At the same instant, both of the pulsating lumps stretch upward-perhaps a plea for mercy, begging at least for the boon of life. The 


\section{HUMMINGBIRDS}

crime-ridden parent can stand her awful offspring no longer, and with a single, skillful sweep, she inverts the needle-beak and stabs the ebon creature through and through. Down and down go her mandibles, into the very heart, if indeed it have a heart, and,-behold, we have seen a loving mother hummingbird give her nestling a full meal of predigested spiders! The second is fed, the sabre withdrawn and wiped clean, and three tiny birds are happy - two from the bliss of material satiety, the third from the sense of duty perfectly performed.

After a few days the leaden skin cracks open, and we catch a glint of light upon a new-born eye; a hedge of stiff thorns blossoms into sprays of downy feathers, a bulge becomes a beak, and the nest grows far too small to hold the spidernourished twins. The feathers of the wing and tail appear, even a glint of shining green, and now one climbs upon the sunken rim and tries his wings. They work so well he has to cling right tightly to the cobwebbed down to keep himself from being carried off. Next day, when instinct bids him go, he lifts and hovers, flies upward to a twig, looks about, and calls the world his own.

We wonder what niche in life, what characters evolved through time, have made possible the wonderful success of the family of hummingbirds. Here are tiny creatures, brilliant metallic colors, great vitality and activity, with long beaks and tongues, a powerful hovering flight, and head- 


\section{BENEATH TROPIC SEAS}

quarters in the tropics. One or all of these qualities must have reduced competition with enemies to a minimum.

If we go to the tropics of Africa and India we find the hummingbirds' niche partly filled. High up in the Himalayas I have more than once been startled at seeing apparently a hummingbird dart past toward a mass of rhododendron blossoms. It always proved to be a tiny sunbird, glowing in the richest of iridescent hues, and seeking insects and nectar in the heart of flowers. They have never learned to hover, however, but cling to stalks and reach as far as they can for their food. The resemblance in size and color is merely accidental, for sunbirds are not at all related either to swifts or hummingbirds.

We have no clue whatever as to ancestry. No fossil hummingbird has ever been found. Of the billions which have lived and hummed and died through all the ages, not one has ever been embalmed in mud or sand-thistledowns are not to be looked for in the heart of boulders.

Seventy years gone, Thoreau made this note in his journal: "Its hum was heard afar at first, like that of a large bee, bringing a larger summer. This sight and sound would make me think I was in the tropics-in Demerara or Maracaibo."

Thoreau never had the good fortune to visit Demerara, but I longed for him once when I had an astonishing experience in the jungle of that very Colony. On the twenty-sixth of a November I 


\section{HUMMINGBIRDS}

was hurrying toward my Kartabo laboratory to escape an impending storm, when I was suddenly halted by a sharp squeak at my very elbow. I froze into a semblance of a khaki tree-trunk and for fifteen minutes forgot to move or breathe.

In the path of the squall there materialized in mid-air a Rufus Hermit. (Now that the succeeding fifteen minutes are speeding into past time, and I am sitting quietly thinking over this unbelievable experience, I parenthesize the necessary information that this Guianan hummingbird is Phothornis ruber episcopus Gould. This name, as you see, occupies two inches of type, whereas his whole length from beak to tail-tip is only an inch longer.)

The feathered atom hung motionless before me for a few seconds, then sank to a twig near the ground about six feet away. Instantly a second hummingbird appeared, of brighter hue, apparently a male, and the courtship began. It was divided into three distinct phases, each of which seemed a climax in itself-each more astounding than the preceding.

For a few moments the newcomer hung suspended, turning very slowly in all directions, while I relaxed into a position which I could hold without danger of sudden movement. The hermit then sank gently and as steadily as if lowered by the guiding thread of some unseen manipulator of marionettes. Faced towards the perching female, but about a foot in front and above her, he began 


\section{BENEATH TROPIC SEAS}

his dance of life. He seemed to be on an invisible tight-rope, such as Rackham would have strung of cobwebs for fairies. In fact I peered over a leaf to persuade myself that he was not actually balancing on some slender, horizontal twig. Throughout the next ten minutes he did not vary a half inch up or down, along a line about a foot in length.

The dance began with a rhythmical twisting from side to side, his head always facing the object of his devotion, an apparent limbering up of his small being. With the fourth or fifth twist, his whole attitude changed. While the haze of wings kept its position, his body rose slowly into a nearly erect posture; his long, curved bill was slightly raised and the conspicuously pale wire of a tongue thrust far out, continuing the curve of the mandibles and almost doubling their apparent length. The tail gradually lifted until it was almost upright, feathers widely spread, peacock fashion. The tiny legs were at the same time slowly stretched downward to their full length, and the band of white down on each puffed out. Between them, the fluffy under tail-coverts had separated completely from the upraised tail feathers, and joined with the leg ruffs to form a solid fluffy-white band across this aerial vision.

So steady did this bird keep that every featherlet on its body was visible. The wings were a faint grey blur and gave forth a hum which rose slightly at each turn. The air which these living pro- 


\section{HUMMINGBIRDS}

pellers disturbed produced two curious effects; all the leaves for several feet beneath the little bird were in violent agitation throughout the performance, fern fronds trembling and scarlet-spotted caladium leaves swaying, while all around me the jungle foliage was motionless. I was surprised to see that the bright rufus color of the under parts of the bird was confined to the throat and breast, forming a small, warm patch of rich pigment. Below this the plumage appeared dark gray, with a confused, blurred effect. Careful scrutiny revealed that the wind from the wings was so agitating the feathers of the lower breast and remaining under parts that all the rufus surface was lost. Only the dull hue of the feather bases was visible, while the fluttering feathers themselves added to the strangeness of it all.

Ever since the shift to an upright position, the lateral pendulum swing had never ceased. The bird swung slowly sideways through the twelveinch arc, gaining speed when approaching each end, then stopping abruptly with a rise in the hum and a sudden surprising jerk, as if it had brought up against some invisible barrier. The head and body were immovable, but the tail fan shifted so that it faced always toward the female.

When this had continued for at least five minutes, the audience rose steadily from her perch, approached and faced her suitor, and he ceased his swinging while they hovered motionless a few inches apart. She darted back and instantly the 


\section{BENEATH TROPIC SEAS}

second phase of the display began. This was an acceleration of the same swinging dance, but with vocal accompaniment. Five or six humming turns were made, and then, with only a momentary withdrawal of the tongue, a high insect-like trill of surpassing sweetness arose. It came in short, separate cadences, controlled, like the humming, by the jerky ending of the side swings, the tone rising abruptly three notes at each lateral node.

For a time this continued, then it increased. The swings, while they occupied the same space, became more rapid, gradually gaining speed until the sequence of trill actually joined, and the bird became a rocketing, swiveling wonder, always, however, level and perfectly steady.

For the second time the female rose and approached. They faced one another for a brief moment, and again she alighted. Without an instant's hesitation the frenzied male shifted into the third and last scene-the climax of climaxes. Still confined by the unseen bond to the narrow line, the foot of space, he began a maddened flinging about of the whole body. I can describe it only by imagining the bird held by the beak and thrashed from side to side. The tongue was withdrawn, the song died away, the tail simply thrashed about after the body, and the reckless rhythm was punctuated by a deep, bee-like droning; sonorous, and wholly unlike any bird sound I have ever heard. I fully expected to see the hummingbird fall headlong any moment, its wing and neck 


\section{HUMMINGBIRDS}

broken, its plumage irrevocably disheveled. It had ceased to be a recognizable bird, it had become a blur of unthinkable vitality-a visible dissolution of minute jungle life.

I watched it, almost hypnotized, and was about to reach out and touch it to see if my eyes were actually recording a real phenomenon, when the droning seemed to gather volume and force-and a huge raindrop splashed on my forehead. The courtship song of one of the smallest of birds was continued and carried up to the heavens in the first roll of thunder of the onrushing storm. Close over the trees the clouds were billowing swiftly past, while about me the only breath of movement was from the infant whirlwind of the hummingbird's wings.

With the dying rumble of the first thunder the female left her perch for the third and last time, and now the two birds, close together, beak to toe, rose steadily up; the last I saw of them, a glimpse through the highest branches, as they caught the force of the first blast, and drifted, so close together that they seemed a single mote, toward the heart of the jungle. 


\section{CHAPTER XIII}

\section{THE NEW STUDY OF BIRDS}

A day seldom passes when the long arm of coincidence does not wave gently over my head. At dawn one day in early April when I emerged from my schooner tent I knew that I had one of my rare reactions from work. I had dived too often, I had glued my eyes to the microscope long after my body had begged off,-in a word, I had gone stale on submarine science. So I rowed me ashore alone and curled up in my favorite, half-rotten old boat, discarded long years ago and beached forever in a sugar-cane field. And here my eyes and ears and mind turned to birds, but even now I resented any approach to direct facts, and my mood exuded the following observation:

"I know several people, not otherwise criminally insane, who dislike and are terrified by birds," and so on in the same vein. By such vitriolic effusions I purged my mind, and after lunch I motored to the American Club and sought to rid my body of scientific excesses. On the tennis courts I paired with Lieutenant Halla, and we had as enemies General Russell and Commander Wood - my particular trio of gods in my Haitian Valhalla of kindly hosts. It was hot even for Port-au. 


\section{THE NEW STUDY OF BIRDS}

Prince, no one wished to lose a game, so Wood and I never ceased to stab short, smashing volleys at each other within racket's reach of the net. After the fourth glorious, gruelling set I knew that the temperamental evil had left my physical me, and that on the morrow a fish would be as new and wonderful a thing as ever, and my next dive would again be into sheer fairyland.

While the last fraction of stabilization was being effected by the tallest high-ball in the world, I was presented to an imposing and charming matron-a passing tourist of note- who said she hoped to be invited to visit the schooner, but not if there was a single live bird on board, as she could not bear them. She then shuddered as a little ground dove flew past. My mind went back to what I had written in the morning, and on the spot I invented and described in detail a noisy and well filled aviary on the Lieutenant, and after making my manners, turned for absolution to my interrupted occupation. And now, without further preamble, I can elaborate and complete my theme.

I know several people, not otherwise criminally insane, who dislike and are terrified by birds. In some future life their unspeakable parents or nurses will doubtless have their souls recleansed as angle-worms. And even in that incarnation their ultimate fate will probably be ejection from some grassy crevice by some holy angle-worm into the maw of a waiting robin. Let us think of this class of fellow humans as thankfully small and 


\section{BENEATH TROPIC SEAS}

insipid - the ornithological one-half of one per cent.

Then comes the great majority of mankindlet us say ninety-four and a half per cent-for whom birds occupy an optical fourth dimension, or who can visualize them only between gunsights. A very charming and cultured young lady, in answer to a question about birds, writes from Canada, "There are small black birds here which must be crows, and others are gulls, or at least they keep near the water." Toward all these we must feel only pity, for there is worthy ornithological material hidden beneath the crass ignorance of some, and many a man who boasts of his right and left at pheasants is also thrilled by the song of a nightingale or veery. Who am I indeed to cast the first stone when I have shot a dove on its eggs in the name of science, and shall probably do so again. But in a separate class is the man whose idea of sport is shooting at live pigeons sprung from traps. I would anticipate any postmortem orientation on his part with a forceful wireless prayer: Send the soul of this man back to earth in the bodies of all the old horses of future bull fights.

Now that we have disposed of the useless and unhappy nineteen-twentieths of our fellow mortals, we have only to consider that remaining five per cent of us whose lives on earth are brightened by a conscious awareness of bird life, whether it be casual interest or consuming enthusiasm. A few of us are congenital fundamentalists in that, from birth, birds seem to dominate our interests. I can 


\section{THE NEW STUDY OF BIRDS}

well remember the time when, on cold wintry mornings, an alarm clock and my mother's impatient voice were but silence compared with the caw of a passing crow. And many a deciding overhead volley in tennis have I lost by the inopportune swooping past of a swift or swallow. But the only use of these maudlin reminiscences is indication of approaching old age.

Today, here, in the midst of our so-called civilization, more than five thousand months after Columbus landed, what can we do with the birds about us that every Isn't-nature-wonderful person is not doing? Bird books and keys we must have for we must know their names. But what then? The instinctive thing is a list of birds of some locality, but except in the uttermost parts of the earth, this has been already done again and again. The last number of the $A u k$, the official bird magazine of our country, had a third of its articles and about one-half of the pages devoted to such lists,-lists of the uttermost importance, but of far distant localities. So there is little excitement in an ordinary enumeration of the birds of your suburban vicinity.

But now comes the fun. Bring to bear all your Holmes-Lupin-Cleek imagination and devise some unusual method of observation. I once had a week in a Brazilian jungle, where indiscriminate shooting and listing would have yielded little of value. So I spent all possible time in a canvas steamer chair at the foot of a berry tree and in a remarkably 


\section{BENEATH TROPIC SEAS}

few hours of intermittent observation I identified seventy-six species actually from the tree itself. Incidentally I found that all the birds collected, yielded valuable data as to food, molt, etc. So choose a pond or a tree or a field and make its individual census.

If you insist on lists however, for lists' sake, at least leaven the linear results with some unusual point of view. The fact that English sparrows, starlings, crows, robins, grackles and swallows are the most abundant birds seen on most of your tramps, although uninteresting knowledge to the half of one per cent, and wholly unknown to the ninety-four and a half per cent, is rather bromidic to the glorious remaining five per cent of us. One way to alchemize this effect is to preface the fact with the short but often embarrassing adverb, Why?

In this instance it spells trouble, for it sends us headlong to libraries and museums, to look up the earliest records and lists of birds. From the time of Columbus and Hendrik Hudson down to the last American Ornithologists' Union check list, there waits a tremendously interesting field for some one. Even the dullest of us five-percenters should see something significant in the fact that a century ago woodpeckers and creepers were far more abundant in New York State than robins and barn-swallows. If two decades ago I could have had the advance tip that English sparrows would, in time, decrease almost to the vanishing point in New York city, 


\section{THE NEW STUDY OF BIRDS}

I might have sold my draught horse stud-farms and invested heavily in Fords and taxicabs. The Isness of facts is boring and futile-the Whyness is the chief excuse for going on living.

Admitting that we have increased interest by limiting the field of work, let us consider still another new phase. Take a small field surrounded by woods. If we occupy some point of vantage for a whole day our senses will record a multitude of sights, sounds, and smells produced by living creatures ranging, say, from crickets to skunks. Now comes the exciting part, when we begin to realize something more than facts contained in our list of birds. Not only are there four robins within this domain, but these birds hold very definite positions and exert distinct influences. Take color for example, and grade it from the extreme of dullness to that of brilliancy in a scale of one to ten-a song sparrow at one end and a male scarlet tanager at the other. With this in mind, your census list becomes a pallid effect, and the most important thing is the new idea of a temporary neglect of names, substituting a thought of the birds as bits of pigment. From this point of view, compare them as a whole with the common butterflies of this same field. Then do the same thing with sound, and with subdivisions of sound-which species ranks as ten in regard to loudness or persistency or sweetness of tone? What insects or amphibians equal or excel them?

When you have learned the name of the indigo 


\section{BENEATH TROPIC SEAS}

bunting and then can at will discard it in place of some physical attribute, you have increased a thousandfold the interest of any place on earth.

Next to identifications, habits are of importance. But to start out to study the habits in general of the birds about you is a dilatory and vague thing, and if persisted in, may ultimately arouse in the mind unworthy thoughts of such ignoble, but at least complete, ideas as rubbers, sets, games, rounds, hands and matches. Give your interest in the habits of birds a focus, your efforts an objective, and limit your field of activity, and instantly the possibility of complete achievement will add immeasureably to your enthusiasm. How and where do birds go to roost, and how and when do they awaken? The effort at learning these is worth any daily dozen and a five foot library shelf.

One must move and observe quickly to accomplish much between the time when the first bird stops feeding in late afternoon and when the gathering dusk merges sparrows with leaves. I never considered the importance of roosting songs and rites and gatherings until I watched pheasants in the high Himalayas, and the last echo of this came only yesterday. I was peering over the sooty roof edge of my apartment building far down into the barren back yards, when I noticed sparrows converging. They were coming from all directions -only nine, where once there had been scores, but instead of roosting in some sheltered tree of the neighboring park, they had chosen the bare 


\section{THE NEW STUDY OF BIRDS}

radiating sticks of a clothes' drying tree. I was almost moved to tears as I had been some time before when I saw a trio of sparrows assembled in hopeless conclave about a pool of gasoline. With such denatured provender the survival of the fittest among these little immigrants has indeed become a forlorn hope.

Another thing about birds which is almost unstudied is what we might call individuality versus species personality. This has held my interest ever since I wrote about the spirit of the flock long years ago in Mexico. We know that one twin brother resembles the other in many characteristics and that members of a family have certain things in common. At a glance I have been able to distinguish between the members of two savage Dyak tribes, without being able to specify the evanescent clue of gait or gesture. Applying this to birds, a correspondingly vast and fertile field lies fallow. Color and pattern, song and general habits aside, what exactly sets a wood thrush apart from a robin or a veery? Such Whys and Whats make to think!

So closely have the lines of civilization been drawn that fines or a jail sentence wait upon the ornithologist who catches a native bird today and keeps it in captivity. That avenue is closed, and only at a zoological park may we watch native birds close at hand. But we can evade the law in many ways. Go to the bird stores and purchase foreign sparrows or thrushes or weaver birds and 


\section{BENEATH TROPIC SEAS}

place them in comfortable out-of-doors aviaries, and you will find our own species haunting the outside of the cage for hours at a time. Or get our native birds wonted to food and drinking places and any species will, in time, forget its fearfulness.

So if you wish, you may join the overcrowded ranks of those who have photographed a chickadee perched on a pipe or a cigarette full of seed, or who can proudly exhibit a film of a warbler feeding from the hand. Better than this, watch the visitors at a food pan through powerful glasses at close range and study the change in size of the iris, or the muscular control of feathers from crest to tail, or the use of the toes and beaks as tools, or the shifting psychological balance of fear and confidence.

One day you will realize and become aware (besides merely seeing) that birds have scales on their legs and toes, and again arises, like the voice of a great jungle frog, that everlasting, Why? Go at it both experimentally and with books-the idea of scales versus feathers. See if you can find any half-scale, half-feather on birds. Get scales from a lizard and a fish and try to make a feather, and then take a soft feather and attempt a scale. Check it all up with a good lens or a binocular microscope. Then beg a dead bird from the zoo, slay your neighbor's annoying parrot, or filch from your sister's old hat the bird of paradise which, for fear of fine and jail, she does not dare to wear. How many different kinds of feathers 


\section{THE NEW STUDY OF BIRDS}

can you find on the body; are they arranged hit or miss, any old way, or, whatever the answer, Why?

Finally, in the depths of winter, when birds are scarce, purchase a dozen hen's eggs, and rig up some kind of an incubator-any place where you can keep the temperature at about $103^{\circ}$. Then get a beginner's book on embryology and every other day, or at first, every few hours, chip open a carefully buttressed egg. If a New World was adumbrated by Columbus' balanced egg, perhaps a new sphere of interest may emanate from yours. Look within the shell with as much awe as you feel when you gaze up at the stars, or when you enter holy ground, whether Buddhist, Mohammedan or Christian. For in the latter case you are concerned with centuries of human efforts at sincerity, the stars lead your eyes through billions of miles of space, and the embryo in the hen's egg opens a vista to millions of years in the past.

When, in the midst of the tiny coagulation, you can detect the primitive streak, you have seen one of the real wonders of the world -a structure which links birds, animals, man himself, with the lowliest of jellyfish. Then, day by day, watch the new characters develop-the increase of segments from the first to the thirty-sixth, the great elliptical eyes, and the third Cyclopean eye. So strange is the embryo in shape that it is difficult to consider it as a living thing until suddenly one day the palpitating heart is discovered, and we know 


\section{BENEATH TROPIC SEAS}

that in spite of all the paddle-shaped hands and feet, the gills, the astonishingly long tail and beakless mouth, that eventually a fluffy, yellow chick will evolve and emerge from the shell.

When we have followed this marvel through the short three weeks of embryonic life, and realize that every bird in the world, from hummingbird to ostrich, has passed through identical stages, we return to a singing wood thrush with new comprehension and appreciation.

The plumage, eggs and the food of our common birds may have been well known for many years but under the stars of a night in May or September the beginner stands an equal chance with the most learned ornithologist. We are as yet only feeling our way to facts and theories of migration. On a misty night the heavens are filled with the low chirps and twitters of the winging hosts, and if for a few seconds the darkness could be dispelled, the clouds of birds in sight would be astounding. Opportunities for the beginner are manifold. In the field in the daylight he may so attune his ear to call-notes that he is capable of making an aural list, gleaned from an ornithological listening post throughout a whole night,- - something that, as far as I know, has never been done. Or he may so master the flight, the personalité en volant, of small birds that he may read the riddles on the face of the moon. With a good pair of binoculars mounted on a tripod, bird after bird may be seen traversing the great round window 


\section{THE NEW STUDY OF BIRDS}

of light, and I have detected two complete loops of a goldfinch silhouetted against the globe of glowing silver. Careful preparation may yield knowledge of flying height-estimated from the apparent size of the bird.

When the living stream of birds dwindles away, if one's wonder turns to moon mountains or to planets and nebulæ, then has ornithology given place to a very worthy substitute.

Cultivate the habit of looking up, even in the midst of a great city, and the occasional glimpse of a high circling hawk or a chevron of geese will be good for whatever ails you.

The difficulties of this study of the night flights of birds are greater even than those with which astronomers have to contend. We know with more or less certainty where birds breed and where they spend the winter, but the mystery of their going is so great that for many years it was believed that swallows hibernated in the mud. A new phase of bird study has arisen recently and even before the advance of mankind will have stamped out all but a few species, it seems as if we may learn many secrets now hidden. This new thing is tagging, or the placing of a tiny, numbered, light metal band on the leg of a bird. This anklet in no way discommodes the wearer and by the lucky accident of the bird being secured in a far distant country or retrapped at its home another season, we are accumulating a host of interesting facts. Thus the same white-throated sparrow has 


\section{BENEATH TROPIC SEAS}

been taken five years in succession in Georgia, each time after a breeding season in Canada. A gull nestling banded in England has been discovered three thousand miles away in Senegal, Africa, while black-headed gulls banded in Prussia have been traced to Barbados and eastern Mexico.

As is almost always the case with new experiments, there are unexpected results. Hundreds of nestling house wrens have been banded by an enthusiast in Ohio, and instead of the same pairs of cheerful little optimists rearing brood after brood, the fateful numbers on their tags revealed a most reprehensible state of affairs. When any one pair of birds finished building and laying and rearing their young, barely two days passed before they consummated a divorce, found new mates and industriously began new nests. One bird reared four broods in two years with the assistance of four different mates.

Future methods of ferreting out more migration secrets await discovery and application by anyone, and the few hints I have been able to suggest are as nothing compared with the field which lies at the very door of any of us who are unwilling to follow blindly in the conventional footsteps of preceding bird-lovers. But we must not delay too long. Artificial forests of rubber trees are replacing safe coverts of jungles; forest fires and ruthless wood-pulp vats destroy more of the haunts of birds than can ever be replaced, and in thousands of miles of China the masses of humanity are 


\section{THE NEW STUDY OF BIRDS}

using the very weeds for firewood. The most conservative and optimistic of us must admit that every twenty-four hours the bird life of the world is more curtailed and reduced. In a terribly short time there will remain on earth only those birds living in preserves and zoos, together with the few species which can adapt themselves to the devastating onrush of civilization.

And in those sad days the one-half of one percenters will answer as did the Queen who had drowned all her lovers, to the question of Ackazarpses:

"Illustrious Lady, you will sleep to-night?"

"Yes. I shall sleep sweetly." 


\section{APPENDIX A}

\section{THE HAITIAN EXPEDITION}

By William Beebe, Director

The Haitian Expedition was the tenth undertaken by the Department of Tropical Research of the New York Zoological Society. It numbered a staff of nine, and extended through a period of nearly five months, from January 1 to May 23, 1927.

Five chief objects may be cited:

(1) To prepare a list of Haitian fish, there being none in existence.

(2) To study at close range and at first hand by means of a diving helmet the life of a coral reef.

(3) To obtain motion pictures of the life of a coral reef.

(4) To test a wholly new idea of a floating laboratory.

(5) To see how inexpensive an expedition of this kind can be made.

(1) In the space of a hundred days, we secured over two hundred and seventy species of fish in one small area of the Gulf of Gonave, near Port-au-Prince Bay. It is interesting to note that in four hundred years there have been recorded from Porto Rico only three hundred species.

Our Haitian fish are being studied by Mr. Tee-Van and myself, and the list, together with considerable contributions to their life histories, will be published soon in Zoologica. A fisheries department is wholly lacking in the present occupational scheme of the Americans in Haiti, so duplicate collections were made for the Haitian Govern- 


\section{APPENDIX A}

ment, and a large amount of economical information was accumulated and left at their disposal.

(2) The director spent several hours every possible day, diving at one or the other of two reefs. These were located and photographed from airplanes and glass-bottomed boats, and their inhabitants were collected by means of hook-and-lines, nets, seines, set-traps, air-rifles, poison and dynamite.

(3) A brass box was made in New York City, fitted to hold a hand motion picture camera, and with this, on a weighted tripod, one thousand feet of splendid motion picture film was obtained by Mr. Floyd Crosby. These pictures were taken fifteen to thirty feet under water, and even at the greater depth showed full time exposure. Living coral of many species, sea-fans, sponges, and fish were photographed, and the diver in a second helmet can be seen in various activities demonstrating methods of study on the sea bottom. Once a barracuda swam so near the camera that it more than filled the entire screen.

(4) The idea of a floating laboratory proved perfectly practical. A four-masted schooner, the Lieutenant, was chartered in New York, loaded with the entire outfit and headed for Haiti, where she arrived seventeen days later. Her crew, except the captain, was shipped back to New York at once. She anchored two hundred yards from the naval wharf at Bizoton, and within a few feet of a coral reef. Here she remained for four months, with the exception of two short tows to the Panama steamer across the gulf, for two thousand gallons of New York Croton water. An automobile on the shore kept us in contact with Portau-Prince, three miles away.

We lived in nine tents on deck, where a small gasoline engine provided us with ice and electric light.

In glass-bottomed and other boats and in the schooner's big motor launch, we made constant trips to the two selected coral reefs off shore. On the schooner we were able to avoid 


\section{APPENDIX A}

dangers and annoyances such as malarial mosquitoes and inquisitive natives, and both days and nights were cool.

(5) The total expense of the expedition, for schooner, outfit, staff of nine, five months in Haiti, is as follows:

Outfit................. \$ 3,209

Engine, ice and light.......... 1,193

Photo supplies............... 1,489

Food and coal............... 1,196

Motor car............... 1,184

Fares..................... $\quad 943$

Schooner................. $\quad 5,936$

$\$ 15,150$

Exclusive of salaries, the sum arranged for and provided by the generosity of members of the Zoological Society was ten thousand dollars. The additional amount was contributed by the director. The total cost, considering the number of the staff and the facilities afforded by the schooner and outfit, is probably the lowest with which any similar expedition was ever undertaken and achieved.

The following members of the Zoological Society, by their generous contributions, made this expedition possible:

George F. Baker

John C. Berwind

Robert Brewster

Coleman du Pont

Marshall Field

Edward S. Harkness
Anthony R. Kuser

Ogden Mills

Lewis R. Morris

George D. Pratt

Mortimer L. Schiff

Frederic C. Walcott

\section{Harrison Williams}

As regards the personnel, John Tee-Van and William Merriam were, as usual, my main stays. We three have been off so many times now, that our mutual activities seem to be accomplished more by sub-conscious instinct than otherwise. Mark Barr was new to expeditions, and 


\section{APPENDIX A}

invaluable in his three-fold field of physicist, master electrician and philosopher. Dr. Jamie Jamieson has made the item-Humorous and Able Scotch Surgeon-an indispensable one for future expeditions. Floyd Crosby's photographic work was excellent, and Benjamin Waring was an admirable all around helper. Serge Chetyrkin, as usual, was indefatigable as collector and preparateur. Helen TeeVan worked hard and most skilfully at her painting, and completed upwards of one hundred valuable studies of fish and invertebrates. Mrs. Boyden and Alice Robinson accomplished much with the domestic affairs of the expedition. On shore Capt. Perfielieff and Mr. Church were semi-detached expeditionary artists, roaming about and making excellent paintings of landscapes and native types.

From first to last, the American High Commissioner and his wife, General and Mrs. John H. Russell, never lost an opportunity to further our work, and in this they were heartily seconded by President and Madame Borno. In fact, a list of those who rendered invaluable assistance would necessitate a roll-call of the entire American Force of Occupation-aviators, scientists, officers of the Marines, and heads of all departments. In particular I must mention Commander V. Wood and Dr. George Freeman.

We had a particularly interesting lot of visitors, the possibility of going down in the diving helmet proving as strong an attraction as Haiti and the Haitians. Our anchorage might have been a box at the first night of some wonderful performance, so numerous were the unexpected thrills. The Marquis de Pinedo in his ill-fated Santa Maria Italian plane taxied near us on his arrival, and the next morning took off. His plane was burned later at Roosevelt Dam, Arizona. The Good Will Flyers landed almost under our bows, one after the other, and cached their planes at the Naval Station a hundred yards away. I took Captain Eaker, pilot of the San Francisco, out to Sand Cay, where he dived time after time, deeming it 


\section{APPENDIX A}

more exciting than any experience he had had in South America. He loaded his plane with corals and sea-fans which he brought up from the bottom with his own hands.

Secretary of War Davis and Senator Oddie were men of such heroic proportions that $I$ had difficulty in fitting the helmet over their massive shoulders, but once submerged, their enthusiasm at the wonders of a coral reef was unbounded.

A remarkable coincidence was the arrival of another converted four-masted schooner, the Four Winds, with Vice-Admiral Sir Guy Gaunt on board. She anchored within a stone's throw of us for a week. Admiral Gaunt has had almost every experience the sea can offer a sailor, but when he climbed up the diving ladder and dehelmed he said that never before had he met the ocean's inhabitants on such terms of equality, as man to fish.

Other visitors included the yachting parties of Mr. and Mrs. Charles Mitchell and Mr. H. H. Rogers; Dr. Alexander Wetmore, Dr. Frank Chapman, Elswyth Thane, Charles Beebe, John van Dyke, Margaret McElroy, Dr. and Mrs. Frank Damrosch and Joseph Sheffield.

New methods of studying and collecting specimens come to light with each expedition, and now the deep-sea telephone is approaching perfection. This is the work of the Bell 'Telephone Laboratory assisted by Dr. Mark Barr, and will eventually do away with the limitations of notes jotted on a zinc tablet, as the diver will be enabled to dictate his observations to some one on the boat. Most valuable electrical material was contributed by Mr. Samuel G. Hibben.

The spoils accruing from our attendance at a Marine Corps bombing practice, led to our use of small charges of dynamite below the surface, and this proved to be the only means of securing certain shy fish which peeped out from rock crevices with no interest whatever in bait 


\section{APPENDIX A}

or traps. The two thousand candle power electric light bulb submerged beside the gangway again proved most successful in attracting an amazing variety of lifefrom minute larvæ and swimming embryos to large jellyfish, with fish circling slowly through the drift of plankton round the light.

The general impression of hours and days spent at the bottom of the sea is its fairylike unreality. It is an Alice's Wonderland, where our terrestrial experiences and terms are set at naught. The flowers are worms, and the boulders living creatures; here we weigh but a fraction of what we do on land; here distance is sheer color and the sky is a glory of rippling light. Here we can support ourselves with the crook of our little finger, and when we let go we fall tco slowly for injury.

Until we have found our way to the surface of some other planet, the bottom of the sea will remain the loveliest and strangest place we can imagine. 


\section{APPENDIX B}

CONDENSED LIST OF EQUIPMENT USED DURING THE HAITIAN EXPEDITION

Transport

128 foot motor life boat, square-sterned, open; equipped with 2 cylinder motor capable of producing 7 to 8 knots; completely furnished with oars, anchors, lights, etc.

2 row boats, 15 feet long; flat-bottomed, with glass port about 16 inches square in well in center; equipped with oars, rowlocks, anchors and rope.

1 row boat, 15 feet long, flat-bottomed, with oars, rowlocks, ropes and anchor.

1 row boat, 16 feet long, round-bottomed, equipped as above.

3 Johnson outboard motors, for use on rowboats listed above.

1 Ford station-wagon, used for transporting equipment to inland lakes.

Extra parts for motor repairs.

Tools for motor repairs.

Gasoline, oils and greases for motors.

\section{Living Supplies}

7 Wall tents, equipped with flies and poles,-varying in size from $14 \times 14$ feet to $8 \times 8$ feet. tarpaulins,-used for covering runways on deck of Lieutenant between tents, and over aquariums and photographic apparatus. 


\section{APPENDIX B}

tables, folding cots, folding chairs

sheets, pillows, blankets, towels

washbasins

plates, cups, saucers and other tableware

napkins, oilcloth

cooking utensils and kitchenware

fuel for cooking

electric refrigerator

food, preserved and fresh;-Cost, estimated before leaving on Haitian Expedition, $\$ 1.25$ per day per member of staff. Actual cost at finish of Expedition,

$\$ .78$ per day per person.

medical supplies and medicines

\section{Lighting}

1110 watt electric generator with suitable appurtenances

to supply necessary light and power to quarters and laboratories and for submerged lamps

3 submersible diving lamps, 150 to 2000 candlepower, with waterproof cables; used for investigating the bottom at night and for attracting animals

1 case containing an assortment of colored electric lights capable of being submerged,- - each lamp with a definite known wave length. These lamps were used underwater for experimenting on the color receptivity of marine animals

1 case containing similarly tested colored lamps, but not submersible

Gasoline, oil and greases for generator

\section{Diving Materials}

4 Diving Helmets, complete with weights, hose, pumps, base-boards for pumps, washers, etc.

2 metal ladders, collapsible, for descending to the bottom from the diving boats; equipped with shackles or ropes to fasten them to the boat 


\section{APPENDIX B}

glycerine, for inside of glass of helmet, to prevent breath condensing on the glass and obscuring vision

cloths for cleaning glass

\section{Collecting and Obsenvirig Equipment}

duffle bags, carrying bags

collapsible observation tent, made of green denim; like

tree trunk in appearance

seines, ranging from 20 feet long with $1 / 4$ inch mesh,

to 300 feet long with 3 inch mesh

gill nets, 100 to 300 feet long

silk plankton tow nets, 1 foot, $1 / 2$ metre and 1 metre in

diameter; used for capturing the minute life which

forms the ultimate food supply of fishes

crab-nets, with poles 6 to 10 feet long

scoop-nets, short-handled

butterfly nets

harpoons, hand

harpoon guns, with harpoons and rope

grains

dynamite, with fuses, wires and blasting machine

poisons for fish

fishing tackle,- - poles, lines, sinkers, flies, etc.

traps, underwater

dredges

traps, mice, rat, etc.

under-sea spring guns

shotguns, 12 gauge and .22 calibre

auxiliary barrels for .32 calibre shot-shells

ammunition for above and for harpoon guns

gun grease, solvents, cleaning tools

pails, galvanized and canvas

wash tubs, galvanized iron and wood

large, flat white enameled pans

miscellaneous bottles and vials

mosquito netting 


\section{APPENDIX B}

flashlights and batteries

thermos bottles

compasses

knives

\section{Photographic Equipment}

1 Akeley motion picture camera, complete with tripod, magazines, 2, 4, 6 and $12^{\prime \prime}$ lenses

1 Debrie high-speed motion picture camera, with tripod, magazines, and 2 and $6^{\prime \prime}$ lenses

1 De Vry motion picture camera, with two $2^{\prime \prime}$ lenses, working at $f .1 .9$ and f. 3.5

1 Brass water-tight box, for holding De Vry camera, used for submarine photography

1 Graflex camera, $4 \times 5$, with plate holders, cut-film magazines, etc.

2 view cameras, $4 \times 5$, with plate holders, tripods, focussing cloths, etc.

1 vertical camera, $4 \times 5$, for photographing specimens

3 miscellaneous film cameras

1 tripod for photographing under water, metal topped

1 measuring rod, 6 feet long, made of metal, for measuring distances when photographing under water

filters and filter holders for various cameras

flares for night photography

flashlight gun and powders

panchromatic motion picture film

photographic plates, cut film and roll film

autochrome plates and filters

photographic chemicals for developing and fixing

reducers and intensifiers

dark room lights

graduates and stirring rods

developing trays and boxes

fixing boxes

washing baths 


\section{APPENDIX B}

drying racks

printing frames and papers

film preservers

thermometers, hydrometers

camel's hair brushes

miscellaneous photographic equipment

photographic aquariums

black velvet for backgrounds

gray, white and colored cardboards for backgrounds

\section{Laboratory Equipment}

aquariums of various sizes, ranging from $12^{\prime \prime} \times 6^{\prime \prime} \times 6^{\prime \prime}$ to $30^{\prime \prime} \times 18^{\prime \prime} \times 18^{\prime \prime}$

microscopes,-binocular dissecting, ordinary dissecting, high power

dissecting lenses

microscope slides and cover glasses

forceps, scissors, scalpels, dissecting needles, etc.

scales, calipers, rules, tapes

stender dishes, watch crystals

filter troughs, rectangular

thermometers, alcoholometers

skinning tools

tape-adhesive, cloth

3 in 1 oil

injecting syringes and needles

cyanide bottles

small homeopathic vials, ranging up to 3 inches by 1 inch 4 and $6 \mathrm{oz}$. wide mouth bottles with corks

mason jars, wide mouthed, $1 / 2$ pint, 1 pint and 1 quart 5 gallon earthenware jars

10 gallon metal milk cans

50 gallon barrels

empty kerosine tins, for shipping specimens

plaster of paris, beeswax, paraffine, for making casts of fish 


\section{APPENDIX B}

alcohol, formalin

anæsthetics for marine animals,-chloretone, chloral hydrate

chloroform, ether, cyanide

napthaline

arsenic

miscellaneous chemicals

insect boxes, insect pins

labels of various kinds, metal, paper, cloth

botanical paper

cheesecloth, large quantities

absorbent cotton

waterproof ink

assortment of stationery,-paper, pens, etc.

printed forms for specimens-to be filled out when fish or other animal is being studied

\section{Artist's Supplies}

water color and oil paints, inks

canvas and paper

brushes, pens, pencils, etc.

\section{Miscellaneous}

assortment of carpenter's, plumber's and machinist's tools

for making necessary repairs to equipment and for making experimental devices assortment of nails, screws, bolts, etc. lumber,-mainly flat boards to be used for shelving, $2 \times 4^{\prime \prime}$ studs, etc. galvanized iron sheets, etc. rope, from $1 / 4$ to $3 / 4$ inch diameter, large quantities 


\section{APPENDIX C}

METHODS IN SUBMARINE PHOTOGRAPHY

By John Tee-Van, General Assistant, Department of Tropical Research

Ever since diving helmets were introduced as regular equipment of the Department of Tropical Research by Mr. William Beebe, practically every emergence from the water has been accompanied by a spoken or silent wish that the experiences and sights witnessed under the sea, might be recorded in some tangible way, and brought back to the many who have not been fortunate enough to go below the surface and witness the life that goes on there. These wishes were answered to a slight extent by the return last year of the Haitian Expedition, bearing twelve hundred feet of film taken below the surface by Mr. Floyd Crosby, portraying the life of the coral reefs.

Submarine photography is such a recent matter,-the first attempts having been made but thirty-five years ago, and of such unusual occurrence, that the apparatus employed in procuring the pictures is of more than passing interest.

As the work of the Haitian Expedition related almost entirely to the study of fishes and their habits, very little time could be devoted to photography alone. Under such conditions it was imperative that the under-water motion picture camera be simply made, easy to operate, not too large or heavy, and yet capable of doing the most exacting work under the surface, using sunlight only as an illuminant.

Such a camera was made before we left New York for Haiti as the result of plans worked out by Mr. William 


\section{APPENDIX C}

Beebe, Mr. Mark Barr and myself, the actual construction being in the hands of Mr. J. Schrope, foreman machinist of the American Museum of Natural History.

In brief, it consisted of a brass, water-tight case, into which a camera was inserted. The camera chosen was a motor driven De Vry, using standard $35 \mathrm{~mm}$. film and equipped with its regular f. 3.5, two-inch focal length lens, and a two-inch f. 1.9 lens. It was selected after careful consideration of the smaller, motor driven cameras mainly because of its shape,-a rectangular box, about which it would be simple to fit a brass case. The choice was justified by the mechanical operation of the camera, as it performed perfectly and did everything that was required of it.

The outer, water-tight, brass case that allowed the camera to be taken underwater, can be more easily understood by reference to the illustrations. It consists of a rectangular box with outside dimensions as follows: length $121 / 4$ inches, height $77 / 8$ inches, width $5 \frac{1}{4}$ inches. It is made of $1 / 4$ inch thick brass, recessed on the sides and top wherever it could be done without weakening the structure, so as to lessen the weight as much as possible. The box and camera loaded with film and ready to go under the surface weighs thirtynine pounds.

The front end of the case contains a plate glass port $2 \frac{1}{16}$ inches in diameter and $1 / 4$ inch thick, through which the photographs are taken. The port is centered, of course, with the axes of the lenses and the center of the film. Space was left in the box between the lenses and the port for filters, but they were not used during the expedition.

The rear end of the box is open so that the camera can be inserted. It is closed by a brass lid held tightly in place by ten butterfly-nuts, - a large rubber gasket being inserted between the lid and the box, making the joint so tight that not a single drop of water entered the camera during the months that it was used in Haiti. 


\section{APPENDIX C}

A small handle placed on top facilitates carrying the box and is of utmost importance in lowering the camera by means of a rope, to the diver.

On the right side of the case is the lever which controls the starting and stopping of the camera. The lever shown in the photograph is one long bar of an elongated $U$ which is pivoted in the side of the camera at the base of the $\mathrm{U}$. The other and inner long bar of the $U$ is forked at its distal end and fits about the starting button of the camera. To make this possible, the starting button supplied with the camera was removed and one shaped like a flattened spool was installed in its place. Thus, when the outer lever is pushed downward, the starting button also moves down and the camera photographs. When it is pushed upward the camera stops.

Because the starting lever does not move more than $3 / 8$ of an inch at its outer end, it was decided that all the motion could be taken up by utilizing the stretching qualities of a large disk of heavy rubber, and that it was unnecessary to make a stuffing box to avoid leaks at the joint. This disk, as can be seen in the photographs, was held in place by a brass ring, and firmly cemented to the case at its periphery. At its center, it is cemented between and held in place by two large flat washers, the lowermost of which is part of the bottom of the U. Thus when the starting lever is moved downward the rubber merely stretches a little around the circle. This joint, as can be seen, is simple and fool-proof, the only possibility of a leak being through the rubber, and when two sheets are used the likelihood of this happening is not very great.

As the camera box is not a perfect rectangle, having protuberances such as starting buttons, finders, etc., it does not fit the box exactly. 'To prevent the camera rattling, thick pieces of rubber, an inch wide and half an inch thick and as long as necessary, were inserted on the sides 


\section{APPENDIX C}

and top. These were removed every time the camera was taken out of the case, but they are now incorporated as part of the brass box.

Using the camera in the field resolved itself into the following procedure. A reef having been found where conditions such as adequate scenic effects and sufficient numbers of fish could be found, the photographer went down in his helmet and decided upon a suitable background or place to photograph. After choosing the spot he measured off the distance to where the camera was to be placed, appraised the amount of light, and ascended to the surface. The camera was then loaded with film, wound up, the lens set, because of the refraction of the water, to twothirds the distance measured below, and the diaphragm adjusted to whatever aperture was considered necessary.

The diaphragm setting employed during most of our photography at depths of eight to fifteen feet, between the hours of ten-thirty and one-thirty with bright sun as near overhead as it could be, was between f. 5.3 and f. 8 using an f. 3.5 lens. Although we possessed a lens with an aperture of f. 1.9 we found that fully exposed negatives were obtained using the exposure mentioned. The speed of the camera, of course, was standard,- - sixteen exposures a second.

After the adjustments were made, the photographer descended and the camera was lowered to him. He then placed it on a tripod having a metal top,- - the metal being mostly to prevent the tripod floating away. The fish were baited if it was necessary to concentrate them in one spot, and the photographer pressed the lever whenever he decided that the results would be worth while. The absence of the slight vibration of the camera indicated when the spring had run down and the camera had stopped. It was then sent to the surface, rewound or new film inserted if necessary, and again sent below. The camera contained one hundred feet of film and ran for fifty feet on one winding. 


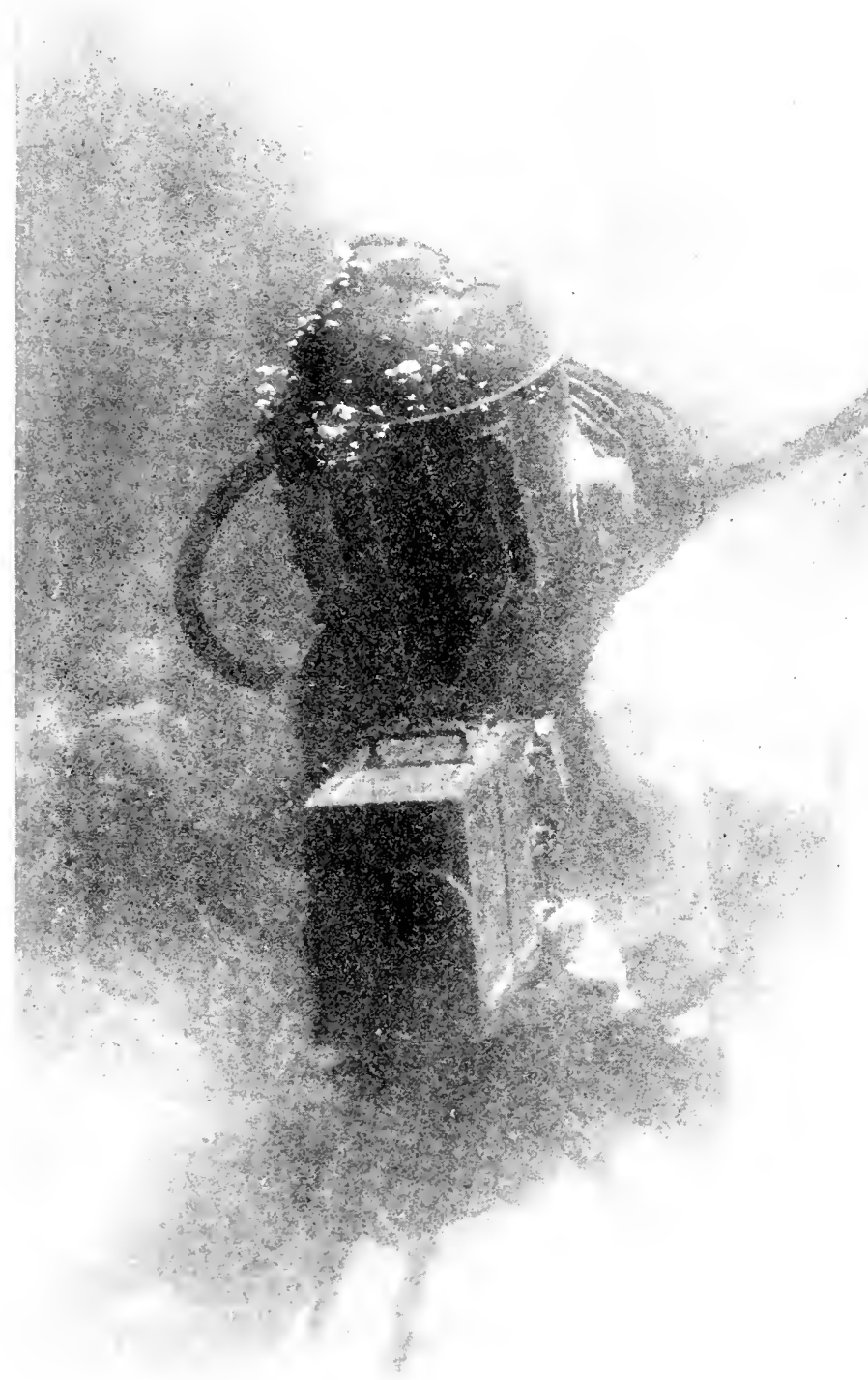

Floyd Crosby Taking Motion Pictures of a Haitian Coral Reef 


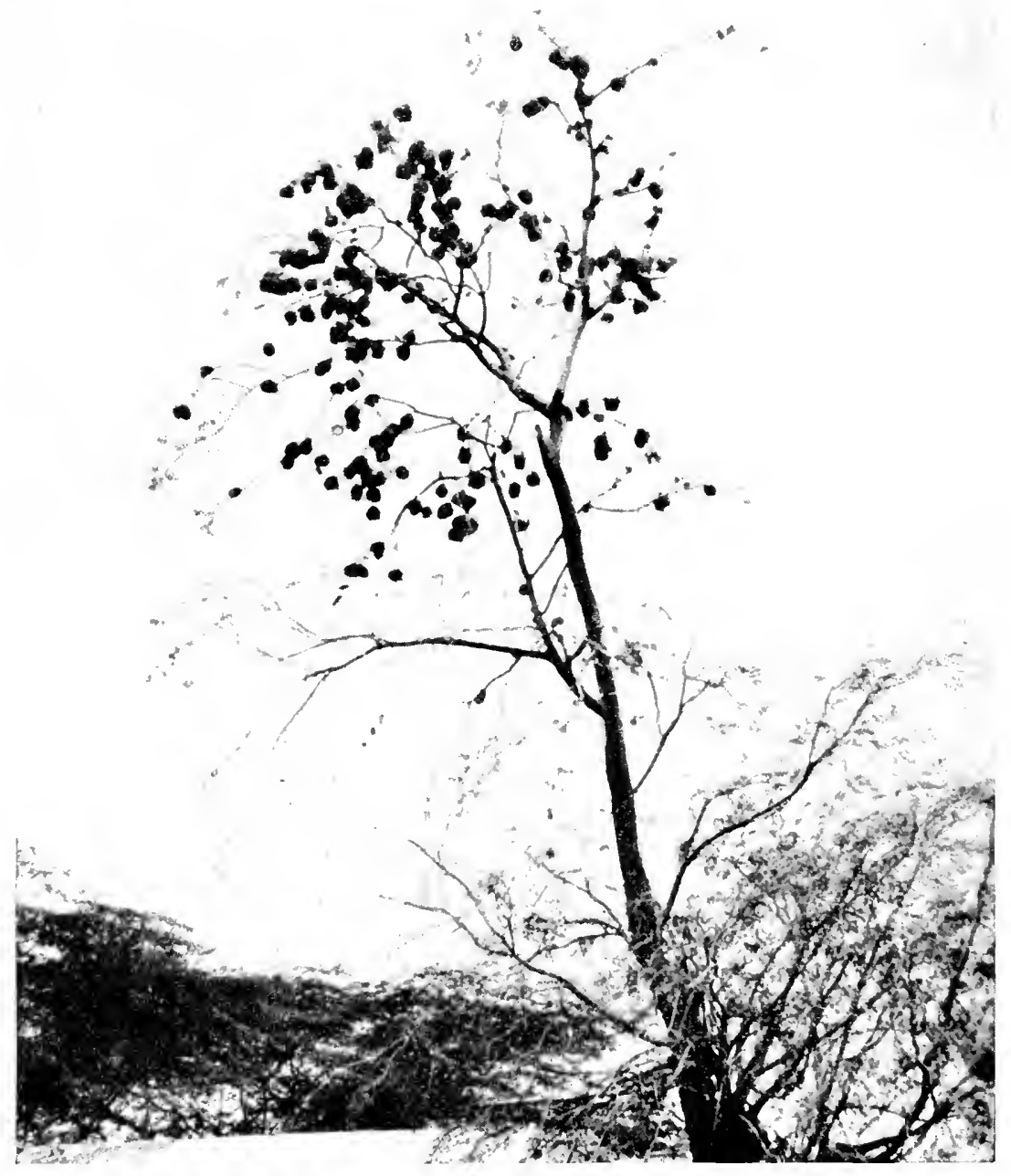

Nesting Colony of Black-headed Weaver, Hyphanthornis c, cucullatus, near the Flying Field, Port-au-Prince

This bird has been imported from Africa 


\section{APPENDIX C}

Panchromatic film was used, without filters, for under water work, - the film being supplied with extra long red leaders and tail pieces. Although these made the film supposedly day-light loading, we took no chances and always used a loading bag.

In the waters about Port-au-Prince we found that beyond twenty-five feet from the camera, the haze in the water was too great to pick up more than vague outlines on the film. In clearer water, further distance might easily be attained.

After using this camera under water for four months, certain suggestions regarding improvements can be made. Two of these, of little importance, are to make the handle on the top larger, so that four fingers can easily grip it, and to place larger butterfly-nuts on the rear lid. With fingers wet and drawn and sensitive after a few hours of diving, tightening the small nuts brought about a considerable amount of profanity that might easily be obviated.

A third improvement, of greater consequence, would be to place a finder on the upper surface of the case or on the left hand side, that would indicate the field visible on the film. After a certain amount of experience it is fairly easy to operate the camera without a finder, but having one would simplify matters. The making of this finder is not as easy as it appears to be. This is so, first, because the diving helmet does not allow the wearer's head to come as close to the camera as it would in the open air, and lining up two points is a more difficult task than it is above water and secondly, the refraction of the water must be taken into account.

As can be seen, the apparatus is as simple as it could possibly be, and the resulting photographs have proved of great beauty and of real scientific worth. It is hoped that this simplicity will induce more people to descend and photograph and bring back records of the only other world from which we who live on earth, can return. 


\section{APPENDIX D}

\section{LIST OF HAITIAN BIRDS OBSERVED}

Seldom have I seen such abundance of life under water as in the Gulf of Gronave, and such dearth of living organisms as above it. From the deck of my schooner I watch the sun rise suddenly over the farther end of the valley of the Cul-de-Sac, and roll its violent light down the wide, sloping stretch of semi-arid land. As the day dawns a bell or two rings in the distance, burros bray, cocks crow, but the morning chorus of the tropics hangs fire. If I were deaf to all but human sounds there would be only silence. Then my straining ears catch a call quite out of place-whu! bob-white! from far up the mountain slope, and we have Haiti's ornithological face saved by this member of the northern family of quails. Before I give up hope a single native call comes across the water. Through the glass I see a trio of Haitian grackles flying from palm to palm, and they send out a clear strain, so meadowlark-like that it changes the scene to a frosty day in a northern meadow.

If the tide is falling, continual watching will be rewarded by a single great blue heron or a solitary egret, or one Louisiana heron winging its way to some shoal, or more rarely a sharp-winged royal tern flying past. Once, and once only, in three months, a laughing gull was seen perched on a coral crag, and was an event. Twice, in the hundred days of our stay, a frigate-bird soared past high overhead. An osprey tried unsuccessfully one day to alight on a mast top, overburdened with a large fish in the claws of one foot. Two groups of pelicans haunted our side of the gulf, one at Sand Cay and the other at Lamentin Reef. We shot 


\section{APPENDIX D}

one of the former to learn its food, and an overenthusiastic Haitian assistant did away with two others.

On six evenings an owl flew low over our submerged light, swooping time after time close to the illumination, hoping perhaps, for the insects which experience had led the bird to look for near lights on land. So much for bird life from the schooner.

I had occasion to make many trips to a sandy beach at Bizoton, about a mile west of the Lieutenant and the Navy Yard. Now and then I spent an hour walking about the fields immediately back of the shore at this point. As almost everywhere in Haiti the land showed signs of present or past human occupation. A thin fringe of mangroves stretched along the beach, growing in mud-flats which were a paradise for fiddler crabs. In my beat I included the outskirts of a sugar-cane plantation and several rice or paddy fields. The overgrown embankments of the latter looked like the trenches of past battle-fields. Along these was a scattering of young trees, with a few coconut and royal palms.

In this area, about one-quarter of a mile square, I observed thirty-six species of birds during my stay, shooting some, watching others. Elsewhere on the island I obtained specimens or identified forty-six more, making a total of eighty-two species altogether. My list of Haitian birds follows, as closely as possible, the third edition of the American Ornithologists' Union Check List.

The following notes were made between January second and May eighteenth, 1927:

San Domngan Grebe, Colymbus dominicus

Six seen in pairs at close range, swimming and diving in Etang Miragoane, March 2, 1927. A second species of Grebe was seen but I could distinguish no certain marks of identification.

Laughing Gull, Chroicocephalus atricilla 


\section{APPENDIX D}

One perched on a projecting coral stub was the only individual seen.

Noddy Tern, Anous s. stolidus

An unmistakable Noddy flew swiftly past the schooner early one morning after a very severe storm which had lasted most of the night. No other individual was seen throughout our stay.

Royal Tern, Thalasseus maximus

A single bird seen and heard several times near the schooner.

Yellow-Billed Tropic-bird, Phaethon americanus

Two birds seen, 10 miles off Mole St. Nicholas on January 17th, 1927. A third flew over the Lieutenant.

Brown Pelican, Pelecanus o. occidentalis

Six constantly fishing at Sand Cay, and 10 to 17 at Lamentin Reef throughout our stay. Only 1 or 2 fully adult.

Frigate-BIRd, Fregata magnificens rothschildi

Two seen soaring high overhead. Fifty or sixty were breeding in January on Frigate Island, off the northeast coast of Gonave Island.

Green-winged Teal, Nettion crecca carolinensis

Rare, three were examined in a hunter's bag in Portau-Prince.

Blue-winged Teal, Querquedula discors

Fifty-three shot in one small lake and marsh on March 2nd. The latest migrants were noted on April 12th.

Lesser Scaup Duck, Nyroca affinis

Four off-shore early in January.

Bahama Duck, Preilonetta $b$. bahamensis

Four pairs at Source Matelas in mid-January. West Indian Tree Duck, Dendrocygna arborea

Three seen on the wing flying over Source Matelas preparing to settle. When they discovered me, they rose hurriedly and flew off.

Flamingo, Phonicopterus r. ruber 


\section{APPENDIX D}

Twenty-one in two flocks at Etang Saumatre on March 15th. They joined and flew slowly past and quite near us. Said to nest in a large colony on the opposite shore of this salt lake.

Great Blue Heron, Ardea herodias subsp.

One full-sized immature bird shot close to the schooner, and two others seen in inland lakes.

American Egret, Casmerodius albus egretta

A solitary bird flew back and forth past the schooner to feeding and sleeping places during three months of our stay.

SNowy Egret, Egretta t. thula

Six or eight seen at Lake Miragoane on the 2nd of March. Louisiana Heron, Hydranassa tricolor subsp.

Rarely seen. Three along shore.

West Indian Green Heron, Butorides virescens subsp.

The common heron, feeding at Bizoton among the paddy fields and mangroves.

Yellow-crowned Night Heron, Nyctanassa violacea subsp.

A single bird fished along the shallows of Bizoton.

Clapper Rail, Rallus longirostris subsp.

A bird seen twice, while walking within a few feet of me at Bizoton sand beach.

Florida Gallinule, Gallinula chloropus cachinnans

A live one brought to me at Etang Saumatre, and several seen and heard at Etang Miragoane.

American Coot, Fulica a. americana

Four seen in pairs at Etang Miragoane, March 2nd.

Black-necked Stilt, Himantopus mexicanus

At Source Matelas and Etang Miragoane, several pairs. Two shot at former place were feeding upon Corixids.

Least Sandpiper, Pisobia minutilla

Small flocks from time to time passing along shore and at Source Matelas, from which I secured two.

Semipalmated Sandpiper, Ereunetes pusillus 


\section{APPENDIX D}

Two only, seen at close range along shore.

Greater Yellowlegs, Neoglottis melanoleuca

Small flocks always at Source Matelas. One taken March 21st.

Lesser Yellowlegs, Neoglottis flavipes

A flock of 21 at Source Matelas, mid-January.

Willet, Catoptrophorus s. semipalmatus

Five at Source Matelas in mid-January.

Spotted Sandpiper, Actitis macularia

Single individual seen along shore almost every day. Hudsonian Curlew, Numenius hudsonicus

Three birds kept just beyond gun-shot on the marshes of Etang Saumatre.

Antillean Killdeer, Oxyechus vociferus rubidus

A few pairs near all inland lakes.

Haitian Thicknee, Edicnemus dominicensis

Two birds seen along shore at Etang Saumatre, March 15th by John Tee-Van.

West Indian JACANA, Jacana spinosa violacea

In small numbers in marshes at Etang Saumatre, March 2nd.

Bob-white, Colinus virginianus subsp.

Heard at Bizoton every morning, and at Etang Miragoane.

Guinea Hen, Numida g. galeata

Common in the dry cactus and acacia scrub inland. Flushed flocks of 20 to 30 with the car, or rather frightened them, for they almost always ran into the thickets at the roadside.

White-winged Dove, Melopelia a. asiatica

Fairly common, feeding in trees both near the shore and in the interior. Two other species of dove were seen but not identified.

Cuban Ground Dove, Chremepelia passerina aflavida

Common in pairs running along the roads or flying through the cactus scrub. 


\section{APPENDIX D}

Red-tailed Hawk, Buteo borealis subsp.

A pair seen several times circling high in air.

Haitian Sparrow-Hawk, Falco sparverius dominicensis

Fourteen seen during our stay, all solitary, well up in the mountains, feeding near the road.

Osprey, Pandion halicetus carolinensis

The only individual seen tried to alight on one of the masts on March third. Having a large fish in the talons of one foot, it failed to perch and flew away.

Haitian Barn Owl, Tyto glaucops

One visited the Lieutenant on six evenings flying around the schooner and swooping into the light. A female taken alive at Bizoton.

Haitian Burrowing Owl, Speotyto dominicensis.

Abundant, flying from the road at night in pairs in the light of approaching automobiles.

Haitian Parrakeet, Aratinga c. chloroptera

In small flocks well up from the shore.

Hartian Parrot, Amazona ventralis

Ten seen altogether, in pairs. None near the shore. A number of nearly grown ones in cages at Port-au-Prince and Petit Goave.

Haitian Tody, Todus subulatus

Not rare, generally distributed.

ANI, Crotophaga ani

In families or small flocks along the roadside.

Yellow-Billed Cuckoo, Coccyzus a. americanus

One seen close at hand and heard calling in a garden at Port-au-Prince.

Haitian Lizard Cuckoo, Saurothera dominicensis

Common, both along shore in the mangroves and in the large gardens. Several times I saw them catch and swallow small lizards, and one shot had three in its stomach.

Haitian Trogon, Tennotrogon roseigaster

A single bird seen and heard in dense woods beyond Miragoane in January. 


\section{APPENDIX D}

Belted Kingfisher, Megaceryle a. alcyon

A few seen along shore and at Etang Miragoane March 2nd.

Haitian Wood-Pecker, Chryserpes striatus

Not rare among the larger trees of the uplands. Ruby-throated Hummer, Archilochus colubris

A male hummed about my head for several minutes, and then perched a few feet away at Bizoton sand beach on March 6th. As far as visual reliability alone can be trusted, this is an absolute identification.

Haitian Mango Hummer, Anthracothorax dominicus

Not rare, both near the sea and at a mile elevation.

Haitian Vervain Hummer, Mellisuga catherince

Common near Port-au-Prince. This, the second smallest bird in the world, is less than $21 / 2$ inches in total length, and on the wing looks like a large bee.

Gray KingBird, Tyrannus d. dominicensis

Singly, not rare in open dry cactus.

Haitian Crow, Corvus leucognaphalus erythropthalmus

Common in pairs or families in dry cactus country. Typical crows, but in miniature.

Haitian Oriole, Icterus dominicensis

Seen now and then flying among the palms.

Haitian Grackle, Holoquiscalus niger

Very common in families or flocks, but much more musical than our other representatives.

Haitian Bullfinch, Pyrrhulagra violacea affinis

Two individuals of this unmistakable species, in full color, apparently males, came to the schooner and perched quietly on the ratlines until a gun was loaded, when they flew straight out across the Gulf and were not again seen. Olive Grassquit, Euetheia bicolor marchii

Rarer than the yellow-faced bird at Bizoton. Yellow-Faced Grass-Quit, Euetheia o. olivacea

Not common in grassy fields. 


\section{APPENDIX D}

Black-headed Palm Tanager, Phonicophilus palmarum, Two seen.

Black-headed Weaver, Myphanthornis c. cucullatus

Two seen at Bizoton Sand Beach. Others were nesting in cocoanut and royal palms at Miragoane, and a colony of about 100 nests in a single isolated tree at the flying field at Port-au-Prince.

Caribbean Martin, Progne dominicensis

One or two pairs seen on each excursion into the mountains.

Cliff Swallow, Petrochelidon fulra subsp.

Eight cliff swallows flew about the Gendarmerie Dak at Furcy the first day I went there. Not seen again.

Barn Swallow, Hirundo erythrogaster

Three swallows flew around the schooner about noon on February 20th for several minutes.

Palm Chat, Dulus dominicus

The typical bird of Haiti and the most abundant. Noisy and active and present in small flocks in gardens and fields. Honey Creeper, Careba bananivora

Four seen, 3 in full song.

Black and White Warbler, Mniotilta varia

Common. Several shot.

Northern Parula Warbler, Compsothlypis americana usnea

Three seen, one taken.

Cape May Warbler, Dendroica tigrina

One shot from a party of seven.

Black-throated Blue Warbler, Dendroica c. corulescens

One seen and shot.

Jamaican Yellow Warbler, Dendroica $p$. petechia

Not uncommon in varied habitats.

Myrtle Warbler, Dendroica coronata

Two seen.

Palm Warbler, Dendroica $p$. palmarum

Three seen. 


\section{APPENDIX D}

Prairie Warbler, Dendroica discolor

Five seen, one taken.

Water-thrush, Seiurus n. noveboracensis

One seen at Furcy.

Southern Yellow-thront, Geothlypis trichas ignota

Female shot, associated with, presumably, the male at Bizoton Sand Creek. The male raised a great outcry when his mate was killed, and did not leave the particular bush for an hour.

Northern Yellow-throat, Geothlypis trichas brachydactyla

Four seen in pairs, one shot.

American Redstart, Setophaga ruticilla

Common. A pair, identifiable from lost feathers,-fed within the space of four trees in General Russell's Port-auPrince garden, throughout three and a half months.

Haitian Mockingbird, Mimus polyglottus dominicus Common everywhere.

W. B. 


\section{APPENDIX E}

FAMILIES AND NUMBER OF SPECIES OF HAITIAN FISH COLLECTED DURING THE EXPEDITION

Number of

Family Name Common Name Species

Class Elasmobranchii: Sharks, Rays, etc.

Orectolobida

Nurse Sharks

1

Squalida

Dog-fish

1

Carcharinida

True Sharks

3

Cestraciontida

Hammer-head Sharks

1

Dasybatida

Sting Rays

1

Myliobatidee

Eagle Rays

1

Mobulida

Mantas, Sea Devils

1

Class Teleostomi: Bony Fishes

Anguillida

Murcenesocida

Echelider

Ophichthyid

Murænides

Elopida

Megalopidoe

Albulida

Clupeidoe

Engraulida

Synodontida

Prciliida

Belonido

Hemirhamphida
Common Eels

Pike-headed Eels

Worm Eels

Snake Eels

Moray Eels

Ten-pounders

Tarpons

Bone-fishes

Herrings

Anchovies

Lizard-fishes

Minnows, Killifish

Needle-fishes

Half-beaks
1

1

2

2

3

1

1

1

6

5

3

12

2

3 


\section{APPENDIX E}

Family Name

Exocetide

Aulostomido

Fistulariida

Syngnathidoe

Atherinida

Mugilide

Sphyronida

Polynemida

Holocentrida

Mullide

Scombrida

Trichiurida

Carangida

Coryphonida

Nomeida

Stromateida

Amiidor

Centropomida

Serranida

Lobotide

Priacanthide

Lutianidle

Hœmulidœ

Sparida

Gerrida

Kyphosida

Scianida

Cichlido

Pomacentrida

Labrido

Scarido

Ephippida

Chotodontida

Hepatida
Common Name

Flying-fish

Trumpet-fish

Cornet-fish

Sea-horses, Pipe-fish

Silversides

Mullets

Barracudas

Thread-fins

Squirrel-fishes

Surmullets

Mackerels

Cutlass-fishes

Cavallas

Number of

Species

Dolphins

Portuguese Man-of-War Fish 1

Harvest-fish

Cardinal-fishes

Snooks

5

2

2

3

1

6

2

5

1

15

1

1

1

3

3

Sea-basses

17

Triple-tails

Big-eyes

Snappers

Grunts

Porgies

Mojarras

Rudder-fishes

Croakers

Cichlids

Demoiselles

Wrasses

9

Parrot-fishes

16

Spade-fishes

1

Butterfly-fishes

6

Surgeon-fishes

4 


\section{APPENDIX E}

Family Name

Balistida

Monacanthida

Ostraciida

Tetraodontida:

Canthigasterida

Diodontidar

Seorperiida

Triglida

Cephalaeanthida

Gobiida

Echeneida

Malacanthido

Gobiesocide

Blennide

Bregmacerotida

Ophidiida

Pleuronectide

Antennariida

Ogcoeephalide

\author{
Conmon Name
}

Trigger-fishes

File-fishes

Trunk-fishes

Puffers

Sharp-nosed Puffers

Porcupine-fishes

Rock-fishes

Gurnards

Flying Gurnards

Gobies

Remoras, Sucking-fishes

Blanquillos

Cling-fishes

Blennies

Cusk Eels

Flounders, Soles

Sargassum-fishes

Sea-Bats

Total number of species
Number of Species

2

5

4

4

1

1

4

1

1

10

1

1

3

16

1

1

8

1

3

277 


\section{APPENDIX F}

THE LARVA OF THE EAST INDIAN TARPON, Megalops cyprinoides BROUSS.

(Translated from Bulletin du Department De l'Agriculture aux Indees Neerlandaises. Die Larve von Megalops cyprinoides Brouss. No. XX, 1908, pp. 10-12.)

In the month of January, fish larvæ appear in the brackish water of the harbor canals of Batavia, (see illustration) which are very similar to that of Albula, nevertheless it can not belong to this genus, but must be related to the Megalops cyprinoides, on later elucidated grounds. The total length of the larvæ collected by me varies from 23 to $30 \mathrm{~mm}$. yet all appear to be in the same stage of development. Older stages I have not yet found, and the development of the larvæ is unknown.

The body is band-like. One animal of $25 \mathrm{~mm}$. total length (22 without the caudal) has a depth of $3 \mathrm{~mm}$. It is quite transparent; in life only the eyes and swim bladder are distinct.

The fins, with the exception of the ventrals, are already well developed, and much larger than in the youngest of Gill's stages (Albula), which otherwise correspond most closely with the Batavia larvæ. Dorsal and anal fins lie far back, the first somewhat in front of, but for the most part over the latter. The dorsal has eighteen rays, and in front of these are plain evidences of one or more undeveloped rays; the last ray is somewhat larger than the others and this gives a hint of the filament of the adult Megalops. The anal fin possess twenty-seven rays, the caudal twenty, from each of which ten hypurales are formed. The small 



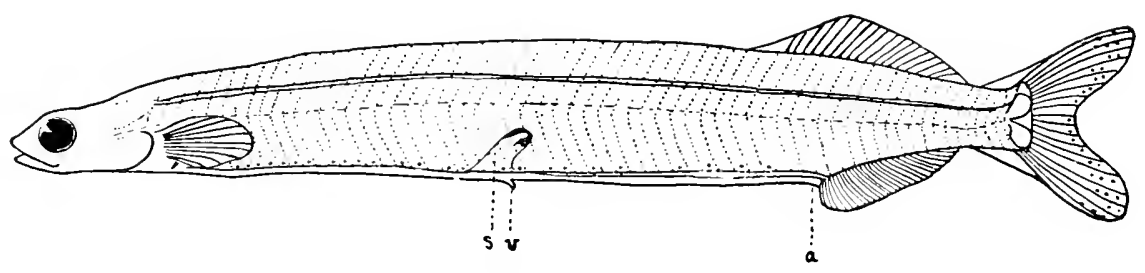

Leptocephalus Larva of East Indian Tarpon, Megalops cyprinoides, a, Vent; s, Swimbladder; v, Ventral Fins. (After van Kampen.) 


\section{APPENDIX F}

rim-rays of the tail fin are only visible in the first stage. 'The ventrals are the smallest of all, and lie in the middle of the body.

Of the inner organs the swim bladder is developed ahead of the rest. In life it appears as a small shimmering point. It lies above the ventrals.

There are about sixty-nine muscle bands evident, of which forty-eight or nine compose the body (between the ventrals and anus, 22), and twenty or twenty-one the tail.

On the ventral aspect of most of the nyomeres is a chromatophore. Besides these, small chromatophores lie along the upper and lower caudal rays, and along the posterior edge of this fin. Above the swim bladder lies a pigmented cap.

A methylen blue preparation of $30 \mathrm{~mm}$. larva, reveals the osseus beginnings of the cranium, the basal part of the pectorals and the fin-ray supports of all unpaired fins, but not yet of the vertebral column. The ray supports of the dorsal and anal fin rest upon two pieces of which the distal (basiostegal) is small and round.

The great number of rays of the anal fin makes it unlikely that the larvæ under consideration belongs to Albula conorhynchus, which possess only 9-10. In comparison the number agrees well with allied Megalops cyprinoides (anal rays 23-28), while in Elops saurus these are also much fewer (15-17). Other near related forms do not occur in the Archipelago. I dare assert with considerable assurance that this larva is that of some specimen of Megalops, especially as this genus is the only one which occurs commonly in the harbor canals of Batavia.

$$
\text { P. N. van Kampen. }
$$

As this volume was about to go to press the following article was printed in the Bulletin of the New York Zoölogical Society, Vol. XXXI, No. 2, March-April, 1928, page 54: 


\section{APPENDIX F \\ “TARPON IS VIVIPAROUS}

"Dr. C. H. Townsend, while on his way to the Galapagos Islands for the purpose of collecting the giant tortoises found on those islands, sends the following interesting note on the tarpon.

$$
\text { Balboa, Canal Zone, }
$$
March 30, 1928.

Dear Mr. Grant:

In conversation with Mr. S. A. Venable of the Zone Police Force, an experienced tarpon fisherman, I was informed that the fish is viviparous. He has repeatedly observed the females seeking shallow water, generally less than 4 feet deep, where a continuous stream of young fish was poured from her vent, the young being apparently little more than $1 / 4$-inch long. The young immediately seek refuge in groups, under the large scales of the mother, each scale standing outward at an angle of probably $30^{\circ}$. The young clustered in these scale shelters as thickly as they could. Mr. Venable's many observations lead him to believe that the young shelter under the scales ten days or more, when they are $3 / 4$-inch long. The mother soon rids herself of the young by shaking herself and by leaping.

I have myself no personal or book knowledge of the tarpon. The above notes may be a record of something entirely new, and may explain the remarkably large scales of this fish. If it isn't new to science, it is to many, including myself.

C. H. Townsend." 


\section{INDEX}

A

\author{
Abudefdufs, 24 \\ Ackazarpses, 197 \\ Albula rulpes, see ladyfish \\ Alpheus, see shrimps \\ Alutera, sce trigger-fish \\ ancestors, 35 \\ anchor, 49 \\ anchory, 92 \\ ancmones, sea, 54-57 \\ ant, queen, 12-13 \\ ants, 5.5, 102 \\ Aristotle, 116 \\ ascidians, 95 \\ Asteractis expansa, 58 \\ Atherina, see silversides \\ Auk, 187 \\ Aurclias, see jelly-fish \\ avalanche, under-water, 144 \\ a viators, 99 \\ Aticennia, see mangrove
}

\section{B}

Baerleker, 40

banding, bird, 195-196

barnacles, 95-96

barraruila, 146, 149, 158

basslets, $148-150$

beaches, 53

beaches, upland, 113

beetles, 112

birds, 80, 108, 184-197

Blackwood, Algernon, 8

boats, $13,50-52,109,184$

bombing, 16-19

Boyden. Lient. Hayne, 107

Bregmaceros, 93

bueket, water, 11

bumpers, $29,85-86$

butterflies, 112

\section{C}

Cabrite, 11

Cap Haitien, 106

Caranx latus, see jacks

carmine, 119

caves, $99-100$

ceiling, bay, 32-33

centaurs, 8-9

Centropomus undecimalis, see snook

Cephalacanthus volitans, see gurnard

chair, steamer, 187

chickadee, 192

Chiropsalmus, 29

Chloroscombrus ehrysurus, see bumpers

Christophe, 105, 106

Cichlasoma, 110

citadel, Christophe`s, 105, 106

coekroaeh, 52

color, 34-39, 189

Columbus, 75

conch, 51-52

copepods, 83

coral, $11,36,37,40,42,43,139$, $140,147,151,152,154$

Corixids, see water-boatmen

cotton, $46-48$

crabs, 24

erabs, fiddler, 52-53, 58-66

crabs, hermit, 54,64

crabs, sponge, 95, 96

erayfish, 16

Cretaceous, Upper, 98

rrickets, mole, 127

crocodile, 109

Crosby, Floyd, 69

crustacea, 83

ctenophores, 87

cuckoo, 50-52 


\section{INDEX}

cucumbers, sea, 54-56, 136-137

Cul-de-sac, 111

\section{D}

dance, voodoo, 9-10

demoiselle, 125, 145, 147, 149, 150 DH 202, 108

diving, 3-6, 29-32, 40, 94, 117, 118 , $123,134-136,157,161$

ducks, 67

Dunsany, Lord, 18, 105, 115

dynamite, $30,149,151$

\section{E}

earthquakes, 99

Easter, 20, 27

Echeneis, 153

eels, 16

eggs, chicken, 193

Eocene, Middle, 98

Eques, 153

Etang de Miragoane, 108

Etang Saumatre, 108, 109

Eucinostomus californiensis, 69

\section{F}

ferns, 112

fiddlers, see crab

fire, 112

fish, $17,19,27,29,30,78,84-86$, $125,137,152$

fish, butterfly, $42,43,147$

classification, 155-156

harvest, 30

lizard, 92

parrot, 42-43, 144-147, 150

pipe, 24

sargassum, 24, 26

squirrel, 125

surgeon, 41, 145, 157

trigger, 154,155

young, 91

fla mingos, 109

flock, 191

flowers, hummingbird, 172

flying, 99-108

Furcy, 112

\section{G}

gangway, $76,80,97$ gar, 24, 25, 109, 146

Garmannia, 127

Garrupa, 153

geese, barnacle, 21-22

Geiger, Major, 103-105

geologists, 98

geology, 98

gobies, 44, 109, 126, 127, 147

gorgonia, 42

Gramma, 148

grouper, 41, 153

guest annex, 7

Gurnard, 159-164

\section{H}

hæmulons, 157

IIalieutichthys, see sea-bat

Halla, Lieut., 184

helmet, $3,6,40$

heron, $51,62,67$

hermit, 179

herringlets, $27,30,31,32$

holothurians, see sea-cucumbers

hook, 149

hose, 48, 49

hummingbirds, 165-183

hydroids, 22, 44, 95, 137

\section{I}

Île de France, 146

illuminants, 76-78

iodine, 120

Isopora, 139

\section{$\mathrm{J}$}

jacks, 92, 93, 135, 153

Jamieson, Dr., 68, 69

jelly-fish, $5,29,47,80,81,82$, $84-87,89,134,135$

jelly-fish, thimble, $20-23$

Jenkinsia, see herringlets

Jewfish, 153

ladyfish, $9 \mathcal{2}$

\section{L}

lagoons, 67,70

lakes, 108

Lama, 111

Lamentin Bay, 16

Lamentin Reef, 134-158

Leptocephalids, 91, 92, 93 


\section{INDEX}

lichens, 176

Licutenant, $7,12-13,15,75,134$

lights, submarine, 78-80, 8z-84, $86,87,97,161$

Linuche unguiculata, see jellyfish, thimble

lizard-fish, 92

Lobotes, 24

\section{M}

Mendrina, 43

magic, 10

Manatees, Bay of, see Lamentin mangroves, $50,54,55$

migration, 194-196

millepores, 41, 139, 153

minnows, 109

Miocene, 98

Niragoane, Etang de, 108

mockingbird, 52

mojarros, 70

mountains, 99

Mosely, Prof., 163

moth, 173

\section{$\mathrm{N}$}

natives, 8-9, 51, 52

Nereis glandulata, 88, 90

nets, 78

nursery, 29

\section{o}

octopus, 36

owls, 113

\section{$\mathbf{P}$}

pelican, 27, 29, 30, 138

Petionville, 110

Phothornis r. ruber, 179

phospliorescence, 76

Phallinia nigra, 95

pios, 101

pines, 111

jipefish, 24

plankton, $21,59,78,81$

plantations, 100

polyps, 37, 44

Pritchard, Zarh, 38

Pseudoscarus, 145

Pterophryne, 26, 27

puffers, 24,25

\section{$\mathbf{Q}$}

Quads, see jelly-fish

Queen, 197

$\mathbf{R}$

reefs, 12, 16, 27, 35, 117, 138, 139

ripple-marks, 53

robins, 189

ruins, 11,107

Russell, Gen. John H., 7, 67, 184

Russell, Mrs., 7, 110

\section{$\mathrm{S}$}

St. Michel, 11, 99

Sand Cay, 15, 20, 26, 30

Sargassum-fish, 24, 26

Sargassum weed, 24, 25

Saumatre, Etang de, 108-109

scales, 192

schooner, see Lieutenant

sea-bat, 94

sea-cucumber, 136,137

sea-fans, 11

sea-horse, 155

sea-plumes, $4,38,43$

searchlight, 80

sea-urchins, 138,139

shadow, 44

shark, 134, 135

shark-bait, 135

shark, spotted, 40

shark-sucker, 153

shells, 18

shores, 50, 138

slirimps, 24, 125, 128-133

silica, 122, 123

silversides, $28-32$

snails, 53, 54, 98

snook, 69

Source Matelas, 67-70

sparrows, 188, 190

spiders, 176

Spirobranchus tricornis, 45

sponges, $15,46-49,73,116-129$, 132

squids, $25,26,47,48$

stallions, 110

Statue of Liberty, 80

Stichopus mobii, 137

sulphur springs, 68

sunbirds, 178 


\section{INDEX}

superstitions, 10

Syacium micrurum, see turbot Synodus fatens, see lizard fish

\section{$\mathbf{T}$}

Taj-Mahal, 44

Tamoya haplonema, 85

tarpon, 68-74, 146, 158

Tarpon atlanticus, see Tarpon

Tee-Van, John, 69, 152

Terrible, Mt., 107, 113

Thoreau, 178

Tibetans, 115

tourist, 185

tractrix, 42, 43

Trichocorixa reticulata, 68

triple-tails, 24

tunicates, 95, 96

turbot, 93,94

U

Uca mordax, 65

urchins, sea, 138, 139 voodoo dance, $9-10$

WV

warblers, 53

water-boatmen, 68-70, 73, 112

weed, 95

weed, Sargassum, 24, 25

Wetmore, Dr. Alexander, 49, 100

Wood, Commander V., 184

worms, 37, 44, 45, 84, 87-91, 143, 149,151

wrasse, $30,145,148,149$

Y

yellow-tail, 29

Z

Zoëa, 59, 60, 131 



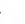



- 


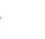




II) 